Historic, Archive Document

Do not assume content reflects current scientific knowledge, policies, or practices. 


\section{The KALLAY BROS COMPANY}

Painesville, Ohio.

Evergreen Jurseries

EVERGREENS - ORNAMENTAL TREESR I

SHRUBS and ROSES M.M.

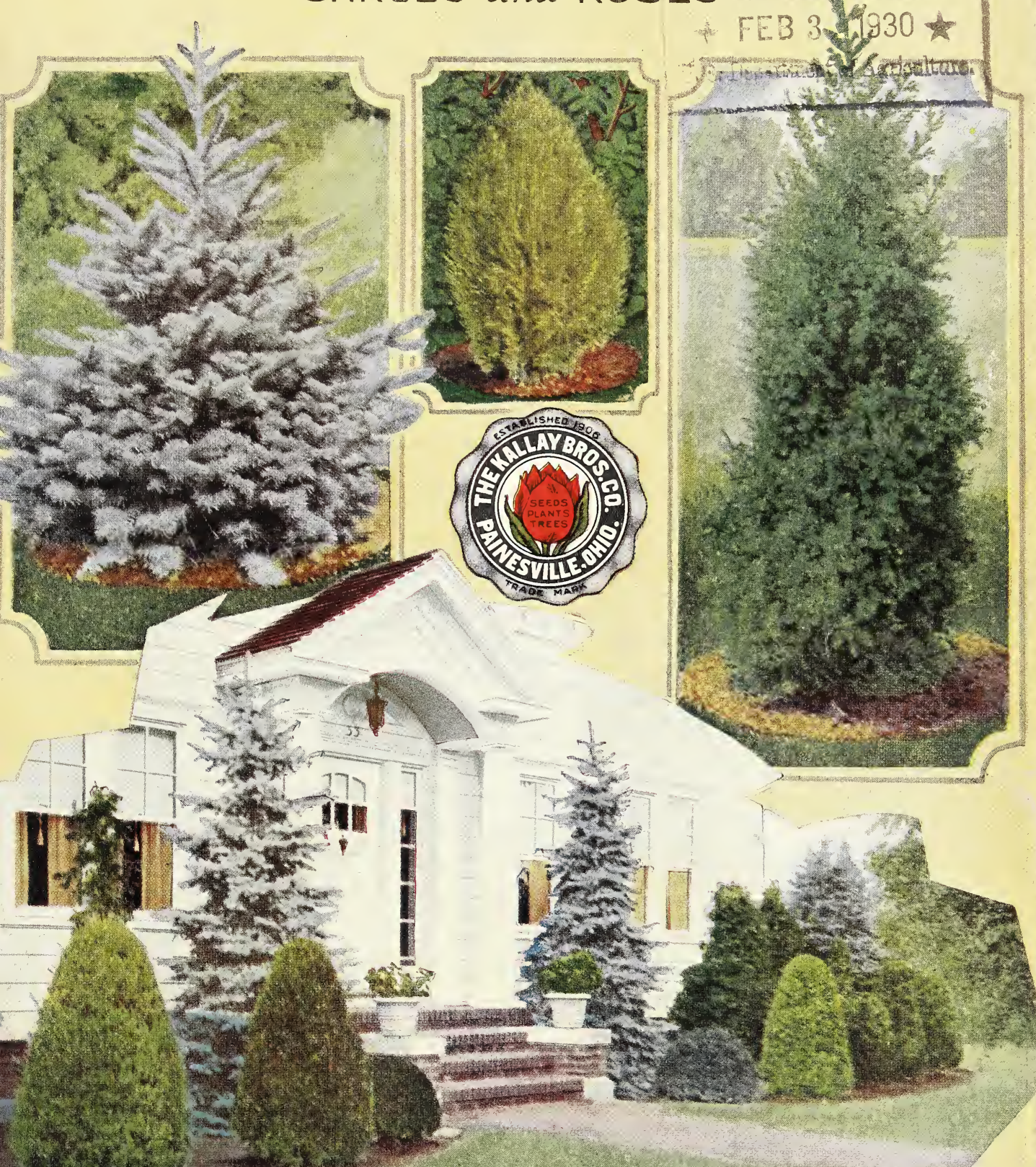



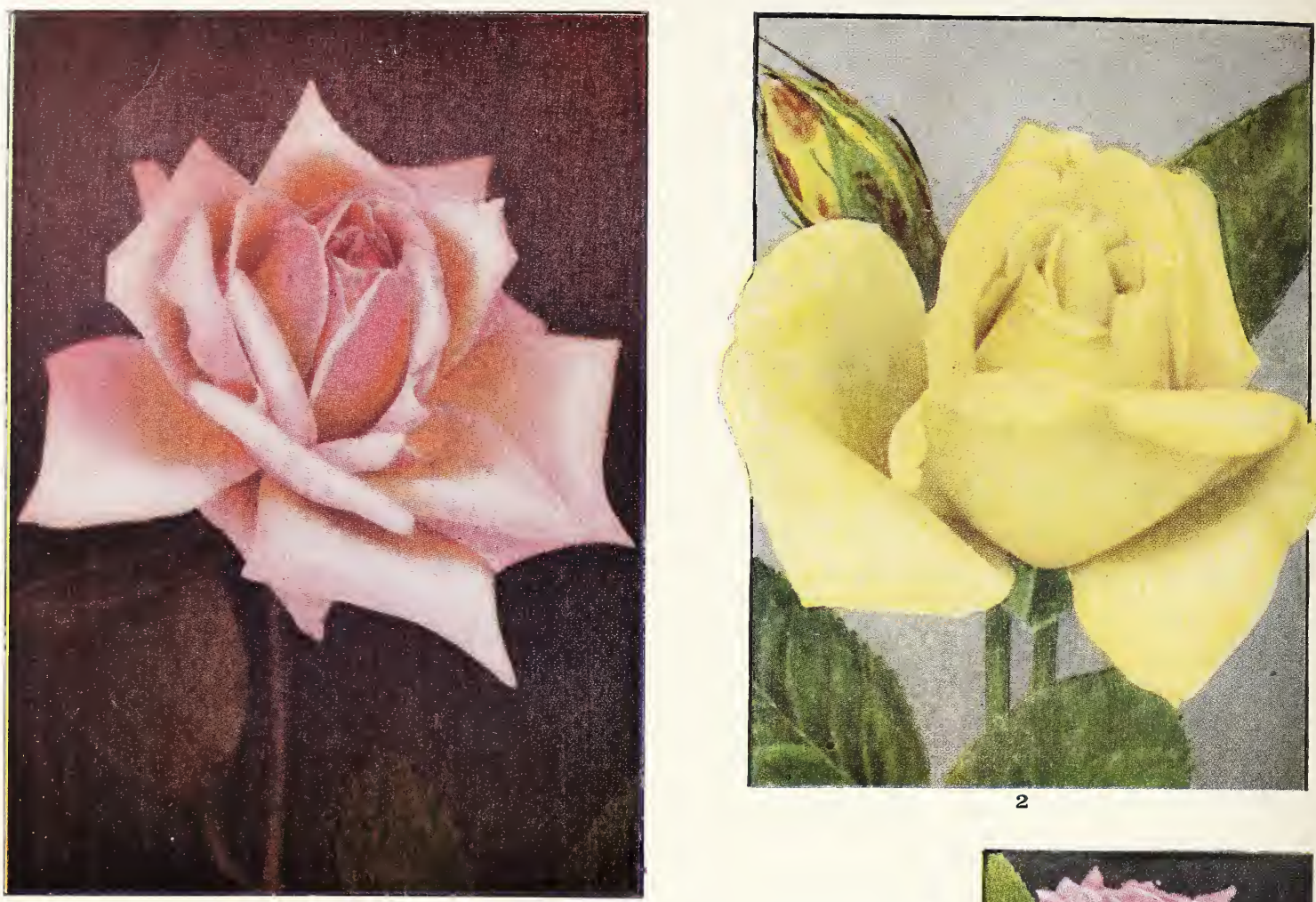

1

\section{Hybrid Tea Rose Collection}

I. Los Angeles ......... \$I.oo

2. Mrs. E. P. Thom ...... I. 25

3. Columbia .......... .90

4. Edel.............. I.Oo

5. Charles K. Douglas..... I.0O List Price........ $\overline{\$ 5.15}$
Five, distinct, choice varieties. One each of these five tea roses, 2 yrs. field grown stock, \$3.75
Postpaid.... $\$$.

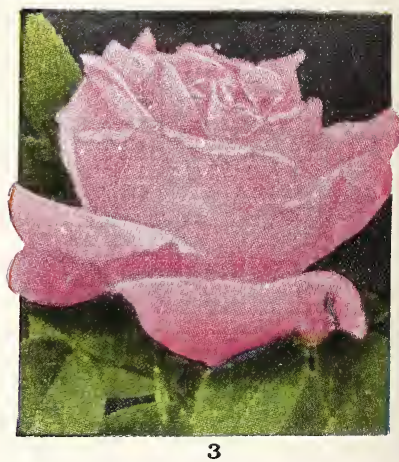

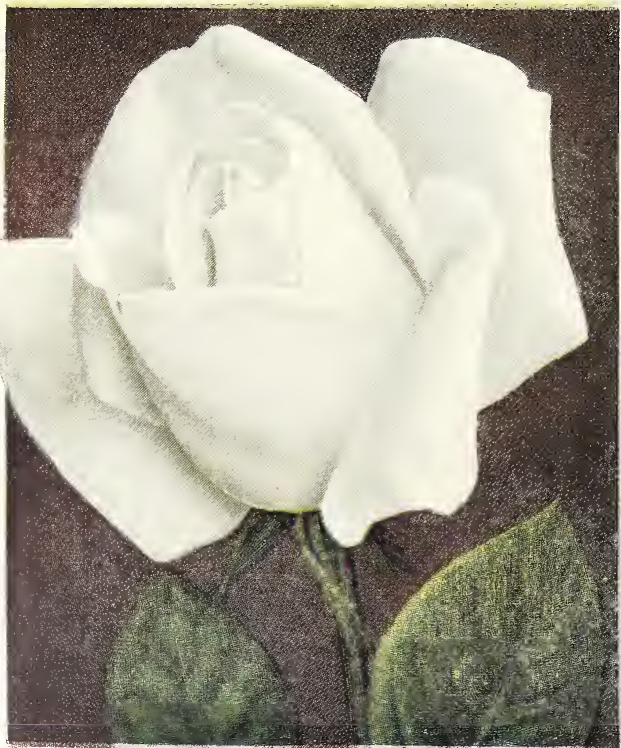

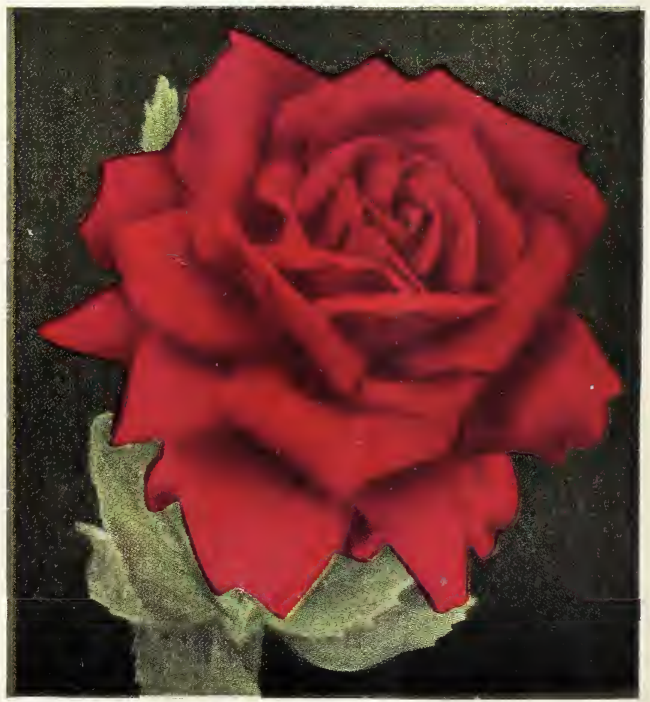




\section{To Our Friends and Customers}

In presenting our catalogue for the present year, we wish to express our thanks to the thousands of our customers for their generous patronage which we have enjoyed in the past, and assure them that we will use our best endeavors to merit the continu ance of their good will and orders in the years to come.

We thank you again sincerely for your confidence in us, and for your kind words of praise for our evergreens, trees, flowering shrubs and seeds, and we look forward with pleasure to again filling your orders this year.

\section{THE KALLAY BROS. CO.}

\section{General Directions to Customers}

LOCATION: Our offices and storage buildings are located on the corner of Madison Ave. and Bowhall Rd., on the South Ridge (State Route 84) one and one-half miles east of Painesville. West bound traffic on State Route 84 passes in front of our office. East bound trafic can easily reach our location by passing through Main Street in Painesville and continuing east one and one-half miles. Those interested in the landscape art and the beauty of trees and plants out-of-doors are always cordially welcome at our nurseries. Excellent highways throughout the State of Ohio will enable you to reach us on paved roads. Our complete stock of evergreens of all sizes and variety, ornamen. tal trees, shrubs, roses and fruit trees and vegetable seeds will enable us to fill the order complete of a most exacting customer.

WHEN TO ORDER: Just as soon as this catalogue is received, look over its contents, make up your order and send it in. We can always give your orders more of our personal attention if received early in the season and before the rush of the spring trade. Use the enclosed order sheet, and write as plainly as possible, as it will help us to avoid mistakes in filling your order.

TERMS: Our terms are strictly cash with order, and no C. O. D. shipments are made unless the purchaser remits in advance at least one-third of the full value of the order. Remittance may be made either by Postal or Express money orders, bank drafts, personal checks, bil's enclosed in registered letters, and by stamps of small denomination for orders less than $\$ 1.00$.

PARCEL POST SHIPMENTS: You will note through out the catalogue that we are offering seeds, roots, bulbs and small plants by mail as well as express. If the size of the plant permits, we ship by parcel post, charges prepaid by us. The transportation charges on all express and freight shipments are paid by the purchaser upon arrival of the order. We also make deliveries by truck to any point in Ohio, lower Michigan and Western Pennsylvania, where the size of the order justifies delivery by truck, in which case the amount agreed upon will be charged for the delivery.

EXPRESS AND FREIGHT SHIPMENTS: We recommend that all orders of a bulky nature be shipped either by express or freight, in which case we can pack the orders more securely, and the stock will reach you in a better condition. On larger evergreen orders, which are lifted with large balls of earth and burlaped, we suggest freight shipment.

OUR GUARANTEE: We guarantee all shipments of seeds, bulbs, plants and implements to reach the purchaser in good condition when shipped by parcel post or express. We shall cheerfully replace any plant or seed damaged in transit when so shipped.

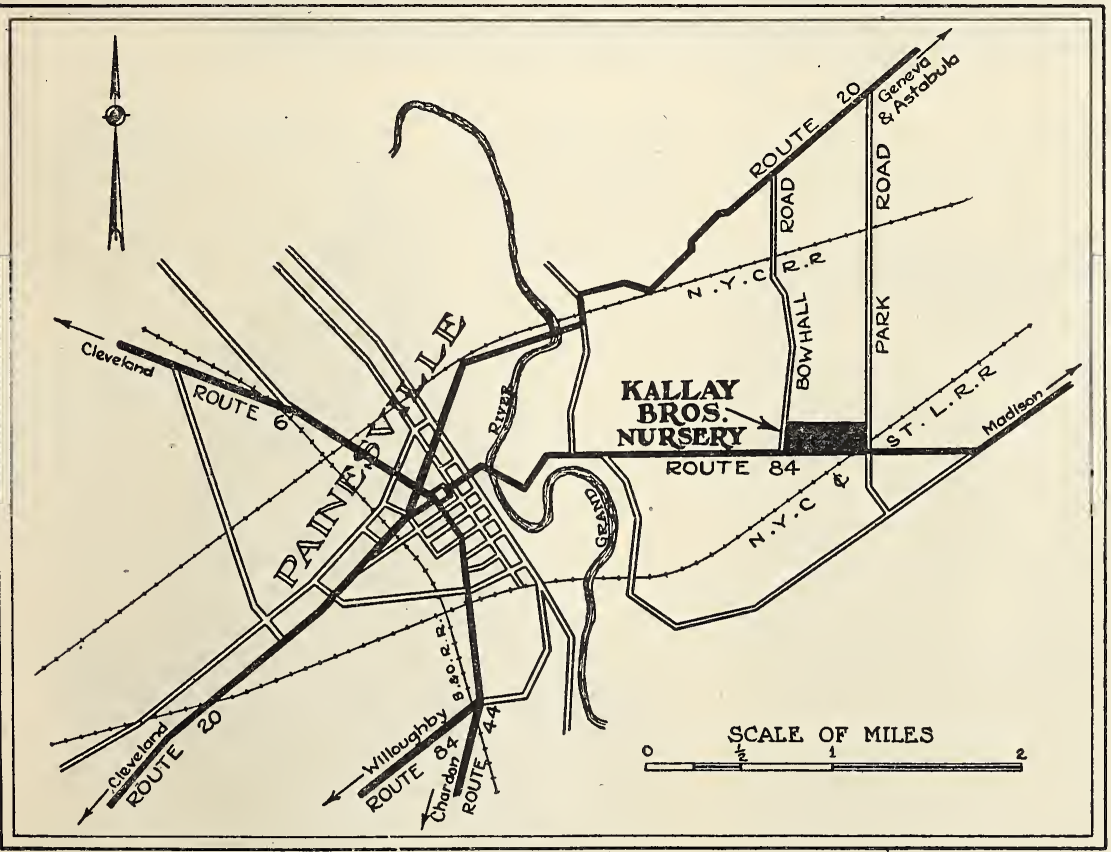

NON - WARRANTY: Most of the failures with seeds, plants and bulbs are due to causes entirely beyond our control, such as unfav. orable weather or soil conditions, too deep or too shallow planting, etc., which renders it impossible for us to guarantee success, and although we take all possible care to supply only such goods as will, under proper conditions, produce satisfactory results, we still give no warranty as to description, quality or productiveness of any of the seeds, plants, trees or bulbs we send out, and will not be in any way responsible for $t h$ e crop, and every order for articles named in this catalogue will be executed on these conditions only. It must, however, be plain to every one who gives the matter the slightest thought that it is to our best interest to send out only such stock as will not only grow, but prove true to the name and description.

ADDRESS: Address all letters and communications, and make all money orders, checks and drafts payable to THE KALLAY BROTHERS CO., Painesville, Ohio 


\section{EVERGREEN TREES}

In common with our other American activities we demand no less speed in the construction of our gardens and the grounds which surround our new homes than in our business and building operations.

There is a natural pride and desire to make the grounds about one's home in keeping in appearance with the fine interior decorations and furnishings of the house, and a consideration of special importance is the actual monetary value added to a property so quickly by good planting. To produce this result, we must resort to the stately and interesting everg een trees, besides deciduous trees and shrubs.

The beauty of deciduous trees and shrubs is wrought in stately lines of trunk and arching branch, of opening bud, gay flower and cool green of spreading leaf. These aptly suit the spirit of our changing seasons, while through nature's shifting scenery from white of winter snow and flowered spring to bronzing autumn the Evergreens sound a pleasant note of contrast in form and color among their deciduous neighbors. Varying in form from spreading Yews and Junipers to Columnar Cedar, they are especially appropriate in planting close to the house an 1 garden, giving a proper setting to the architectural design and lending warmth of color to the winter scene.

Being limited in space, we shall list herein the prices of the most popular size evergreens. We have many thousands of smaller and larger trees, prices on which will be quoted upon application.

All our evergreen trees are lifted with large, solid and compact balls of earth and burlaped before shipment.

\section{CONIFEROUS EVERGREENS}

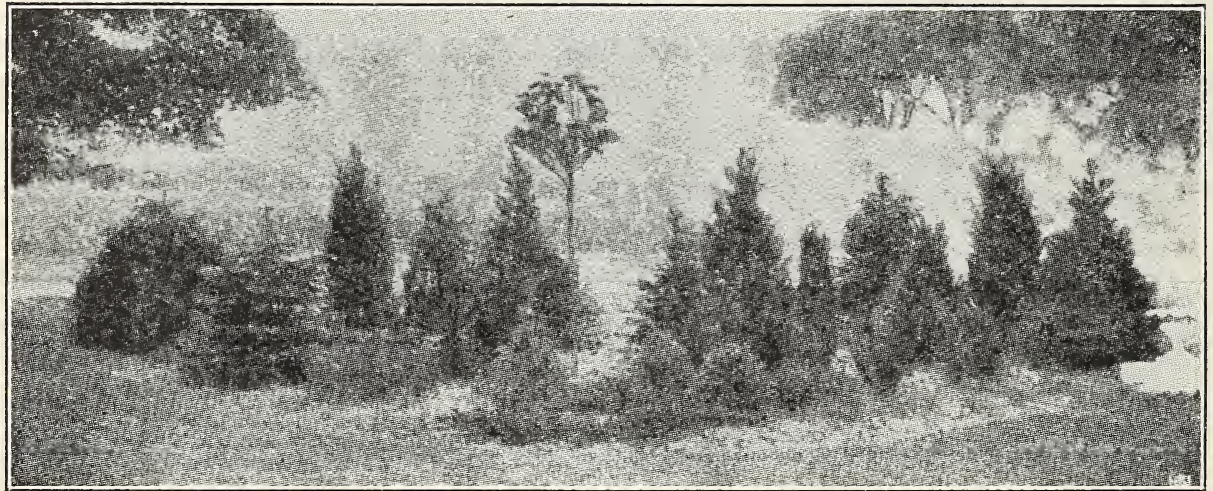

The owner of the bed of evergreen $s$ ho $w n$ here $u s$ ed to spend half the price of the evergreens each year in bedding plants and perennials-now he avoids replacing and expensive upkeep and enjoys the yearround beauty of evergreens.

\section{Abies}

Douglasii. Douglas Fir; a Colorado species. Forms a large spreading pyranid of light green foliage; much more feathery in effect than most evergreens. $18-24$ in. $\$ 3.00,10$ for $\$ 27.50 ; 2-3 \mathrm{ft}$. $\$ 4.50,10$ for $\$ 42.25$.

\section{Juniperus}

J. Communis Canadensis. Canadian Juniper. A dwarf juniper of bushy upright growth. Foliage is brownish green, resembling in general appearance juniperus communis, but the latter is of more spreading habit of growth. 15-18 in. $\$ 2.50$, 10 for $\$ 22.50$.

J. Communis Depressa Aurea. Golden Canadian Juniper. The foliage is beautifully tipped with golden color. Distinct and attractive. 15-18 in. $\$ 3.00,10$ for $\$ 27.50$.

J. Communis Hibernica. Irish Juniper. Erect, slender and formal in habit; foliage sage green, very compact; making a splendid column, sometimes 15 to 20 feet high; much used in cemeteries. $18-24$ in. $\$ 1.75,10$ for $\$ 15.00 ; 2-3 \mathrm{ft}$. $\$ 2.50,10$ for $\$ 22.50$.

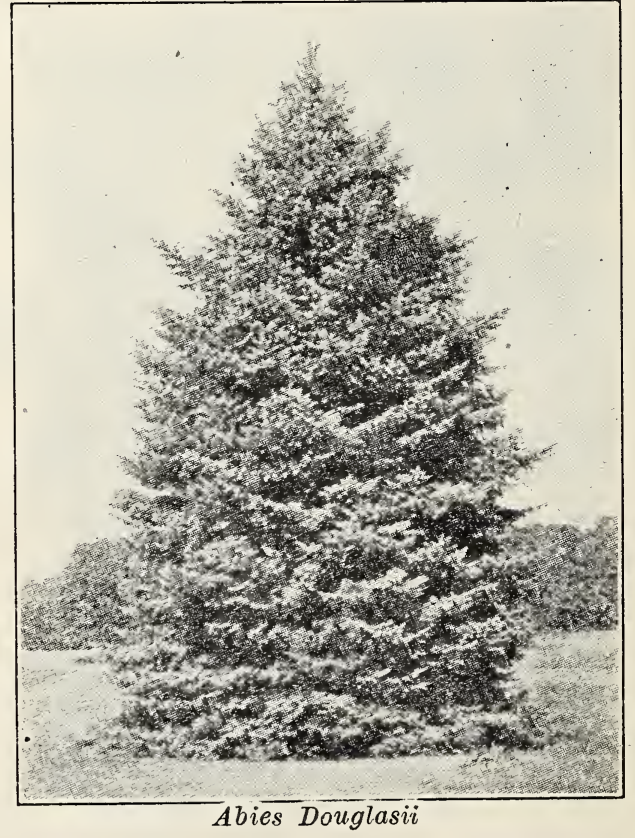




\section{Juniperus (continued)}

J. Communis Suecica, (Sweedish Juniper). Narrow, Columnar form, with lighter, more blueish foliage than the Irish Juniper. Branchlets droop at the tip. $18-24$ in. ea. $\$ 2.00 ; 10$ for $\$ 17.50 ; 2-3 \mathrm{ft}$. ea. $\$ 3.25 ; 10$ for $\$ 30.00$.

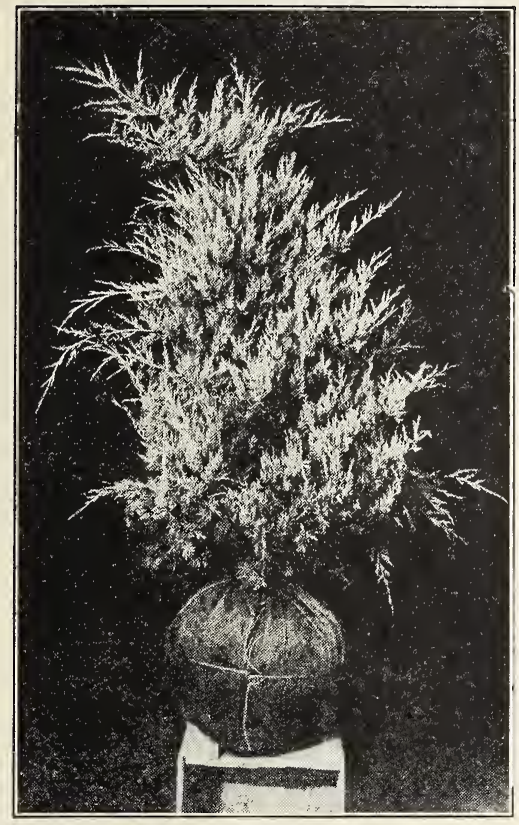

Jun. Virg: Glauca (Blue Cedar)

J. Chinensis Pfitzeriana (Pntzer Juniper). Vase shaped, spreading growth, and light bluish green foliage producing a beautiful soft effect. Extremely hardy. Tolerant of eity conditions and partial shade. Excellent for foundation plantings. 18-24 in., each $\$ 3.50 ; 10$ for $\$ 32.50 ; 2-3 \mathrm{ft}$., each $\$ 4.50 ; 10$ for $\$ 42.50$.

J. Chinensis Procumbens (Trailing Juniper) Dark green foliage, low, spreading habit. For use in rock gardens and as a ground cover on banks or terraces, in which latter place it should be planted in colonies. $15-18$ in. ea. $\$ 2.75 ; 10$ for $\$ 25.00$.

J. Chinensis Globosa (Globe Chinese Juniper). Very low growing; use in masses in low border planting. $18-24$ in. ea. $\$ 3.00 ; 10$ for $\$ 27.50$.

J. Chinensis Sargentii (Sargent Juniper) This is an interesting creeping variety, slightly resembling Juniperus Chinensis Procumbens. It was first collected by Prof. Sargent of the Arnold Arboretum, in Japan in the Autumn of 1892. It forms a low dense mat with wide-spreading branches, covered with small, dark green, scale-like leaves. Some trees have a decided bluish cast. 15-18 in. ea. $\$ 2.50$; 10 for $\$ 22.25$.

J. Chinensis Stricta (Spiney Greek Juniper). A chinensis variety with peculiar, conspicuous blue green shade of color. Dwarf very dense, cone shaped; slow growing and useful in foundation plantings. $18-24$ in. ea. $\$ 3.00 ; 10$ for $\$ 27.50$.
J. Sabina (Savin Juniper). Handsome mossgreen foliage; adapted to use as a filler in evergreen groups, or as' a dwarf ground cover. 18-24 in. ea. $\$ 3.25 ; 10$ for $\$ 30.00$.

J. Sabina Tamariscifolia (Tamarix Leaved Juniper.) A beautiful trailing form of Savin, with bluish green foliage. 'The construction is dense and very fine, like the tamarix foliage; especially attractive, when showing new growth. 15-18 in. ea. $\$ 3.25 ; 10$ for $\$ 30.00$.

J. Communis, Horizontalis (Waukegan Juniper) (Sabina Prostrata). Valuable for ground covering in exposed sandy or rocky location. Usually low, with long trailing branches and numerous short, upright branchlets. 18-24 in. ea. \$2.25; 10 for $\$ 20.00$.

J. Virginiana (Red Cedar). Of dense, broadly columnar habit. Is always popular and can be used ornamentally in a number of ways, thriving well and making a fine appearance in soils or situations where other trees will not grow. 18-24 in. ea. $\$ 2.00 ; 10$ for $\$ 17.50 ; 2-3$ ft. ea $\$ 3.25 ; 10$ for $\$ 30.00$.

J. Virginiana Glauca (Blue Virginia Cedar). Formal slender type, with foliage of a distinctly bluish color. Well suited for accents and for foliage contrasts. $18-24$ in. ea. $\$ 3.50 ; 10$ for $\$ 32.50 ; 2-3$ ft. ea. $\$ 4.25 ; 10$ for $\$ 40.00$.

J. Virginiana Cannarti (Cannart Red Cedar). This is a pyramidal compact grower, of medium size, reaching 15 to 20 feet. With only a few moments trimming each spring, it ean be kept at any size wanted; it has rich, green heavy tufted foliage. 18.24 in. ea. $\$ 3.50 ; 10$ for $\$ 32.50 ; 2-3$ ft. ea. $\$ 4.25 ; 10$ for $\$ 40.00$.

J. Virginiana Schottii (Schott Red Cedar). Its general appearance is like Juniperus Cannartii, but is distinguished by its bright, rather yellowish green foliage; very hardy, growing 15 to 20 feet, and stands almost any amount of trimming. 18-24 in. ea. $\$ 3.50 ; 10$ for $\$ 32.50 ; 2-3$ ft. ea. $\$ 4.25 ; 10$ for $\$ 40.00$.

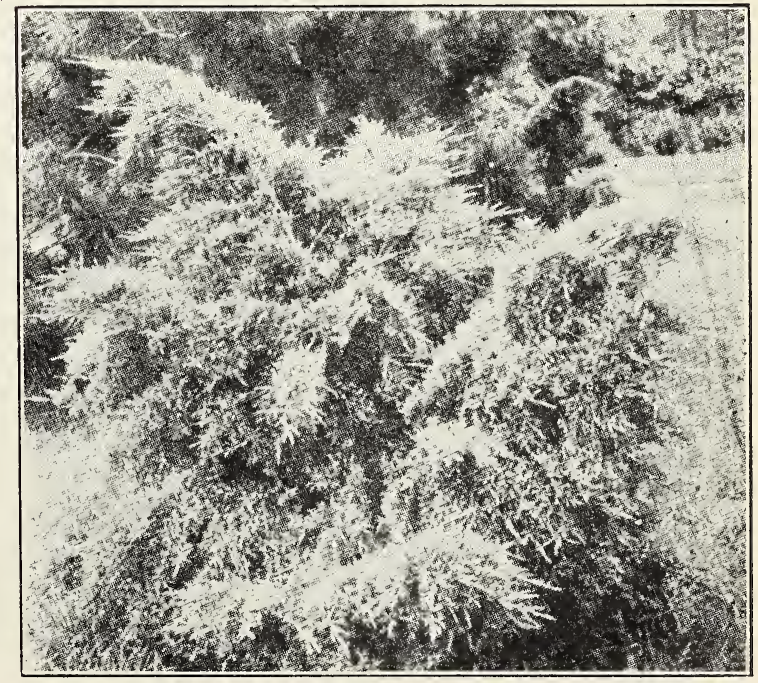

Juniperu Chinensis Pfitzariana 


\section{Juniperus (continued)}

J. Virginalis Globosa. (Globe Virginiana Juniper.) Perfectly round, very dense in growth with many short branchlets covered with soft foliage of light green, dark green and gold. Excellent for planting among perennials, in rock gardens, Japanese gardens, and in situations requiring evergreen that will remain small. 18 to 24 inches, each $\$ 3.00 ; 10$ for $\$ 27.50$.

J. Virginiana Elegantissima Lee. (Lee's Golden Juniper.) Here is a tree that will give variation to the green and blue color of other evergreens. It is rather broad and bushy with slightly drooping, rich, creamy golden foliage. Unless kept low by trimming, it will grow 10 to 15 feet high. Likes a fairly sunny location. 18 to 24 inches, each $\$ 3.75 ; 10$ for $\$ 35.00$; 2 to 3 feet each $\$ 4.75$; 10 for $\$ 45.00$.

\section{Picea-Spruce}

Canadensis (alba). (White Spruce.) One of the very best conifers, especially for cold climates. Compact, upright-growing, long-lived, retaining its branches to the ground, aromatic, drought-resisting; varies in color from light green to glaucous blue. 18 to 24 inches each $\$ 2.50 ; 10$ for $\$ 22.50$; 2 to 3 feet each $\$ 3.50 ; 10$ for $\$ 32.50$.

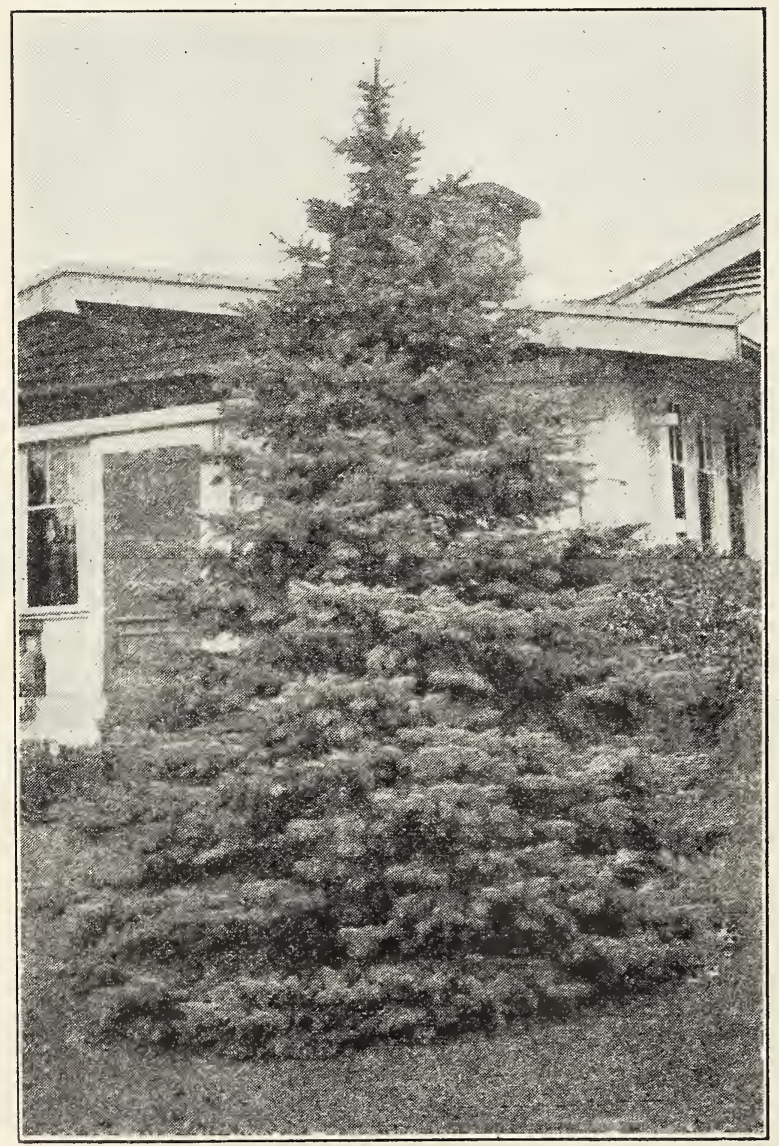

Spruce Colorado Blue

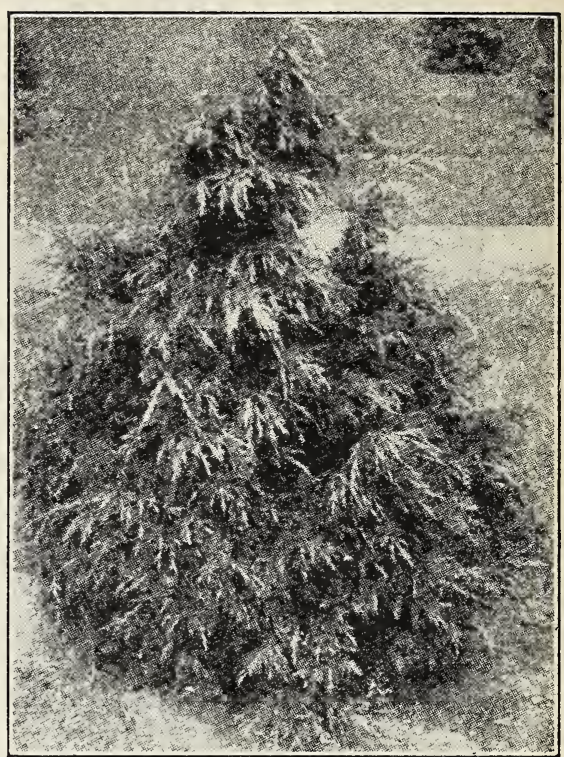

Lee's Golden Juniper

Canadensis. (Black Hill Spruce.) The Black Hill Spruce is the hardiest of all spruces, symmetrical, compact and bushy in habit of growth; in fact, the very smallest trees soon form round, sturdy, compact bodies. The foliage varies from green, to bluish tint, and all trees are remarkable for their bright, fresh color. 18 to 24 inches each $\$ 2.50 ; 10$ for $\$ 22.50 ; 2$ to 3 feet $\$ 3.50$; 10 for $\$ 32.50$.

Excelsa. The Norway Spruce and its many uses are well known. It is planted for hedges, shelter-belts, screens, backgrounds, etc., in large quantities every year. It has a naturally fine gothic form, and grows fast. 18 to 24 inches, each $\$ 1.50 ; 10$ for $\$ 12.50 ; 2$ to 3 feet, each $\$ 2.25 ; 10$ for $\$ 20.00$.

Colorado (Pungens.) The origin of the famous Blue Spruce. Vigorous grower and hardy, making fine specimens in a broad based, sharply defined pyramid form; foliage rigidly angular with sharp needles very densely set. Light green color. 18 to 24 inches each $\$ 3.25 ; 10$ for $\$ 30.00 ; 2$ to 3 feet each $\$ 4.50 ; 10$ for $\$ 42.50$.

Colorado Blue. (Pungens Glauca.) A selected blue shade, from foregoing. This is one of the showiest and most impressive evergreens, surpassed only by the grafted Koster's Blue Spruce -which is temporarily unobtainable. 18 to 24 inches each $\$ 6.50 ; 2$ to 3 feet each $\$ 8.00$.

Pungens Kosteri (Koster's Blue Spruce). The best of the Blue Spruces. Foliage is silvery blue, densely crowded on the many branches. We have paid particular attention to getting the absolutely true stock of this famous tree and can guarantee its true blue color and character. Supply is very limited. 18 to 24 inches each $\$ 13$; 10 for $\$ 120.00$. 


\section{Pinus-Pine}

Nigra austriaca. (Austrian Pine). One of the best foreign species for this country. Its growth, even when young, is characteristically stout and sturdy. A remarkably robust, hardy, spreading tree of grand size; dark and massive in effect. 18 to 24 inches, each $\$ 2.50 ; 2$ to 3 feet, each $\$ 3.50$.

Montana Mughus. (Dwarf Mugho Pine.) A unique Alpine species, broader than its height and sometimes almost prostrate, forming a dark, dome-shaped bush. 12 to 15 inch, each $\$ 2.75$.

Sylvestris. (Scotch Pine.) Dense, broadly pyramidal, luxuriant in growth, with strong shoots and silvery needles. 18 to 24 inches, each $\$ 2.25 ; 2$ to 3 feet, each $\$ 3.25$.

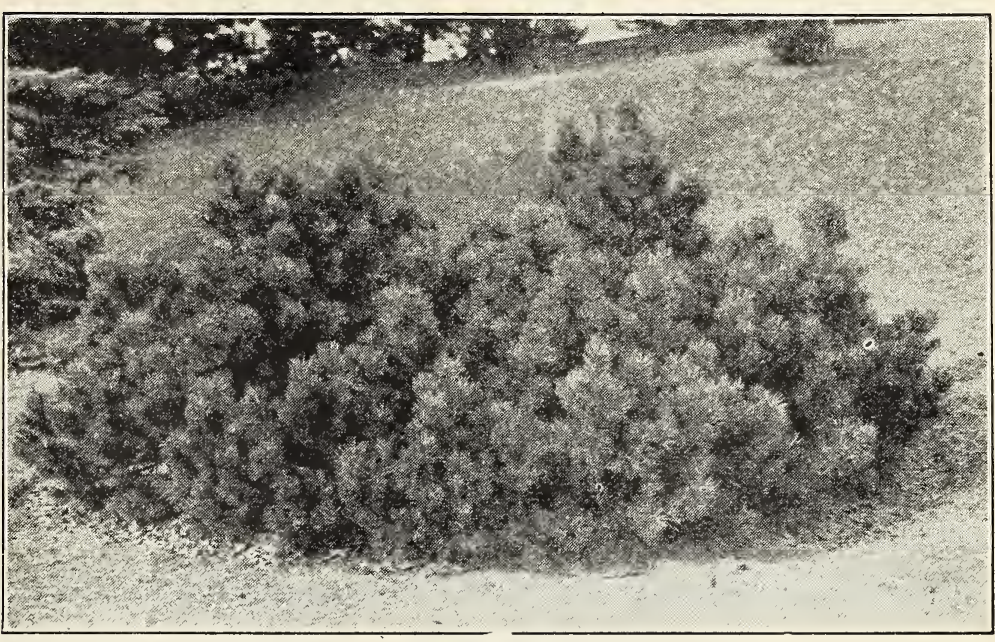

Mugho Pine

Filifera Aurea. Same form and habit as aforesaid. Foliage bright golden yellow. 15 to 18 inches, each $\$ 3.75$.

Obtusa Gracilis Aurea. A graceful small tree, the

Strobus. (White or Weymouth Pine.) Tall, stately, and most beautiful of all our native pines. It is also among the quickest-growing, longest-lived, and most generally useful. The needles are silvery blue, and plumy in effect. 18 to 24 inches, each \$2.25; 2 to 3 feet, each $\$ 3.25$.

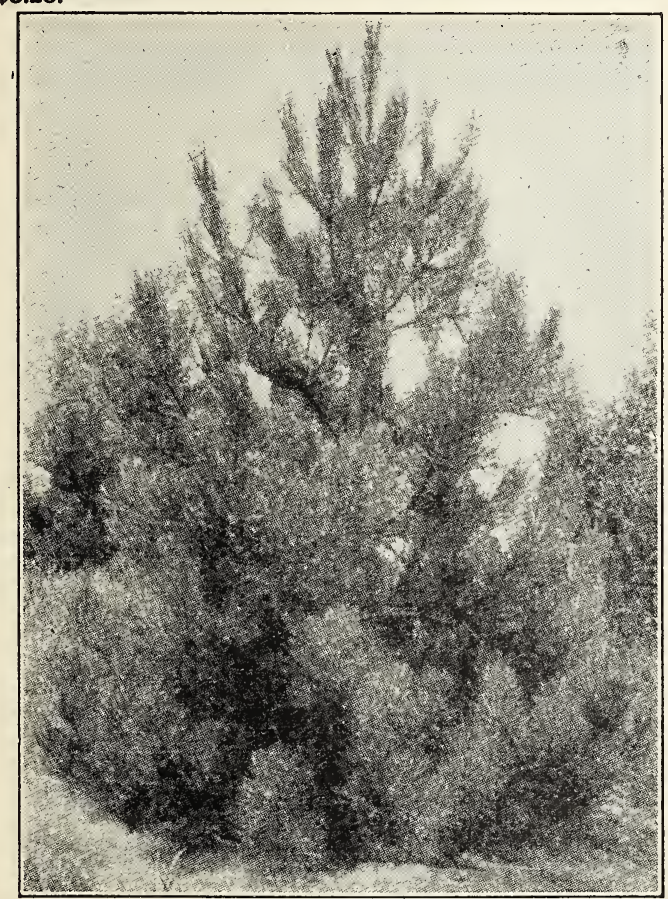

Scotch Pine

\section{RETINOSPORA}

Filifera. The leading shoot grows upright, the branches are nearly horizontal, with long, drooping, tasseled ends. Pyramidal in outline; bright green. 18 to 24 inches, each $\$ 3.00 ; 2$ to 3 feet, each $\$ 3.75$. fern-like young shoots of a fine golden color, 2 to 3 feet, each $\$ 4.00$.

Obtusa Grippsii Gracilis. A beautiful golden form of Japan Cypress, carrying its bright golden color well through the season. 18 to 24 inches, each $\$ 3.00$.

Obtusa Nana Compacta. One of the finest of the fam. ily in showy arrangements of foliage, very dwarf, dense, slow growing habit, and great depth of color. 12 to 15 inches, each $\$ 2.75$.

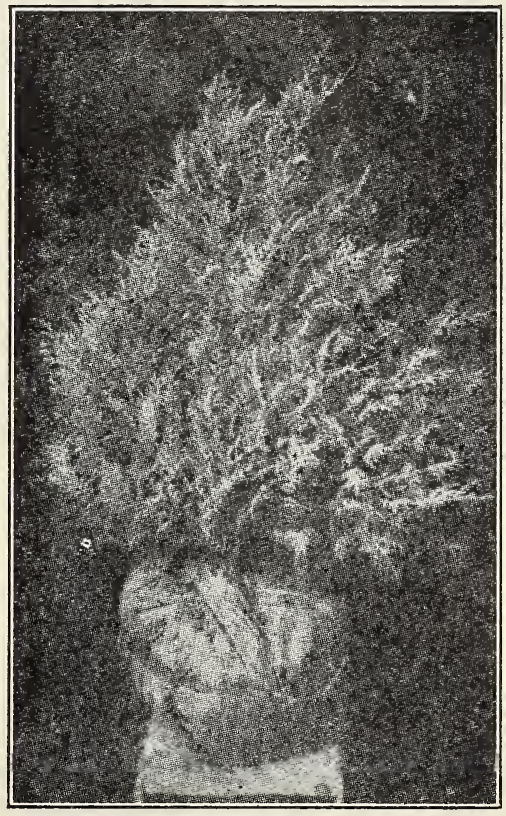

Ret. Plumosa Aurea

Plumosa Aurea. One of the hardiest. The rich golden growth of spring holds well through the summer. One of the best for specimens or hedges. 18 to 24 inches, each \$2.75; 2 to 3 feet, each $\$ 3.75$. 
Plumosa. An exceedingly handsome, acorn-shaped evergreen of medium tall growth, from Japan, with feathery, light green foliage. 18 to 24 inches, each $\$ 2.75 ; 2$ to 3 feet, each $\$ 3.75$.

Pisifera. Open and tall in growth, with erect branches pendulous at tips; foliage feathery, light green, glaucous beneath. 18 to 24 inches, each $\$ 2.75 ; 2$ to 3 feet, each $\$ 4.00$.
Pisifera Aurea. A bright golden form holding its color. Its habit runs to bushiness; an ideal type for corners, against dark brick. 18 to 24 inches, each $\$ 2.75 ; 2$ to 3 feet, each $\$ 4.00$.

Squarrosa Veitchii. Dense growth; soft, beautiful silvery blue foliage arranged in spirals, which gives the impression of boiling over. Shows to best advantage close to dark greens. 18 to 24 inches, each $\$ 2.75 ; 2$ to 3 feet, each $\$ 3.50$.

\section{Taxus - The Yews}

American Yew

(Taxus

Canadensis).

Don't forget

the Yew

for $a$

shady corner

-it will do

well there.

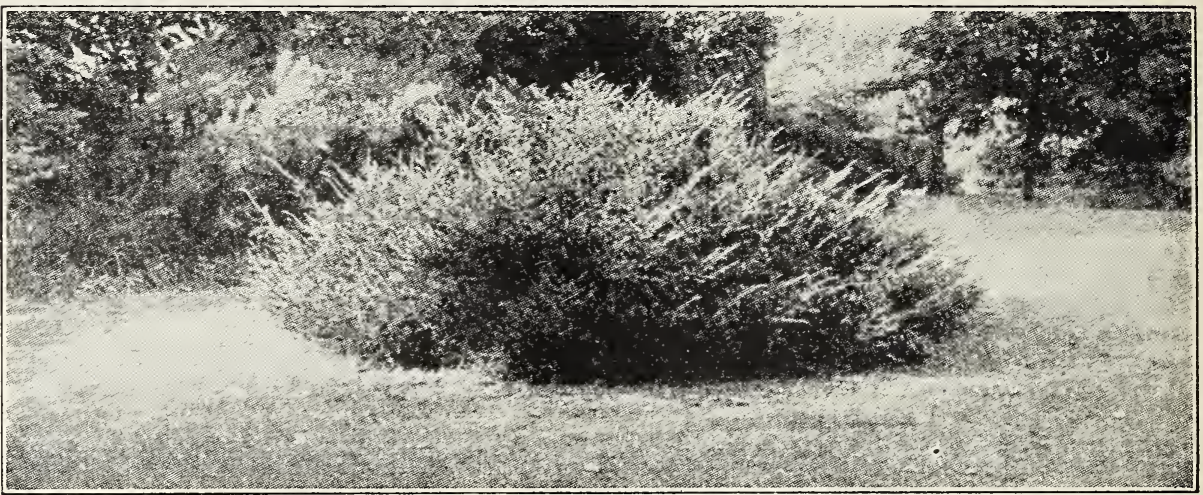

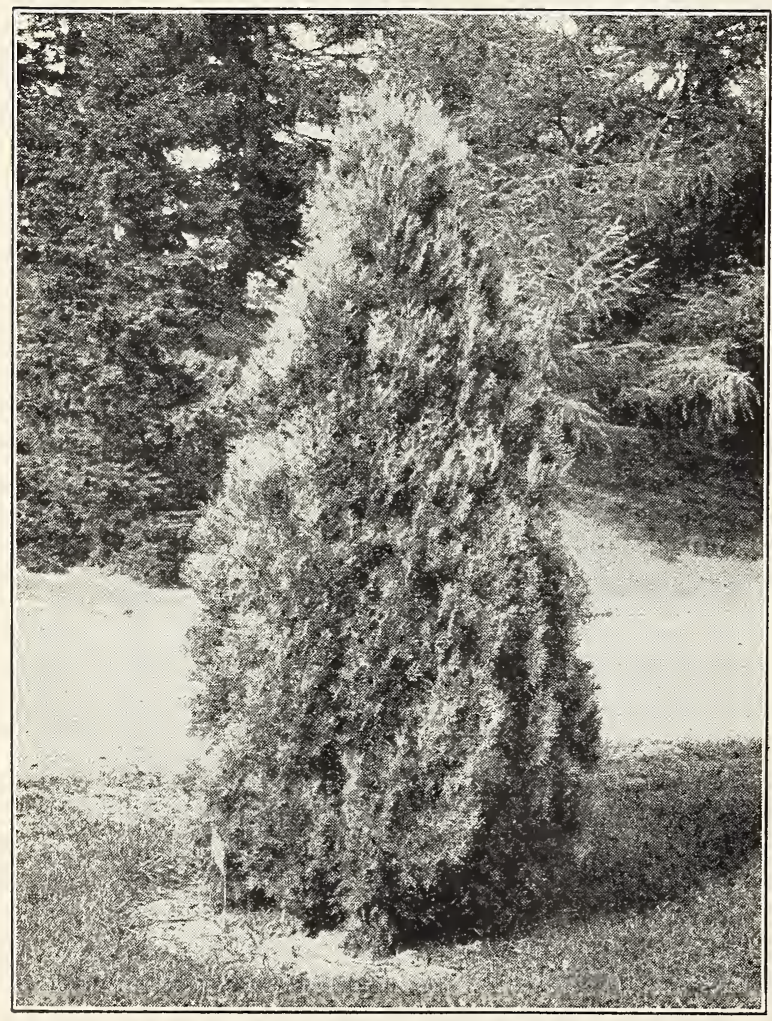

Thuya (Biota) Orientalis
Canadensis. (American Yew.) A valuable, hardy dwarf evergreen, seldom growing more than 2 to feet above the ground. The drooping branches are densely clothed with dark green fol age which assumes a reddish tint in the winter. The variety thrives well in shade and can be 1 rimmed to any desirable shape. 15 to 18 inches, each $\$ 3.00$.

Baccata Repandens. (Spreading English Yew.) Exceedingly rich in foliage, this dwarf type is of most pleasing character, and masses well with other evergreens. As a low hedge it has no superior. For fronting the evergreen border it is just right. 12 to 15 inches, each $\$ 3.00$.

Cuspidata Brevifolia. (Dwarf Japanese Yew.) A handsome Japan Yew, with short, rich, dark green leaves; dense bushy habit. Hardiest of the yews, and one of the best compact dwarf evergreens for edging and foreground. The branches are covered with little bunches of dark green foliage which retains the rich color entirely throughout the winter, thus adding to its many other points of superiority, and making it one of the most valuable yews. 15 to 18 inches, each $\$ 3.50$.

\section{THUYA ORIENTALIS The Chinese Arborvitaes (Biotas)}

Delicately cut foliage, arranged in parallel, perpendicular fronds distinguish these arborvitae from the American varieties, which they closely resemble. They are useful in foundation and group plantings and for producing formal effects.

Thuya (Biota) Orientalis. Chinese Arborvi'ae (S). Columnar habit with light green foliage arranged in perpendicular fronds. Grows rapidly and is useful for group and formal plantings. 18 to 24 inches, each $\$ 2.50 ; 2$ to 3 feet, each $\$ \mathbf{3 . 5 0}$.

Berkman's Golden-Compacta. Compact and bushy rich golden-tipped foliage. A very beautiful evergreen whose slow growth permits many uses. Foliage is very close, making it very compact. This makes a good specimen subject as well as an at ractive evergreen for grouping. No pruning required. 12 to 15 inches, each $\$ 2.50 ; 15$ to 18 inches, each $\$ 3.00$. 
Thuya-Arborvitea. The arborviteas vary greatly in habit and color. They bear transplanting and pruning well and have many uses, especially in formal gardens. They are also well suited for bedding with other evergreens, for hedges, screens, shelter-belts and house decorations. All are neat and symmetrical in habit, dense, with flattened, frond-like leaves.

Arborvitae (American). The plant is, all things considered, the finest evergreen for hedges. It is very hardy and easily transplanted, few plants failing if properly handled. It grows rapidly and with little care, or rather by easy management, it soon forms a most beautiful hedge, very dense and perfectly pleasing to the eye. It forms a most desirable and ornamental screen to divide the lawn from other grounds, 18 to 24 inches, each $\$ 1.50 ; 10$ for $\$ 13.50$, 2 to 3 feet, each $\$ 2.50 ; 10$ for $\$ 22.50 ; 3$ to 4 feet. each $\$ 3.50 ; 10$ for $\$ 32.50 ; 4$ to 5 feet, each $\$ 5.00$; 10 for $\$ 45.00$.

Occidentalis Compacta. Dwarf, rounded, dense; with leaves of light grayish green. 15 to 18 inches, each \$2.75; 18 to 24 inches, each $\$ 3.75$.

Douglas Golden. One of the hardiest of all golden evergreens. Broad and bushy growth with long slender branches and bright yellow foliage. 18 to 24 inches, each \$3.25; 2 to 3 feet, each \$4.50.

Elegantissima. Yellow Column Arborvitae (S). Of narrow, pyramidal outline. Foliage effect golden in summer, bronze in winter. Valuable for color contrast in mixed evergreen plantings. 18 to 24 inches, each $\$ 2.50 ; 2$ to 3 feet, each $\$ 3.50$.

Ellwangeriana. A low, broad pyramid with slender branches; foliage intermediate in texture between Ericoides and American. 18 to 24 inches, $\$ 2.25 ; 2$ to 3 feet, $\$ 3.25$.

Occidentalis Compacta Globosa. (Globe Arborvitae.) A dense, globular form. under 4 feet high, with pretty light green foliage. Of value for the front of groups, for outlining driveway, circles, etc. 12 to 15 inches, $\$ 2.00 ; 15$ to 18 inches, $\$ 2.75$.

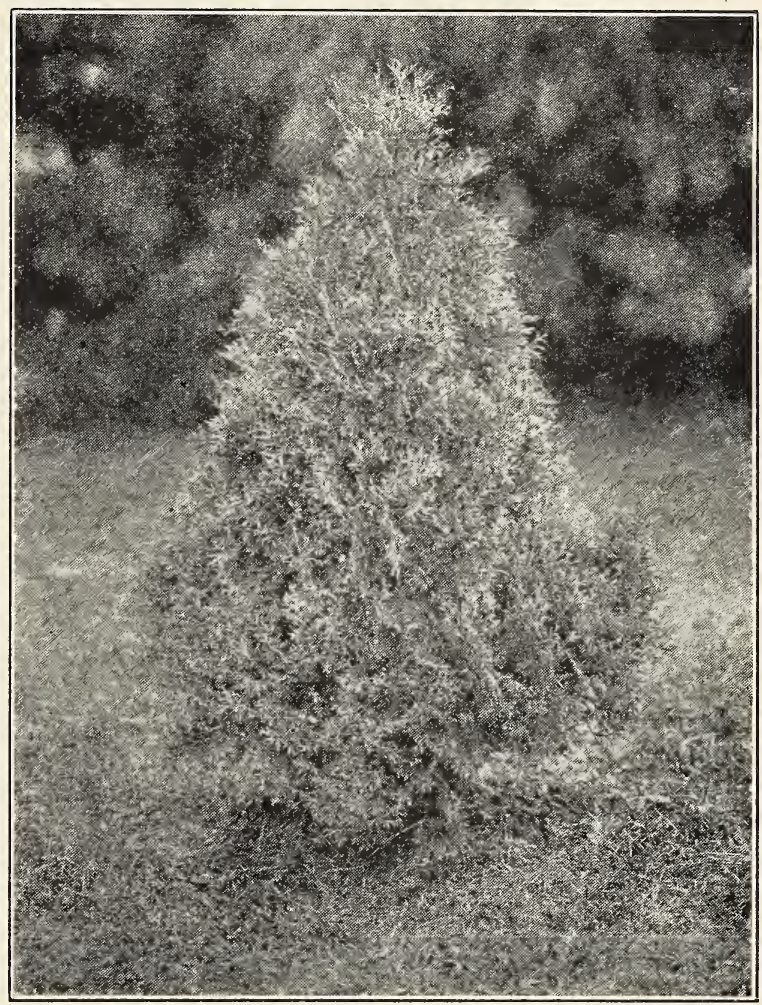

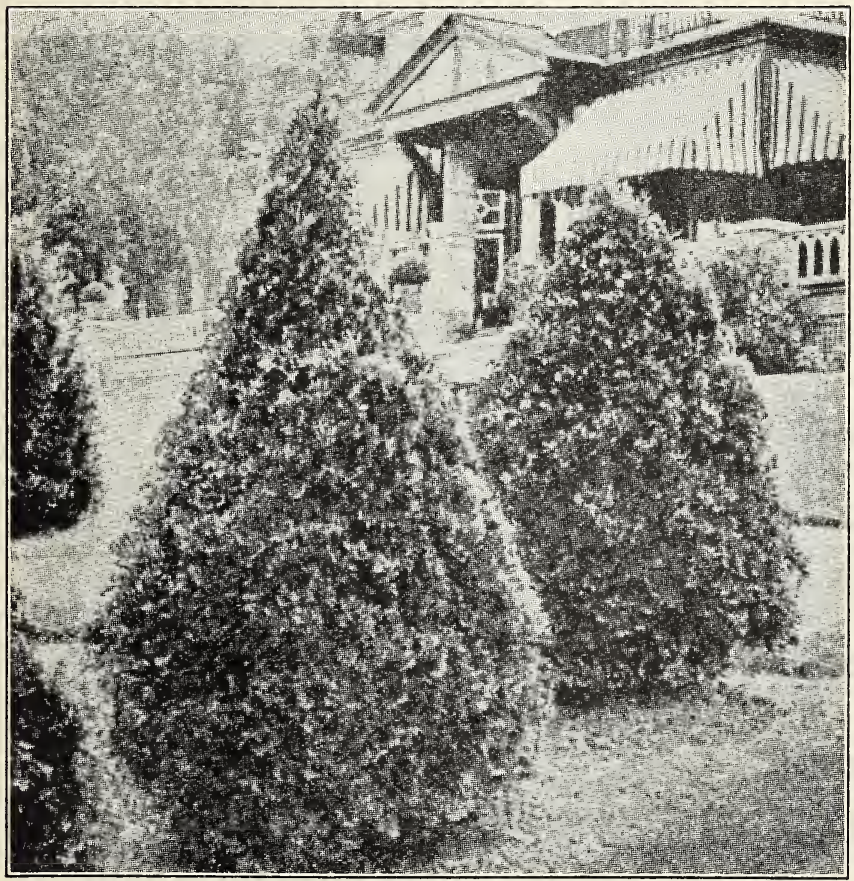

Siberian Arborvitae
Thuya American

\section{OCCIDENTALIS WAREANA}

(Siberian Arborvitae.) Raised by and named for Mr. Thomas Ware, an English nurseryman, who pro. duced it about 1850. It matures at 6 to 8 feet. It is conical in outline and covered with dark green foliage which is somewhat different from the American Arborvitae, being much heavier and deeply crested. The branches are short and stiff. It is much used for foundation planting for hedges. The name Siberian has been given to it because of its rugged constitution. A symmetrical, compact grower, very long lived. $18-24$ in. each $\$ 2.50 ; 10$ for $\$ 22.50$; $2-3$ ft. ea. $\$ 3.50 ; 10$ for $\$ 32.50$. 
Occidentalis aurea Hoveyi. (Hovey's Golden Arborvitae.) A distinct, compact, hardy American seedling; dense and conical, with light golden green foliage. 18 to 24 in. ea. $\$ 2.50 ; 2$ to $3 \mathrm{ft}$. ea. $\$ 3.50$.

Occidentalis lutea. (George Peabody Golden). A handsome tree of pyramidal form, with foliage of clear, lasting yellow. The most brilliant golden variety. 18 to $24 \mathrm{in}$. ea. $\$ 3.50 ; 2$ to $3 \mathrm{ft}$. ea. $\$ 4.50$.

Occidentalis pyramidalis. (Pyramidal Arborvitae). Forms a tall, slender column of dark green, similar to the Irish Yews. It keeps its fine color well all season. Quite hardy. 18 to 24 in. ea. $\$ 2.50$; 10 for $\$ 22.50 ; 2$ to 3 ft. ea. $\$ 3.00 ; 10$ for $\$ 27.50$; 3 to $4 \mathrm{ft}$. ea. $\$ 4.50 ; 10$ for $\$ 42.50 ; 4$ to $5 \mathrm{ft}$. ea. $\$ 7.00$.

Occidentalis (Tom Thumb). Similar to T. Occidentalis ericoides, but greener, smaller and more compact. Good for low borders. 15 to 18 in. ea. $\$ 1.75 ; 10$ for $\$ 15.00 ; 18$ to 24 in. ea. $\$ 2.25 ; 10$ for $\$ 20.00$.

Occidentalis Rosenthali (Rosenthale Arborvitae). A slow-growing, compact, pyramidal type with rich, dark green foliage. Quite rare and very ornamental. 18 to 24 in. ea. $\$ 3.00 ; 2$ to $3 \mathrm{ft}$. ea. $\$ 4.00$.

\section{TSUGA-THE HEMLOCK}

Tsuga Canadensis. As a lawn specimen in full suniight, the lower branches sweep the ground. Tolerant of partial shade also, and its end u rance of shearing adapts it for foundation and bed planting land for use in hed ges. By shearing it bec $0 \mathrm{mes}$ very dense and compact. 18 to 24 inches, \$2.75; 10 for $\$ 25.00$; 2 to 3 feet, $\$ 3.75 ; 10$ for $\$ 35.00 ; 3$ to 4 feet, $\$ 4.75 ; 10$ for $\$ 45.00$.

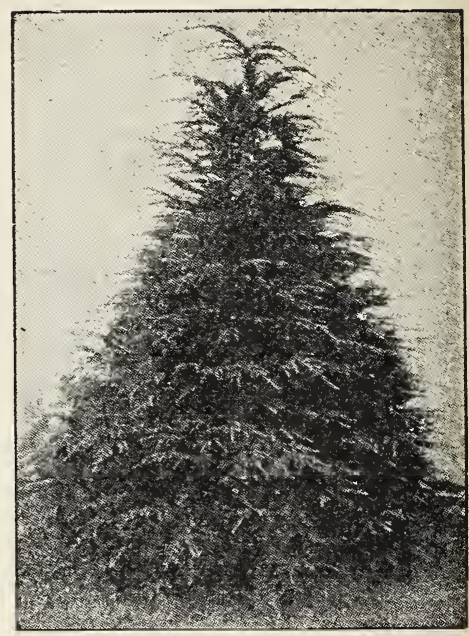

Tsuga Hemlock

\section{THE FOLLOWING EVERGREENS AND BROAD LEAVED EVERGREENS SUITABLE FOR ROCK GARDENS}

Azalea Mollis (Page 9).

Cotoneaster Horizontalis (Page 9).

Daphne Cneorum (Page 9).

Euonymus Radicans (Page 9).

Juniperus Chinensis Sargenti (Page 3).

Juniperus Communis Suecica (Page 3).

Juniperus Chinensis Procumbens (Page 3).

Juniperus Chinensis Globosa (Page 3).

Juniperus Sabina Tamariscifolia (Page 3).

Juniperus Horizontalis (Page 3 ).
Pinus Montana Mughus (Page 5).

Retinospora Filifera Aurea (Page 5).

Retinospora Obt. Nana Compacta (Page 5).

Taxus Baccata Repandens (Page 6).

Taxus Canadensis (Page 6).

Taxus Cuspidata Brevifolia (Page 6).

Thuya Occ. Compacta (Page 7).

Thuya Occ. Globosa (Page 7).

Thuya Orientalis Nana Aurea (Page 6).

\section{GROUND COVER FOR SHADY PLACES}

Euonymus Radicans (Page 9).

Hedera Helix (Page 20).

Pachysandra Terminalis (Page 10).
Taxus Canadensis (Page 6).

Vinca Minor (Page 30).

\section{FOR SUNNY PLACES}

Juniperus Communis Depressa (Page 2).

Juniperus Horizontalis (Page 3).

Juniperus Tamariscifolia (Page 3).

Juniperus Sargenti (Page 3).

Pachysandra Terminalis (Page 10).

\section{PERENNIAL PLANTS SUITABLE FOR ROCK GARDEN PLANTING}

Alyssum Saxatile Compactum (Page 28).

Aquilegia Alpina (Page 28).

Papaver Nudicaule (Page 30).

Asters, Hardy Varieties (Page 28).

Campanula (Page 28).

Hardy Pinks (Page 32).

Papaver Orientale (Page 30).

Platycodon (Balloon Flower) (Page 32).

Primula (Page 32).

Veronica (Page 32).

Myosotis Palustris (Page 30 ). 


\section{BROADLEAF EVERGREEN SHRUBS}

THE varieties included in this chapter are most cumsunly known as the BROADLEAVED EVER. 1 GREENS, hecause of their broad leaves, as compared to the needle-like foliage of the Conifers and other Evergreens.

\section{Azalea}

Calendulacea. One of the most attractive of the flowering shrubs and the most showy of the Azeleas. A very profuse bloomer; the flowers being a light orange or bright red appearing before the leaves and remaining several weeks. 2 to $3 \mathrm{ft}$. ea. $\$ 3.50 ; 10$ for $\$ 32.50$.

Mollis (Bushy well branched). The foliage of this variety is especially attractive. The flowers are a variable orange tan, yellow and red. Plant thrives in both sunny and semi-shaded locations and is very hardy. This shrub associates with the Rhododendron and is very good for foundation planting. 12 to 15 in. ea. $\$ 2.50 ; 10$ for $\$ 22.50$; 15 to 18 in. ea. $\$ 3.50 ; 10$ for $\$ 32.50$.

\section{Buxus-Boxwood}

Boxwood Edging. (B. sempervirens). A very popular and useful plant for edging walks and drives, for bordering garden paths and outlining beds in Perennial and Rose Gardens. Also adapted for window-box use, and for bed planting with mixed evergreens. 8 to 12 in. ea. $60 \mathrm{c} ; 10$ for $\$ 5.00$; $\$ 40.00$ per 100 .

\section{Cotoneasters}

Cotoneaster-Horizontalis. (Prostrate Cotoneaster) (VD). Low, spreading plants with small shiny leaves and bright berries that remain on the branches well into the winter. Very choice for rock gardens and the foreground of Evergreen beds. 8 to 12 in. ea. $\$ 1.00 ; 10$ for $\$ 9.00$.

Daphne Cneorum (Garland Flower, Rose Daphne). A low, spreading Evergreen plant that is excellent for the foreground of Evergreen beds and for rockeries. Small, tubular pink flowers of intense fragrance are borne in clusters and adorn the plant in May and intermittently all Summer. A choice, comparatively uncommon plant of rare merit. Daphne does best in a light, well drained soil, in a sunny, protected location. 12 to 15 in., ea. $\$ 1.50 ; 10$ for $\$ 12.50$.

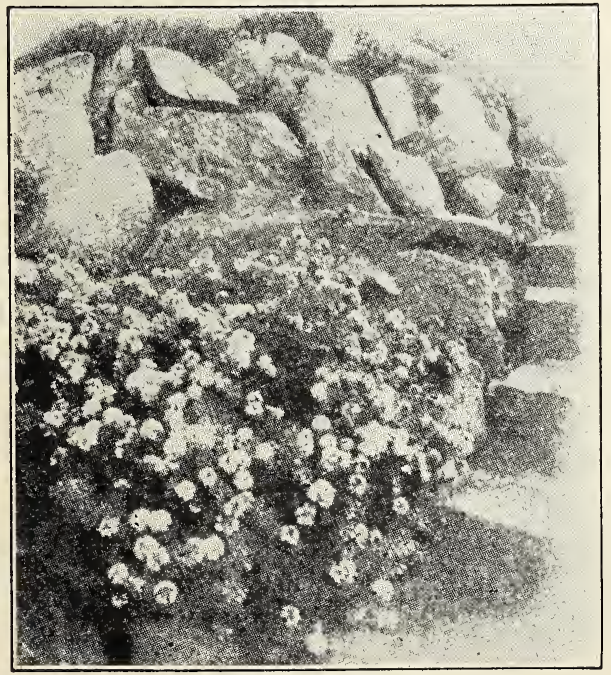

Daphne Cneorum

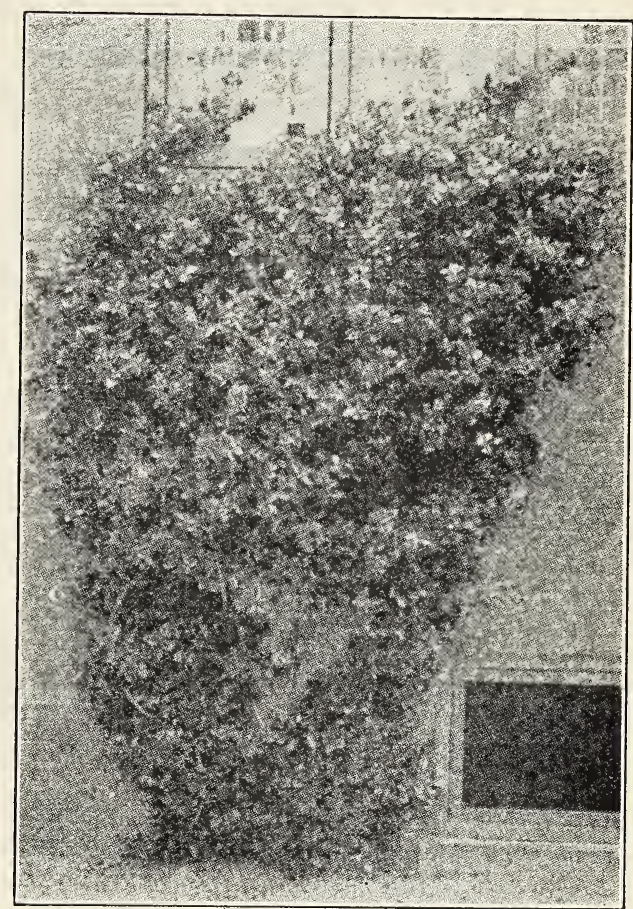

Euonymus Radicans

Euonymus Radicans (Wintercreeper). Attractive dark greenleaved Evergreen plants of slow-growing habit and very hardy. For covering walls, house foundations, as an undergrowth in Evergreen borders or for attractive edging. 8 to 12 in. ea. 40c; 10 for $\$ 3.50 ; 12$ to 15 in. ea. 50c; 10 for $\$ 4.50$.

Euonymus Radicans Carrierei. Glossy Wintercreeper. Large, handsome, glossy, evergreen leaf; climber for buildings and walls. 8 to 12 in. ea. $45 \mathrm{c} ; 10$ for $\$ 4.00 ; 12$ to 15 in. ea. $55 \mathrm{c} ; 10$ for $\$ 5.00$.

Euonymus Radicans Variegata (Varigated Wintercreeper. Similar to last, leaves varigated with creamy white. 8 to 12 in. ea. $45 \mathrm{c} ; 10$ for $\$ 4.00$; 12 to 15 in. ea. $55 \mathrm{c} ; 10$ for $\$ 5.00$.

Euonymus Vegetus. (Bigleaf Wintercreeper). Scarlet fruited, strong growing evergreen vine. Handsome foliage, use as ground cover. 8 to 12 in. $45 \mathrm{c}$; 10 for $\$ 4.00 ; 12$ to 15 in. ea. $55 \mathrm{c} ; 10$ for $\$ 5.00$.

\section{Ilex-The Hollies}

Ilex Glabra (Inkberry). A native Evergreen shrub, low and bushy and well suited for use in the foreground of Broadleaved Evergreen plantings and for naturalistic effects. Glossy black berries. 15 to 18 in., \$2.00.

Ilex Opaca (American Holly). Our native Holly so familiar in Christmas decorations. When several trees are planted near together they usually bear a profusion of red berries that add to their interest. For use south of New York except in protected places along the coast. 15 to 18 in., $\$ 2.00 ; 10$ for $\$ 17.50 ; 18$ to 24 in., $\$ 2.75$; 10 for $\$ 25.00$. 


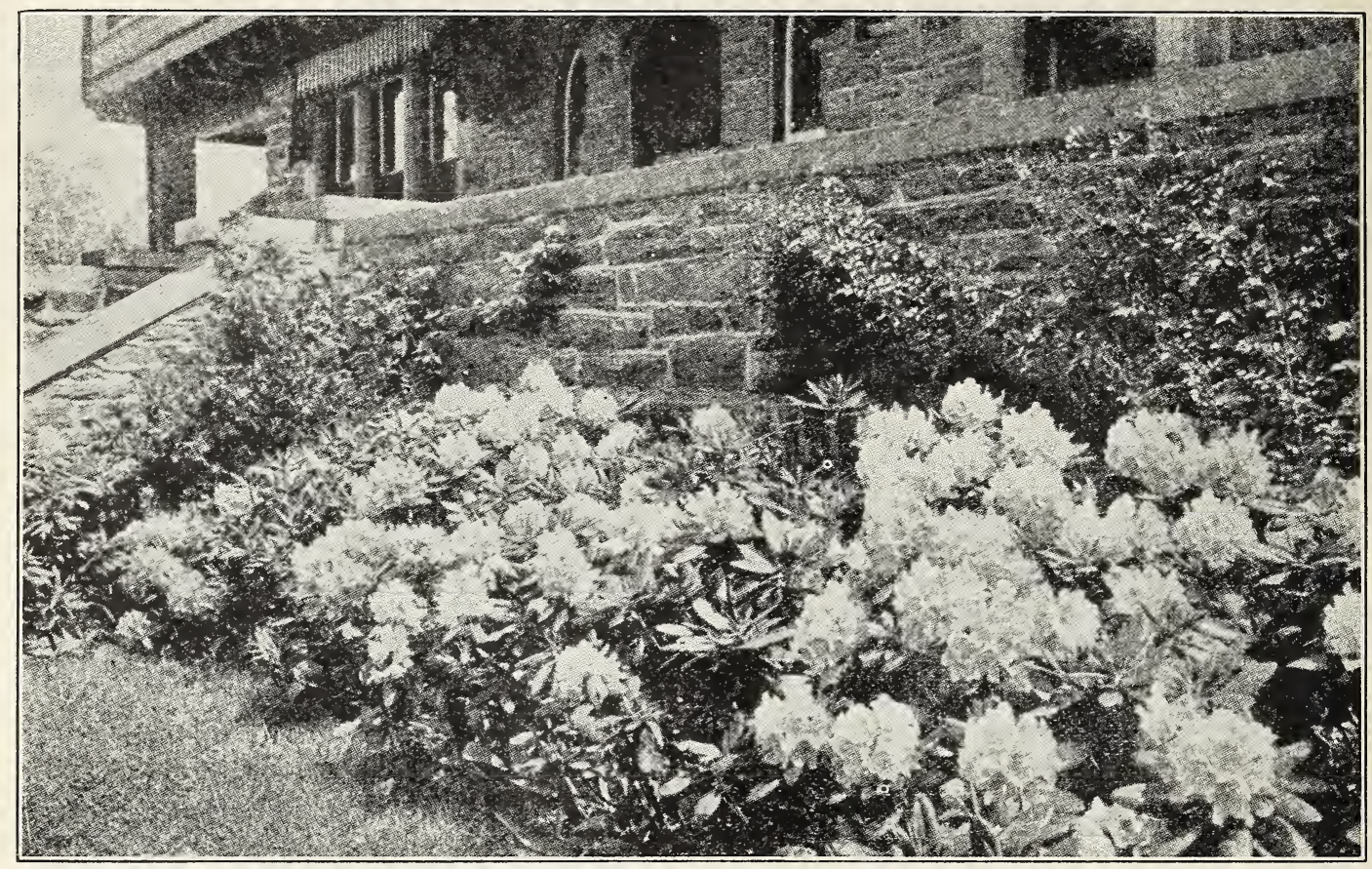

Foundation Planting of Khododendrons

\section{KALMIA}

Latifolia (Mountain Laurel; Calico Bush). Next to the rhododendron this is our most beautiful hardy evergreen. Its quaintly formed, rosy white buds and flowers cluster in great trusses and contrast finely with the shining, dark leaves. 15 to 18 in., $\$ 2.50$; 10 for $\$ 22.50 ; 18$ to 24 in., $\$ 3.50 ; 10$ for $\$ 32.50$.

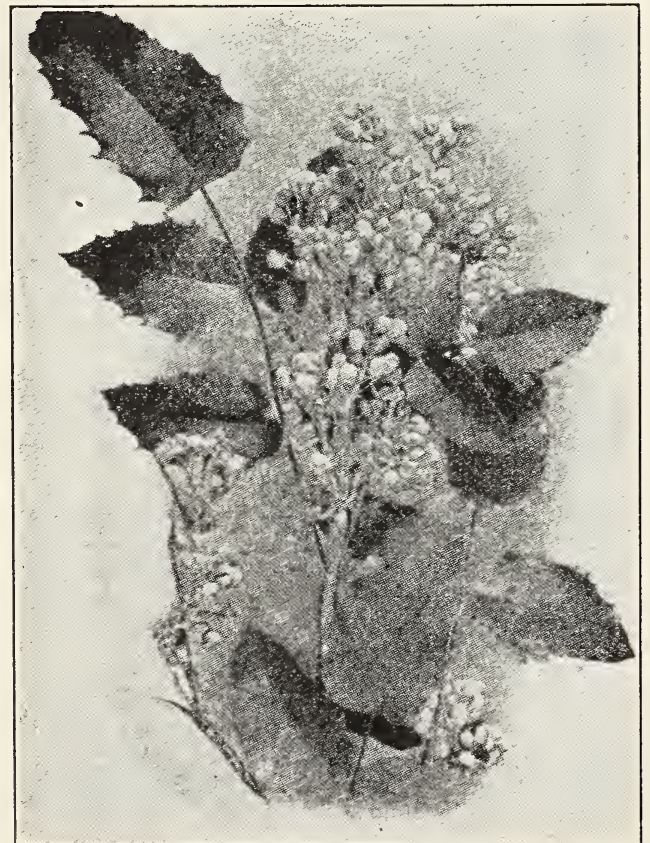

Holly-leaved Mahonia

\section{MAHONIA}

Aquifolium. (Holly-leaved Mahonia.) Sometimes included under berberis. Handsome native evergreen of medium size, with shining, prickly leaves and showy, bright yellow flowers in May, followed by bluish berries. Quite useful in decorative planting for its neat habit and fine 'bronze-green leaves. 15 to 18 inches each $\$ 1.50 ; 10$ for $\$ 12.50 ; 18$ to 24 inches each $\$ 2.25$; 10 for $\$ 20.00$.

\section{RHODODENDRONS}

Rhododendrons are considered to be one of the most popular plants for all-year round effects. Their masses of foliage retain their coloring throughout the entire year, and provide a pleasing touch of green in the winter landscape. As they favor partially shaded situations they are invaluable for shady nooks about the house or lawn.

Catawbiense. Very hardy with attractive foliage of round shining green leaves. The flowers are borne very abundantly in trusses and come in shades of lavender and purple, appearing early in June. 18 to 24 inches each $\$ 3.00 ; 10$ for $\$ 27.50 ; 2$ to 3 feet each $\$ 4.00 ; 10$ for $\$ 37.50$.

Maximum. Foliage very large and smooth; flowers are white with rosy blush and also white. This shrub grows naturally in certain mountainous regions of Pennsylvania, Virginia and North Carolina. Very attractive for natural effects along walks and drives. 2 to 3 feet. Each $\$ 4.00 ; 10$ for $\$ 37.50 ; 3$ to 4 feet, each $\$ 5.00 ; 10$ for $\$ 45.00$.

\section{Pachysandra}

Pachysandra Terminalis (Japanese Spurge). An evergreen ground cover valuable for massing in shady places where grass will not grow and as undergrowth in evergreen beds. When once established it becomes a veritable mat, completely covering the ground. Each 20c; 10 for $\$ 1.50$; $\$ 12.50$ per 100. 


\section{Ornamental Trees}

RNAMENTAL TREES occupy a very important place in landscape decorations. They are often thought of chiefly for shade, yet there are varieties that vie with the choicest flowering plants in the wealth and beauty of their bloom and showy fruit. The foliage of some kinds turn into such gorgeous Autumn tints that they end the season in a blaze of glory. Background, accent and wind. break-effects are readily achievable through the use of ornamental trees. Varieties that hold their dried leaves all Winter, harbor the Winter birds; those with contrasting shades of bark add interest to the landscape all year round.

\section{ACER-MAPLE}

Dasycarpum. (Silver Maple). L. A reliable, easily transplanted, rapid grower, that does well in wet as well as drier soils. The wood is very brittle and as the tree matures is sub. ject to breakage in wind or ice storms so should not be planted close to buildings. Deeply cut leaves, silvery beneath. 8 to 10 feet. Each $\$ 1.50 ; 10$ for $\$ 13.50$.

Dasycarpum Wieri laciniatum. (Wier's Cutleaved silver Maple.) A very beautiful specimen tree, with delicately cut leaves and distinct, half-drooping habit. The leader grows rapidly upright and the slender lateral branches curve gracefully downward. 8 to 10 feet. Each $\$ 2.00 ; 10$ for $\$ 17.50$.

Negundo. (Ash-leaved Maple; Box Elder.) This species is easily distinguished by its pinnate leaves and greenish yellow bark. It grows rapidly into a large, spreading tree, and is valuable for planting timber claims, shelter-belts, etc., in the West, where it endures both drought and cold. 6 to 8 feet. Each $\$ 1.00 ; 10$ for $\$ 9.00$.

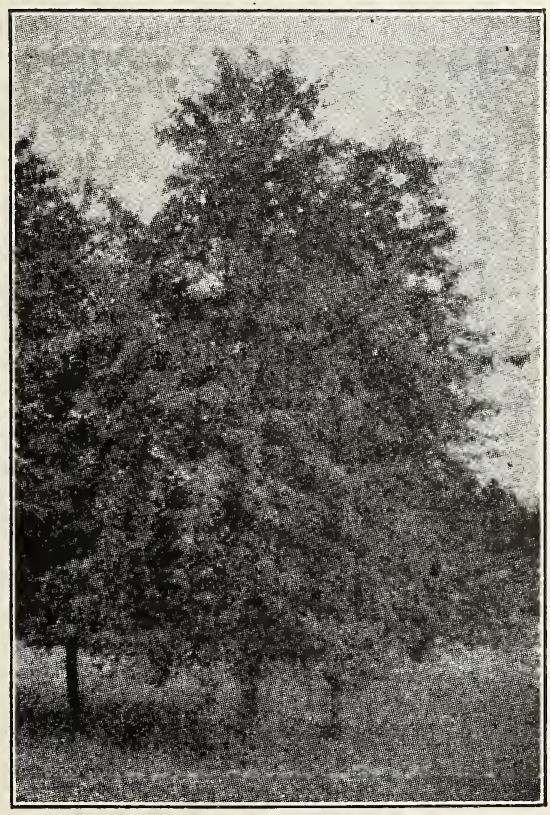

Silver Maple

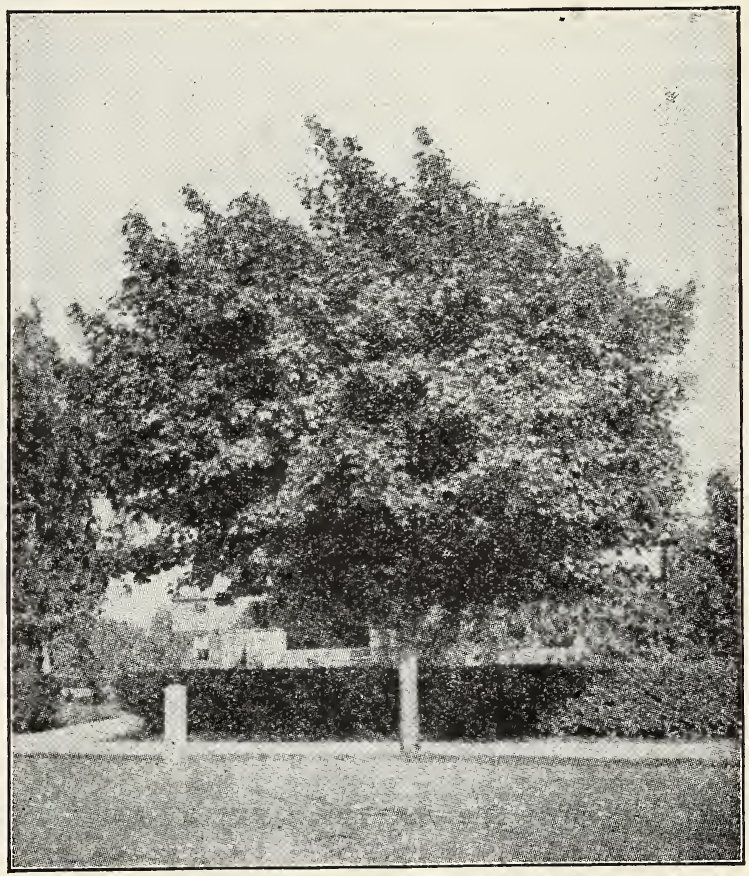

Norway Maple

Platanoides. (Norway Maple.) M. A rapid grow. ing, broad-headed symmetrical tree with large, deep green leaves, that turn yellow in the Fall. For either lawn or street planting. The larger sizes offered below are suitable for immediate results. 8 to 10 feet. Each $\$ 4.00 ; 10$ for $\$ 35.00$.

Schwedleri. (Schwedler Maple.) M. The new leaves are red or purplish, later turning to dark ricn green. In open groupings with other trees it lends a note of color contrast. Valued also for specimen and avenue planting. 6 to 8 feet. Each $\$ 4.50 ; 10$ for $\$ 42.50$.

Saccharum. (Sugar or Rock Maple.) L. A splendid shade tree for lawn, street or avenue planting. Comparatively high headed, of upright oval form when young, becoming broad and spreading with age. 8 to 10 feet. Each $\$ 3.00 ; 10$ for $\$ 27.50$.

Atropurpureum. (Redleaf Japanese Maplo.) Red foliage particularly rich in Spring and Fall. For speeimen planting or in combination with Evergreens, supply limited. 15 to 18 in., each $\$ 4.50 ; 10$ for $\$ 40.00$; $2-3 \mathrm{ft}$., each $\$ 12.50$. 


\section{Aesculus-Horse-Chestnut}

Hippocastanum. (European White-flowering Horse-Chestnut.) A large tree of regular outline, spangled in May with great, upright spikes of white flowers. Has no superior as a specimen flowering tree. 5 to 6 feet. Each $\$ 2.00 ; 10$ for $\$ 17.50$.

Hippocastanum alba fi-pl. (Double-flowering Horse-Chestnut). A superb variety, with large panicles of double flowers, like hyacinth trusses in effect. Has no nuts to litter the lawn. The double blooms are more durable than single ones. 5 to 6 feet. Each $\$ 3.00$.

\section{Ailanthus}

\section{Chinese Sumach; Tree of Heaven}

Gladulosa. An extremely quick-growing tropical-looking tree, with pinnate, palm-like leaves. Valuable becanse it thrives in smoky cities and in soils where other trees perish. Only fertile trees should be planted, as the pollen from infertile sorts is disagreeable. 6 to 8 feet. Each $\$ 1.25 ; 10$ for $\$ 10.00$.

\section{Aralia-Angelica Tree}

Spinosa. (Hercules Club.) A showy native tree, with broad, handsomely cut leaves and huge clusters of small white flowers in July. Its winter effect is unique and handsome. 6 to 8 feet. Each $\$ 1.00 ; 10$ for $\$ 8.50$.

\section{Betula-Birch}

Alba. (European White Birch.) This is the famous Birch of literature. Quite erect when young, its branches begin to droop gracefully with age. Its bark is snow-white, making it very effective in landscape views, especially if grown in front of a background of dark evergreens. 6 to 8 feet. Each $\$ 1.75 ; 10$ for $\$ 15.00$.

Alba pendula laciniata. (Cut-leaved Weeping White Birch.) Many attractive characteristics combine to make this a tree of wonderful grace and beauty. Tall and slender, vigorous, with slender branches in drooping festoons of delicately cut leaves. It colors brilliantly in fall, and its bare white trunk and branches make a beautiful winter picture. 6 to 8 feet. Each $\$ 3.25 ; 10$ for $\$ 30.00$.

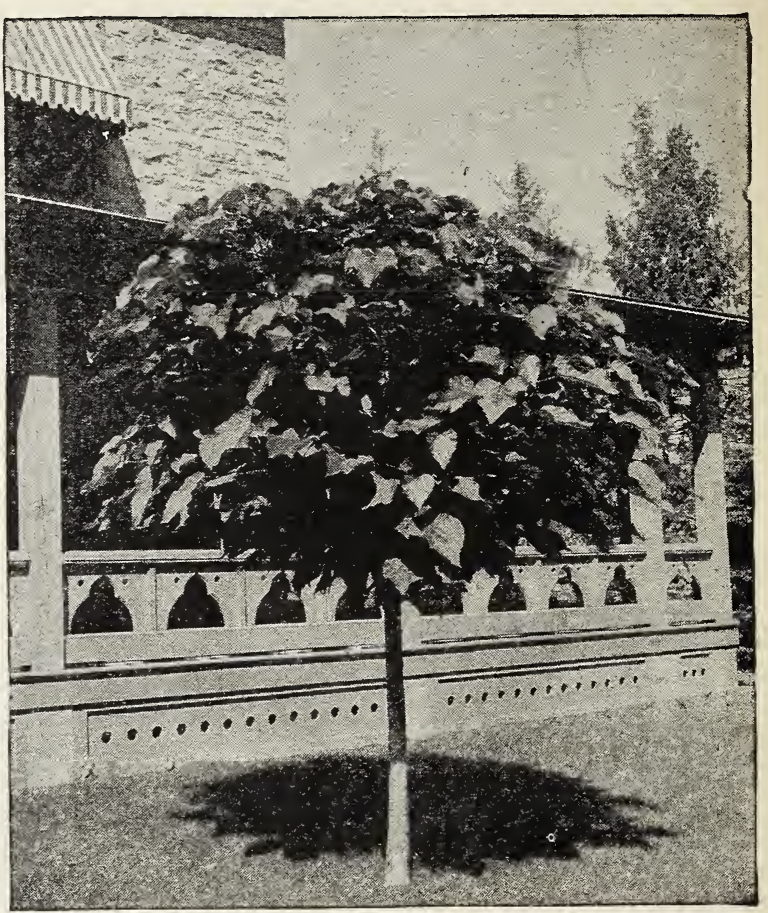

Catalpa Bungei

\section{CATALPA}

Catalpa Bungei. (Umbrella Catalpa.) This tree is grafted on stems 6 to 8 feet, and makes an umbrella shaped top without pruning. It is hardy and flourishes in almost all soils and climates. One of the most antique trees desirable for lawn, park or cemetery planting. The leaves are large, heartshaped, glossy, deep green. 6 to 8 feet. Each $\$ 1.75 ; 10$ for $\$ 15.00$.

Speciosa. Valuable for timber, fence posts, railroad ties, etc., on account of rapid growth and durability. Large heart-shaped, downy leaves, and compound panicles of white flowers, tinged with violet and dotted with purple and yellow. 8 to 10 feet. Each $\$ 1.00 ; 10$ for $\$ 8.00$.

\section{Cerasus-Cherry Flowering Cherries}

Japan Weeping. A weeping form worked on 4 to 6 feet stems, the pendulous limbs drooping to the ground. A beautiful object when covered with its rosy masses of bloom in early spring. Each $\$ 3.50$.

Double White Flowering Cherry. A charming small tree with branches completely covered with a mass of large double white flowers in May. 3 to 4 feet. Each $\$ 3.50$.

\section{Cercidiphyllum-Kadsura Tree}

Japonicum. A beautiful, bushy tree, with slender branches and light green foliage. When young it is somewhat pyramidal in habit, and at all times it is distinctly graceful. 5 to 6 feet. Each $\$ 3.50$. 


\section{Cornus-Dogwood}

Florida (White-flowering Dogwood.) The great white flowers are three inches and more in width, lasting for as many weeks. Besides this fine characteristic, the bright red bark on its young growths makes it attractive and cheery in winter. Tree is branching in habit and blooms when quite small. 3 to 4 feet, each $\$ 1.00 ; 10$ for $\$ 9.00 ; 4$ to 5 feet, $\$ 1.75,10$ for $\$ 16.00 ; 5$ to 6 feet, $\$ 3.00,10$ for $\$ 27.50$.

Florida rubra. A new and rare variety, with handsome red flowers displayed at even an earlier age than those of the White Dogwood. 2 to 3 feet, each $\$ 2.25 ; 3$ to 4 feet, each $\$ 3.25 ; 4$ to 5 feet, each $\$ 5.00$.

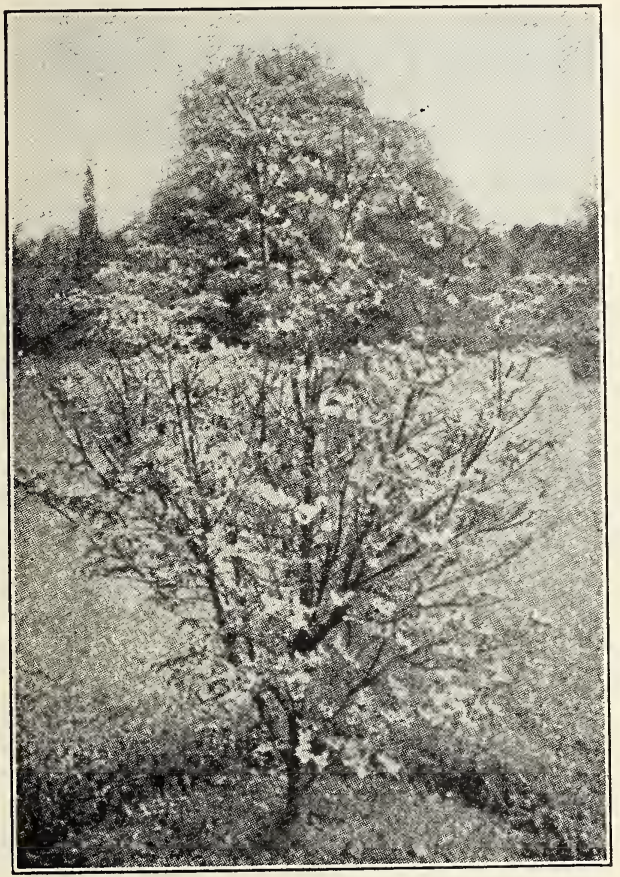

Cornus Florida

\section{Crataegus-Flowering Thorn}

Oxyacantha. (Double White Hawthorn.) When in bloom, a mass of clustered double, rose-like white blossoms in May. This is the famous May Thorn of English gardens. Has spreading branches and stout spines. The blooming period is followed by a display of scarlet fruits, which remains a long time. Makes a pleasing flowering hedge. 4 to 5 feet. Each $\$ 1.75 ; 10$ for $\$ 15.00$.

\section{Oxyacantha Paulii. (Paul's Double Scarlet} Thorn.) Of quick growth, showy, and perhaps the best sort. The large, perfectly double flowers in May are rich, glowing crimson. 4 to 5 feet. Each $\$ 1.75 ; 10$ for $\$ 15.00$.

\section{Fagus-Beech}

Sylvatica Riversii. (Rivers' Blood-leaved Beech.) Where a large tree with purple foliage is wanted, nothing equals this. It is generally conceded to be the finest of all purple-leaved trees. Though it varies in intensity of color from early spring until late fall, the leaves are always a rich shade. 2 to 3 feet, each $\$ 5.00 ; 3$ to 4 feet, each $\$ 6.00$.

\section{Ginkgo-Maidenhair Tree}

Biloba (Salisburia adiantifolia.) A distinguished Japanese tree, of columnar growth when young, spreading with age into an odd, sketchly outline. Its thick, leathery leaves are clean-cut and shaped like the leaves of the Maidenhair Fern. A rare and elegant tree that is robust enough to endure general city planting. Its unique appearance and habit of growth make it a valuable acquisition. Grows fast; has no insect or fungous enemies. 6 to 8 feet. Each $\$ 2.00$.

\section{Liriodendron}

Tulipifera. (Tulip Tree.) A tall, magnificent native, of rapid, pyramidal growth. Its smooth, erect gray bole rises to a great height, and is clothed with a splendid vesture of large, odd. shaped, glossy leaves and spangled in spring with large, tulip-shaped flowers of greenish yellow and orange. One of our most distinguished tall trees for broad avenues, parks and lawns. 6 to 8 feet. Each $\$ 2.00 ; 10$ for $\$ 17.50$.

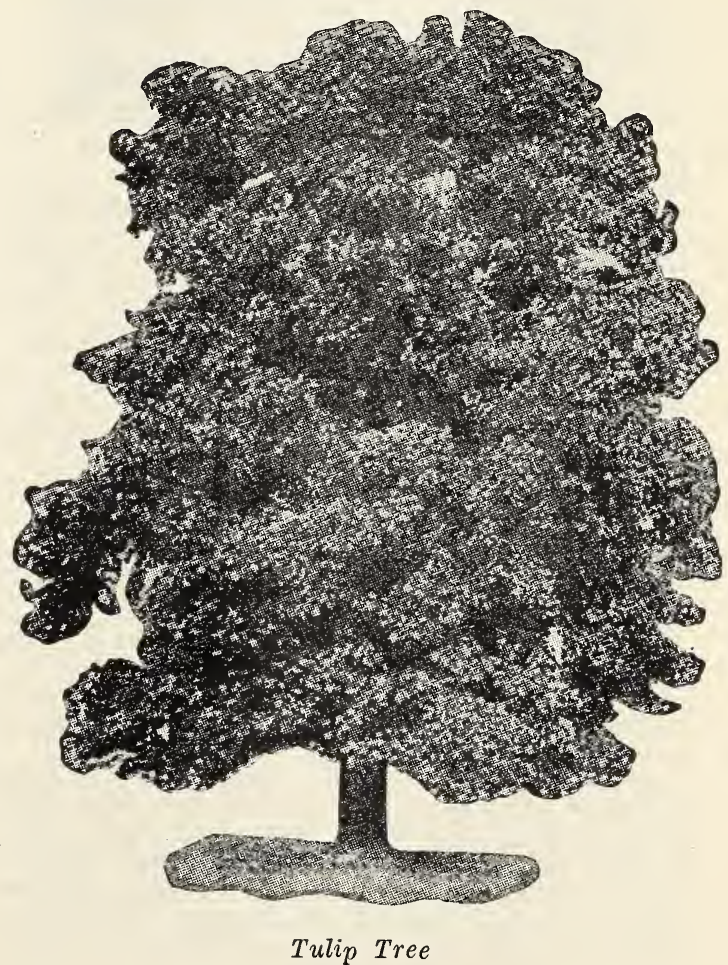




\section{Morus-Mulberry}

Mulberry, (Tea's Weeping). Forms a perfect shaped head, with long, slender, willowy branches, drooping to the ground in light, airy gracefulness. It has beautiful foliage, is hardy, safe and easy to transplant. Admirably adapted for small or large grounds, or for cemetery planting. Each $\$ 3.00$; 10 for $\$ 27.50$.

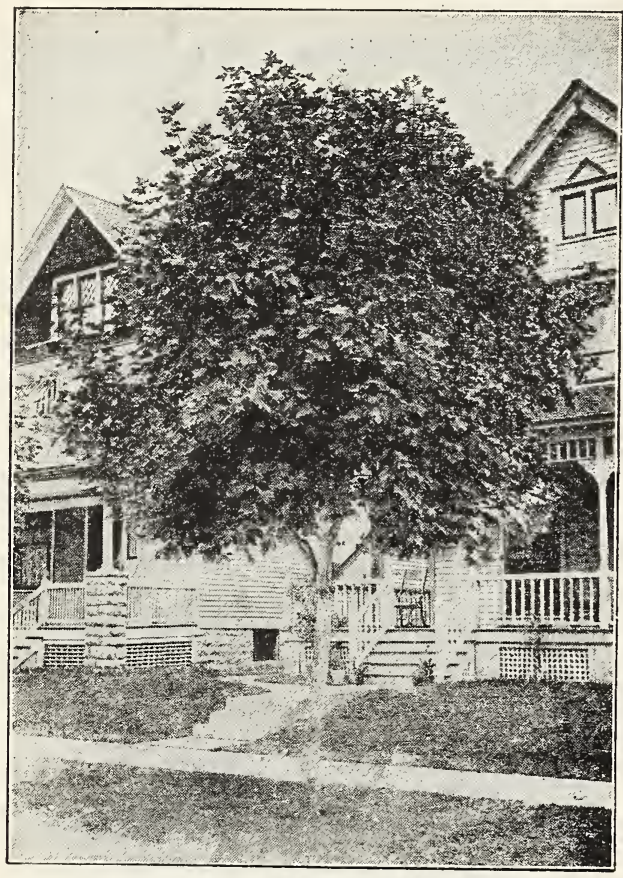

Sycamore

\section{Platanus-Plane Tree; Sycamore}

Orientalis (Oriental Plane.) One of the oldest cultivated trees, and among the best for street and avenue planting. It grows rapidly to grand size, is bold, picturesque, hardy, healthy, free from insects, vigorous in all soils, especially along the water's edge. A lofty, wide-spreading tree, with large, leathery, clear-cut leaves that turn yellow in fall. 8 to 10 feet. Each $\$ 2.00 ; 10$ for $\$ 18.00$.

\section{Populus-Poplar}

Bolleana. Useful in breaking the monotony of lower round-topped trees. Will grow to a tall spire 80 feet high. Its leaves are glossy green, silvery beneath. Each $\$ 2.00 ; 10$ for $\$ 17.50$.

Carolina. A vigorous, native pyramidal tree of rapid growth, with large glossy leaves; valuable for quick shade. Makes a fine spreading head if well cut back the first few seasons. 8 to 10 feet. Each $60 \mathrm{c} ; 10$ for $\$ 5.00$.

Lombardy. The selective appreciation of trained landscape builders is getting this fine type into much more general use. Old trees which were thoughtfully placed, are outstanding landmarks today; their great height, dense slenderness, and sombre silhouette against the skyline, creating an impressive, picturesque old-world effect. 8 to 10 feet. Each $\$ 1.00 ; 10$ for $\$ 7.50$.

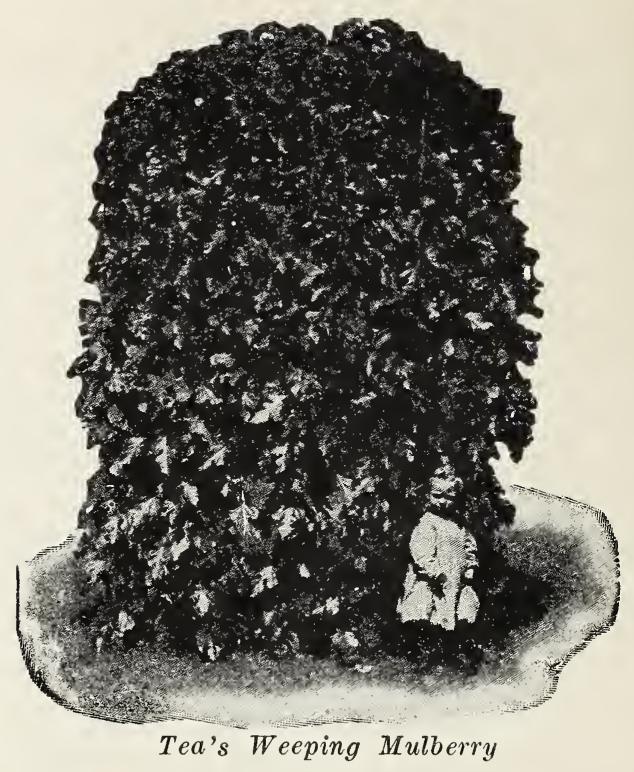

\section{Prunus-Plum}

Pissardii. (Purple-leaved Plum.) A distinct and handsome little tree, covered with a mass of small, white, single flowers in spring, later with showy, pinkish purple leaves that deepen in color to the end of the season. Valuable for ornamental hedges or planting in quantity for contrast. 2 to 3 feet. Each 75 ; 10 for $\$ 6.50$. 3 to 4 feet. Each $\$ 1.00 ; 10$ for $\$ 9.00$.

\section{Pyrus-Flowering Crab}

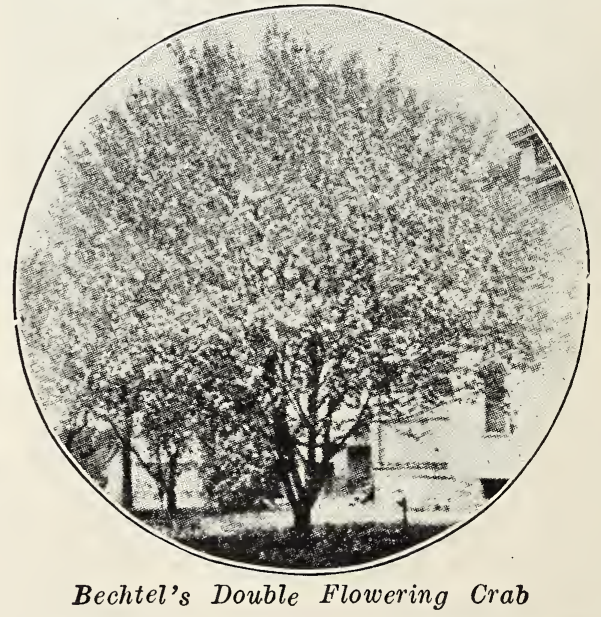

Angustifolia Bechtelii. (Bechtel's Flowering Crab.) A low, bushy tree, the most beautiful of all the fine varieties of Flowering Crabs. At a distance the tree seems to be covered with dainty little roses of a delicate pink color. Blooms when quite young. The flowers are exceedingly fragrant. 3 to 4 feet. Each $\$ 1.25 ; \cdot 10$ for $\$ 10.00$. 4 to 5 feet. Each $\$ 1.50 ; 10$ for $\$ 14.00$. 
Floribunda. (Flowering Crab.) A large shrub or small tree, often thorny, with rose-red flowers borne in great profusion in May. The fruit is red and small, on long stems. 3 to 4 feet. Each $\$ 1.25 ; 10$ for $\$ 10.00$. 4 to 5 feet. Each $\$ 1.50 ; 10$ for $\$ 14.00$.

\section{Quercus-Oak}

Coccinea. (Scarlet Oak.) A grand, roundtopped tree, with bright green, deeply eut leaves that color to sparkling red in fall. 6 to 8 feet. Each $\$ 3.00 ; 10$ for $\$ 27.50$. 8 to 10 feet. Each $\$ 4.00$; 10 for $\$ 37.50$.

Palustris. (Pin Oak.) The tree is shapely and symmetrical, leaves are of a beautiful tone of green, in autumn fading to a brilliant scarlet. This is one of the most desirable trees for street and avenue planting. Ultimate height, 50 to 60 feet. 8 to 10 feet. Each \$3.50. 10 to 12 feet. Each $\$ 4.50$.

\section{Robina Hispida}

Rose Acacia Tree Form (Grafted). Top-worked by grafting on straight standard stock to make this shrub tree-shaped. Very attractive and desir. able in this form. 4 to 5 feet. Each $\$ 1.50 ; 10$ for $\$ 12.50$.

\section{Salix-Willow}

Babylonica. (Weeping Willow.) A fine, drooping tree with slender branchlets. Excellent for planting on the banks of streams or lakes, but will thrive well in dry locations. Often used for cemetery planting. 8 to 10 feet. Each \$1.25; 10 for $\$ 11.00$.

Babylonica dolorosa. (Wisconsin Weeping Willow.) Of similar fine liabit, but hardy farther north. In other respects like the type. 8 to 10 feet. Each $\$ 1.25 ; 10$ for $\$ 11.00$.

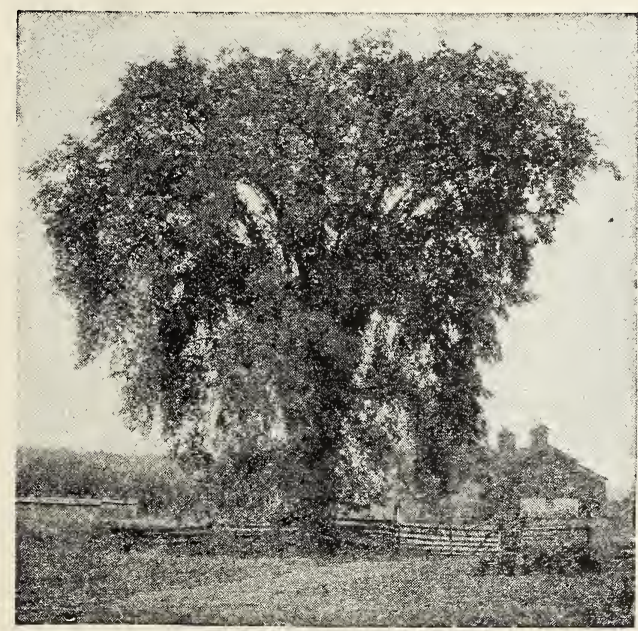

American Elm

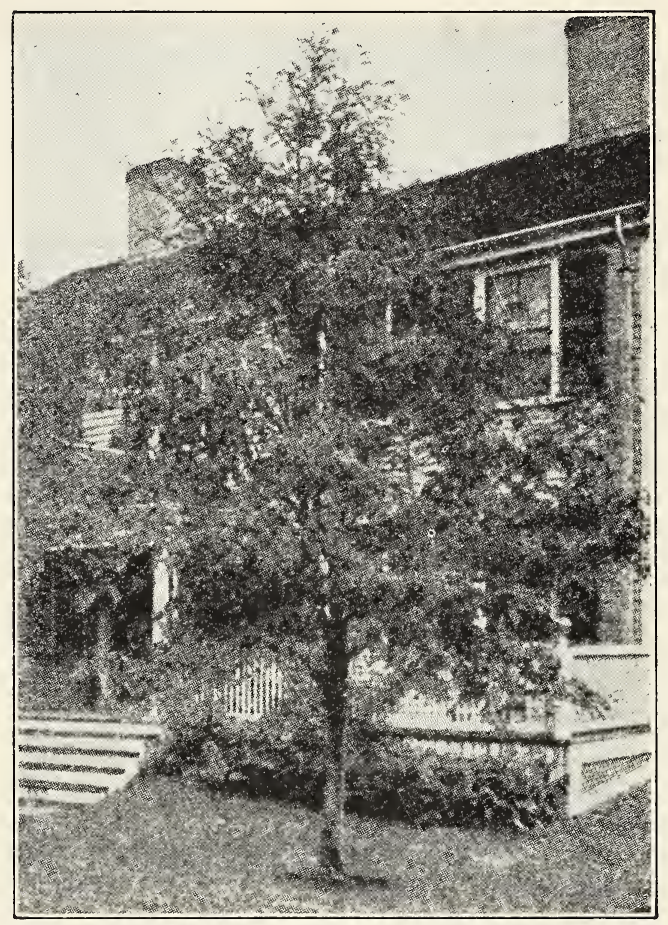

European Mountain Ash

\section{Sorbus-Mountain-Ash}

Aucuparia. (Pyrus Aucuparia.) (European Mountain Ash.) Hardy, erect, with smooth bark and dense, regular head; berry clusters large and bright. A most beautiful, decorative flowering tree for a small lawn. 6 to 8 feet. Each \$1.50; 10 for $\$ 13.50$.

\section{Tilia-Linden, Basswood}

Americana. (American Linden.) A stately tree, with large, shining cordate leaves. Particularly valuable for its beautiful white wood. Its flowers appear in July. 8 to 10 feet. Each \$1.75; 10 for $\$ 15.00$.

Platyphyllos. (Large-leaved European Linden.) An exceedingly broad-leaved variety, flowering in June. The earliest of the Lindens. 6 to 8 feet. Each $\$ 2.00 ; 10$ for $\$ 17.50$.

\section{Ulmus-Elm}

American. A noble native tree of great size and wide spread, with graceful drooping branches and handsome leaves. One of the best tree types for towering, heady effect and wide-spread shade, in the yard itself. Indispensable to shaded parks, and largely used along the sides of wide avenues. 8 to 10 feet. Each $\$ 1.50 ; 10$ for $\$ 14.00$. 10 to 12 feet. Each $\$ 2.25 ; 10$ for $\$ 20.00$. 


\section{Ornamental Shrubs}

PEOPLE generally, are appreciating more the permanent value and beauty of shrubs. The charm 1 and grace they lend to the home grounds is invaluable, and if judicious selection is made, it is possible to have a continuous succession of bloom from early in April to the days when the frost again nips the flowers of the very latest bloom.

\section{ALTHEA OR ROSE OF SHARON}

\section{(Hibiscus Syriacus)}

The Altheas are fine, free-growing flowering shrubs of very easy cultivation. Desirable on account of flowering in August and September, when nearly every other shrub or tree is out of bloom. They are of good size, many colored, at. tractive. Perfectly hardy and can be had in various colors if desired. Entirely free from all insect pests; always give delight and satisfaction. 2 to 3 feet. Each 60c; 10 for $\$ 5.50$.

Almond. (Double Flowering Almond.) The blossoms are double like roses, set closely on the twigs, and appear before the leaves in the early spring. We can supply both white and pink. 2 to 3 feet. Each $75 \mathrm{c} ; 10$ for $\$ 6.50$.

Barberry-Thunbergii. (From Japan.) A very pretty species of dwarf habit, small foliage, changing to a beautiful coppery red in autumn. Valuable as an ornamental hedge. 24 inches. Each $40 \mathrm{c} ; 10$ for $\$ 3.50 ; 100$ for $\$ 25.00$.

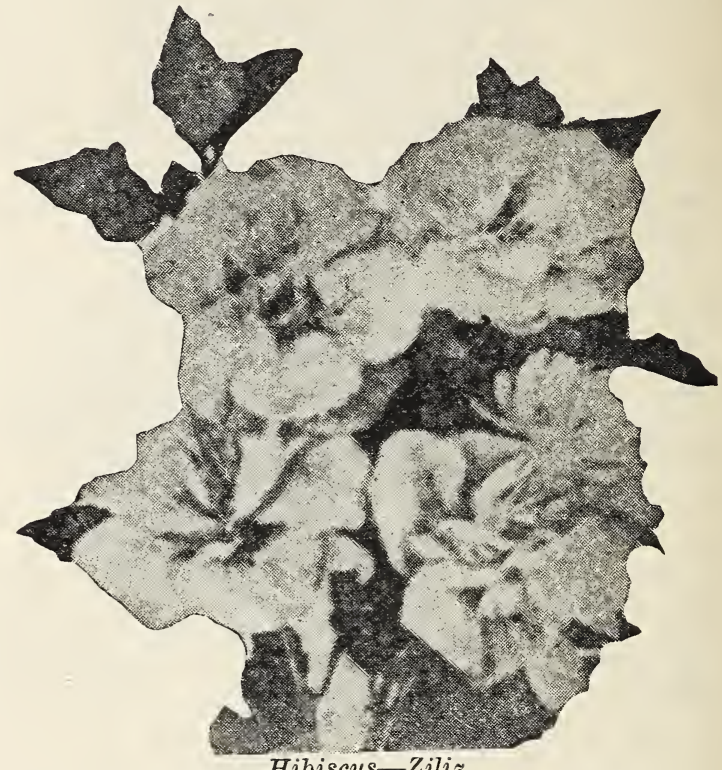

Hibiscus-Ziliz

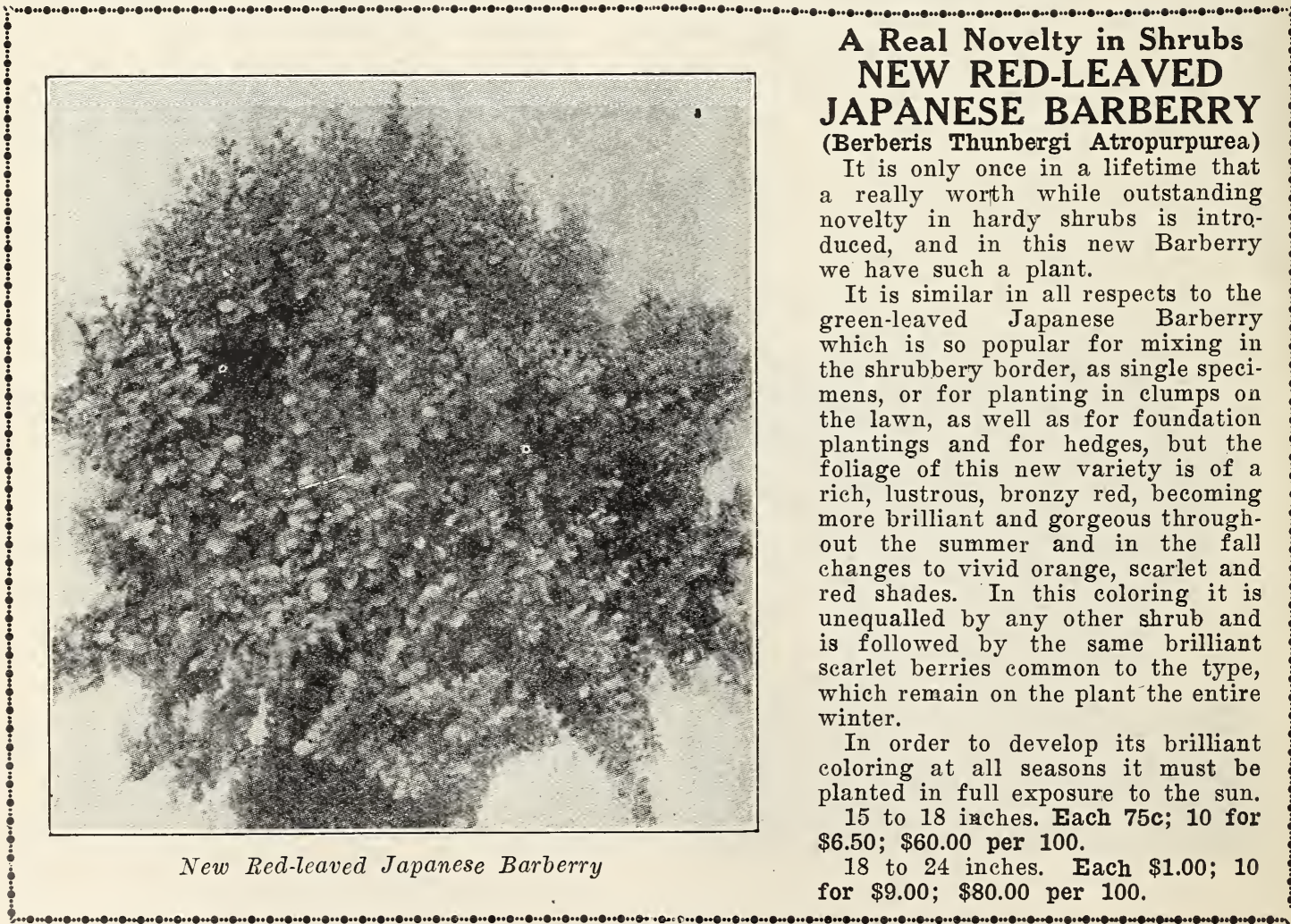


Buddleia Variabilis Magnifica. (Butterfly Shruo or Summer Lilac.) One of the most desirable summer flowering shrubs, beginning to bloom in July, it continues until cut by severe frost. The flowers are of a pleasing shade of violet mauve, and are borne in dense cylindrical spikes from 12 to 15 inches in length by 3 inches in diameter; it succeeds everywhere and flowers freely the first season planted. Each 50c; 10 for $\$ 4.50$.

Callicarpa Purpurea. A pretty shrub from 1 to 4 feet high, more at home south of the Ohio, but practical in the North if given a sheltered position and winter protection. It blooms profusely during August with small auxiliary clusters of pink flowers, these followed by berry-bunches colored a light violet. If top should freeze, young shoots will come up and flower and fruit the next season. 2 to 3 feet. Each 50c; 10 for $\$ 4.50$.

Calycanthus. Fine for lawn and porch decorating. A beautiful sweet-scented shrub; grown as an ornamental plant and is generally known as "Sweet Shrub.' Flowers purplish brown, quite double, exquisitely fragrant; 15 to 18 inches. Each 60c; 10 for $\$ 5.00$.

Clethra Alnifolia. (White Alder, or Sweet Pepper Bush.) One of the best of our native dwarf Shrubs, bearing spikes of pure white, deliciously fragrant flowers during $\mathrm{July}$ and August. 18 to 24 inches. Each 70c; 10 for $\$ 6.00$.

Cornus. (Elegantissima Variegata.) Grows 8 to 10 feet high, with purplish red branches and beautiful silver variegated foliage. This is one of the choicest variegated leaved shrubs, capable of refined compact shape by pruning, of value both summer and winter. 2 to 3 feet. Each $60 \mathrm{c} ; 10$ for $\$ 5.00$.

Lutea. A striking yellow branched form of Stolonifera, very satisfactory for contrasting. 2 to 3 feet. Each 60c; 10 for $\$ 5.00$.

Spaethi Aurea. Leaves broadly margined yellow; of branchy, spreading habit. 2 to 3 feet. Each $60 \mathrm{c} ; 10$ for $\$ 5.00$.

Paniculata. (Gray Dogwood.) Grows 6 to 15 feet, but usually compact; showing a profusion of good sized white flowers in June. Berries white. on noticeable red stems. Bark and underside of leaves gray. 2 to 3 feet. Each 60c; 10 for $\$ 5.00$.

Sibirica. Grows 6 to 10 feet high, with clusters of fine white flowers, succeeded by a fall crop of ornamental berries; stem and branches blood red. 2 to 3 feet. Each 60 c; 10 for $\$ 5.00$.

\section{Cotoneaster}

A class of handsome fruiting shrubs with brilliant autumn foliage and vivid fruits which adapt them to rockery and wall adornment, as well as to any usage in well drained soil with plenty of sunlight. All field grown plants, shipped "balled and burlapped.",

Horizontalis. Densely spreading, horizontal branches. Shiny oval leaves; persisting scarlet fruits. 8 to 12 inches. Each $\$ 1.00 ; 10$ for $\$ 9.00$.
Divaricata. (6 ft.) Oval, lustrous, fall crimsoning leaves. Fruits bright red. 15 to 18 inches. Each $\$ 1.25 ; 10$ for $\$ 11.00$.

Nitens. Related to Divaricata, and similar, with broadly oval lustrous leaves; but differing in the pendulous fruit which is purplish black. 15 to 18 inches. Each \$1.25; 10 for $\$ 11.00$.

Cydonia Japonica. (Japan Quince.) Very early in spring this fine old shrub is completely covered with dazzling scarlet flowers; followed by small, quince-shaped fruits, which are quite fragrant. Growth bushy with protecting thorns. 15 to 18 inches. Each 50c; 10 for $\$ 4.50$.

Desmodium Penduliflorum. (Lespedeza Sieboldi.) A fine half-shrub, the long canes of each season's growth usually winter-killed. The stools become stronger, throwing up more shoots and forming a thick shrub 3 to 5 feet high, in showy late summer bloom. Arched branches, and long, close, drooping racemes of purple-magenta flowers. 2-year plants. Each 60c; 10 for $\$ 5.00$.

Exochorda Grandiflora. (Pearl Bush.) It grows vigorously to a height of 6 to 10 feet. The early buds look like pearls strung on slender threads, May opening them up to long, gleaming sprays of pure white. 2 to 3 feet. Each 75 ; 10 for $\$ 6.00$.

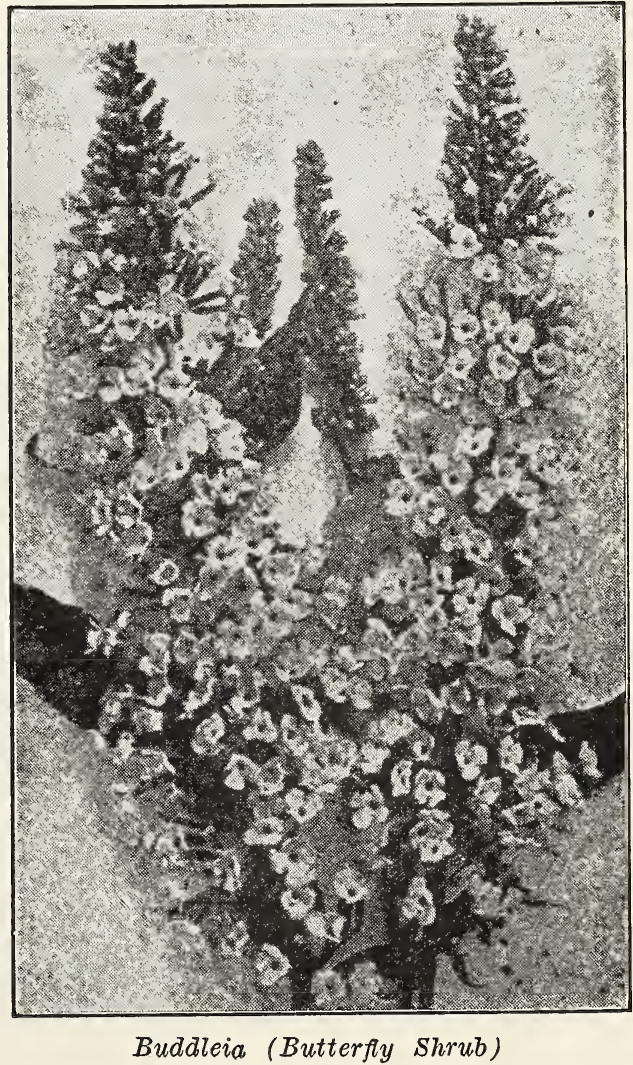




\section{DEUTZIA}

Crenata. Flowers are double white, and tinged with pink; 2 to 3 feet. Each 50c; 10 for $\$ 4.50$.

Pride of Rochester. Grows 6 to 8 feet high; and blooms in May before the others. Flowers large and free, double, white. Each 50c; 10 for $\$ 4.50$.

Lemoinei. Medium large flowers of pure white borne in cone-shaped heads. Each 50c; 10 for $\$ 4.50$.

Gracilis. (Slender Branched.) Dwarf growing, dense, bushy, its drooping branches wreathed with pure white flowers in May. Also valuable for winter blooming in pots. Each 50c; 10 for $\$ 4.50$.

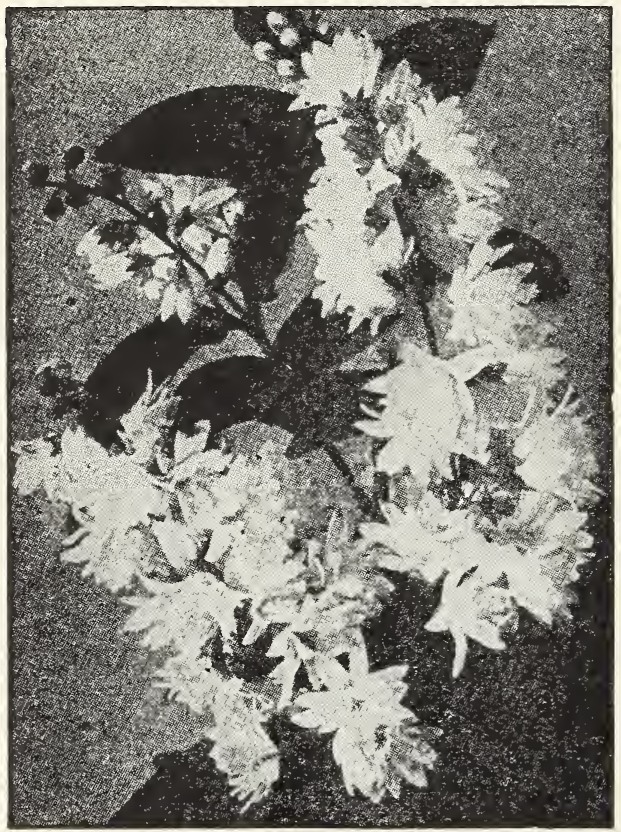

Deutzia

\section{FORSYTHIA (GOLDEN BELL)}

Suspensa. Slender, limply drooping branches strung with bright rosettes of yellow bloom and shiny leaves. These are airily graceful, swaying loose from trellis top or garden wall; or mingle pleasingly with the trailing growth of Honeysuckle, Wichuriana roses and other ground covering vines. 2 to 3 feet. Each 50 c; 10 for $\$ 4.00$.

Forsythia Fortunei. Strong erect habit; bright golden-yellow flowers in early spring. Each 50c; 10 for $\$ 4.00$.

Viridissima. (Golden Bell.) Strong erect habit; bright yellow bell-like flowers in early spring. Each 50c; 10 for $\$ 4.00$.

Purple Fringe. (Rhus Cotinus.) A conspicuous spreading shrub or small tree with large leaves; overhung in mid-summer by cloud-like masses of light, mist-like flowers-having the appearance of smoke at a distance. 2 to 3 feet. Each $60 \mathrm{c} ; 10$ for $\$ 5.00$.

\section{BUSH HONEYSUCKLES}

Bella Albida. A handsome new hybrid of strong growth. Flowers white, in great fragrant clusters, followed by attractive ropes of red berries, which remain all summer. 2 to 3 feet. Each 50c; 10 for $\$ 4.50$.

Fragrantissima. Not a showy sort, but its early pink and white flowers are sweetly fragrant, and its foliage remains until late in winter, if somewhat sheltered. 2 to 3 feet. Each $50 \mathrm{c} ; 10$ for $\$ 4.50$.

Grandiflora Rosea. (Pink Tartarian.) Bright pink flowers in abundance, and very fresh, rounded foliage; one of the most noticeable. 2 to 3 feet. Each 50c; 10 for $\$ 4.50$.

\section{HYDRANGEA}

Arborescens Grandiflora. ("Hills of Snow.") The flowers are, in a large way, similar to the familiar "Snowball" in appearance; conspicuousiy white and imposing. July to September. By cutting back to the crown each spring, the bushes may be kept round and dense at a normal height of three to five feet. 2 to 3 feet. Each 60c; 10 for $\$ 5.50$.

Paniculata Grandiflora. Fine tall hedges, or if planted in rich soil and severely pruned every spring before the leaf buds open, will get to be very dense, dwarf clumps of compact form, wonderfully attractive when laden with their massive white plumes. Large beds, kept at a uniform development, are extremely showy; first snowy white, then pink, then reddish bronze and green. August till autumn. 2 to 3 feet. Each 60c; 10 for $\$ 5.50$.

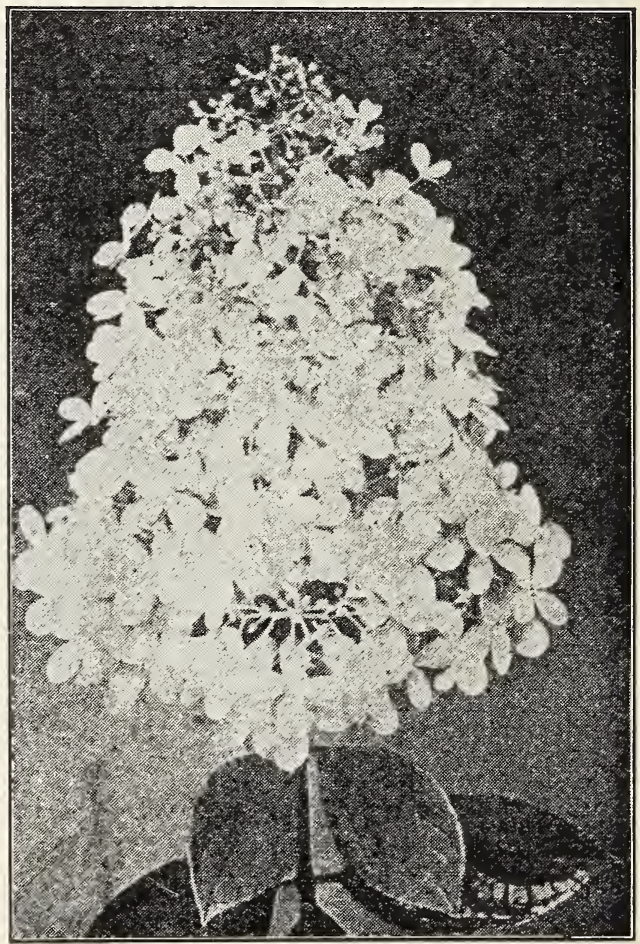

Hydrangea Panioulata Grandiflora 
Ilex Verticillata. (Black Alder or Winterberry.) Although its small June flowers are numerous and foliage darkly lustrous, the sparkling masses of crimson fruits which appear in October represent its greatest charm and carry its value far into Winter. 18 to 24 inches. Each 75c; 10 for $\$ 6.50$.

\section{LILACS (Syringa)}

Common Purple. Most suitable for hedges and the taller shrub groups. 2 to 3 feet. Each 50c; 10 for $\$ 4.50$.

Persian Purple. Dwarf growing with slender branches and narrow leaves; a choice subject for low and medium height foundation planting. 2 to 3 feet. Each 60c; 10 for $\$ 5.50$.

Rothomagensis. (Rouen Iilac.) Grows 10 to 12 feet high; immense reddish-purple panicles in May. 2 to 3 feet. Each 60c; 10 for $\$ 5.50$.

Villosa. Dwarf growth, broad leaved; pinkish lilac flowers in long loose panicles. 2 to 3 feet. Each 75c; 10 for $\$ 6.50$.

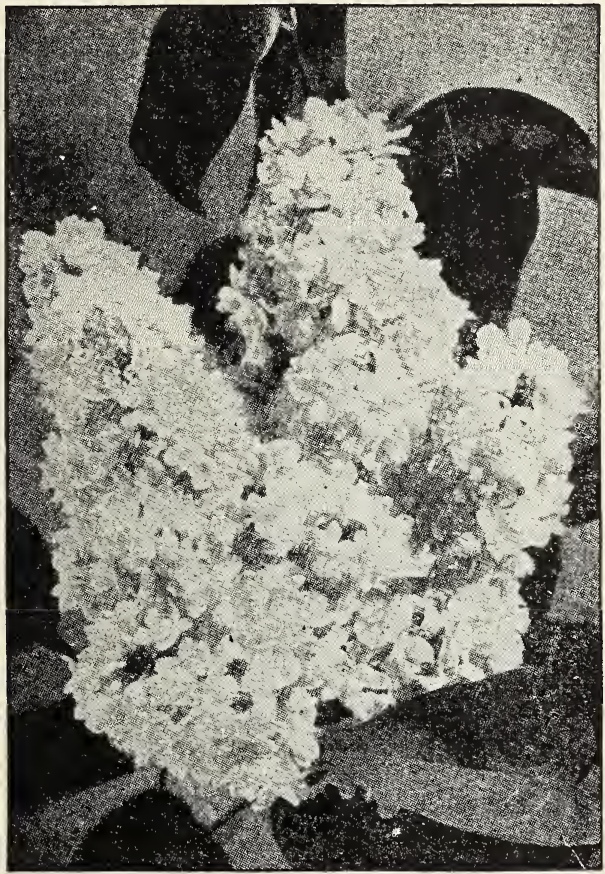

Lilacs (Syringa)

French Named. Double flowering. Improved budded sorts. The bushes are stockier, shorter, of slower growth and more tree-like than other types. In assortment. 2 to 3 feet. Fach $\$ 1.00 ; 10$ for $\$ 9.00$.

\section{PRIVET (Ligustrum)}

Amoor River. (L. Amurense.) A very hardy northern grown type, vigorously upright and tall growing. The leaves are dark green, somewhat lustrous, tardily deciduous. Makes a strong, bold hedge with quite conspicuous bloom in erect white panicles. 18 to 24 inch. 10 for $\$ 1.50 ; \$ 11.00$ per 100. 2 to 3 feet. 10 for $\$ 2.00 ; \$ 16.00$ per 100 .
California. (I. Ovalifolium.) Quick growing, straight, densely clothed shoots; the foliage in precise arrangement, a dark shiny green. The handsomest and most generally used of the entire group for hedging, clipped specimens, or for massing. 2 to 3 feet. 10 for $\$ 1.50 ; \$ 10.00$ per 100 .

Japanese (L. Ibota). Makes up into striking tall clumps, or informal sereening hedges, with widespread curving branches; very vigorous and hardy. 18 to 24 inches, 10 for $\$ 1.50 ; \$ 11.00$ per 100 . 2 to 3 feet, 10 for $\$ 1.80$; $\$ 15.00$ per 100 .

Regel's (L. Regelianum). A strong, very hardy type, with dark and shiny leaves. The numerous branches are stiff, twiggy and horizontally spreading, gracefully drooping at the ends. Makes a naturally wide, dense bush particularly adaptable to foundation plantings. 15 to 18 inches, 10 for $\$ 2.50 ; \$ 20.00$ per 100 . 18 to 24 inches, 10 for $\$ 3.00$; $\$ 27.50$ per 100 .

\section{PHILADELPHUS (Mock Orange)}

Coronarius. (Garland Syringa.) A fine old form, 8 to 10 feet tall, that blooms among the earliest. Its large, showy flowers are delightfully scented and are borne in graceful sprays. 2 to 3 feet. 60c each; 10 for $\$ 5.50$.

Coronarius grandiflorus. The most vigorous species of the group, growing 10 feet high. Its long, irregular branches are clustered with large, slightly fragrant flowers in June. 2 to 3 feet. 60c each; 10 for $\$ 5.50$.

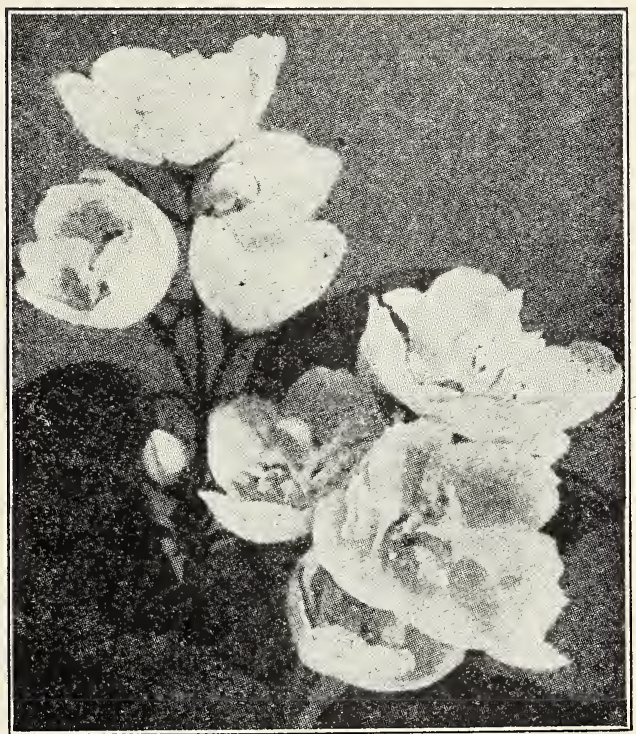

Philadelphus Virginale

Virginale. Because of its own merit this variety has made a place for itself in the family of the Mock Oranges. It is not too much to say it is the best white-flowering shrub offered today. The blooms are pure snowy white, semi-double and double, and borne in the greatest profusion. The plant grows freely and soon will reach a height of 6 to 8 feet. 2 to 3 feet, Each 75c; 10 for $\$ 6.50$. 3 to 4 feet, Each $80 \mathrm{c} ; 10$ for $\$ 7.00$. 
Lemoinei Erectus. A superb up-right-growing shrub with many white fragrant blooms. 2 to 3 feet. $60 \mathrm{c}$ each; 10 for $\$ 5.50$.

Aureus. (Golden Syringa.) Valuable for contrastive grouping, and the best golden leaved shrub. 15 to 18 inches. 60 c each; 10 for $\$ 5.50$.

\section{Rhamnus}

Rhamnus Catharticus. (Buckthorn.) A dense, twiggy bush, 6 to 10 feet high, with dark foliage relieved by masses of attractive white flowers in June and July. Makes a good, prunable hedge. 2 to 3 feet. Each 50 c; 10 for $\$ 4.50$.

\section{SAMBUCUS (Elder)}

Acutiloba. (Cut-leaved Elder.) Great handsome cymes of delicate, white, fragrant flowers in June and July, followed by large clusters of fruit. 2 to 3 feet. Each 50 c; 10 for $\$ 4.50$.

Aurea. (Golden Elder.) Its golden yellow leaves contrast beautifully with the other shrubs. Flowers white, in flat topped cymes. Grows naturally 10 to 15 feet, but can be pruned into a neat, compact little bush. 2 to 3 feet. Each 50c; 10 for $\$ 4.50$.

\section{SPIREA DWARF FORMS}

Anthony waterer. Dwarf, bushy, of spreading type, with large corymbs brilliantly colored rosy crimson. Very free flowering, as its best in late summer. This is one of the few good showy red flowered shrubs sufficiently dwarf to be used in foundation plantings or the low front row of shrub groups. 2 feet. Each $60 \mathrm{c} ; 10$ for $\$ 5.50$.

Wallufi. Blooms in the same broad, graceful panicles, and has the same habit of growth as Anthony Waterer, but retains its depth of color longer, remaining red until flower is old and turns brown. 2 feet. Each $60 \mathrm{c} ; 10$ for $\$ 5.50$.

Callosa Alba. Large flat clusters of white flowers nearly all summer, foliage and growth like above. 2 feet. Each 60c; 10 for $\$ 5.50$.

Froebeli. Dwarf, and similar to A. Waterer, but a trifle taller, with broader leaves. Bright crimson flowers in dense corymbs during July and August. 2 feet. Each $60 \mathrm{c} ; 10$ for $\$ 5.50$.

\section{TALLER SORTS-3 to 10 Feet}

Arguta Multiflora (Snow Garland.) A slender, upright shrub, 3 to 5 feet high, with branches a snowy mass of clear white flowers in early May. 2 to 3 feet: Each 60c; 10 for $\$ 5.50$.

Douglasi. Upright in growth to 7 feet, with reddish brown branches and narrow, oblong leaves. Bears spikes of beautiful deep rose-colored flowers in July. 2 to 3 feet. Each 60c; 10 for $\$ 5.50$.

Opulifolia Aurea. (Golden Spirea.) Of similar habit to above, with young foliage of bright yellow changing to golden bronze in the fall. 2 to 3 feet. Each 60c; 10 for $\$ 5.50$.

Prunifolia f1. pl. (Bridal Wreath.) Plum leaved foliage turning in autumn to very brilliant red. Earliest; with small double white clustered flowers. 2 to 3 feet. Each 60 c; 10 for $\$ 5.50$.

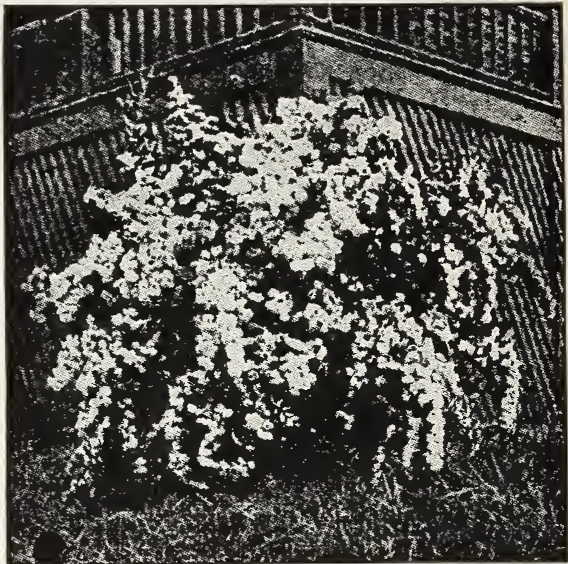

Spirea Van Houtte

Thunbergi. Forms a dense, fluffy bush, 3 to 5 feet high; the feathery foliage, which is a peculiar but pleasing shade of yellowish green, changing in autumn to bright red and orange. 2 to 3 feet. Each $60 \mathrm{c} ; 10$ for $\$ 5.50$.

Van Houtte. Grandest of Spireas, one of the best of shrubs; complete fountain of pure white bloom in May and June. The foliage and bush shape is ornamental the year round. 2 to 3 leet. Each 60c; 10 for $\$ 5.50$.

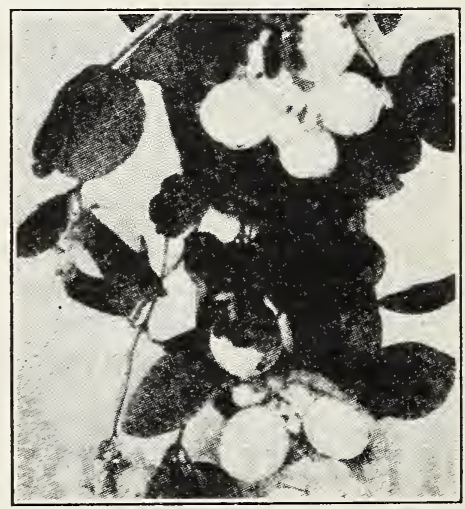

Snowberries

\section{SYMPHORICARPOS}

Snowberry. (S. Racemosus.) Inconspicuous, rose colored flowers in June and July; followed by large clustered, milk white fruits which remain far into winter. The combination of pink flowers and white berries on the same twig is charming. Foliage is rounded, clean and fresh looking, a glaucous green. 2 to 3 feet. Each 60c; 10 for $\$ 5.50$.

Indian Currant. (S. Vulgaris.) Similar to the Snowberry except that its fruits are dull red, and that the smaller berries cluster in thick ropes along the weighted-down stems. 2 to 3 feet. Each 60c; 10 for $\$ 5.50$. 


\section{TAMARIX}

Gallica. Slender, spreading branches, the leaves dull bluish green. Buds are globose, the flowers flesh white in delicately panicled racemes. MayJuly. 2 to 3 feet. Each 60c; 10 for $\$ 5.50$.

Africana. Very graceful shrub with feathery foliage and long, slender racemes of pink flowers in early summer. Very striking at the edge of an evergreen border. 2 to 3 feet. Each $60 \mathrm{c} ; 10$ for $\$ 5.50$.

\section{VIBURNUM}

Carlesii. A valuable recent introduction from Korea, producing its delicate, spice-scented flowers in May and June. The buds before expanding are an attractive pink, developing Bouvardia-like umbels of pure white. Flowers preserve their perfect form and purity of color an unusually long time. 15 to 18 inches. Each $\$ 1.50 ; 10$ for $\$ 14.00$.

Opulus. (European Cranberry.) 8 to 10 feet. Handsome, dense, brilliant green foliage; a rich setting for large bunches of erimson berries which persist on winter bare branches. 2 to 3 feet. Each $60 \mathrm{c} ; 10$ for $\$ 5.50$.

Plicatum. (Japan Snowball.) Erect, compact, growing 6 to 8 feet. Purple tinted foliage of beautiful pattern, spangled with perfect ovoid corymbs of purest white, in June. 2 to 3 feet. Each \$1.00; 10 for $\$ 9.00$. 3 to 4 feet, each $\$ 1.25 ; 10$ for $\$ 11.00$.

Sterilis. ("Snowball" or Guelder Rose.) The common Snowball which helps out so bravely for Decoration Day, with its lovely white balls of bloom. 2 to 3 feet. Each $65 \mathrm{c} ; 10$ for $\$ 6.00$.

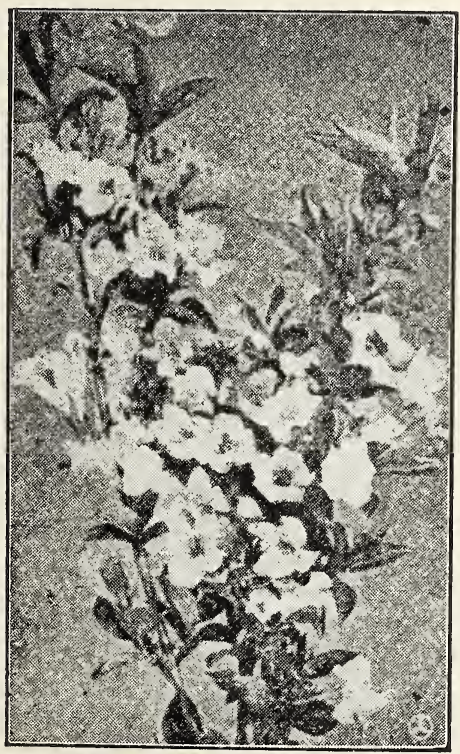

Weigela

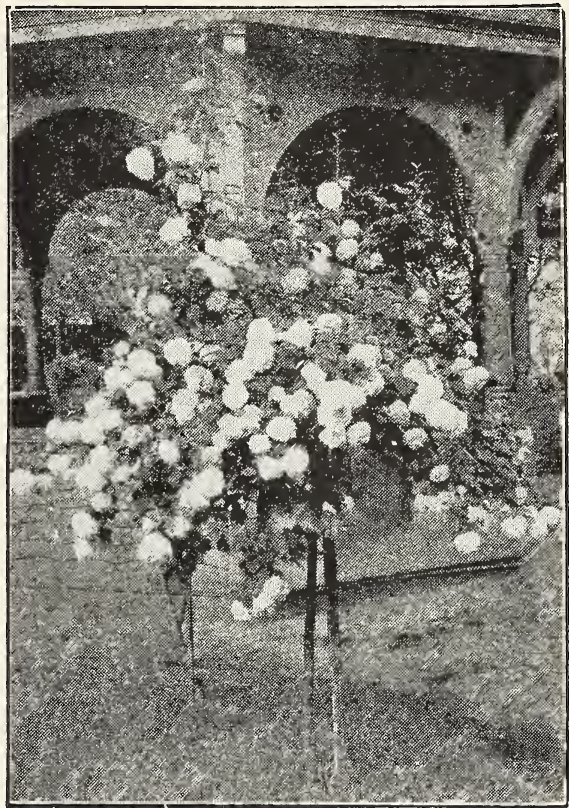

Viburnum Sterilis

Tomentosum. A single flowered form of the Japan Snowball, blooming in large flat umbel-like eymes with marginal white flowers in May. Bush broad and symmetrical, with corrugated bronzegreen foliage, purple hued beneath. Fruits red, changing to blue-black. 2 to 3 feet. Each 60 c; 10 for $\$ 5.50$.

\section{WEIGELA (Diervilla)}

Abel Carriere. Of all the hybrid Diervillas, this is perinaps one of the finest, growing to be a tali shrub 8 to 10 feet high and bearing great quantities of rose-carmine flowers with yellow spot in the throats. It blooms in May and June. 2 to 3 feet. Each $60 \mathrm{c} ; 10$ for $\$ 5.50$.

Candida. 4 to 6 feet; a choice variety blooming in profusion during June and to some extent all summer. Pure white. 2 to 3 feet. Each 60c; 10 for $\$ 5.50$.

Desboisi. One of the darkest and best of the rose colored sorts. 2 to 3 feet. Each 60 c; 10 for $\$ 5.50$.

Eva Rathke. The most distinct and one of the most attractive varieties; flowers deep carmine red. 2 to 3 feet. Each $60 \mathrm{c} ; 10$ for $\$ 5.00$. 3 to 4 feet, each $75 \mathrm{c} ; 10$ for $\$ 6.50$.

Rosea. Most popular of all; tall growing, vigorous, with deep pink flowers in the greatest profusion during June. 2 to 3 feet. Each 60c; 10 for $\$ 5.50$.

Rosea Nana Variegata. Leaves broadly margined creamy white; flowers pink. Dwarf; one of the most useful and choice variegated leaved shrubs. 2 to 3 feet. Each 60 c; 10 for $\$ 5.50$. 


\section{HARDY CLIMBING VINES}

\section{ARISTOLOCHIA (Dutchman's Pipe)}

Sipho (Birthwort). A native species of climbing habit and rapid growth, with very large, heart,shaped leaves and curious pipe-shaped yellowish brown flowers. Each 75c; 10 for $\$ 6.50$.

\section{AMPELOPSIS}

Quinquefolia. (American Ivy or $\mathrm{V}$ irginia Creeper.) A very rapid growing vine covered with heavy digitate leaves affording shade and of great beauty when changing to scarlet in autumn. Each $40 \mathrm{c} ; 10$ for $\$ 3.50$.

Veitchi. (Boston or Japan Ivy.) The now famous Japan or Boston Ivy used so extensively to cover brick or stone buildings. The foliage is dense, completely carpeting a surface, and the autumnal tints of green and red are unsurpassed for beauty. Each 50 c; 10 for $\$ 4.50$.

\section{CLEMATIS}

\section{Large-Flowering Clematis}

Henryi. Flowers creamy-white and very large; a fine bloomer. Each $\$ 1.00$.

Jackmani. This variety is better known than any other, and still stands as one of the best. It is a strong grower, and produces a mass of intense violet-purple flowers four to six inches in diameter, from July until October. Each $\$ 1.00$.

Madam Edouard Andre. Flower/s are a beautiful shade of erimson; a free bloomer. Each $\$ 1.00$. One Each of the Above, 3 for $\$ 2.50$

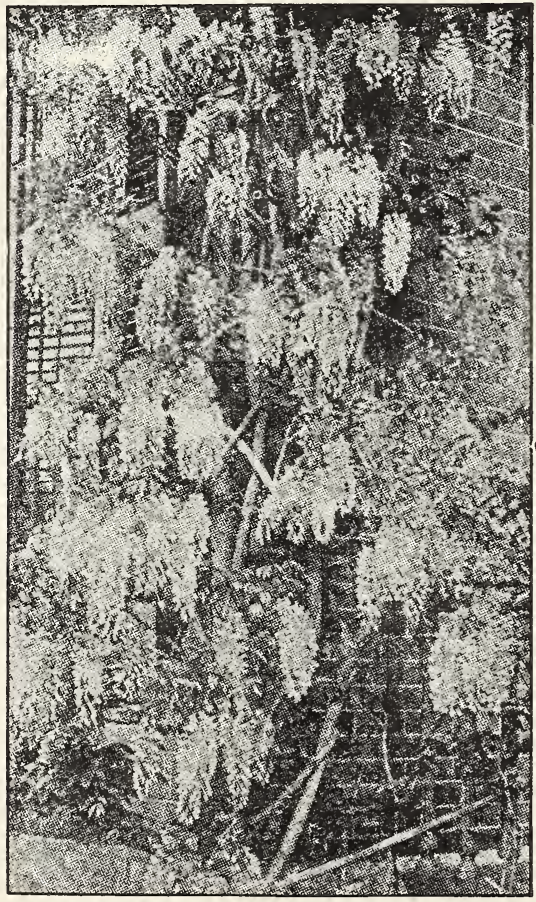

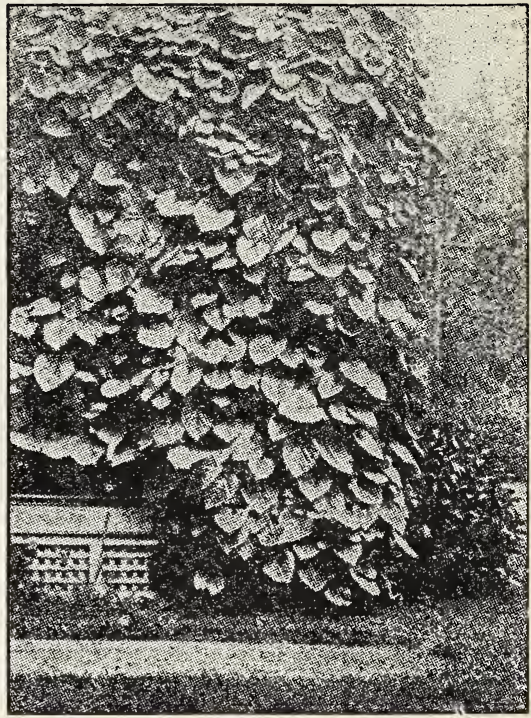

Dutchman's Pipe

Small-Flowering Clematis

Paniculata. A great novelty from Japan. This variety of Clematis has proved to be one of the most desirable, useful and beautiful of hardy garden vines, a luxuriant grower, profuse bloomer, and possessing fine foliage. Each 50c; 10 for $\$ 4.00$.

\section{HONEYSUCKLE (Lonicera)}

Hall's Japan Honeysuckle (I. Halleana). A strong, vigorous vine with pure white flowers, changing to yellow; foliage remains green well into winter; very fragrant and covered with flowers almost the entire season; one of the best bloomers. Each 50c; 10 for $\$ 4.50$.

Monthly Fragrant Honeysuckle. (L. Pericylmenum, var Belgica.) Blooms all summer; flowers red and yellow and very fragrant. Each 60c; 10 for $\$ 5.50$.

Scarlet Trumpet Honeysuckle. (L. Sempervirens.) One of the handsomest in cultivation; a strong, rapid grower; flowers a bright scarlet, not much odor. Each 50c; 10 for $\$ 4.50$.

\section{WISTARIA}

Chinese Purple Wistaria. (W. Sinensis.) One of the best of the Wistarias; rapid growing and elegant, attaining 15 to 20 feet in a season; flowers a pale-blue, borne in long pendulous clusters in May and June. Each 75c; 10 for $\$ 6.50$.

Chinese White Wistaria. (W. Sinensis, Var Alba.) Same as the Chinese Purple, except the flowers are pure white; very beautiful variety. Each $75 c ; 10$ for $\$ 6.50$. 


\section{R O S E S}

Protect for the Winter by covering bed at least 6 inches with leaves or manure; a binding surface of dirt, cornstalks or boughs on top. A convenient method is to confine this dressing by an enclosure of 12-inch chicken wire.

Pruning. Roses are usually shipped with most of their wood, but it is a mistake on the part of many planters to put them in the ground untrimmed. The weak shoots are usually removed by us before sending stock out, so that what the customer gets is all ready to plant except cutting back. Hybrid Perpetual Roses should be cut back, every shoot, to about 6 to 8 inches above the crown or that part above the roots where the stem begins to branch. Teas and Hybrid Teas need not be cut back quite so hard; the Polyanthas not at all unless stems are too numerous. Every Spring, usually the fore part of March, just before the leaf buds begin to swell, these classes should be treated similarly and the winter covering gradually removed. The Rugosas are pruned merely to keep their growth within bounds and to remove dead wood; the Hardy Climbers are merely trimmed, and inasmuch as their bloom comes only on wood made the season before, the safest and most beneficial time for pruning is immediately after their blooming season and before they make new summer growth. Suckers from the Manetti stock should be cut off at once, and may be recognized by a difference in color and arrangement of seven leaves, instead of five, as in almost all varieties of Roses. Do not be afraid of the knife; the flowers will be larger and richer in color, and the bed more sightly.
Treatment on Arrival. If upon arrival the roots seem to be very dry, soak them thoroughly in water; if the stems as well are too dry, bury the entire plant in the ground for two or three days. At no time after unpacking should the roots be exposed to the sun or dry winds; a very little neglect at this time working serious if not fatal injury to the bush.

Planting. In preparing a Rose Bed, select a sunny location guarded from cold north winds, if possible. Dig out the beds to a depth of two or three feet and about three feet in width; then refill the trench with a mixture of soil (any good fertile soil will do) and well rotted cow manure, making provision for good drainage if location is not naturally drained. Time should be allowed for this filling to settle, the final top surface being an inch or two below the edges of the bed. Do not raise the surface of Rose beds above the surrounding surface. They suffer less from drought when left level with the turf. Plant your Roses in the center, being very particular to press and tramp the soil firmly around the roots; and soaking the bed thoroughly at the finish. The Everbloomers may be set 18 inches apart, the Hybrid Perpetuals about 2 feet. After the plants have been set out, keep the soil loose to the depth of an inch or two, by frequent stirrings. An occasional soaking with weak manure water is a great help to Roses of all sorts, and is especially active during the blooming season. Towards the end of July, a mulch of longstrawed manure will aid in preserving what moisture is in the soil during the customary droughts of the "Dog Days."

\section{HYBRID TEA ROSES—Novelties and Recent Introductions}

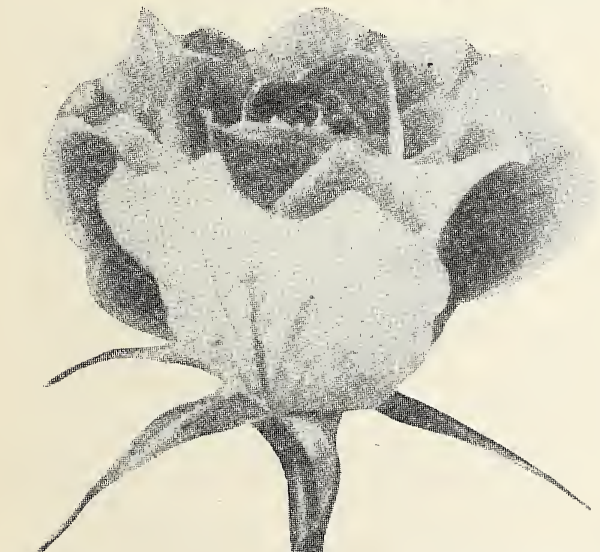

Talisman. This new American Rose, originated by the Montgomery Co. and offered now for the first time, created a sensation at all the shows where it was exhibited last year and was awarded Gold Medals by the American Rose Society at the National Flower Show at Louisville, Ky., at the Philadelphia Flower Festival as well as at the International Flower Show at New York, where it was also honored with the President Coolidge Horticultural Gold Medal. It is the most ramarkable piece of coloring that we know in any Rose; a combination of shadings of gold, apricot, yellow and deep pink or old-rose. The outside of the petals is bright yellow, gold, and pink: as the flower develops and the petals unfold they become bright apricot, gold, deep rose-pink or old-rose and unlike most Roses the color becomes brighter as the flowers develop. The bud is long, perfectly formed, averaging about 25 to 28 petals, the plant is a strong, vigorous grower with glossy green foliage and free flowering. Strong two-year-old plants, ready for delivery. Each $\$ 2.50$; 10 for $\$ 22.50$.

Mrs. Erskine P. Thom. Another season's experience, not only in our own cultures but with the many favorable reports which we have received from customers who have planted this variety during the past two years, convinces us that we are fully justified in our last season's predictions that it would prove the best yellow garden variety yet introduced. It is of clean, vigorous, healthy, bushy habit of growth, almost equal in strength to the best of all bedding roses. Radiance; with ample dark bronzy, green disease resistant foliage. The medium sized buds are long and shapely and develop into fair sized flowers that are full double, of good form, of a rich lemon-yellow, sweetly scented. Very free flowering throughout the season and particularly good in the fall. Each $\$ 1.25 ; 10$ for $\$ 10.00$. 
Five New Hybrid-Tea Roses

Edel. Bud very large; flowers very large, double, well built, stately; open well in all weather; sweet fragrance. Color, white, with the fantest ivory shading toward base, passing to pure white. Foliage bold and distinct. Very vigorous grower; free bloomer. Each \$1.00.

Wm $F$ Dreer. Its coloring is not sharply defined or aggressive, but just that modest deicacy and sweetness found in orchids and certain water-lilies. Soft, silvery shell pink, at times creating a golden illusion through reflection from the base of petals which are definitely gilded. A magnificent vase type, at its best as buds, and when half expanded. Each \$1.00.

Charles $K$. Douglas (H, T.) Bud large, long pointed; flower large, full, double, sweet fragrance; color, intense flaming scarlet, flushed bright velve y crimson. Foliage dark green disease resis'ant; vigorous, upright grower produces an abundance of blooms from June to October. Each $\$ 1.00$.

Mrs. William C. Eæan (Per.) Strong, healthy grower, with long pointed buds which develop into flowers of good shape. In color, it is a two-tone pink, the reverse of the petals a soft light pink, the interior deep flesh color with a golden line at the base of the petals; the flowers are carried on long stiff stems, and last in good condition for an unusually long time, either cut or on the plant; an exceptionally free and continuous bloomer. Each $\$ 1.00$.

Mrs. C. W. Edwards (H. T.) Bud large, long-pointed; flower very large, double, high centered; pure crimson-carmine, yellow base, on the outside of the petals the yellow bases run in $^{+} \mathrm{o}$ veinings of yellow; moderate fragrance. Profuse and continuous bloomer. Hardy. Each $\$ 1.00$.

SPECIAL OFFER-One strong twoyear-old plant, each of the 5 varienies offered above by mail for $\$ 4.00$.

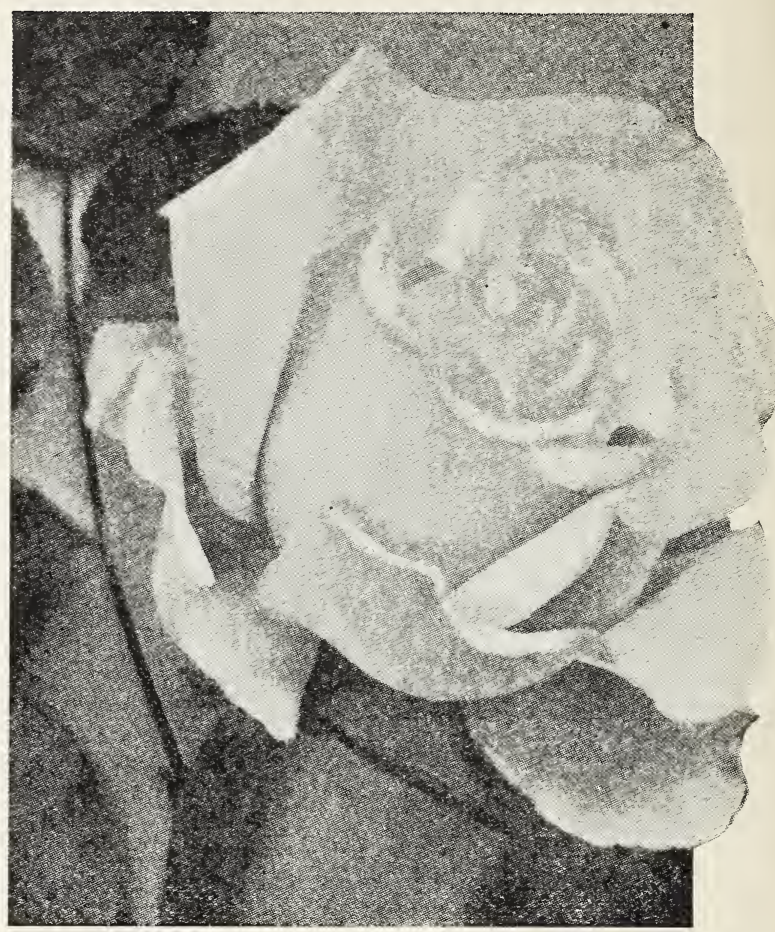

Edel

\section{EVERBLOOMING HYBRID TEA ROSES-Two Year Field Grown}

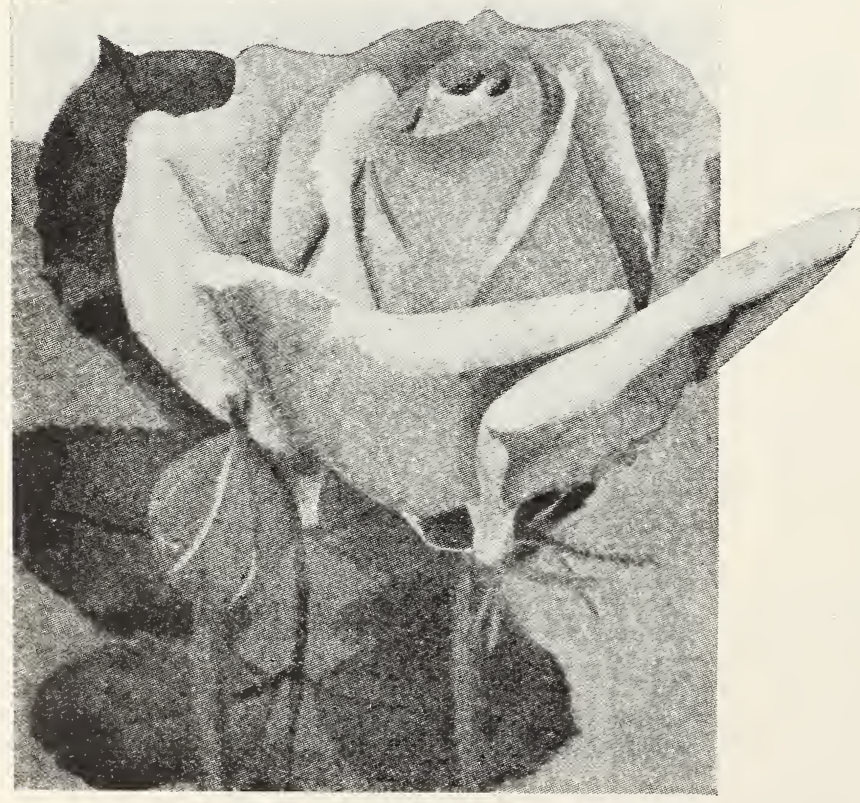

Duchess of Wellington
Columbia. A beautiful, true pink; deepening as it matures to a warm, glowing tone, which is enduring. Its usual double petalage and substance make it a good summer Rose, while the great size, color and long (almost thornless) stems mark it as a superior eutting variety. Each 90c; 10 for $\$ 8.50$.

Duchess of Wellington. Long, shapely buds, with petals of great substance, color an intense saffron-yellow, stained deep crimson, delightfully fragrant and very free flowering. Each $\$ 1.00 ; 10$ for $\$ 9.00$.

Edward Mawley. Dazzling crimson scarlet, exquisitely perfumed. One of the grandest red roses ever offered, either for cutting or bedding. Each $90 \mathrm{c} ; 10$ for $\$ 8.50$.

Gen. McArthur. An ever-blooming rich crimson rose which has long held first place as a popular cut rose. A most lovely flower. Each $90 \mathrm{c} ; 10$ for $\$ 8.50$. 
Grus An Teplitz. (H. T.) (Greeting to Teplitz.) Hardy in all sections; grows freely to height of four to five feet; vivid, dazzling, fiery crimson; sweetly fragrant. Each 90c; 10 for $\$ 8.50$.

Lady Hillingdon. Medium to large, deep apricot-yellow, beautiful in bud and flower. Each $90 \mathrm{c} ; 10$ for $\$ \mathbf{8 . 5 0}$.

Los Angeles. Gloriously living up to its recent novelty introduction which claimed the California product to be one of the grandest all-round Roses of American origin ever put on the market. The stems are long as American Beauty; the flowers are large as Paul Neyron; its freedom and continuance of bloom are remarkable; its color a flame pink, toned with coral and shaded with translucent gold at the base of the petals. Each $\$ 1.00 ; 10$ for $\$ 9.00$.

Lyon. An unusually large and remarkably full flower: with huge reflexed petals of handsome shrimp pink, toning to salmon pink on edges and chrome yellow at base; flowers frequently five inches across when fully expanded and very fragrant. Each 90c; 10 for $\$ 8.50$.

Madame Butterfly. A symphony of white, bright pink, apricot and gold. Compared with Ophelia, this derivation is fuller-petaled, more prolific and of greater color appeal. The buds are rich Indian red, yellow at base. Each $90 \mathrm{c} ; 10$ for $\$ 8.50$.

Madam Edouard Herriot. Buds coral red with shades of yellow and rose, passing to shrimp red. Words do not convey an adequate idea of the wonderful coloring of this great rose. It has been described as colored like sunshine on a copper red metal. Each $90 c ; 10$ for $\$ 8.50$.

Mrs. Aaron Ward. Buds are deeply cupped, the open flowers delightfully attract ve. Color, deep golden orange, shading outward to creamy yellow. Each 90c; 10 for $\mathbf{\$ 8 . 5 0}$.

Radiance. Extra hardy, vigorous and prolific; one of the best all-round Garden Roses. Its color is a beautiful blending of carmine-rose with shades of opal and copper. Each $90 \mathrm{c}$; 10 for $\$ 8.50$.

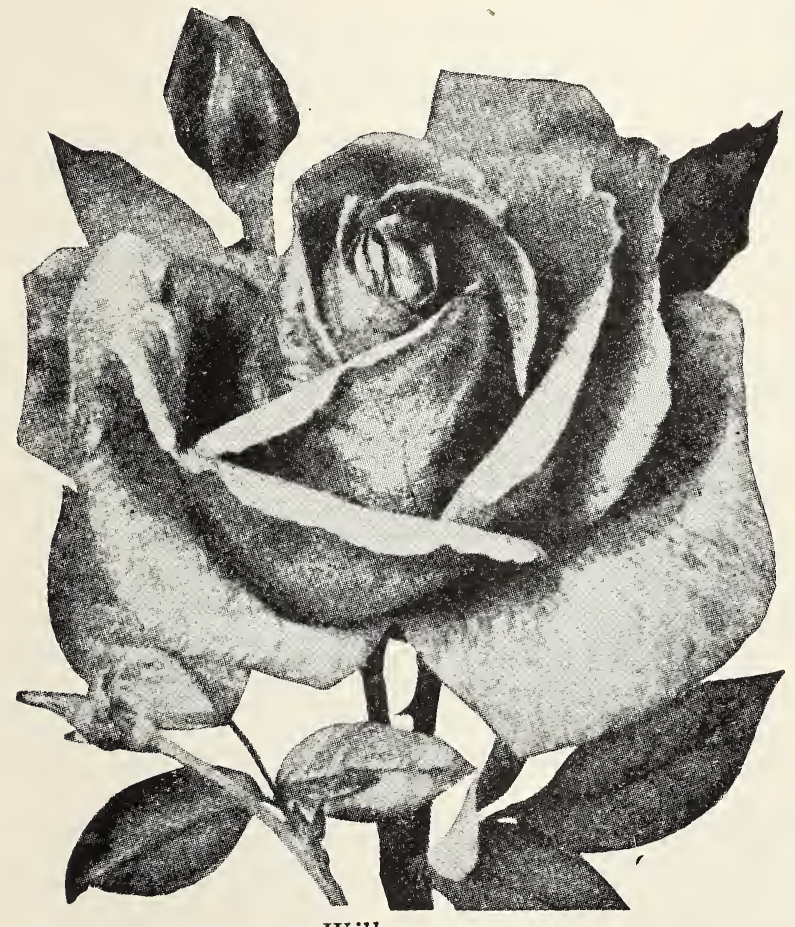

Willowmere

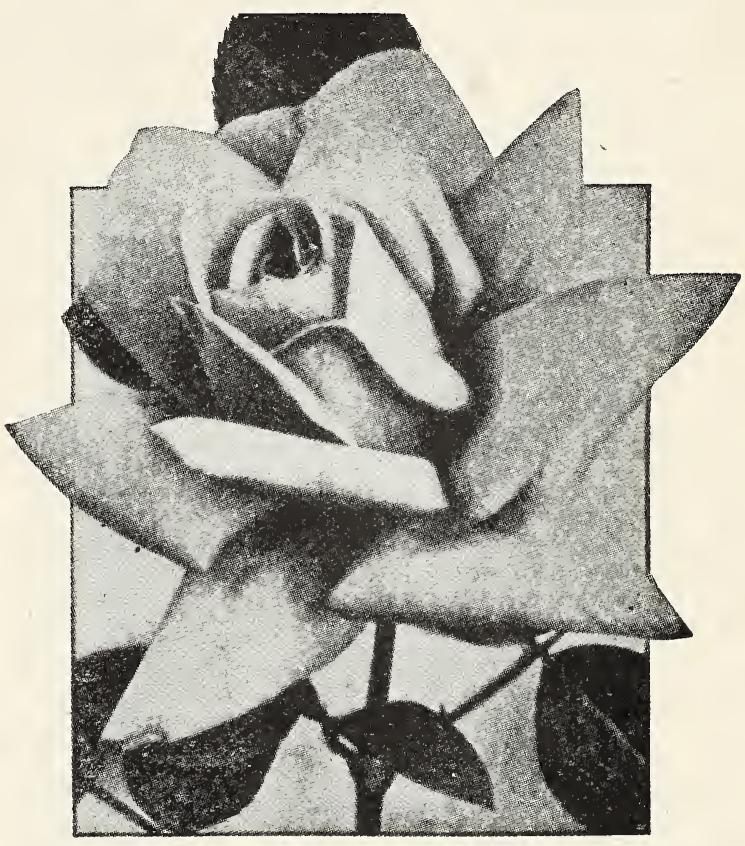

Los Angeles

Red Radiance. The globular, heavy-stemmed "Radiance" duplicated in all respects except color; this sport form being a brilliant crimson. Each 90c; 10 for $\$ 8.50$.

Ophslia. One of the most beautiful and popular of recent cut-flower favorites; with perfect flowers of distinct form, lavishly produced, smitting the exquisite perfume of the Richmond type; white tinted salmon flesh and shaded with rose, a strong glow of yellow at base. Each $90 \mathrm{c} ; 10$ for $\$ 8.50$.

Souv. de Claudius Pernet. This fine variety maintains its reputation as one of the most reliable and strongest yellow roses ever introduced. Its color is a decided and unstained sunflower yellow even deeper toned at center. Unlike most yellows, hot wea ${ }^{4}$ her and exposure have li tle effect upon its pigments; the matured flower gleaming as richly as when first unfolding. Its flower form is large and full, the buds long and pointed. Vigorous, erect and branching, with brilliant foliage and almost thornless stems. Each $\$ 1.00 ; 10$ for $\$ 9.00$.

White Killarney (Double). This is the best known of Dicksons famous Irish Hybrid-Tea Roses, and is one of the most popular of our garden roses. In color it is clear white, whiter than any other rose, the fragrant blooms are large, the buds long and pointed, the petals very large and of great substance, blooms continuously from June until frost. Each 90c; 10 for $\$ \mathbf{8 . 5 0}$.

Willowmere, Per. Long, carmine coral red bud, large open-cupped flowers, chrome yellow at base, shaded shrimp, toning to carmine rose at edge of petals. A seedling from Lyon, but a more vigorous grower. Each $90 \mathrm{c} ; 10$ for $\$ 8.50$. 


\section{Hybrid Perpetual or Remontant Roses}

These are the "June Roses"' so admirably suited for garden culture, the formation of Rose beds, hedges, etc. In June and July these lovely roses are brilliant with large perfumed flowers of richest colors, are exceeding the Everblooming class in size and vivid effects.

Baby Rambler. A dwarf (bush) form of Crimson Rambler, and furthermore, ever-blooming. Will bloom continuously throughout the summer if planted out of doors. Each 85c; 10 for $\$ 8.00$.

Frau Karl Druschki. (The White American Beauty, or Queen.) An everywhere hardy, vigorous grower, with bright green leaves, delicately veiled; splendid long buds and magnificent snowwhite blossoms, with large saucer-shaped petals. Rightly named and deservedly a prize-winner. Each 90c; 10 for $\$ 8.50$.

General Jacqueminot. The famous red garden Rose. Its unusually fragrant flowers are a brilliant, glowing crimson, not very full, but large and extremely effective. The best known of all red
Roses. Each 85c; 10 for $\$ 8.00$.

Mrs. J. H. Laing. A favorite sort; satiny flowers of soft, clear pink, remarkably free and continuous. Has always been one of the "six best sellers," and generally accepted as among the best of light pinks. Each 85c; 10 for $\$ 8.00$.

Soleil D'Or. Its color is a decided and unstained sunflower yellow, even deeper toned at center. Unlike most yellows, hot weather and exposure have little effect upon its pigments; the matured flower gleaming as richly as when first unfolding. Each $85 \mathrm{c} ; 10$ for $\$ 8.00$.

Paul Neyron. One of the finest hardy Roses ever grown. It blooms unceasingly from June to November, on long, smooth, thornless stems, furnishing a great quantity of uniformly shaped flowers 4 to 6 inches across. Color a bright ruddy pink. This sort is also a dependable fall bloomer, keeping pace with the lovely white Druschki during September and later. Each 85c; 10 for $\$ 8.00$.

\section{HARDY CLIMBING ROSES}

Crimson Rambler. Very vigorous, growing eight to ten feet a season after it is well established. Entirely hardy and extremely prolific. It blooms in clusters. Of a beautiful crimson color and lasts a long time. Each 80c; 10 for $\$ 7.50$.

Climbing American Beauty. Its name is somewhat misleading, but it is one of the best climbing Roses; a strong, healthy, vigorous grower, frequently making shoots from 10 to 12 feet long, and good sized flowers for a climbing Rose that blooms so freely; color, rich rosy crimson, of splendid form and good substance. Each 90c; 10 for $\$ 8.50$.

Dorothy Perkins. A most valuable Pink Rambler Rose. Flowers are very double, of large size, usually two inches across, and borne in loose clusters. Each $80 \mathrm{c} ; 10$ for $\$ \mathbf{\$ 7 . 5 0}$.

\section{NEW HARDY CLIMBING ROSES}

Doctor Van Fleet. One of the newer type of climbers which combines absolute hardiness with flowers large as in the Tea and Noisette class. This variety shows a mass of beautiful clustered buds, which open out into large, shapely flowers; delicate flesh white. Admirable cutting variety with stems 12 to 18 inches long. Each 90c; 10 for $\$ 8.50$.

Emily Gray. In this we have a real yellow climbing Rose as hardy as Dr. Van Fleet. The buds are long and pointed, of splendid shape; in color a beautiful light orange-yellow changing to pale orange as they expand; they are borne on stiff stems of sufficient length for cutting; these stems are of a crimsonred color which together with the unusually dark green, glossy, holly-like foliage, adds a charm to the flowers and makes the plant, even when out of bloom, a most ornamental subject. Each $90 \mathrm{c} ; 10$ for $\$ 8.50$.

Paul's Scarlet Climber. No other climbing Rose can compare with this for brilliancy of color, which is maintained until the petals fall. The flowers, a vivid scarlet, are of good size, semidouble, very freely produced in clusters of from 3 to 20 flowers each on much branched canes, the plants being literally covered from top to bottom with bloom. It is of strong climbing habit and perfectly hardy. This is one of the most popular cilimbing Iioses. Each $90 \mathrm{c} ; 10$ for $\$ \mathbf{8 . 5 0}$.

Silver Moon. Different from all other Roses, with beautiful semi-double flowers four and a half inches and over in diameter; pure white in color, petals of great substance, beautifully cupped, forming a Clematis-like flower. The large bunch of yellow stamens in the center adds to its attractiveness. Each 90c; 10 for $\$ 8.50$. 


\section{New Hybrid Rugosa Roses}

Red F. J. Grootendorst. This might properly be ealled a Rugosa Baby Rambler, it being a cross between Rugosa and the crimson Baby Rambler. Imagine a shrub-like Rugosa Rose covered with trusses of crimson Baby Rambler Roses and you will have a fair conception of this new hybrid variety. It is not a Rose that you want to plant in with your bed of Hybrid-Tea or Hybrid Perpetual Roses, but is valuable to plant as an isolated specimen or in a mass in a bed in an exposed position or in the shrubbery border or use it for an everblooming hedge for which purpose it is admirably adapted. It is absolutely hardy and continues in bloom until late in the fall. Each $\$ 1.00 ; 10$ for $\$ 9.00$.

Pink F. J. Grootendorst. Identical with the above variety, except in color, which is a splendid clear pink. Each $\$ 1.00 ; 10$ for $\$ 9.00$.

Hansa. A showy hybrid. with abundant large, double, reddish-violet flowers; rampant growth. Each $\$ 1.00 ; 10$ for $\$ 9.00$.

\section{Rosa Rugosa Hybrids}

Blanc Double de Coubert. Purest paper-white, blooming in clusters of from five to ten flowers; double; very sweet. A strong rampant grower, having the true Rugosa foliage. Flowers nearly 5 inches in diameter, produced freely and lasting well. Fach $\$ 1.00 ; 10$ for $\$ 9.00$.

\section{Rosa Rugosa}

They should be planted for their foliage alone, as they form good sized bushes 4 to 6 feet high, and their leaves are quite attractive. In June they are covered with myriads of single flowers, and late in the summer bright colored seed-pods give them color. Good for massing with shrubs.

Rubra. The typical Rugosa Rose, with large, single, crimson flowers followed by scarlet hips. The foliage is beautifully crinkled. Each $85 \mathrm{c} ; 10$ for $\$ 7.00$.

Albra. Pure white, with typical Rugosa foliage and orange hips. Each $85 c ; 10$ for $\$ 7.00$.

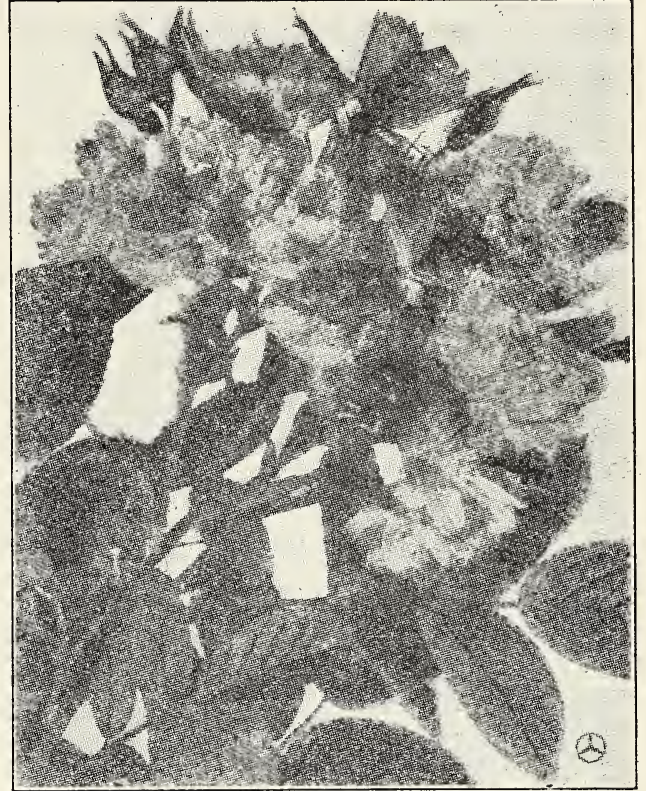

F. J. Grootendorst

Hugonis. A striking, unique, attractive shrub; at home in medium sections of the landscape groups, or conspicuously independent as solitary lawn clump. Last year's canes produce the crop of bloom, with clean, healthy foliage of the Briar type; but the new growth springing abundantly from the roots, is densely clothed in acacia-like leaves and bristles, all a reddish maroon. A matured bush may attain 6 feet in height, with corresponding spread. The sparkling buds begin to swell in April, so that early in May, Hugonis is a shimmering mound of gold. The flowers are single, flat to cup shaped, with charming-stamen tufts at center; set snugly full length of the arching canes. Their color is bright and noticeable, ranging from deep gold, to canary. Each $\$ 1.00 ; 10$ for $\$ 9.00$.

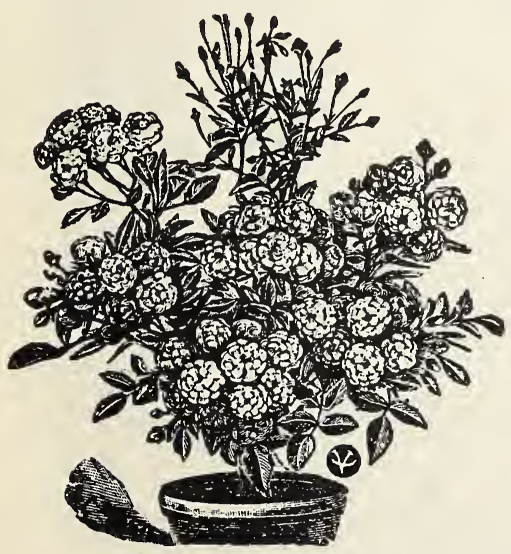

Baby Rambler

\section{POT GROWN EVERBLOOMING ROSES}

Bride. A fine pure white cut flower rose. Very double. Buds are of very large size, earried high and erect; unsurpassed for purity and whiteness. Large two-year-old plants, each 70c; 10 for $\$ 6.00$,

Gruss An Teplitz. One of the richest colored roses known. When first opened it is a dark, rich erimson, quickly ehanging to a bright scarlet. Blooms continually. Two-year-old plants, each 70 c; 10 for $\$ 6.00$.

Hermosa. An old favorite variety. Prized for its beauty and abundant blossoms. Never out of bloom during the summer. Twoyear-old plants, each 70c; 10 for $\$ 6.00$.

Perle Des Jardins. Buds long and pointed, of a deep yellow on first opening, changing to almost clear yellow. Two-year-old plants, each 70 c; 10 for $\$ 6.00$.

Crimson Baby Rambler. Dwarf Baby Rambler. Greatest bedding and pot plant. Two-year-old plants, each 75c; 10 for $\$ 6.50$. 


\section{Hardy Perennial Plants}

THESE can be used to best advantage in groups and beds on the lawn, as borders for drives, walks, 1 or in frout of shrubbery and in the garden. Some of the tall-growing sorts may be planted in among the shrubbery with good effect. Soil should be kept well fertilized. A light covering of coarse, strawy manure or something that will not pack is beneficial in winter.

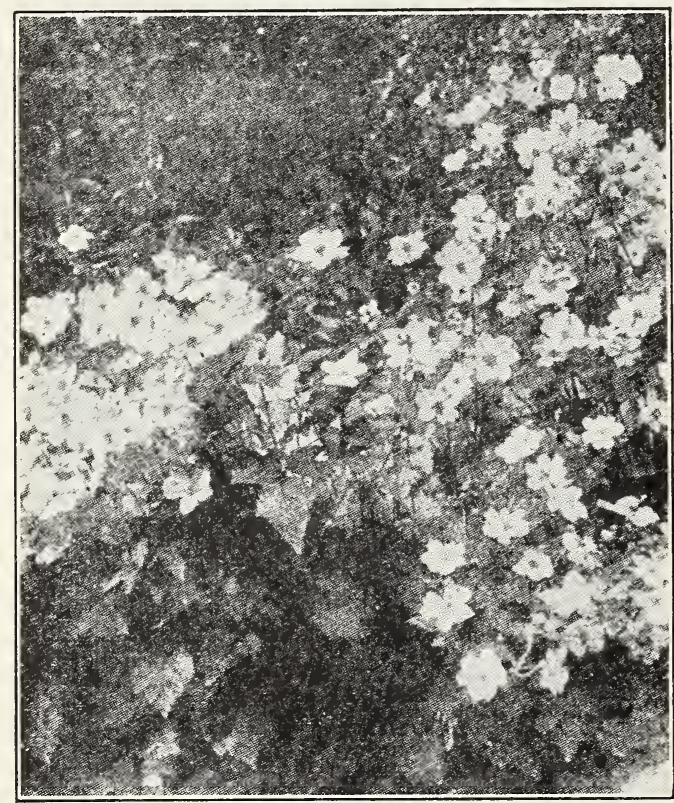

Anemone Japonica Alba

Achillea, Boule de Niege. (Ball of Snow.) A new form, more erect and compact, with fuller ball shaped flowers; snow white. Each 20c; 10 for \$1.75.

Alyssum Saxatile Compactum. (Golden Tuft.) A useful little border and rockery plant, growing not over 12 inches high; covered with enveloping flat clusters of bright golden-yellow flowers early in summer. Each 20c; 10 for $\$ 1.75$.

Anemone Japonica. (Wind Flowers.) 2 to 3 feet. The blooming period extends from August till midNovember, the large open flowers furnishing abundant eut-flowers and a brilliant field display. Each 20 c; 10 for $\$ 1.75$.

Aquilegia (Columbine). One of the showiest and most desirable of the hardy garden plants; especially suitable for rock-work, at the base of foundation walls and under trees. Bloom in early spring. Each 20c; 10 for $\$ 1.75$.

Hardy Asters. The "Michaelmas Daisies" are very largely used by landscapers, to provide masses of foliage and bloom throughout the fall. They give a wide range of selection as to height, character, season and color. Each 20c; 10 for $\$ 1.75$.

Boltonia. (False Chamomile.) Bushy plants, 5 feet high, with Aster-like flowers, profusely covering the entire plant during late summer. Each 15c; 10 for $\$ 1.20$.

Chrysanthemums. Colorful show flowers. Hardy autumn varieties, large flowered types in color. Each 20c; 10 for $\$ 1.75$.
Campanula. (Bellflowers.) Its various types are among the most beautiful border plants in cultivation, very free of bloom, and adapted to any garden soil. Each 20c; 10 for $\$ 1.75$.

Coreopsis Lanceolata Grandiflora. Flowers are rich golden yellow, borne in great profusion nearly the entire summer. This is one of the most serviceable and dependable perennials, furnishing a prodigious amount of excellent cut flowers, besides taking an important place among the 18 to 24 inch border types. Each 20c; 10 for $\$ 1.75$.

Shasta Daisy. (Alaska.) Pure white with yellow eye. Plants are extremely productive of bloom, making as spectacular a field show and as prolific a cut flower supply as any hardy perennial grown. Each 20c; 10 for $\$ 1.75$.

Dicentra. (Bleeding Heart.)-Spectabilis. One of the most delightful of all the early spring flowering plants, bearing numerous rosy red, heartshaped flowers in drooping racemes. Two feet. Each 50 c; 10 for $\$ 4.50$.

\section{Delphinum}

(Perennial Larkspur.) Indispensable to the herbaceous garden. Their long, showy spikes of flowers persist from June till frost and furnish the most satisfactory blues to any color scheme.

Belladonna. A magnificent new sort, unrivalled for continuance of bloom, with large spikes of the most delicate turquois-blue. July till frosts. Each $20 \mathrm{c} ; 10$ for $\$ 1.75$.

Gold Medal Hybrids. Plants vigorous, free blooming, with flower spikes 2 feet long. Grand assortment of colors ranging from lightest blue to purple. Each 25c; 10 for $\$ 2.25$.

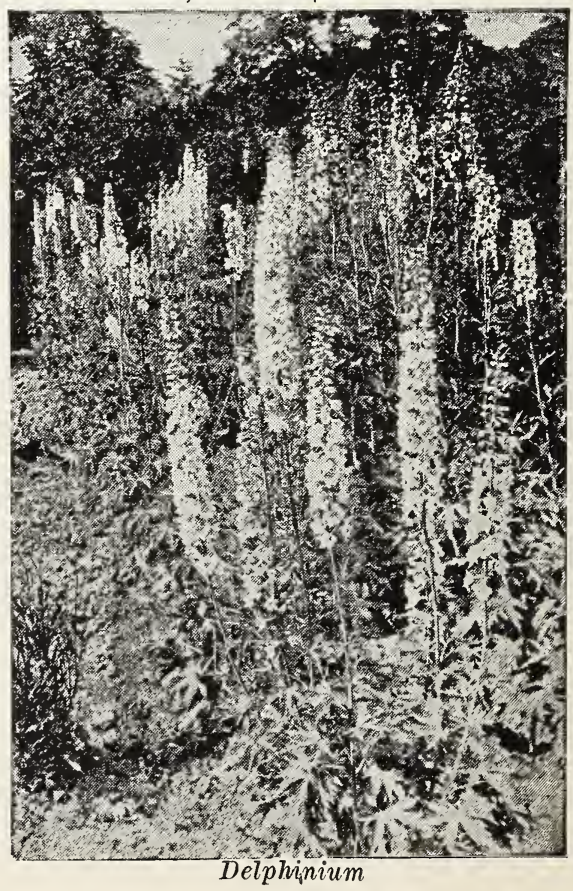


Digitalis. A grand display of thimbleshaped flowers in immense spikes during July and August. Tall growing, with large, rough foliage. Separate colors. Purple, White or Rose. Each 20c; 10 for $\$ 1.75$.

Funkia Glauca. Large oval leaves, with long racemes of pale lilac, funnel-shaped flowers. Each 20c; 10 for $\$ 1.75$.

Undulata Variegata. Graceful leaves having a fluted white edge. Makes a splendid edging for other plants with plainer foliage. Each 20c; 10 for $\$ 1.75$.

Gaillardia Grandiflora Superba. (Blanket Flower.) Makes one of the most gorgeous and prodigal displays of all perennials. Flowers often measure 3 inches in diameter, on clean, 2-feet stems. A hard center of deep maroon is thickly bordered by petals of orange and yellow, ringed by circles of crimson, red and maroon. Each 20c; 10 for $\$ 1.75$.

New Double-flowering Gypsophila. ("Bristol Fairy.") The well-known double-flowering Gypsophila Paniculata, when first introduced, was quite a sensational novelty, and is still one of the most valuable hardy garden plants, with its great panicles of white flowers so indispensable for cutting in July and August. Each $35 \mathrm{c} ; 10$ for $\$ 3.00$.

Gypsophila Paniculata. (Baby's Breath.) Very slender stemmed but bushy. 2 to 3 feet. Good for eutting as well as for borders. Flowers are minute but myriad, pure white, produced in immense fleecy panicles during Aug.-Sept. Each 20c; 10 for $\$ 1.75$.

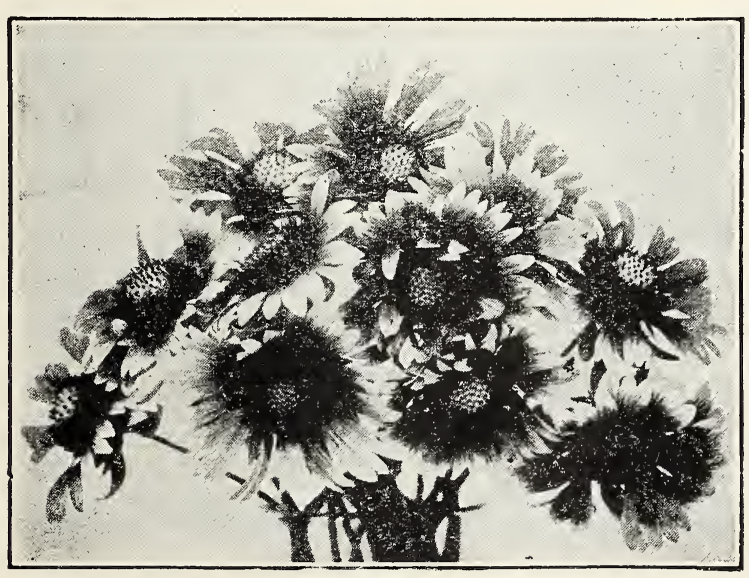

Caillardia

Hibiscus (Mallow). Crimson Eye. Of quick, shrubby growth to 5 feet, bearing quantities of large open flowers like single Hollyhocks; white with prominent crimson throat. Each 20c; 10 for $\$ 1.75$.

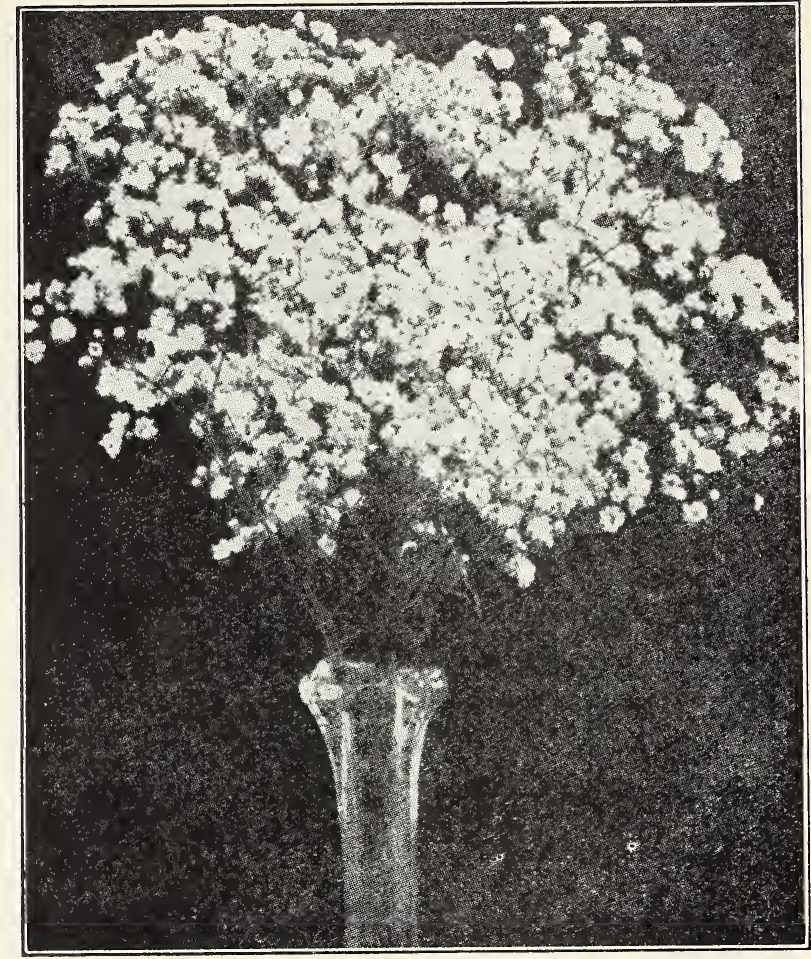

Double Flowering Gypsophila

Mallow Marvels. A giant race derived from the common native Hibiscus, which has elevated this type almost to the dignity of shrubs. Massed in great groups or generously interspersed with shrubs, these "Marvels", grow very rapidly, sometimes getting up to 8 or 10 feet in height; with plenty of broad foliage to furnish a rich setting for the mammoth flowers. Each 20c; 10 for $\$ 1.75$.

\section{Hollyhocks}

This stately old plant is truly " King of the Garden.', Hollyhocks inject so much color and life and picturesqueness into tall backgrounds with their gorgeous, densely-set pillars ranging in height from 4 to 7 feet, ablaze throughout the summer.

Double Flowered. Large rosettes of paperlike tissue, very compactly layered. We offer them in the following separate colorscrimson, black, yellow, white, maroon and pink. Each 20c; 10 for $\$ 1.75$.

German Iris. (Irish Germanica.) The "Fleur de Lis" of France, with exquisite, haunting fragrance; second only to the Peony in perennials. Capable of establishment in any kind of soil, they will attain greater perfection of growth and flowering in a damp, or marshy situation. Each 20c; 10 for $\$ 1.75$.

Japan Iris. (Iris Kaempferi.) Last of the wonderful Iris procession in point of season; but for size of plant and flowers, shapeliness, richness of coloring, beauty of pattern, and splendor of general effect, is unquestionably accorded first. The $r$ flowers are generally rather flat and wide, often measuring 10 to 12 inches across, appearing in great profusion during June and July after the Germans are through. Each 30c; 10 for $\$ 2.50$. 


\section{LILIES}

Auratum. (Gold-banded Japan Lily.) Considered by many the finest of all hardy Lilies. Flowirs very large, made up of broad white petals, thickly studded crimson maroon with a bright golden band through the center of each petal. As the bulbs acquire age and strength, the flowers attain their maximum size and number. Stalks from good sized bulbs frequently have from 12 to 15 flowers. Each $35 \mathrm{c} ; 10$ for $\$ 3.00$.

Candidum. One of the hardiest sorts; pure white. Each 30 c; 10 for $\$ 2.50$.

Longiflorum Giganteum. A well-known beautiful variety, with snow-white trumpet-shaped flowers that are very fragrant. It is quite hardy and blooms freely in the open ground in June and July. Is also used largely for forcing for the Easter holidays; the flowers have more substance and last longer than the Bermuda Lily. Each 45c; 10 for $\$ 4.00$.

Tigrinum, fl. pl. (Double Tiger Lily.) Bright orange scarlet with dark spots, a strong growing, showy variety, and entirely hardy. Succeeds well everywhere. Each 25c; 10 for $\$ 2.00$.

Speciosum Rubrum. White beautifully spotted red flowers in August. Each 35c; 10 for $\$ 3.00$.

Speciosum Album. Very fragrant large flowers, pure white with a green band running through the eenter of each petal. One of the best. Each 35c; 10 for $\$ 3.00$.

Regale. (Myriophyilum.) This new variety from Western China is admittedly one of the most beautiful Garden Lilies yet introduced. It grows 3 to 5 feet high, and blooms out of doors in July. It ist

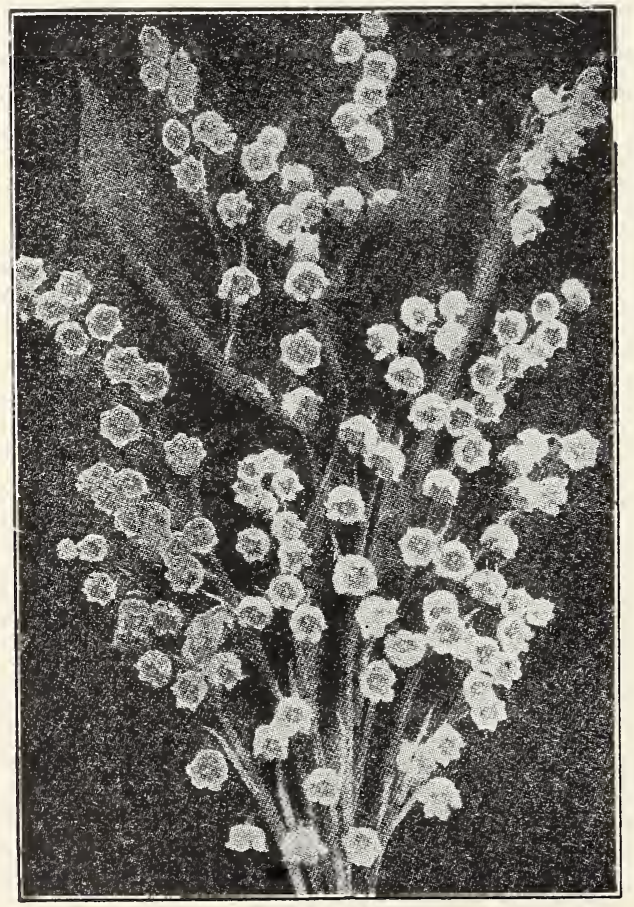

Lily of the Valley

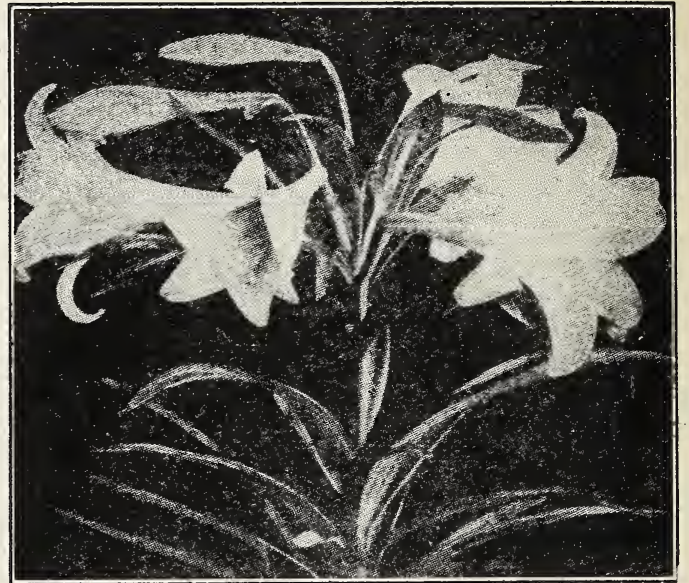

Regale

perfectly hardy, and flourishes under very varied conditions, the large, trumpet shaped, delicately scented flowers, which are produced freely, are ivory-white, shaded pink, tinged with canary yellow at the base of the petals. Strong flowering bulbs. Each 50c; 10 for $\$ 4.50$.

Lily of the Valley. Very small and sweet ar 1 dainty; the creamy white escalloped bells pendant along slender stems. They make up (with their broad shiny leaves) into dainty bouquets of fragrance. They spread actively from the roots and soon reclaim shaded, cold ground which otherwise would be cheerless and barren. Holland Pips. 10 for $60 \mathrm{c} ; 100$ for $\$ 5.00$.

Lobelia Cardinalis. (Cardinal Flower.) Inteuso cardinal-red flowers arranged in stocky spikes 15 to 18 inches long, keep the plant aflame throughout August and September. Naturalizes easily in widely varied soils and degrees of lighth and moisture. Each 20c; 10 for $\$ 1.75$.

Iychnis-Chalcedonica (Maltese Cross). Heartlobed stars of brightest vermilion, arranged in large panicles. $21 / 2$ feet. Each 20c; 10 for $\$ 1.75$.

Myosotis Palustris. The true "Forget-Me-Not," appealing in its modest azure beauty, and cherished for its sentiment. Bushes up to 18 inches high and blooms profusely during early summer. Each 20c; 10 for $\$ 1.75$.

Hardy Myrtle (Vinca Minor). A trailing evergreen plant used extensively for carpeting the ground under shrubs or trees where it is too shady for grass or other plants to thrive. Each 20c; 10 for $\$ 1.75$.

Papaver Orientale. Brilliant "Oriental Poppy" with immense, flaming flowers of orange scarlet. These impressive color blotches are supreme among prevailing greens of early spring. Each 25c; 10 for $\$ 2.25$.

Nudicaule. The "Iceland Poppies" bloom with extravagant freedom during early summer, and in lesser degree throughout; two-inch saucer-shaped flowers, on slender stems, making delightful bouquets, as well as a vivid garden show. Orange, White and Yellow. Each 25c; 10 for $\$ 2.25$.

Pentstemon. Border and rockery plants of long summer blooming season, the flowers somewhat resembling Foxglove, in uncrowded upright spikes. Each 25c; 10 for $\$ 2.25$. 


\section{Peonies-The Queen of the Garden}

NO flowers exceed the Peonies in popularity, and none are more easily grown. They are seldom attacked by insects or disease, and are perfectly hardy, requiring no covering in the severest weather. They thrive in all kinds of soil and flourish in a rich, deep loam.

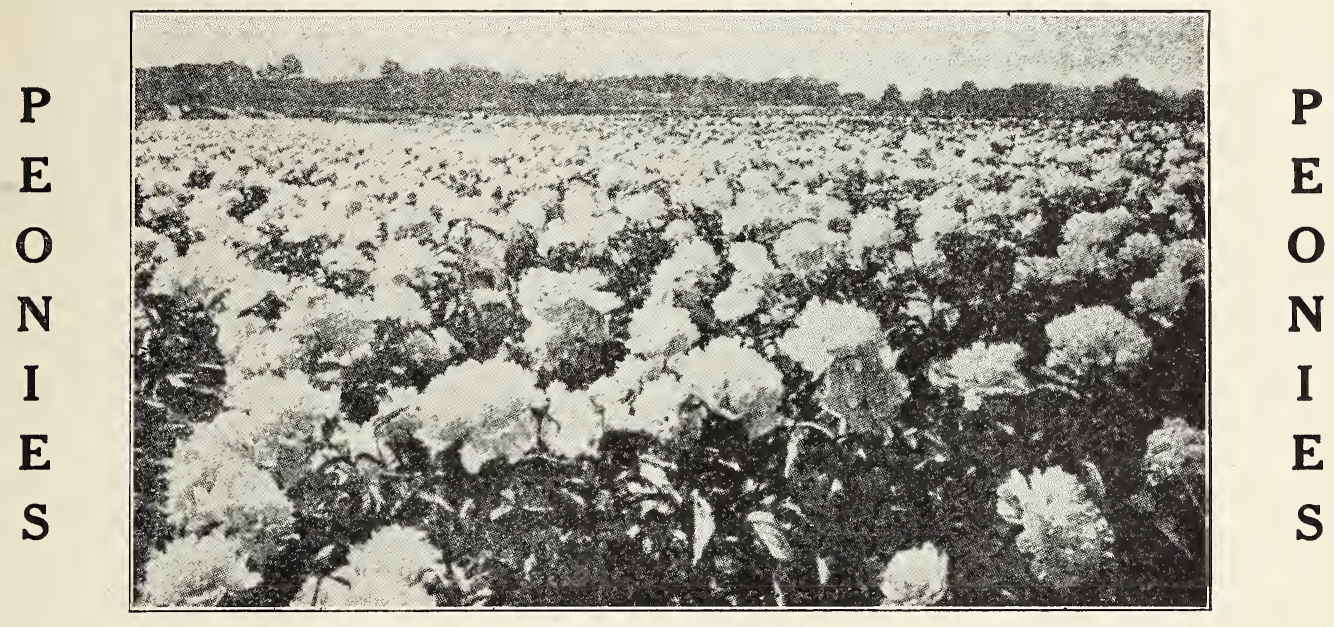

A Wealth of Peonies in Bloom

\section{EXTRA FINE DOUBLE}

Albert Crousse. Very large rosy-white, flecked crimson, tall, erect habit, free bloomer. One of the best cut flower varieties. Each $75 \mathrm{c} ; 10$ for $\$ 7.00$.

Duchesse de Nemoue. An early cup-shaped, freeflowering, fragrant sulphur. Each 50c; 10 for $\$ 4.50$.

Edulis Superba. The famous Memorial Day Peony, it usually can be depended upon to be in flower at that time in this latitude. Color a beautiful light, clear pink with silvery reflex. Large, fragrant flowers. Fach 75c; 10 for $\$ 7.00$.

Felix Crousse. Its large globular fĩowers, solid and compactly built, are of a rich, brilliant, dazzling ruby-eyed, exceptionally fiery, bright and effective. Each $\$ 1.00 ; 10$ for $\$ 9.00$.

Festiva Maxima. The most popular of all the whites, a tall, vigorous grower and free and early bloomer; color pure white, flecked with crimson at center. Each 50c; 10 for $\$ 4.50$.

Karl Rosenfield. Very large, globular, dark crimson flowers, brilliant and striking; a strong but compact grower. Each $\$ 1.25 ; 10$ for $\$ 10.00$.

Offcinalis rubro-plena. Rich, deep crimson; very early and one of the brightest of all dark-colored varieties. Early. Each 60c; 10 for $\$ 5.50$.

Sarah Bernhardt. Blooms are colored in uniform mauve-rose, silver tipped. Flat, compact, fragrant. Late. Each $\$ 1.00 ; 10$ for $\$ 9.00$.

Soulange. The outer petals are delicate lilacwhite tipped toward the center with salmon shadings. The blooms are usually large and compact. Easily one of the best varieties in our collection. Late. Each $\$ 3.00 ; 10$ for $\$ 25.00$.
Therese. Violet-rose changing to lilac-white in the center. Compact rose type which later develops high crown. Plants make a strong growth and produce a multitude of blooms in midseason. Each $\$ 3.00 ; 10$ for $\$ 25.00$.

\section{HARDY PHLOX}

Athis. Light salmon-rose; tallest of all. Each 20c; 10 for $\$ 1.75$.

Bridesmaid. Pure white, with large crimson center. Each 20c; 10 for $\$ 1.75$.

Miss Lingard. The earliest white; immense long heads; blooms from June to September. Each 20c; 10 for $\$ 1.75$.

Mme. P. Langier. Dazzling crimson; extra good. Each 20c; 10 for $\$ 1.75$.

Mrs. Jenkins. Immense panicles of pure white; the best for massing. Each 20c; 10 for $\$ 1.75$.

Pantheon. Rosy salmon; very large. Each 20c; 10 for $\$ 1.75$.

Rheinlander. Unusual shade of salmon-pink, center of claret-red. Both the individual blooms and trusses are very large. Each $20 \mathrm{c} ; 10$ for $\$ 1.75$.

Richard Wallace. White, with violet center. Each 20c; 10 for $\$ 1.75$.

Rosenberg. Bright reddish violet, with blood-red eye; extra large. Each 20c; 10 for $\$ 1.75$.

R. P. Struthers. Brilliant rosy red, with crimson eye. Each 20c; 10 for $\$ 1.75$.

Ryndstrom. Bright rose-pink; very large and fine. Each 20c; 10 for $\$ 1.75$.

\section{DWARF PHLOXES}

Subulata. (Moss Pink.) Low-spreading stems and narrow, moss-like leaves; flowers pinkish purple, with darker center, produced in wonderful profusion in April and May. Makes fine edgings. Each 20 c; 10 for $\$ 1.75$. 
Hardy Garden Pinks. Pronounced spicy fra. grance, beauty and dense, grass foliage. 1 foot. Elsie. Bright red with maroon center. Elizabeth Peters. Single flowers, long summer season, dark red with maroon center. Gertrude. White, variegated with maroon. Jean. (Everblooming.) White with purple center. Each 20c; 10 for $\$ 1.75$.

Platycodon Grandiflorum. (Balloon Flower.) Blooms constantly from July until late in September; flowers large bell-shaped, in numerous loose racemes. Blue or White. Each 15c; 10 for \$1.25.

Plumbago Larpente. (Lead-wort.) An attractive edging plant of evenly rounded and dense growth, about 12 inches high. The tiny leaves of apple green are a rich setting for spikey red buds, and clusters of phlox-like cobalt blue flowers late in summer. Each 20c; 10 for $\$ 1.75$.

Primula Veris. The true English Primrose, with fine clusters of very fragrant spring blossoms in a wide range of colors. Each 20c; 10 for $\$ 1.75$.

Rudbeckia "Golden Glow.", 5 to 7 feet; early summer until frost. Flowers golden-yellow. Purpurea. (Purple Cone-flower.) Large drooping petals colored reddish purple, with a remarkably large cone-shaped center of brown, thickly set with golden tips in spiral lines. 2 to 3 feet. Each 25 c. 10 for $\$ 2.00$.

Salvia-Azurea Grandiflora. (Meadow Sage.) A hardy species of Salvia, very pretty in August and September with its profusion of skyblue flowers. Spreading, 2 to 4 foot plants, with swaying flower wands which arch gracefully clear from the crown. Each 25c; 10 for $\$ 2.0$.

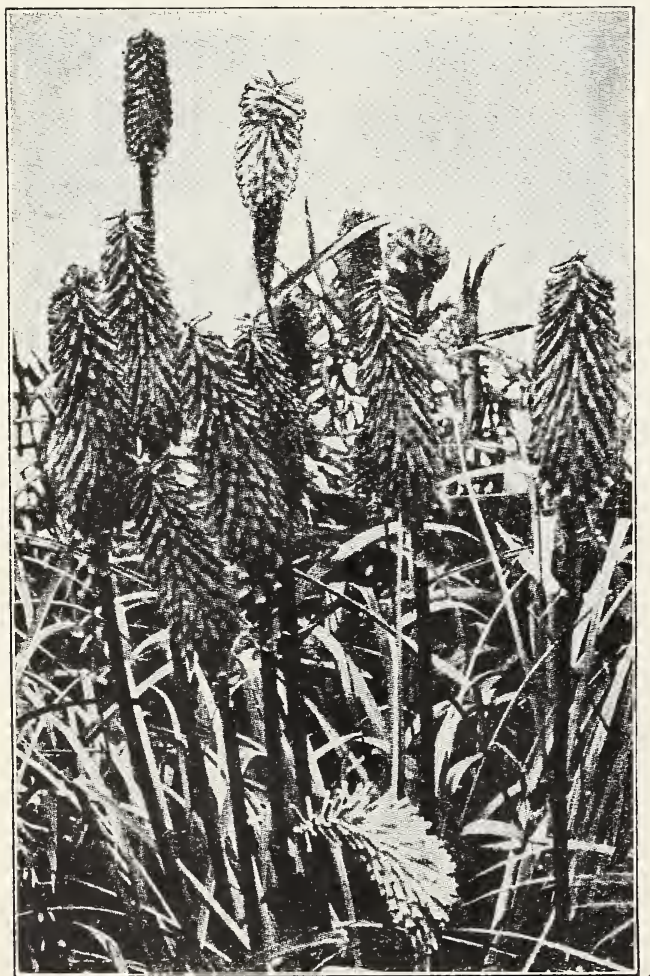

Tritoma Pfitzeri
Stokesia Cyanea. (Stoke's Aster.) One of the most charming hardy plants, freely blooming from July to October. Flowers of Centaurea shape, often measure 4 to 5 inches across. $11 / 2$ to 2 feet. Blue or White. Each 20c; 10 for $\$ 1.75$.

Tradescantia Virginica Alba. (Spiderwort.) Plants about 2 feet tall, with richly green foliage and clustered white blossoms an inch wide; in bloom all summer. Each 20c; 10 for $\$ 1.75$.

Veronica Longifolia Subsessilis. (Speedwell.) A 3 foot border plant with attractive foliage of distinct character, a roughened bronze-green. Flowers are borne abundantly during July and August, in long, compact spikes. Deep blue. Each 25c; 10 for $\$ 1.75$.

Tritoma Pfitzeri. (Red Hot Poker.) Rush-like foliage supports smooth thick flower stalks a yard long, with a single fiery cone at the top. Brilliant scarlet, the opened lower petals trimmed with orange. July-September. Must be carefully protected or else carried dormant in dry sand during winter. Each 25c; 10 for $\$ 2.00$.

Yucca Filamentosa. (Adams Needle or Spanish Bayonet.) A stately foliage and flowering plant, always conspicuous. The broad, sword-like foliage is evergreen; supporting a showy display of pendant creamy-white bells. Each 30c; 10 for $\$ 2.50$.

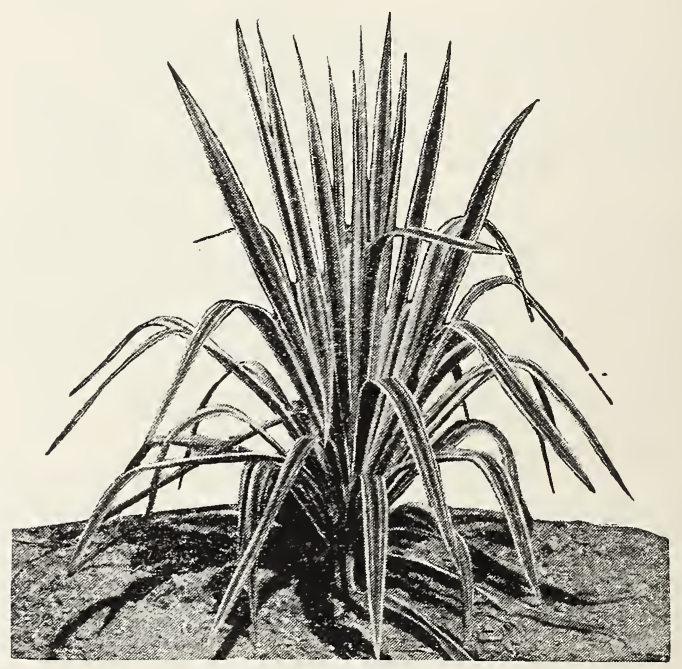

Variegated Leaf Yucca

Hacker's Veriegated Leaf Yucca. Derived from Yucca Filamentosa, and conforming closely thereto in form, habit, and panicled bloom-which first occurs at three years on a rigid 3 to 4 -foot stalk. The surrounding bayonet-like leaves are dark, bronze-green at center, breaking up with minor stripes to a broad outer edge of yollow. This foliage is permanent, assuming a contrastive purple tinge against winter's snow. A very striking punctuation plant among solid colors for summer show, and ranking with evergreens for winter usefulness; perfectly hardy in extremes of either cold or heat. Strong 1 year plants. Each 75c; 10 for $\$ 6.50$. 


\section{SUMMER FLOWERING BULBS \\ AMARYLLIS}

Valuable alike for house, conservatory or garden. For pot culture they should be well drained and potted in soil composed of leaf mold and light loam, although they grow well in any rich soil.

Formossissima. (Jacobean Lily.) Crimson velvet, flowering early in summer. Each 75c; 10 for $\$ 6.00$.

Johnsonii. Brilliant red flowers 5 inches in diameter, with a distinct white stripe in the center of each petal; very fragrant. Each 75c; 10 for $\$ 6.00$.

\section{CALADIUMS}

Esculentum. ("Elephant's Ear.") For obtaining tropical efiects in lawn and garden planting. Should have plenty of water and good rich soil. Stands 6 to 7 feet high, with bright green leaves three to four feet long and two and one-half feet wide. Each 35c; 10 for $\$ 3.00$.

Fancy Leaved. A class of beautiful variegate $\dot{\alpha}$ foliage plants, excellent for window boxes, vases or single pot plants, succeeding equally well in a somewhat shady situation out of doors. They delight in a shady and moist place. Each 40c; 10 for $\$ 3.50$.

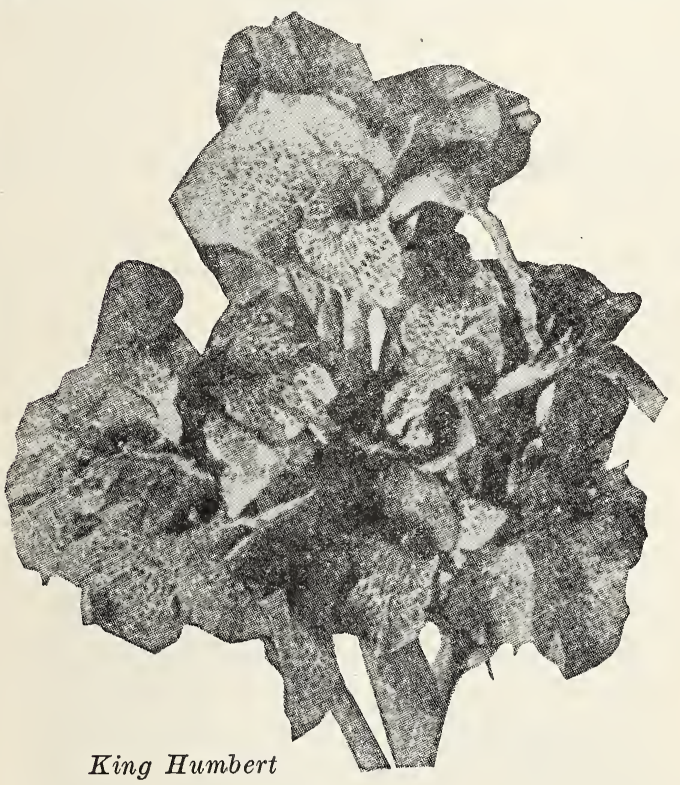

CANNAS

THE GRANDEST OF ALL BEDDING PLANTS

Crimson Bedder. 5 feet. Crimson flowers. Green foliage. Each 25c; 10 for $\$ 2.25$.

Hungaria, 5 feet. Pure rose pink. Each 30c; 10 for $\$ 2.50$.

King Humbert. 5 feet. Rich orange and bright red; bronze foliage. Each 25c; 10 for $\$ 2.25$.

Richard Wallace. 6 feet. Pure yellow, green foliage Each 25c: 10 for $\$ 2.25$.

Mont Plarc 11 feet Pure white flowers, green folinge. Each 25c; 10 for $\$ 2.25$.

Mad. Crozy. $3 \frac{1 / 2}{2}$ feet. Vermilion with gold border. Green foliage. Each 25c; 10 for \$2.25.

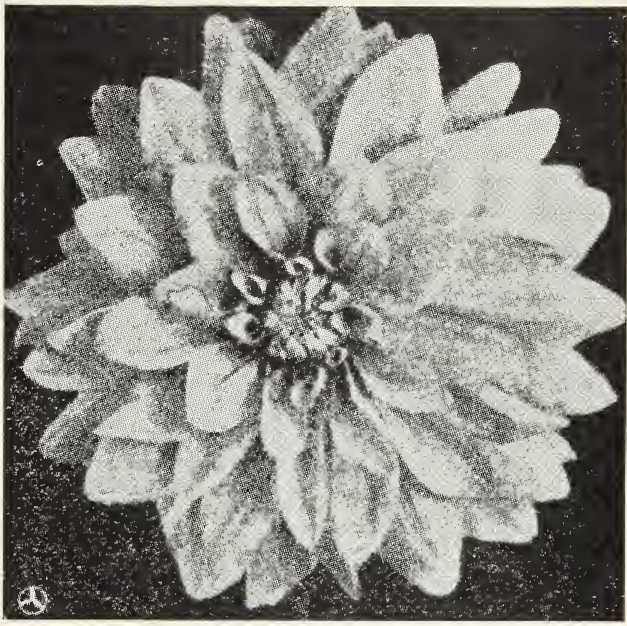

Decorative Dahlia

\section{DECORATIVE DAHLIAS}

Double Dahlias. Choicest show dahlias, finest assortment. Choice of colors; red, yellow, pink, white and variegated. Roots with several eyes. Each 25c; 10 for $\$ 2.00$.

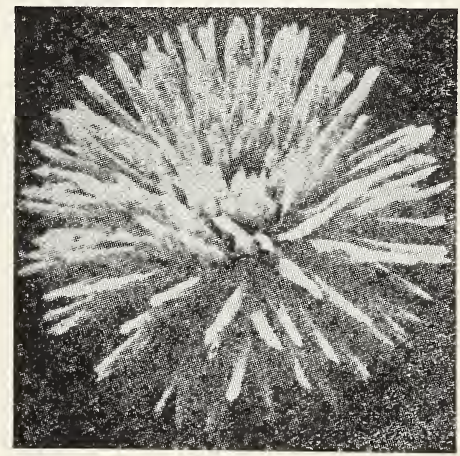

Cactus Dahlia

\section{CACTUS DAHLIAS}

Characterized by long, narrow, pointed tubular and twisted petals of graded lengths, giving the layered flowers a very striking and attractive appearance. Choice of colors; red, pink, white, yellow and variegated. Each $30 \mathrm{c} ; 10$ for $\$ 2.50$.

\section{GLADIOLUS}

Gladiolus. The gladiolus is one of our most beautiful summer flowering bulbs. It has brilliant spikes of flowers two feet or more in height, often several from one bulb, of most deisrable colors. Each 15c; 10 for $\$ 1.25 ; 100$ for $\$ 8.00$.

\section{TUBEROSE}

Tuberose. Double Excelsior Pearl. This is a beautiful waxlike, sweet-scented, double, white flower, growing on more flowers. Each 15c; 10 for $\$ 1.25$. 


\section{PLANT DEPARTMENT}

\section{ABUTILON}

Abutilon (Flowering Maple.) Popular for pot plants, for summer bedding, vases and baskets. Flowers perfect, bell shaped, various colors; masses all summer. Each 25c; 10 for \$2.25.

Souvenir de Bonn. Variegated leaf. Deep green maple-shaped leaves, irregularly bordered with creamy white. Very free flowering with bright orange flowers, veined crimson. Each 30c; 10 for $\$ 2.25$.

\section{ASPARAGUS}

Plumosus Nanus. One of the handsomest of our foliage plants for pot culture, beautiful the year round, and there is no more decorative plant in the entire list. Easily grown even in a north window. Leaves are bright, finest silken mesh. 25c, $50 \mathrm{c}, 75 \mathrm{c}$ and $\$ 1.00$.

\section{BEGONIAS}

\section{HOUSE AND BEDDING BEGONIAS}

Rex. Of these very desirable pot plants we grow about a dozen of the very choicest varieties. Each 35c; 10 for $\$ 3.00$.

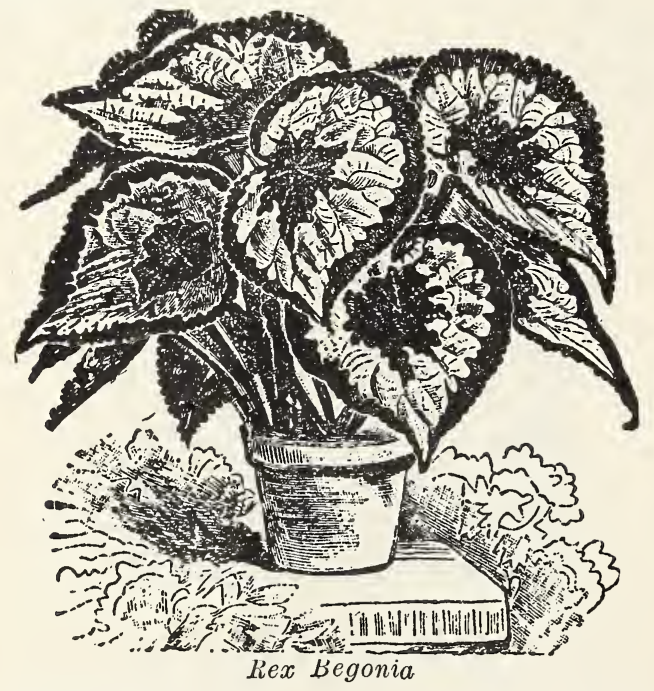

Semperflorens Rubra. This fine variety is a constant bloomer. Heavy waxy green leaves. Flowers rosy scarlet. Each 25c; 10 for $\$ 2.00$.

Semperflorens Rosea. Flowers of pink, blush and brilliant red; foliage sometimes margined with bronze purple. Each 25c; 10 for $\$ 2.00$.

Thurstoni. Remarkable fine foliage, the under side of the leaves being rich purplish red, with prominent veinings. Upper side bronze green, shaded crimson and olive and a metallic luster ove: all. Flowers rosy, white, in clusters. Each 25c; 10 for $\$ 2.25$.

\section{CARNATION}

Victory. Bright red. Each 25c.

White Wonder. Pure white. Each 25c

Pink Enchantress. Blush pink. Each 25c.

Harlowarden. Dazzling crimson. Each 25c.

Any of the above 10 for $\$ 2.00$.

\section{COLEUS}

Coleus. Very fine bedding or pot plants of rapid growth and easy culture; 24 varieties, including all choice shades of colors. Each 25c; 10 for $\$ 2.00$.

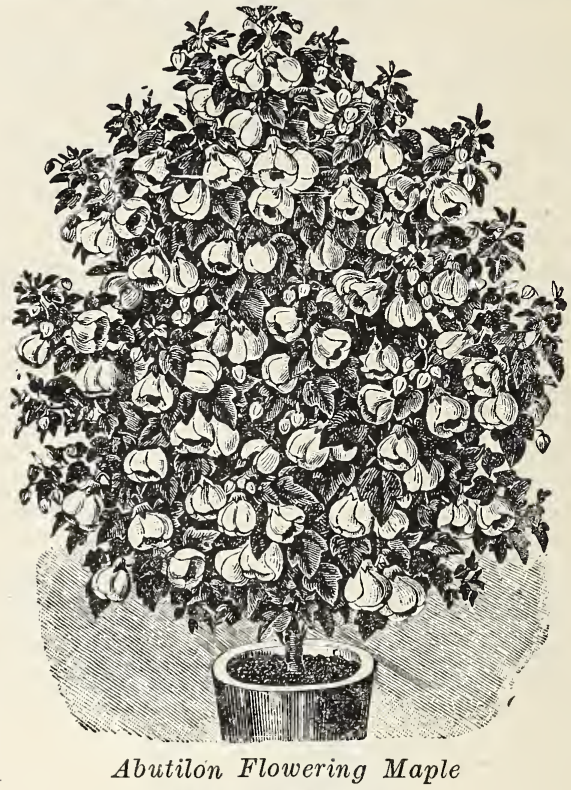

DRACENA

Indivisa. This is the best known sort; with graceful, slender, arching numerous green leaves. For many years the leading variety of center-plant for vase and window

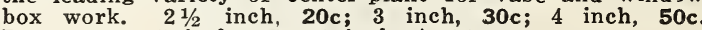
By express, 5 inch, $75 \mathrm{c} ; 6$ inch, $\$ 1.00$.

Terminalis. Leaves rather long and pointed, deep bronze, coloring richly to crimson, marked with pink and green and occasionally streaked with white. Although like all self-coloring foliage, this variety has its dull aspects, sunshine, warmth and the evolutions of its normal seasons produce a wonderful brilliancy. 3 inch pots, $75 \mathrm{c}$ each.

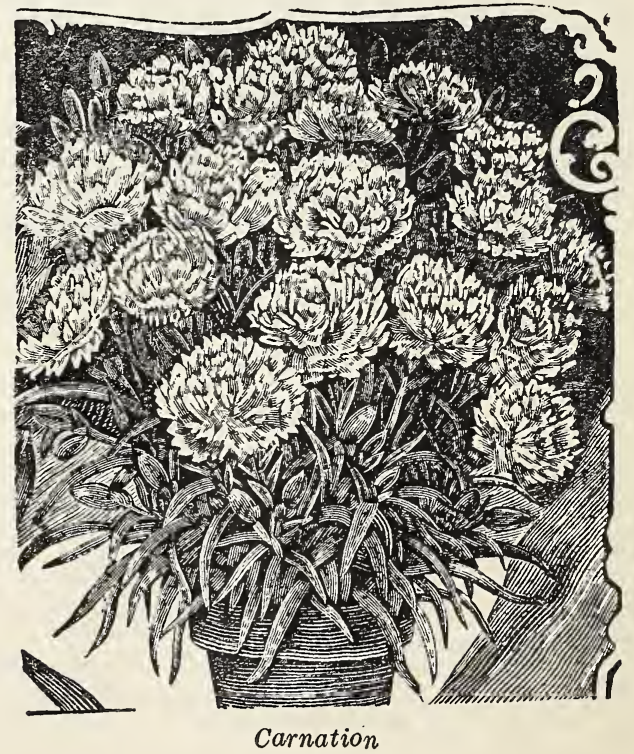




\section{FERNS}

Boston Fern. This is one of the old stand-bys, and still one of the best. Its long, graceful drooping fronds often attain a length of five or six feet in a single year. Each 20c; 10 for $\$ 1.75 ; 2$ year old strong plants $\$ 1.00$ each.

\section{FUCHSIAS}

Phenomenal. Scarlet and purple; has double flowers of immense size; good grower. Each 25c; 10 for $\$ 2.00$.

Mrs. E. G. Hill. Scarlet and white, double flower; same type as Phenomenal. Each $25 \mathrm{c} ; 10$ for $\$ 2.00$.

Speciosa. (The True Winter Blooming Fuchsia.) This lovely Fuchsia blooms with greatest profusion during winter, is scarcely ever without flowers from September

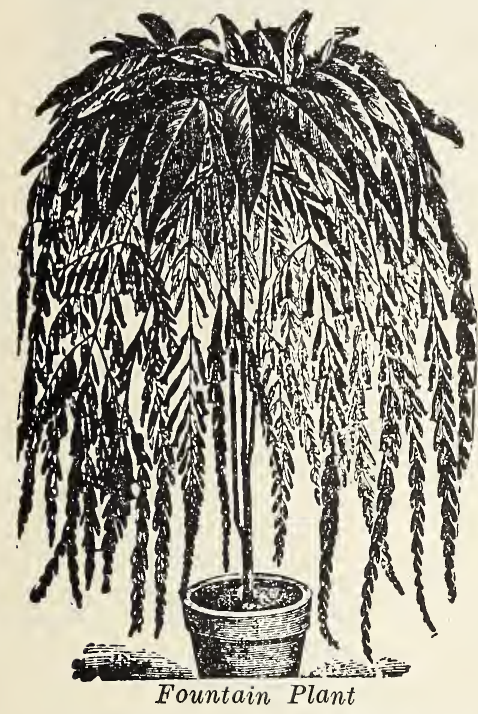

till June; the flow. ers are large and of the most graceful form; color, $\mathrm{ri} \mathrm{c} \mathrm{h}$ carmine and rose: most charming window plant, remarkable for its glossy $\mathrm{g}$ r e e $\mathrm{n}$ leaves and constant porfusion of exquisitely beautiful flowers. Each 25 c; 10 for $\$ 2.00$.

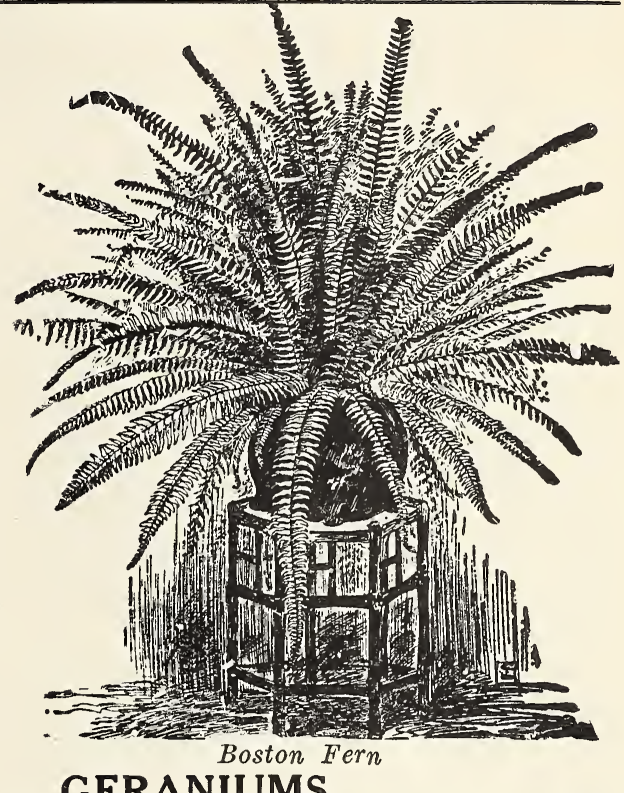

Queen of Crimson. S. A. Nutt. One of the best dark crimson sorts. Large, bold, abundant flowers on large, splendid trusses. Each 20c; 10 for $\$ 1.75$.

Madame Barney. Large, semi-double, pure pink, of a lovely shade. Dwarf and branching; free flowering. Each 20c; 10 for $\$ 1.75$.

La Favorite. Pure white, elegant flowers of surpassing beauty. Each 20c; 10 for $\$ 1.75$.

\section{HELIOTROPE}

Florence Nightingale. One of the most fragrant and the best flowering lavender. Each 20c; 10 for $\$ 1.50$.

No plant makes more handsome specimens in tubs for verandas or in the yard. The flowers are usually double when mature.

Rosea. Double pink flowered. Each 25c; 10 for $\$ 2.00$.

Lillian. Flower in pure white. Each 25c; 10 for $\$ 2.00$.

\section{PALMS}

Kentia Balmoreana. Gracefully arching stems of steely strength despite their slenderness. Each crowned with its fan. like canopy of richest green. The breaking forth of each new leaf is a ceremony; its slow advance to an equality with its fellows, a triumphant progress. Leaf by leaf, our pride and interest keep pace with its maturing beauty. Each 30c; 10 for $\$ 2.50$. Two feet, $\$ 3.50 ; 3$ to 4 feet, each $\$ 10.00$.

\section{PELARGONIUMS}

\section{IADY WASHINGTON GERANIUMS}

Easter Greeting. Flowers large red, each petal marked with a large blotch. Each 30c; 10 for $\$ 2.50$.

Kingston Beauty. Silvery white crimpled. Each 30c; 10 for $\$ 2.50$.

\section{PETUNIAS}

Petunia Double. Pink, red and white. Each 25c; 10 for $\$ 2.00$.

\section{THRYSACANTHUS RUTILANS}

\section{(Fountain Plant)}

A greenhouse plant of easy growth and when in bloom a graceful specimen for table decoration. Its tubular shaped carmine flowers are borne on long drooping thread-like branches. 12 to 16 inches in length. 25c each; 10 for $\$ 2.00$.

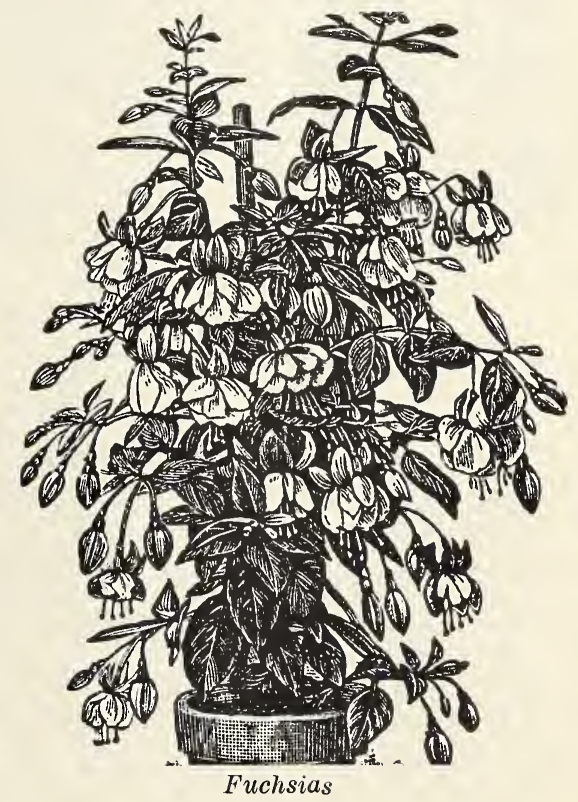




\section{FRUIT TREE DEPARTMENT}

\section{APPLES \\ SUMMER APPLES}

Early Harvest. Fruit medium size, greenish yellow, tender and juicy. July. 5 to 7 feet. Each $80 \mathrm{c}$; 10 for $\$ 7.00$.

Golden sweet. Large, pale yellow, sweet, productive, valuable for market; early. 5 to 7 feet. Each 80c; 10 for $\$ 7.00$.

Red Astrachan. Tree hardy and regular bearer, a very vigorous grower; fruit large, roundish, nearly covered with deep crimson overspread with a thick bloom; juicy, rich and beautiful. This fruit commands the best price of all the summer varieties. July and August. 5 to 7 feet. Each $80 \mathrm{c} ; 10$ for $\$ 7.00$.

Yellow Transparent. (Summer.) One of the best extra early varieties. Excellent for both culinary use and dessert. Fruit large, crisp, tender, juicy, subacid. Skin yellowish-white. Tree medium size, vigorous and hardy. Ripens July and August. 5 to 7 feet. Each $80 \mathrm{c} ; 10$ for $\$ 7.00$.

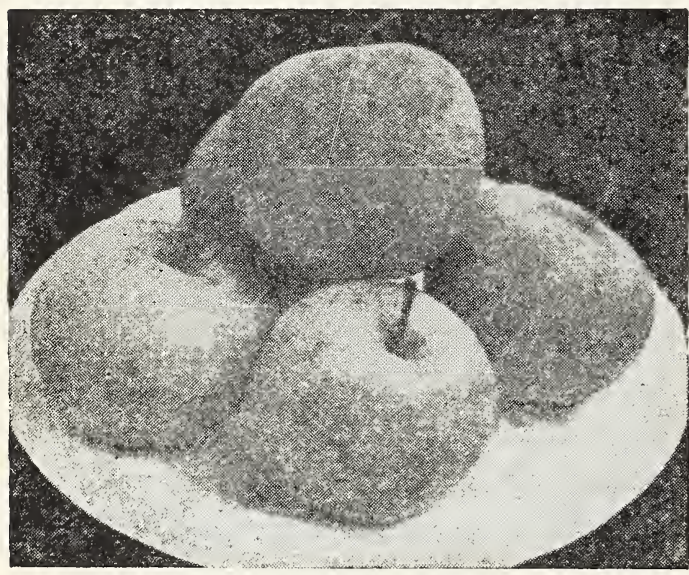

Yellow Transparent

\section{AUTUMN APPLES}

Autumn Strawberry. Good size and color, fair quality for table and market. Ripens in September. 5 to 7 feet. Each $80 \mathrm{c} ; 10$ for $\$ 7.00$.

Duchess of Oldenburg. A large, beautiful Russian apple; roundish; streaked red and yellow; tender, juicy and pleasant. 5 to 7 feet. Each 80c; 10 for $\$ 7.00$.

Maiden Blush. Good size, fine flavored, beautifully blushed, good bearer, a fine apple for home and market. September. 5 to 7 feet. Each 80c; 10 for $\$ 7.00$.

Gravenstein. Orange yellow with stripes of light and dark red; tender, juicy, aromatic, subacid. Good size and attractive appearance. Ripens late in September, lasts to early November. 5 to 7 feet. Each 80c; 10 for $\$ 7.00$.

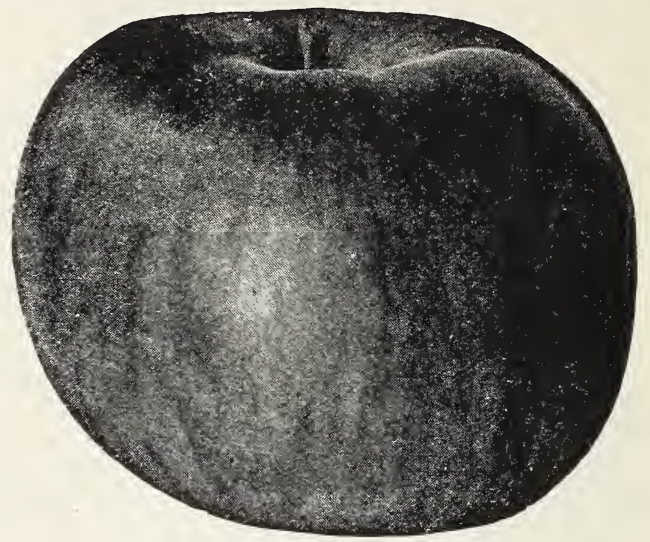

Red Astrachan

Ohio Nonpareil. Fruit is enormous in size, one half of each specimen bright red. 5 to 7 feet. Each 80c; 10 for $\$ 7.00$.

Fall Pippin. Very large, yellow, tender, juicy and rich. Fine in all localities; tree vigorous. September and October, 5 to 7 feet. Each 80c; 10 for $\$ 7.00$.

Alexander. Large, deep red or crimson; flesh yellowish white, crisp, tender, with pleasant flavor. Tree very hardy. October. 5 to 7 feet. Each $80 \mathrm{c} ; 10$ for $\$ 7.00$.

\section{WINTER APPLES}

Baldwin. A great market apple, very productive of fair, handsome fruit. No variety yields larger crops or bears shipment better, or is more attractive in color and size and shape, than the Baldwin. It is esteemed as an eating apple, and for cooking. 5 to 7 feet. Fach $80 \mathrm{c}$; 10 for $\$ 7.00$.

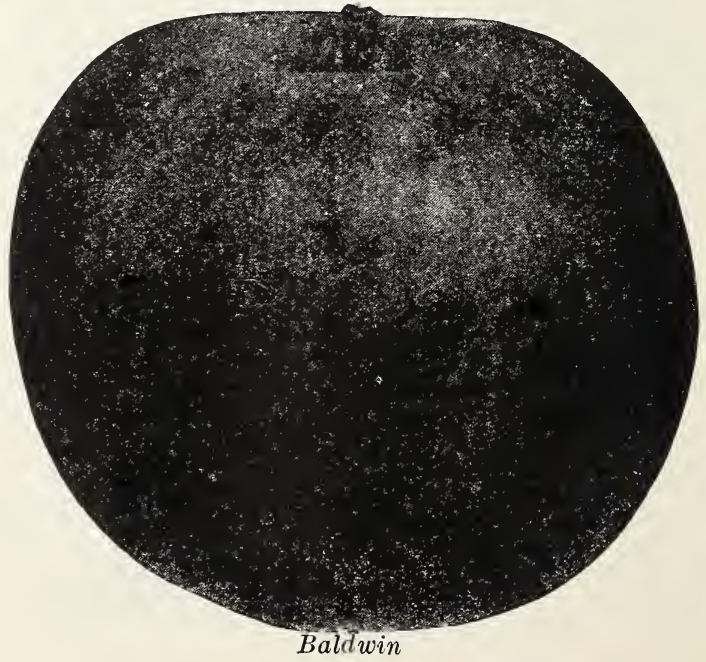


Golden Russet. Medium size, full russet with a tinge of red; flesh greenish yellow, crisp, juicy and high flavored. A good keeper. 5 to 7 feet. Each 80c; 10 for $\$ 7.00$.

Greening. Extremely hardy and vigorous grower. Fruit large, greenish yellow when ripe. Good quality and a long keeper. Especially recommended for Northern states. 5 to 7 feet. Each $80 \mathrm{c} ; 10$ for $\$ 7.00$.

Grimes Golden. Large, golden yellow. Favorite sort because of extra choice quality; 5 to 7 feet. Each 80c; 10 for $\$ 7.00$.

King. Very large and fine, red striped, subacid. 5 to 7 feet. Each 80c; 10 for $\$ 7.00$.

Northern Spy. A hardy, red winter apple, a vigorous and healthy grower, forming an upright tree of large size quicker than most varieties. It has no superior for beauty and quality. When at its best it is of large size and an abundant bearer, and a good keeper. 5 to 7 feet. Each $80 \mathrm{c}$; 10 for $\$ 7.00$.

Wealthy. Large, red, showy; subacid and productive. Most popular of all. 5 to 7 feet. Each $80 \mathrm{c} ; 10$ for $\$ 7.00$.

Delicious. A remarkable variety rapidly taking firsi rank both for commercial and home orchards. Fruit large, nearly covered with brilliant dark red, flesh, fine grained, crisp and mel+ing, juicy, with a delightful aroma: of very highest quality. A splendid shipper, bearing annually. Each 80c; 10 for $\$ 7.00$.

\section{PEARS}

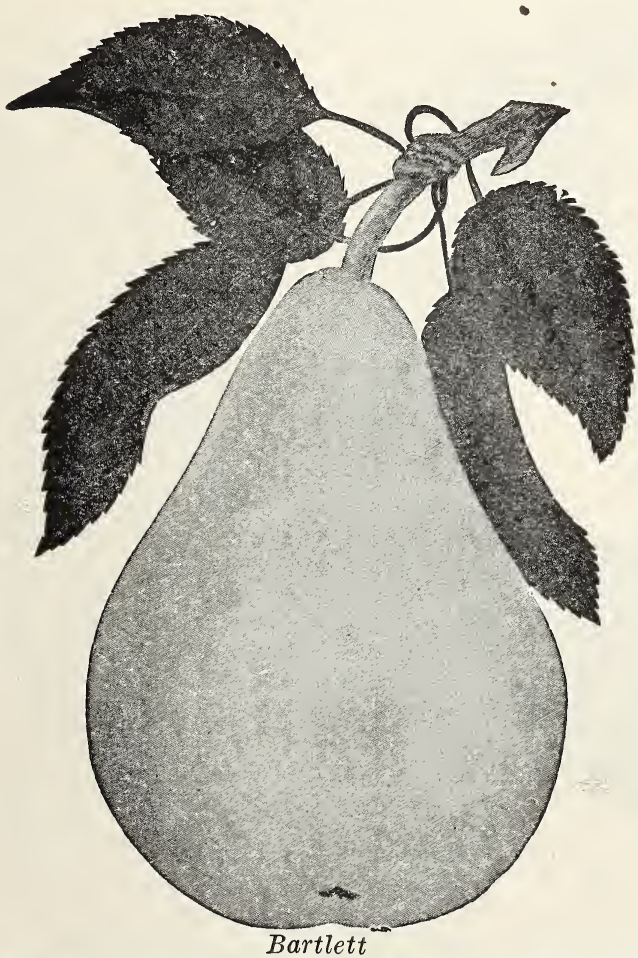

Bartlett. Large, yellow, flesh white, exceedingly fine grained, and buttery. 5 to 7 feet. Each $\$ 1.10 ; 10$ for $\$ 10.00$.

Flemish Beauty. Standard dwarf. A large, beautiful, melting, sweet pear. Tree very hardy, vigorous and fruitful. Flesh is tender, juicy and highly flavored. Season September. 5 to 7 feet. Each $\$ 1.00 ; 10$ for $\$ 8.50$.

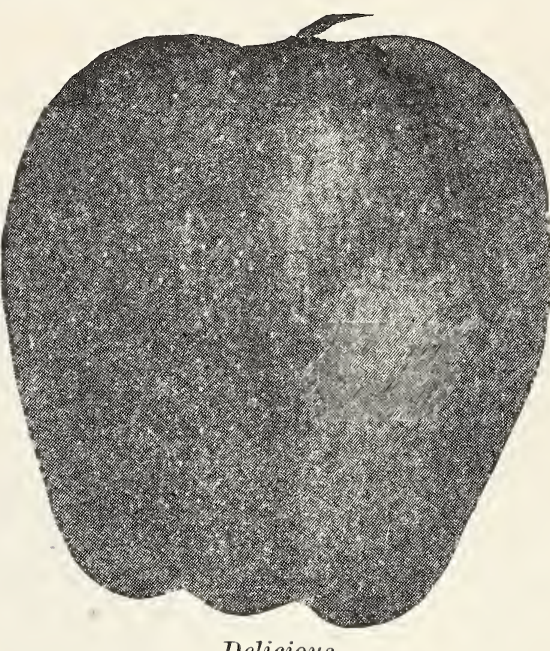

Delicious

Early Harvest. The best early variety. 5 to 7 feet. Each $\$ 1.00 ; 10$ for $\$ 8.50$.

Clapp's Favorite. 'Tree a vigorous, upright, spreading grower, very hardy and productive. Fruit very large, of uniform size, pale yellow, flesh fine grained, juicy, but. tery, melting, sweet and rich. 5 to 7 feet. Each \$1.00; 10 for $\$ 8.50$.

Duchess Pear. (Duchess d'Angouleme.) A large, handsome pear, buttery and melting, with sprightly vinous flavor; keep into mid-winter. Tree a vigorous grower and a good bearer. It keeps until January with special care. It is healthful in shape and color. Season Octobex and November. 5 to 7 feet. Each $\$ 1.00 ; 10$ for $\$ 8.50$.

Seckel. Small, but of excellent quality; very hardy. Ripen in September. 5 to 7 feet. Each $\$ 1.00 ; 10$ for $\$ 8.50$.

Keiffer. Fruit large to very large, skin yellow, with bright vermilion cheek; flesh brittle, very juicy, quality good. 5 to 7 feet. Each $\$ 1.00 ; 10$ for $\$ 8.50$.

Kaiser. This is one of the best Autumn pears. Enormous bearer, with very large oblong shape fruit, color red cheek on the south side and yellow on the north side, exceedingly juicy; one of the richest and highest flavored pears; ripens in September. Each $\$ 1.10 ; 10$ for $\$ 10.00$

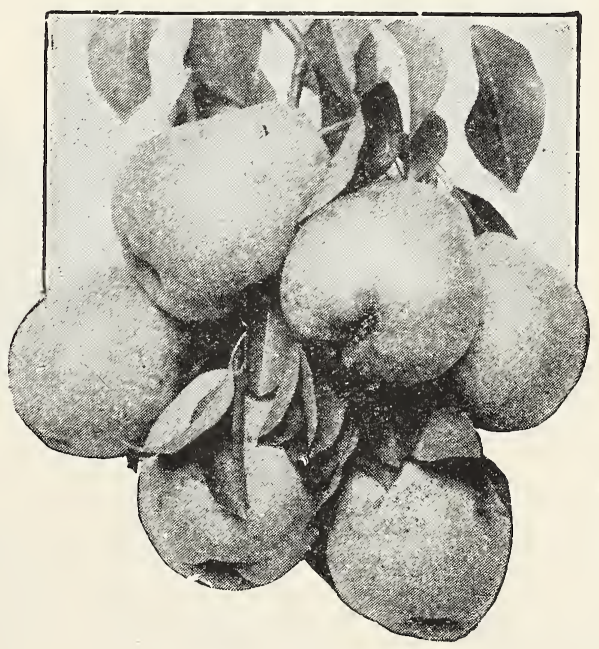

Flemish Beauty 


\section{PLUMS}

\section{JAPAN PLUMS}

Abundance. Beautiful lemon yellow nearly overspread with bright cherry; oblong; flesh orange yellow, melting rich and highly perfumed. Abundant and unusual bearer. 5 to 7 feet. Each 80c; 10 for $\$ 7.50$.

Burbank. Considered by some to be the best of all the European sorts. Color clear cherry red with thin lilac bloom. Flesh deep yellow, very sweet and agreeable. 5 to 7 feet. Each 80c; 10 for $\$ 7.50$.

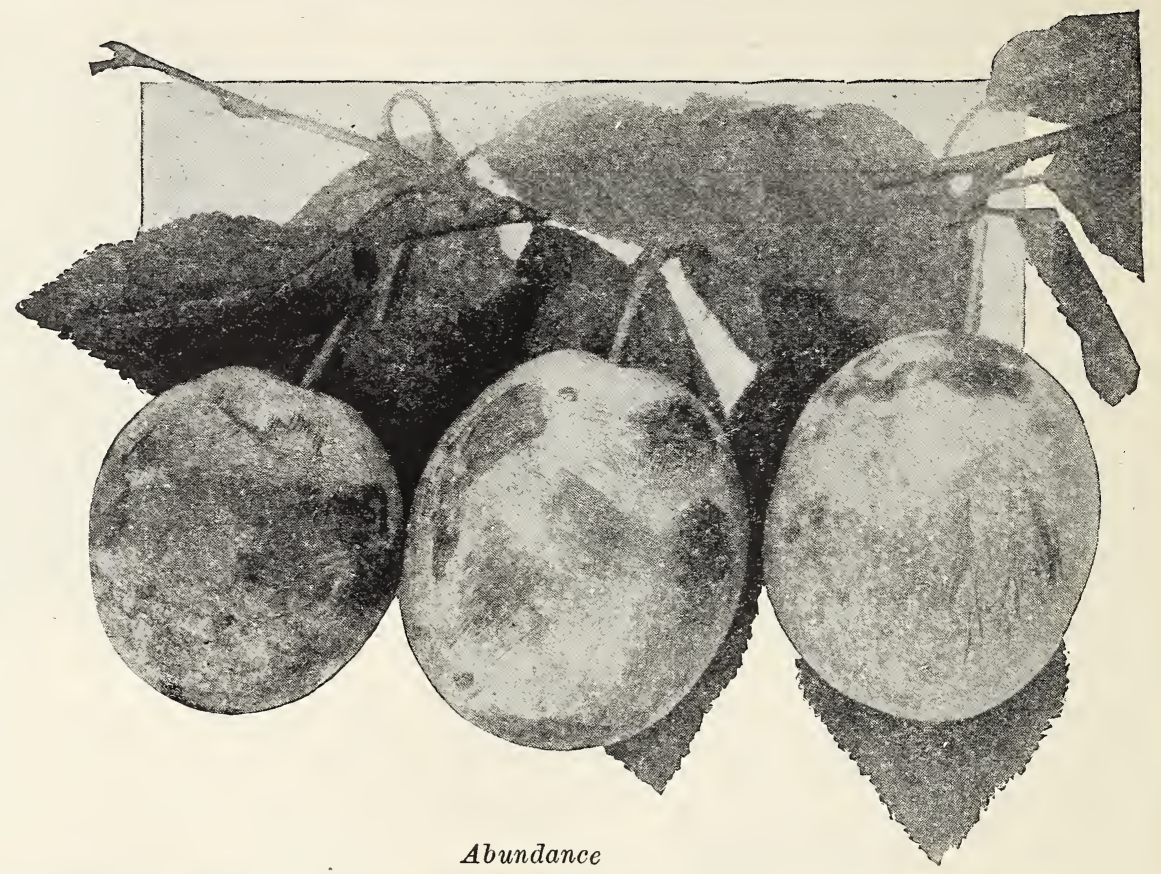

\section{EUROPEAN PLUMS}

Bradshaw. Very large, dark violet red. Flesh yellow, juicy, good quality. August. 5 to 7 feet. Each 80c; 10 for $\$ 7.50$.

Felemberg Prune. A fine prune, oval, purple, flesh juicy and delicious; part from the stone; fine for drying; tree very productive. Early September, 5 to 7 feet. Each $80 c ; 10$ for $\$ 7.50$.

German Prune. A valuable plum of fair quality for dessert, but most esteemed for drying and preserving. Large, long-oval; purple with a thick blue bloom; flesh firm, sweet and pleasant, separating from the stone. Moderate to vigorous in growth. September. 5 to 7 feet. Each $\$ 1.00 ; 10$ for $\$ 9.00$.

Lombard. A strong growing tree and exceedingly productive. It is a handsome reddish plum; flesh yellow, juicy and pleasant. An excellent variety and should be planted in all gardens and orchards. 5 to 7 feet. Each 80c; 10 for $\$ 7.50$.

Yellow Egg. Very large, egg shape. Color creamy yellow. Flesh yellow and of fine quality. 5 to 7 feet. Each 80c; 10 for $\$ 7.50$.

\section{SWEET CHERRIES}

Red June. The great early market variety. Medium to large, deep red, with beautiful bloom. Flesh lemon yellow, firm and of delightîul quality. Ripens early August. 5 to 7 feet. Each $\$ 1.10$; 10 for $\$ 10.00$.

Bing. Very large size, almost black in color when ripe; of fine quality, very productive, a good shipper, 5 to 7 feet. Each $\$ 1.10 ; 10$ for $\$ 10.00$.

Black Tartarian. An old and popular variety, large, purplish black, juicy, rich. excellent, early. 5 to 7 feet. Each \$1.10; 10 for $\$ 10.00$.

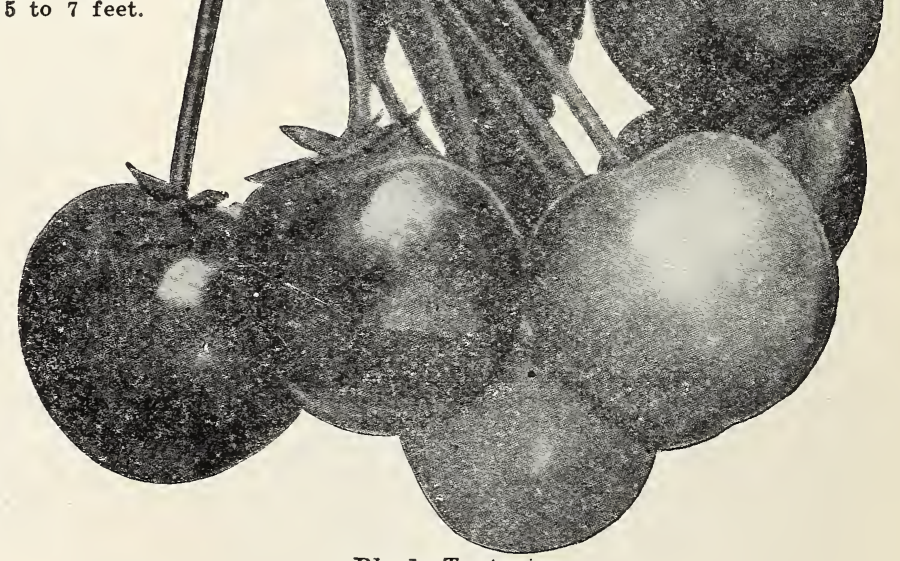

Black Tartarian

Lambert. One of the largest, heart shaped, dark purplish red, flesh firm and solid, rich and juicy; seed small; ripens in July. Very hardy, an enormous bearer. 5 to 7 feet. Each $\$ 1.10 ; 10$ for $\$ 10.00$.

Napoleon Bigarreau. (Royal Ann.) Skin pale yellow, richly dotted with deep red. June. 5 to 7 feet. Each $\$ 1.10 ; 10$ for $\$ 10.00$. 


\section{SOUR CHERRIES}

Early Richmond. Medium size, dark red, juicy, acid flavor. Unsurpassed for cooking. The standard early variety, 4 to 5 feet. Each $\$ 1.00 ; 10$ for $\$ 9.00$.

English Morello. Fruit large, very dark red, nearly black; tender, juicy, acid, rich, of good quality. Owing to its rich red color looks much better when canned than the Early Richmond. Tree dwarf, slender and spreading, bears young. Ripens July. 4 to 5 feet. Each $\$ 1.00 ; 10$ for $\$ 9.00$.

Large Montmorency. Large red acid cherry; is larger than Early Richmond and about ten days later. A superior sort for home use. 4 to 5 feet. Each $\$ 1.00 ; 10$ for $\$ 9.00$.

Late Duke. Large, light red, late and excellent. It ripens when most other cherries are gone and always brings a good price in the market. Ripens end of July. 4 to 5 feet. Each $\$ 1.00 ; 10$ for $\$ 9.00$.

May Duke. Large, red; juicy and rich; an old, excellent variety; vigorous, productive. June 15 . Each \$1.00; 10 for $\$ 9.00$.

\section{QUINCES}

Apple-Shaped. The best of the older varieties, still more extensively cultivated than any other. Its large, roundish fruit ripens in October. 4 to 5 feet. Each $\$ 1.00 ; 10$ for $\$ 9.00$.

Champion. Fruit large, oval, rich and aromatic; fine quality; long keeper. 4 to 5 feet. Each $\$ 1.00 ; 10$ for $\$ 9.00$.

\section{PEACHES}

Alexander Early. Medium size, almost red. Flesh white, tender, juicy. Middle of July. 5 to 6 feet. Each 50c; 10 for $\$ 4.00$.

Beer's. Large size, light orange yellow, with red cheek; flesh yellow, juicy, rich and free from the stone. October. Excellent late sort. 5 to 6 feet. Each 50 c; 10 for $\$ 4.00$.

Champion. Fruit large, beautiful in appearance; flavor delicious; skin creamy white, with red cheek; freestone. Trees hardy and prolific. One of the best varities for home use. 5 to 6 feet. Each $50 \mathrm{c} ; 10$ for $\$ 4.00$.

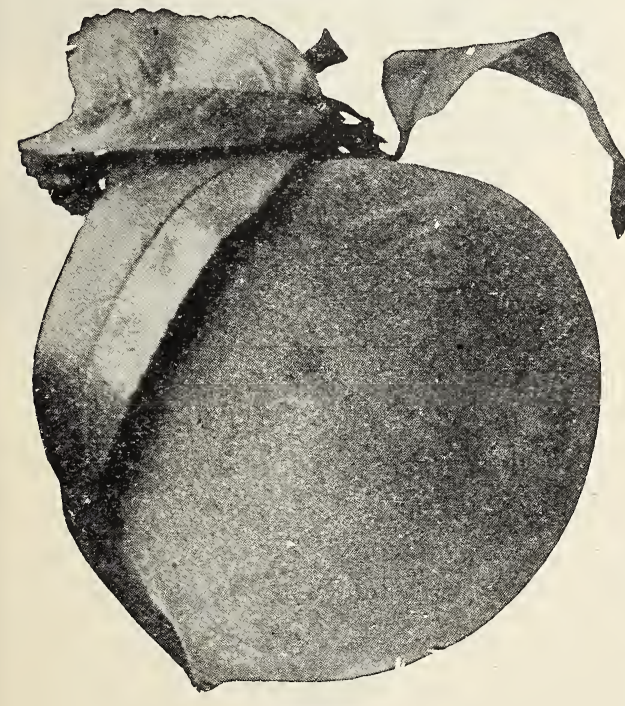

Elberta

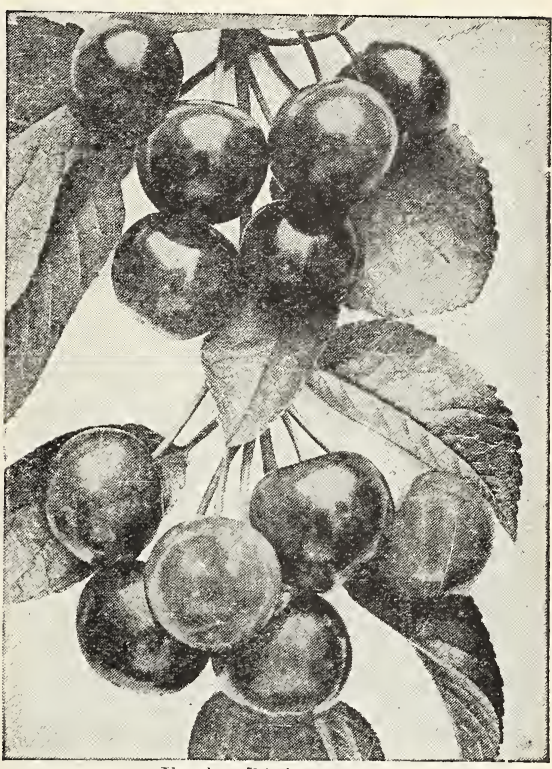

Early Richmond

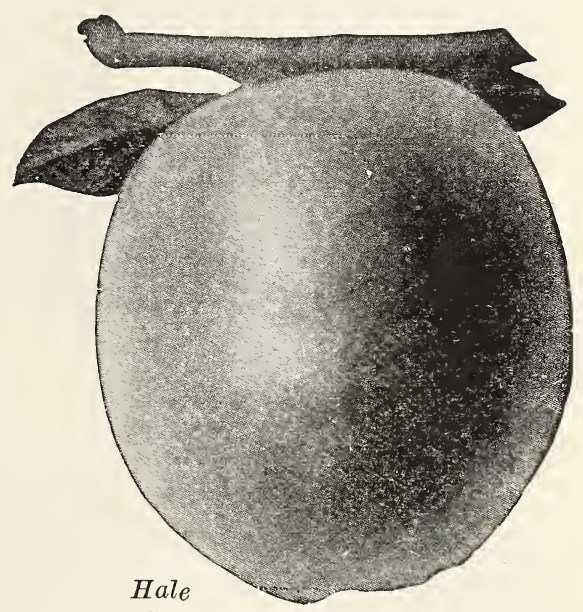

J. H. Hale. Probably no new peach has ever been introduced claiming to be much superior in all ways. It averages one-third to one-half larger than Elberta, ripens about five days earlier and is much superior in flavor. Color a beautiful golden yellow, with deep ermine blush. It has been tested and largely planted in many sections of the country. Each $50 \mathrm{c} ; 10$ for $\$ 4.00$.

Crawford's Late. Large, yellow with a red cheek; flesh deep yellow, juicy and melting. 5 to 6 feet. Each 50c; 10 for $\$ 4.00$.

Crawford's Early. Highly esteemed for market. Fruit very large, oblong, yellow with showy red cheek. Flesh yellow, juicy and sweet. A good bearer. August. 5 to 6 feet. Each 50 c 10 for $\$ 4.00$.

Elberta. The most popular peach in the market. Large, yellow and red, handsome. Flesh yellow, juicy and sweet. Ripens after Early Crawford. 5 to 6 feet. Each 50c; 10 for $\$ 4.00$.

Fitzgerald. It is one of the hardiest peaches, both in bloom and tree; very prolific; large size. Sept. 1st. 5 to 6 feet. Each 50c; 10 for $\$ 4.00$. 
Heath Cling. (Clingstone.) Large and round; white with black spots, juicy and fine quality. Best peach for pickles. October. 5 to 6 feet. Each 50c; 10 for $\$ 4.00$.

Niagara. Fruit large, oval, yellow with brilliant red cheek. The stone parts freely from the flesh. Flavor, rich and delicious. Ripens just before Elberta, 5 to 6 feet. Each 50c; 10 for $\$ 4.00$.

Yellow St. John. Large, yellow with deep red cheek; flesh yellow, sweet, juicy, very good; bears quite young. Ripens before Early Crawford. 5 to 6 feet. Each 50c; 10 for $\$ 4.00$.

\section{APRICOTS}

Alexander. Very hardy and immense bearer; fruit large; yellow, flecked with red; very beautiful, sweet and delicious. July. 5 to 6 feet. Each $80 \mathrm{c} ; 10$ for $\$ 7.50$.

\section{NUT TREES}

American Sweet Chestnut. By far the most popular variety of chestnut. 5 to 6 feet. Each $\$ 1.00 ; 10$ for $\$ 9.00$.

European or English Walnut. A fine, lofty growing tree, with handsome, spreading head; produces large crops of thin-shelled, delicious nuts which are always in demand at good prices. The nut needs no description; everyone is glad to get some to eat. The trees we offer are 5 to 6 feet. Each $\$ 2.00$; 10 for $\$ 17.50$.

Japan Chestnut. A handsome round headed tree, producing very large nuts that find a ready market at good prices. 3 feet. Each $\$ 1.25 ; 10$ for $\$ 10.00$.

Hazelnut. (Filbert). This is the sort usually sold in the fruit stores. 3 to 4 feet. Each $\$ 1.00 ; 10$ for $\$ 8.00$.

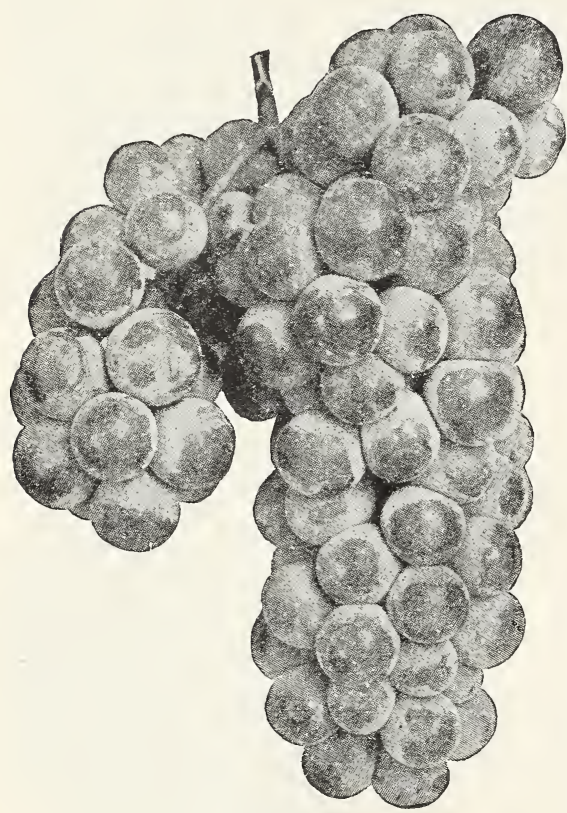

Niagara

\section{GRAPES}

Brighton. (Red.) Bunch large, well formed; berries above medium to large, round; excellent flavor and quality; one of the earlier in ripening. Two-year-old plants. Each $45 c ; 10$ for $\$ 3.75 ; 100$ for $\$ 30.00$.

Campbell's Early. (Black.) Bunch and berry large, glossy black, early and a great bearer. Two-year-old plants. Each 45c; 10 for $\$ 4.00$; 100 for $\$ 25.00$

Concord. (Black.) The well known standard variety. It succeeds wherever grapes are grown. Two-year-old plants. Each 25c; 10 for $\$ 1.75 ; 100$ for $\$ 10.00$.

Catawba ( $R$ e d.) Dark red when fully ripe. Bunches large: berries medium to large, with rich flavor. Two-year-old plants. Each 35c; 10 for $\$ 3.00 ; 100$ for $\$ 20.00$.

Delaware. ( $R$ e d.) Small, $1 \mathrm{ig} \mathrm{h} \mathrm{t} \mathrm{red,}$ skin thin, very juicy sweet and sprightly one of the finest fla. vored hardy grapes Two-year-old plants. Each 45c; 10 for $\$ 3.75$; 100 for $\$ 30$ !

Diamond. (White) The leading early white grape White, with rich yellow tinge; juicy, few seeds, almost free from pulp, excellent quality hardiness and foliage. Vine like Concord in growth. 'Two-year-old plants. Each 35c; 10 for $\$ 3.00 ; 100$ for $\$ 20.00$.

Niagara. . (White.) Bunch is very large and compact. Sometimes shouldered; berries large; light greenish white; semi-transparent; skin thin, quality good. Two-year-old plants. Each 30c; 10 for $\$ 2.50 ; 100$ for $\$ 18.00$.

Pockington. (Golden Yellow.) Bunch large, very compact. Berries very large, juicy, sweet, with very little pulp. Vine very hardy, even more so than Concord, and produces large crops of fine quality. Two-year-old plants. Each $40 \mathrm{c} ; 10$ for $\$ 3.50 ; 100$ for $\$ 25.00$.

Regal. (Red.) If you want the longest keeping grape, one that you can eat during fall and winter months, plant the Regal. It is of superior quality. Berries are large, dark red, juicy, with a skin thin but tough. Twoyear-old plants. Each $40 \mathrm{c} ; 10$ for $\$ 3.50 ; 100$ for $\$ 30.00$

Worden. (Black). Bunch large, sometimes shouldered, compact; berries very large. Skin thin. Superior to any Concord. Two-year-old plants. Each 30c; 10 for $\$ 2.75$; 100 for $\$ 15.00$.

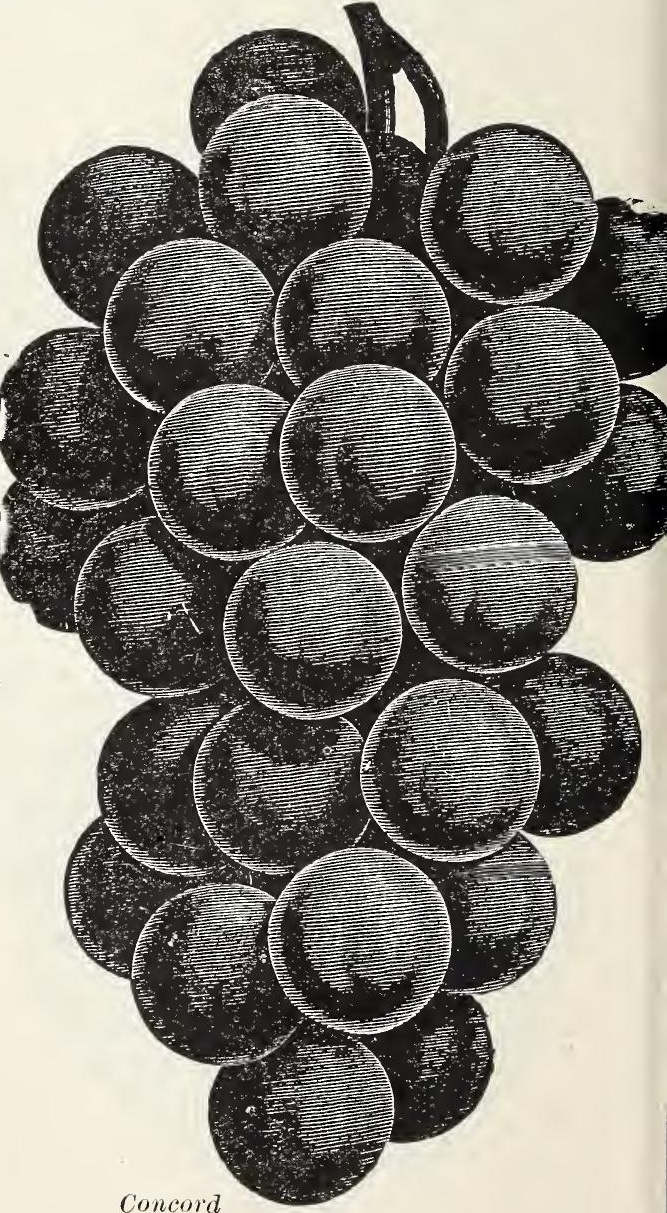




\section{BLACKBERRIES}

Blowers. A mammoth grower and enormously productive. Berries big and luscious. An ironclad variety that never winter-kills. Each 10c; 10 for $90 \mathrm{c} ; 50$ for $\$ 4.50$.

Eldorado. The vines are very hardy and vigorous, enduring the winters of the far Northwest without injury, and their yield is enormous. The berries are large, jet black, borne in large clusters and ripen well together; they are very sweet, melting, have no hard core and keep from eight to ten days after picking. with quality unimpaired. Each 10c; 10 for $80 \mathrm{c} ; 100$ for $\$ 6.00$.

Snyder. This is one of the best blackberries for market in the North; very hardy. The canes are vigorous and annually productive. The berries are medium in size, very sweet, juicy and of fine flavor. It also lacks the hard core of many other varieties. Each 10c; 10 for 90c; 50 for $\$ 4.50$.

\section{STRAWBERRIES}

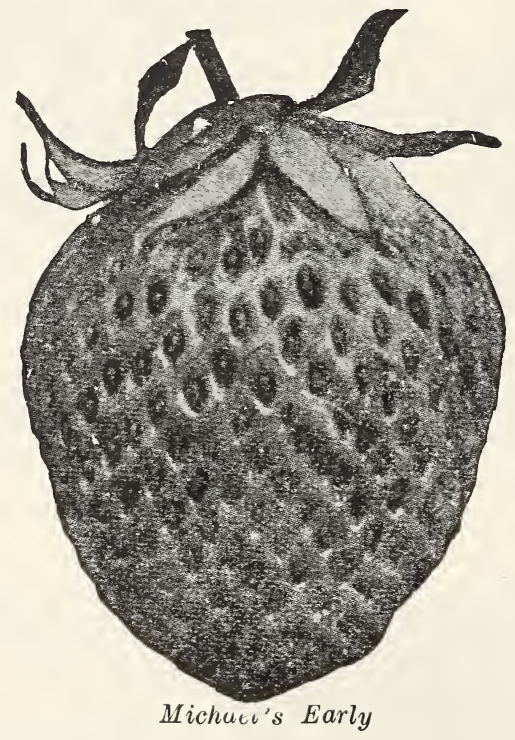

Brandywine. Plants vigorous, large, healthy, hardy and productive. Berries large, roundish, conical, regular; uniform in size, handsome in color and excellent in quality. 10 for $45 \mathrm{c} ; 100$ for $\$ 1.25 ; 1,000$ for $\$ 9.00$.

Michael's Early. One of the earliest varieties grown. Conical in shape, of a rich crimson color, with a rich, mild flavor and deep pink meat. The plant is strong and healthy; one of the best for fertilizing early pilillate varieties. 10 for $45 \mathrm{c} ; 100$ for $\$ 1.25 ; 1,000$ for $\$ 9.00$.

Dr. Burrill. (M) A marvel of productiveness, quality, color, size and firmness. The fruit is very firm and of even shape; dark, glossy red with yellow seeds and green calyx; making a beautiful combination. 10 for $45 \mathrm{c} ; 100$ for $\$ 1.25 ; 1,000$ for $\$ 9.00$.

Wiliam Belt. A vigorous, heavy plant, very thrifty and productive; berries large, conical, uniform in shape, glossy crimson; all ripen without green tips, of good qualitv, and excellent for market and shipping. 10 for $45 \mathrm{c}$; 100 for $\$ 1.25$; 1,000 for $\$ 9.00$.

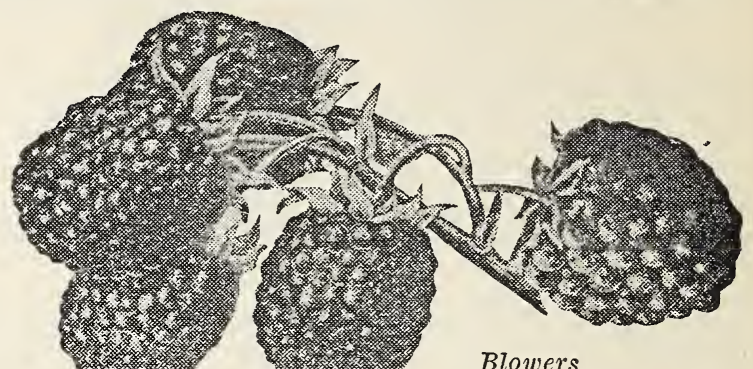

Sample. One of the very best berries and seems to succeed nearly everywhere. Plants strong, large and healthy, producing in profusion large, dark colored berries of uniform size and color; firm enough to ship well. One of the standard sorts for both home and market. 10 for $45 \mathrm{c} ; 100$ for $\$ 1.25 ; 1,000$ for $\$ 9.00$.

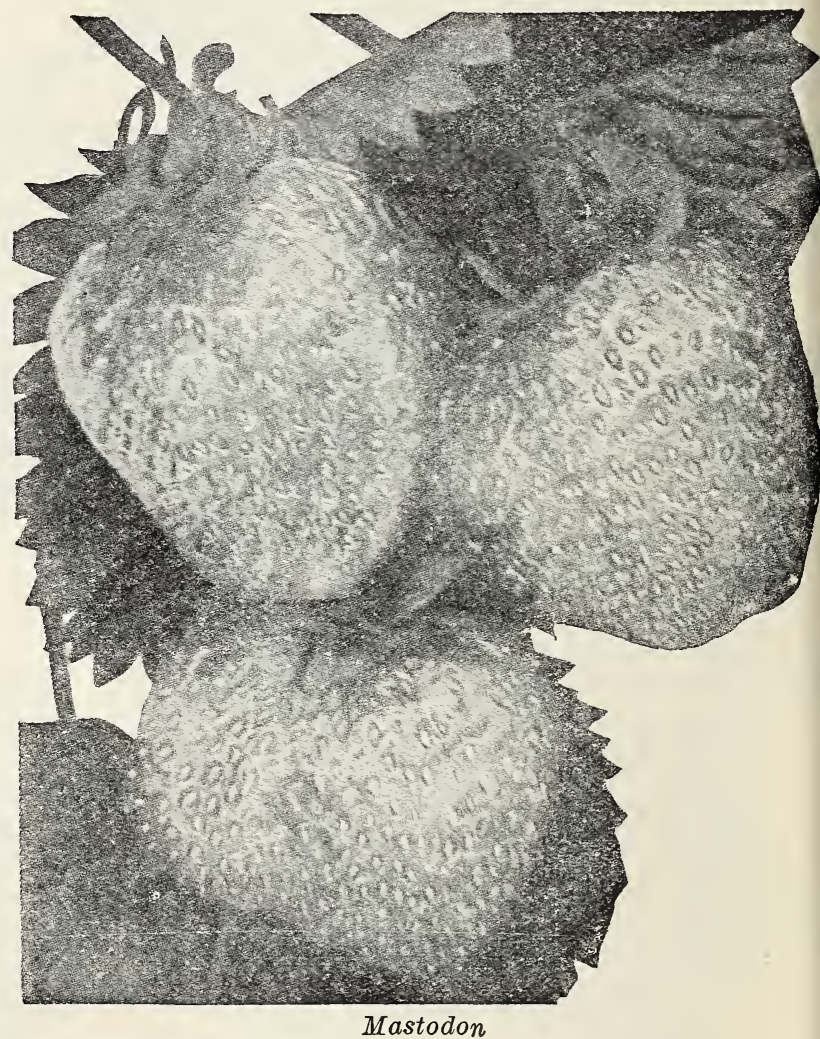

Mastodon. Since introduction of the Everbearing class, many varieties have been tried, improved and supplanted. According to many reports gathered from all berry-growing sections of the cuuntry, Mastadon is the last word and outranks all predecessors. It is of immense size, an almost incredible cropper, of choice quality, and the strongest grower yet developed. More productive than most June bearers; its tall pickings are sufficient from but a few plants, and very profitable. 25 for $\$ 1.50 ; 100$ for $\$ 4.00$. By Express, 1000 for $\$ 30.00$. 


\section{VEGETABLE SEEDS}

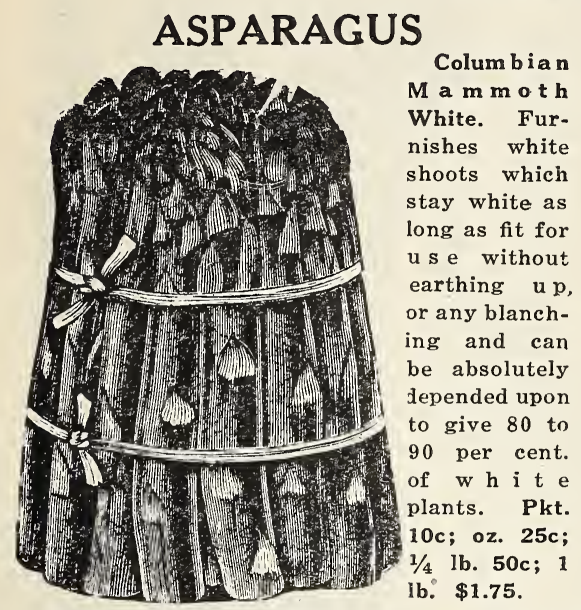

BUSH BEANS (Green Podded)

Black Valentine. This excellent variety is a great improvement over the old standard early Red Valentine, being one-third longer than that variety, with pods perfectly round and straight and of excellent quality. It also has the additional advantage of being suitable for both early and late planting and is extremely hardy. Pkt. 10c; $1 \mathrm{lb} .45 \mathrm{c}$; 2 lbs. 80c. By Express, 10 lbs. $\$ 3.00$.

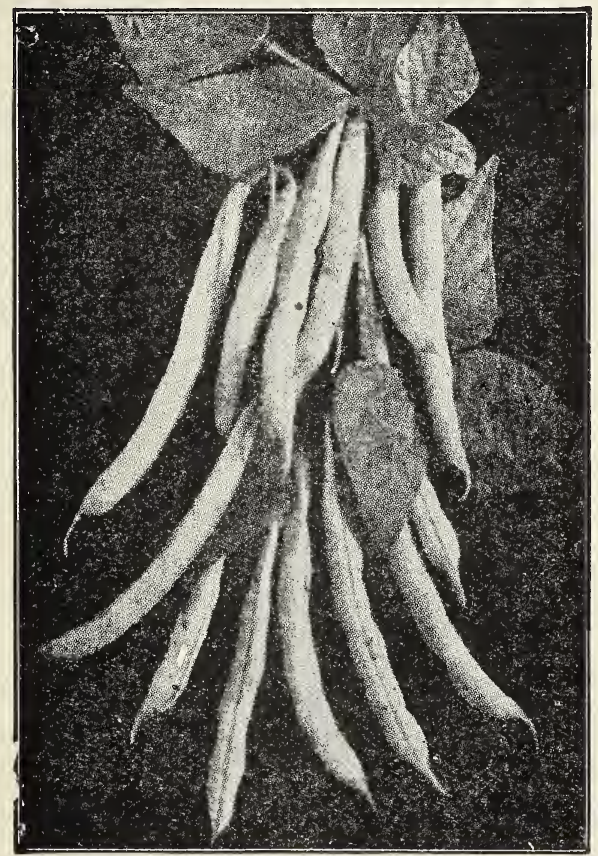

Early Yellow Six Weeks

Extra-Early Red Valentine. Large and productive; pods very fleshy and free from strings. Pkt. 10c; lb. 40c; 2 lbs. 75c. By Express, 10 lbs. $\$ 3.00$.

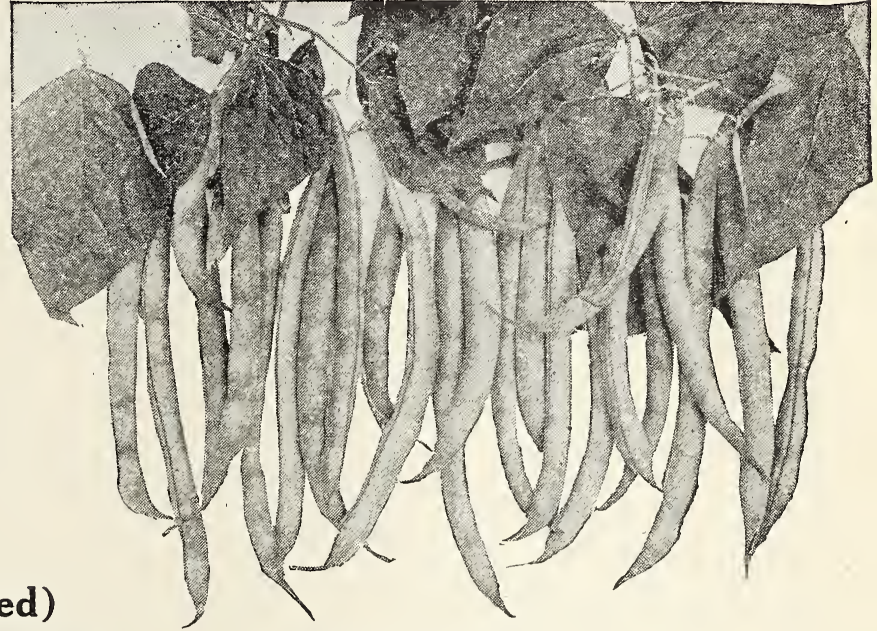

Stringless Green Pod

Giant Stringless Green Pod. The vines are of robust growth, very prolific and produce the pods in wonderful profusion. The pods are extra long, round and fleshy, very tender and absolutely stringless. As an early snap bean, and for canning purposes it is unexcelled. In our trial grounds it proved to be one of the very best beans. Pkt. 10c; $1 \mathrm{lb}$. 50c; 2 lbs. 90c. By Express, 10 lbs. $\$ 3.50$.

White Navy or Pea Bean. This is used mostly for field planting and is probably one of the best sorts for this purpose. The variety is considered to be a sure cropper and extremely prolific. Medium size when shelled and round and clear white. Pkt. 10c; lb. 35c; 2 lbs. 60c. By Express, 10 lbs. \$2.25.

Early Yellow Six Weeks. Vines large, vigorous branching, productive, with large leaves and lilac blossoms; pods long, straight, narrow, handsome; beans long, kidney-shaped; color yellowish-drab. Pkt. 10c; 1b. 45c; 2 lbs 80c. By Express, $10 \mathrm{lbs}$. $\$ 3.00$.

\section{BUSH BEANS (Yellow Podded or Wax)}

Davis White Wax. This bean is adapted alike for the canner, market gardener, shipper or amateur. The dry bean is large, kidney shaped, and white in color, making it one of the best for cooking in a dry state. Pods are long, meaty, flat in shape, and of a beautiful yellow color and fair quality. Pkt. 10c; lb. 45c; 2 lbs. 80c. By Express, 10 lbs. $\$ 3.00$.

Improved Prolific German Black Wax. A good variety which should be planted in every garden. Pods are quite long, nearly round and well filled with a small black seed. Very tender and of excellent flavor. Pkt. 10c; lb. 40c; 2 lbs. 70c. By Express, $10 \mathrm{lbs}$. $\$ 2.75$. 
Improved Golden Wax. In this variety we have a bean that possesses all the good points of the old favorite, Golden Wax, but is larger in pod and much more prolific; handsome appearance; being of a dark, rich yellow color and of perfect shape. Of grand quality, showing no string or coarseness even when past its best, but is of tender and melting flavor at all stages of its growth. Being so exceedingly prolific, it is not injured by bean rust. For market gardeners or private families no better variety can be planted. Pkt. 10c; 1b. 45c; 2 lbs. 85c. By Express, 10 lbs. $\$ 3.00$.

Round Pod Kidney Wax. Two characteristics of this bean, which make it at once popular upon the first trial, are its freedom from disease and the abundance of pods. The fleshy round pods hang thickly on the plants, are of fine flavor, stringless and free from rust. The pods are of beautiful lemon yellow, larger than those of Wardwells, which mature a few days later. Pkt. 15c; 1b. 50c; 2 lks. 90c. By Express, 10 lbs. $\$ 3.25$.

Wardwell's Kidney Wax. Probably this variety is known to gardeners all over the country, and is one of the hardiest sorts. The plants are rapid growers, coming into full size in a very short time. Seeds are white wi h slight purple tinge. Most desirable in every way. Pkt. 15c; lb. 50c; 2 lbs. 90c. By Express, 10 lbs. for $\$ 3.50$.

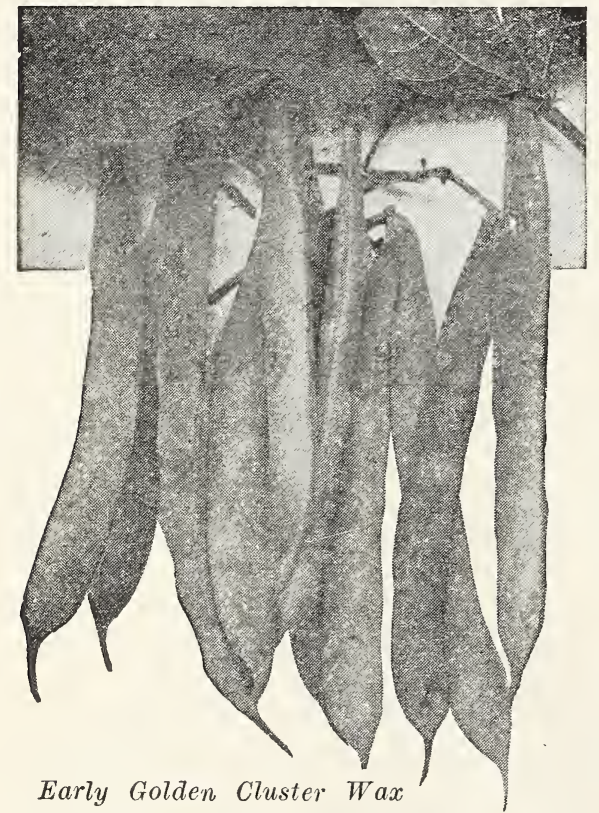

POLE BEANS (Wax and Green Podded)

Early Golden Cluster Wax. It bears profusely its long golden pods in clusters of three to six, from the middle of June till cut by frost. The pods are from 7 to 8 inches long and about an inch in width. They are fleshy, absolutely stringless and very brittle; very attractive and good quality; the beans are white, oval shaped. Pkt. 10c; lb. 50c; 2 lbs. 90c. By Express, 10 lbs. $\$ 3.50$.

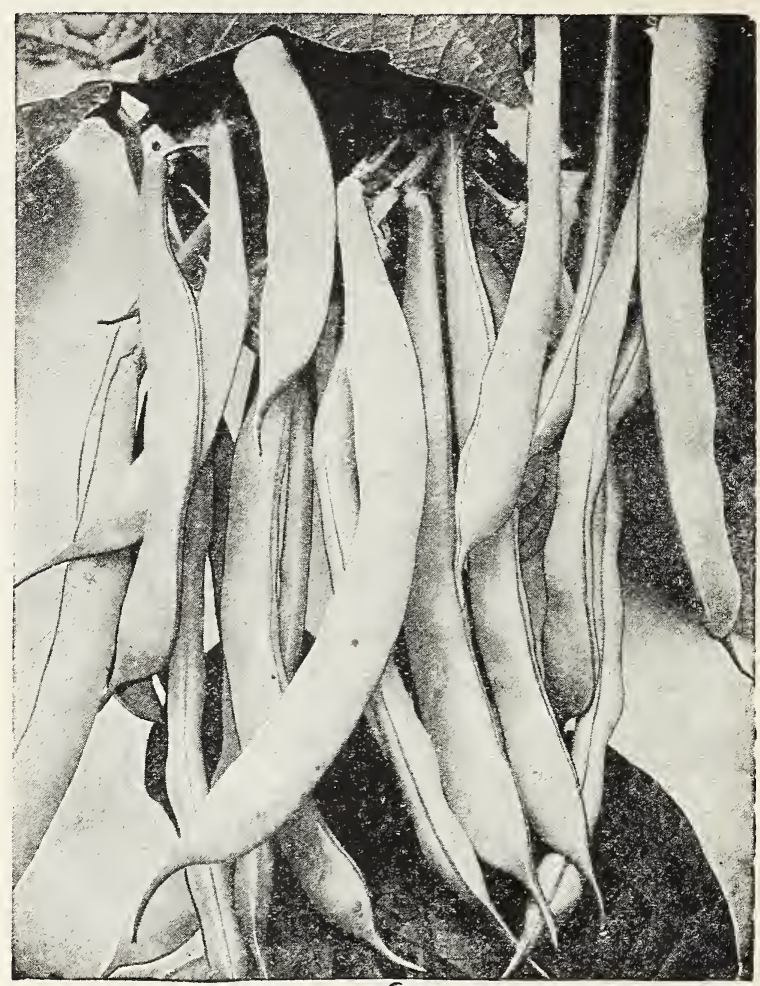

Improved Golden Wax

Lazy Wife. Pods are of good size, entirely stringless, fleshy, of pleasing flavor. Equally good as a snap bean or a winter shell bean. Pkt. 10c; 1b. 40c; 2 lbs. 75c. By Express, 10 lbs. $\$ 3.00$.

Kentucky Wonder. Vine vigorous, climibing well, and very productive, bearing its pods in large clusters; blossoms white; pods green, very long, often reaching 9 to 10 inches. Nearly round when young and very irregular, although as they reach maturity they become irregular and spongy. Dry beans long, oval, dun-colored. Pkt. 10c; 1b. 40c; 2 lbs. 75c. By Express, 10 lbs. $\$ 3.00$.

White Creaseback. An extremely early pole bean, producing an abundant crop of handsome green pods about 6 inches long, perfectly round and stringless. Early and of most excellent quality. The dry beans are pure white, making it an excellent shell bean for winter use. Pkt. 10c; 1b. 40c; 2 lbs. 80c. By Express, 10 lbs. $\$ 3.00$.

\section{POLE LIMA BEANS}

King of the Garden. The old standard of market and family sort. The vine begins to produce pods at the foot of the pole, and the bearing season continues until frost. Pods large, and well filled with beans of mammoth size. Pkt. 10c; lb. 45c; 2 lbs. 80c. By Express, $10 \mathrm{lbs}$. $\$ 3.00$.

Large White Iima or Butter. Productive, large, flat pods, rich and of finest flavor. The dry beans are white. Pkt. 10c; 1b. 45c; 2 lbs. 80c. By Express, 10 lbs. $\$ 2.75$. 


\section{BUSH LIMAS}

Burpees Bush Lima. Bushes grow 18 to 24 inches high, of stout growth and always erect, yet branching so vigorously that each plant develops into a magnificent eircular bush from 2 to 3 feet in diameter. Enormously productive, single plants under favorable circumstances, yielding from 200 to 350 pods. Handsome large pods being filled with very large beans, identical in size and luscious flavor with the well-known pole Limas. Pkt. 15c; lb. 50c; 2 lbs. 90c. By Express, $10 \mathrm{lbs}$. $\$ 3.75$.

Fordhook Bush Lima. Valuable variety on account of its earliness and wonderful productiveness, continuing to grow and set pods until stopped by frost. Rich, buttery Limas, the true flavor (even better). Vines are without runners. Pods short, flat and contain three to five beans. Plkt. 15c; 1b. 50c; 2 lbs. 90c. By Express, 10 lbs. $\$ 3.50$.

\section{TABLE BEETS}

Crimson Globe. An early variety of medium size and globe shaped. Entirely free from rootlets; very smooth and of a rich, deep red color. Flesh is of the finest quality, sweet and tender. Foliage is small and of a bronze purple color. Pkt. $10 \mathrm{c}$; oz. $20 \mathrm{c}$; $1 / 4$ lb. $45 \mathrm{c}$; 1b. $\$ 1.50$.

Datroit Dark Red Turnip. Quality good, sweet and tender; color deep red; roots are turnip shaped, with small tap roots. Pkt. 10c; oz. 20c; $1 / 4$ lb. 45c; 1b. \$1.75.

Early Model. A very early blood-red sort; medium size, almost round; extremely sweet and tender. Pkt. 10 ; oz. 20 c; $1 / 4$ lb. 40 c; 1 b. $\$ 1.25$.

Early Blood Turnips. An excellent $\epsilon$ arly variety, producing a desirable turnin-shaped beet, with both skin and flesh of a deep blood red. Very sweet and tender. Pkt. 10c; oz. 20c; $1 / 4$ lb. $40 \mathrm{c} ; 1 \mathrm{~b}$. $\$ 1.25$.

Half Lrong Blood. One of the best for winter use. The roots are only half as long as the Long Blood, but weigh as much on account of their thickness. Pkt. 10c; oz. 20c; $1 / 4$ lb. $40 \mathrm{c}$; lb. $\$ 1.25$.

Swiss Chard or Spinach Beet. This plant belongs to the Beet family, but the leaves only are used; prepared like spinach. Pkt. 10c; oz. 20 c; $1 / 4$ lb. 45 c; 1 b. $\$ 1.25$.

\section{MANGEL AND SUGAR BEETS FOR STOCK}

Golden Tankard. Best and most popular for dairy farming; a very large, yellow-fleshed sort, said to contain a large amount of sugar; grows largely above ground; is hardy and a heavy cropper. Pkt. $10 \mathrm{c}$; 0z. $15 \mathrm{c} ; 1 / 4$ lb. $30 \mathrm{c} ; 1 / 2$ lb. $50 \mathrm{c} ; 1 \mathrm{~b} .70 \mathrm{c}$. By Express, 10 lbs. $\$ 6.00$.

Yellow Globe. Skin rich orange yellow, flesh white with yellow rings. Sweet and solid. Roots are a true globe shape and a splendid keeper. Pkt. 10c; 0z. 15c; 1/4 lb. 30c; 1b. 60c. By Express, $10 \mathrm{lbs}$. $\$ 6.00$. 


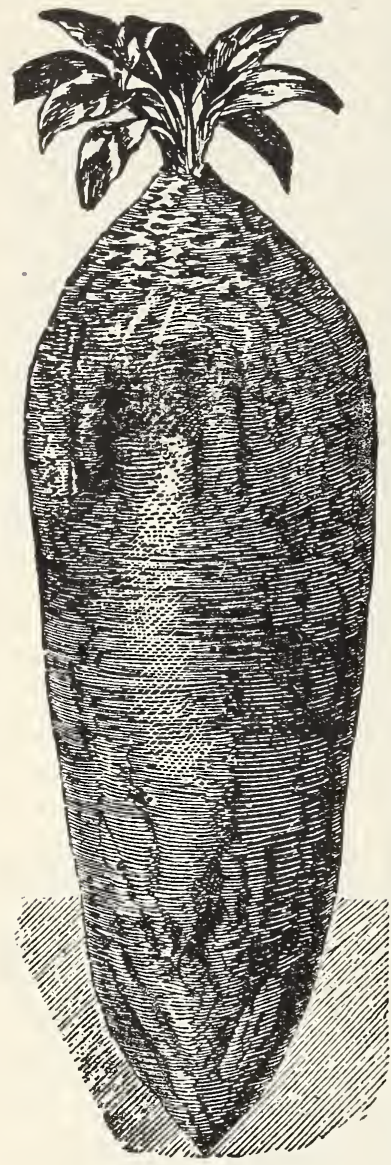

Mammoth Long Red
Ma m moth Long Red. Largest of all Mangels, valuable for stock. The most largely grown of any of the Mangels; roots attain an enormous size, producing 30 to 50 tons to the acre. Pkt. 10c; oz. $15 \mathrm{c} ; 1 / 4$ lb. $30 \mathrm{c} ; 1 / 2$ lb. $50 \mathrm{c}$; 1b. 70c. By Express, 10 lbs. $\$ 6.00$. Klein Wanzleben Sugar. Best beet for sugar-making and largely planted for that purpose. Highly recommended as a winter food for milch cows. Pkt. $10 \mathrm{c}$; oz. 15c; $1 / 4$ lb. 25c; $1 \mathrm{~b}$. 60c. By Express, 10 lbs. $\$ 5.00$.

\section{BRUSSELS SPROUTS}

Improved Dwarf. One of the best vegetables for winter use, producing an abundance of sprouts, resembling small cabbages; of excellent, mild flavor. By sowing in April and planting out in July, it may be had in fine condition until December, and in the South from Novem. ber to March. Pkt. 10c; oz. 50c; $1 / 4$ lb. $\$ 1.50$.

\section{SUMMER CABBAGES}

All Head Early. The earliest flat head, as early as Jersey Wakefield and larger-one-third more than the early pointed heads. Solid, uniform and finely grained heads. Stem is short and extends but little into the head. Pkt. 10c; oz. 35c; 1/4 lb. $\$ 1.00 ; 1 \mathrm{lb}$. $\$ 3.50$.

Copenhagen Market. This variety was introduced about five years ago. The heads are round, and weigh from five to eight pounds each; they are extremely solid, have a very small core, and are of fine quality. It matures with the Wake. fields. The plants are hardy; short-stemmed, produces a head close to the ground. On account of its compact growth it ean be planted closer than most varieties. The finest round-headed early Cabbage on the market. Pkt. 15c; 0z. 60c; $1 / 4 \mathrm{lb}$. $\$ 1.80$; 1b. $\$ 6.00$.

Early Jersey Wakefield. Considered the very best first early variety suited for market and family use. The heads begin to mature the latter part of June and may be solid and conical in shape, with the blunt point, and have but few outside leaves. Pkt. $10 \mathrm{c} ; 0 \mathrm{z}$. $35 \mathrm{c} ; 1 / 4$ lb. $\$ 1.00 ; 1 \mathrm{~b}$. $\$ 3.50$.

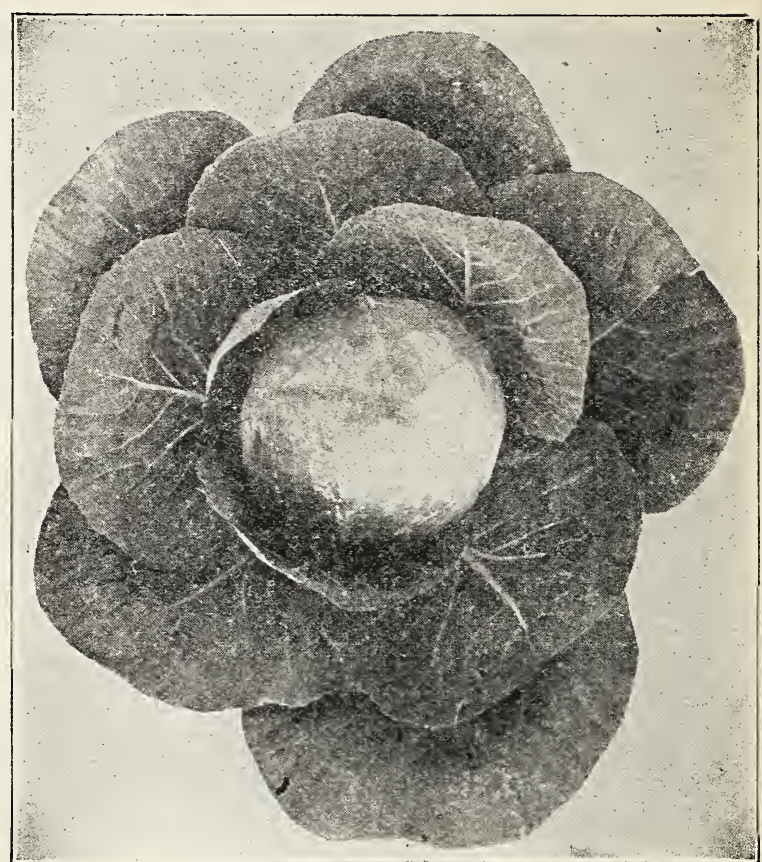

Golden Acre Cabbage

Golden Acre Cabbage. This excellent new variety is the earliest round headed Cabbage. It matures at least 7 days ahead of the earliest strains of Jersey Wakefield, considered the standard early of the country. The heads of Golden Acre are perfectly round, firm, and of exceptionally fine texture, heavy mid-ribs being entirely absent. They average in weight about 4 lbs. and produce very few outer leaves, permitting close planting in the row. Pkt. $15 \mathrm{c}$; ounce $(1-16 \mathrm{lb}$.) $80 \mathrm{c}$; $1 / 4$ lb. $\$ 2.00$; $1 / 2$ lb. $\$ 3.50$; lb. $\$ 8.00$.

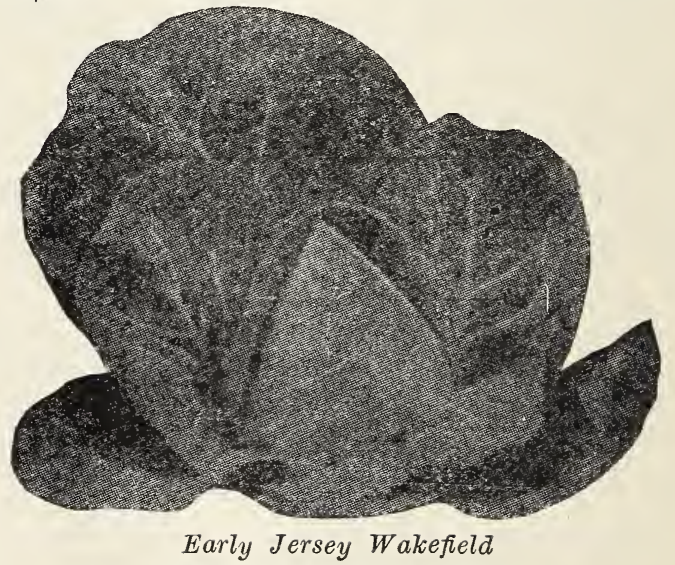

RED CABBAGE

Mammoth Red Rock. The largest and surest heading of red cabbages. The plant is of vigorous growth and forms round, solid heads of deep red color. In quality and flavor is considered to surpass any green cabbage. Pkt. 10c; oz. 50c; $1 / 4$ lb. $\$ 1.25$; lb. $\$ 4.00$.

\section{SAVOY CABBAGE}

Drumhead Savoy. This is the best of the Savoys for market or family use; heads large with crisp, wrinkled leaves; it nearly approaches the cauliflower in fine flavor. Pkt. 10c; oz. 50c; $1 / 4$ lb. $\$ 1.50$; lb. $\$ 3.50$. 


\section{Winter Cabbages}

Danish Ball-Head or Holland. Genuine and true stock grown in Denmark. The variety known as Ball-Head has been selected and perfected for more than 50 years by the Danish gardeners who prize it so highly that they grow it almost exclusively for winter cabibage. It will stand long journeys and keep far into spring, and is of most rich, mild flavor. Pkt. 15c; oz. 50c; $1 / 4$ lb. $\$ 1.50$; lb. $\$ 4.75$.

Premium Late Flat Dutch. As a variety for winter market it has no superior. Heads are large, bluish green, round, solid, broad and flat on top; they open white and crisp, are tender and well flavored. It is a fall and winter variety, and one of the very best to keep. Pkt. 10c; oz. 35c; $1 / 4$ lb. $\$ 1.00 ; 1 \mathrm{lb} . \$ 3.00$.

Sure Head. A well known variety producing very large, round heads, slightly flattened and is remarkable for its certainty to head. A vigorous grower and one of the best cabbages for late or main crop. Pkt. 10c; oz. 40c; $1 / 4$ lb. $\$ 1.25 ; 1 \mathrm{lb}$. $\$ 3.50$.

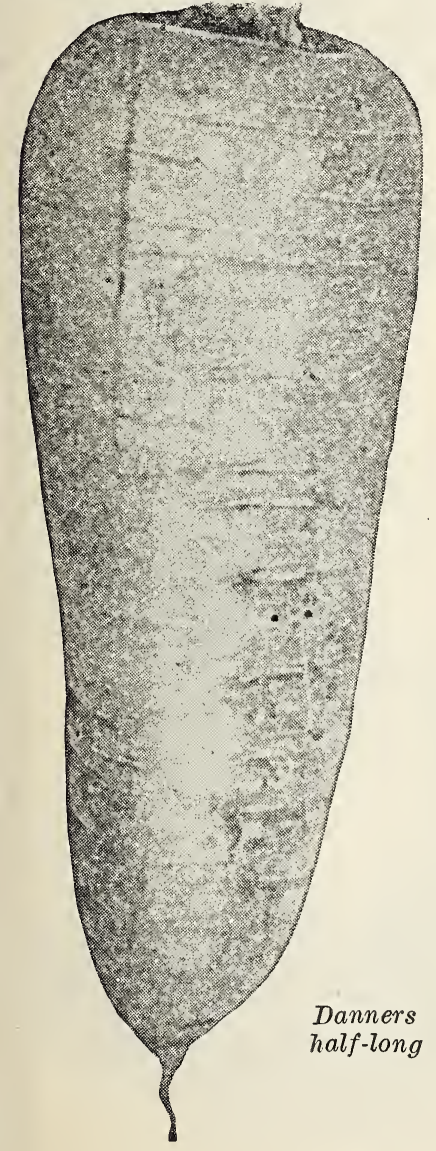

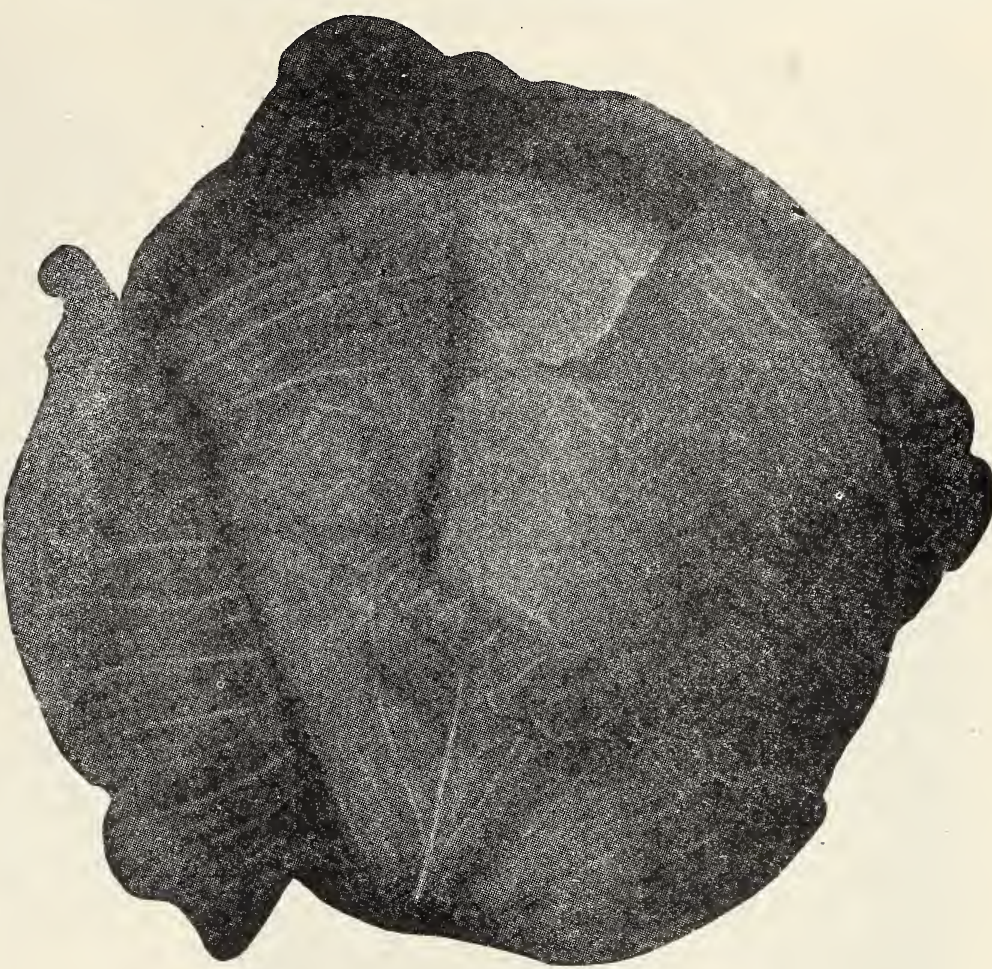

Danish Ball-Head

\section{CARROTS}

Danver's Half-Long. Valuable sort. The standard sort; midway between Long Orange and Early Horn, color bright orange yellow, growing very smooth and handsome, yielding from 20 to 25 tons to the acre. Pkt. $10 \mathrm{c} ;$ oz. $25 \mathrm{c} ; 1 / 4 \mathrm{lb}$. 50c; lb. $\$ 1.50$.

Long Orange. Grows to a large size, is of rich orange color and fine quality. Very desirable for table use and stock. Pkt. 10c; oz. 25c; 1/4 lb. $50 \mathrm{c} ; 1 \mathrm{~b} . \$ 1.50$.

Oxheart or Guerande. A thick earrot, 5 inches long and very blunt at the lower extremity. It grows very rapidly and the roots attain a weight of more than a pound. It is tender, of good flavor and of a deep red color, and is a variety we can recommend for the home garden, as well as to all market gardeners. See eut. Pkt. 10c; oz. $20 \mathrm{c} ; 1 / 4 \mathrm{lb} .40 \mathrm{c} ; 1 \mathrm{~b}$. $\$ 1.25$.

Chantenay or Model. These carrots have attained such a uniformity that they are almost duplicates of each other. Very productive, always smooth and fine in texture. The flesh is of a beautiful deep golden orange. Pkt. $10 \mathrm{c}$; oz. 25c; I/4 lb. 50c; lb. $\$ 1.50$.

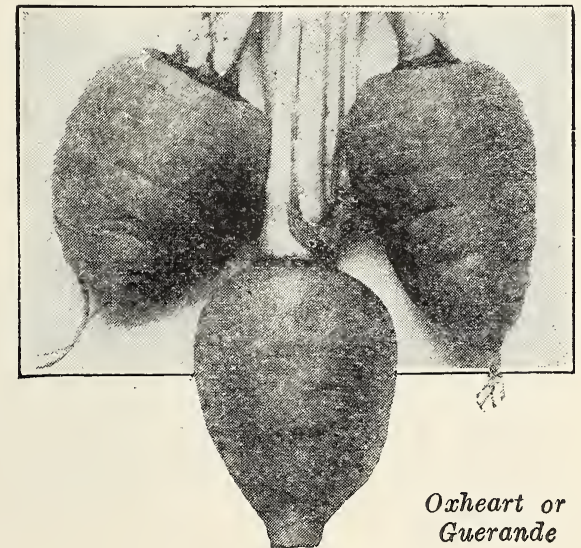




\section{CAULIFLOWER}

Early Snowball. This standard variety is known everywhere, either in the home garden or with the market gardeners. Producing large, solid, white heads when conditions are ordinarily favorable. Averaging about 9 inches in diameter. The solid white heads are so compact that they often outweigh many of the other varieties. Being one of the earliest strains of cauliflower, it becomes one of the most popular sorts, either fancy or for forcing under glass during winter and spring, or for planting in the open ground. Pkt. 25c; $1 / 2$ oz. $\$ 2.00 ;$ oz. $\$ 3.00$.

Danish Giant. An ideal variety for summer use, as it will stand more drought and heat than most other sorts; the heads are snow white. Pkt. 20c; 1/2 oz. \$1.75; oz. $\$ 2.75$.

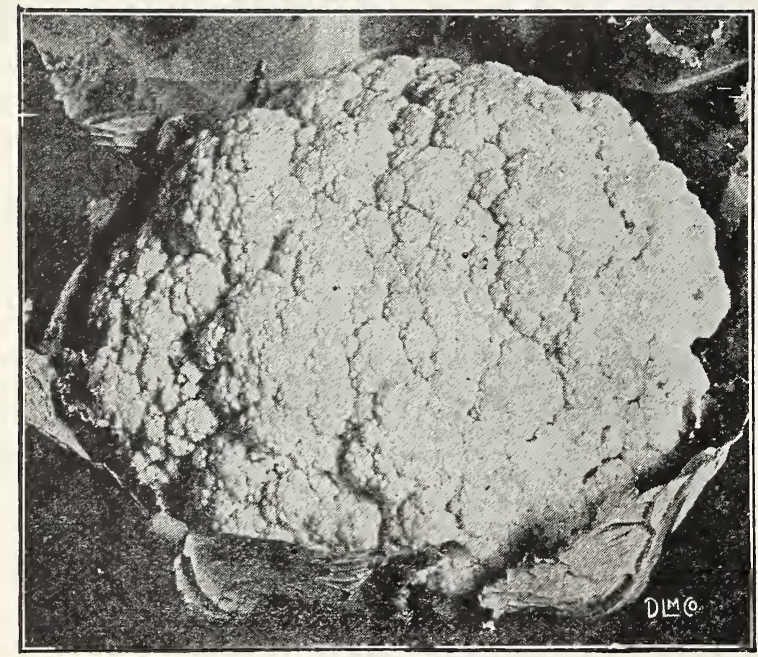

Early Snowball

\section{GERMAN CELERY OR CELERIAC}

Large Smooth Prague. An improved form of turnip rooted celery, excellent for soups and stews. Produces roots of nearly globular shape and comparatively smooth surface. Pkt. $10 \mathrm{c}$; 0z. 50c; $1 / 4$ lb. $\$ 1.25$; 1b. $\$ 4.00$.

\section{CELERY}

Columbia. An early maturing sort, unsurpassed in shape and quality. The plant is of medium height, but very stocky and heavy. The stalks are thick, almost round, resembling in shape those of Giant Pascal. Pkt. 10c; 0z. 35c; 1/4 lb. \$1.25.

Golden Self-Blanching. Grows to a very large size and is very stocky and robust. The stalks grow vigorously, with large ribs, thickly and closely set. It is entirely self-blanching. Pkt. 15c; oz. $75 \mathrm{c} ; 1 / 4 \mathrm{lb}$. $\$ 2.00$.

Giant Pascal. This is, without doubt, the most valuable variety of celery for winter and spring use ever introduced, developed from the Golden Yellow SelfBlanching, and is an excellent sort for fall and winter use. Pkt. 10c; 0z. 35c; $1 / 4$ lb. $\$ 1.25$.

Winter Queen (140 days). This is one of the finest varieties for winter use. Makes a stocky, vigorous growth, which blanches easily. Hearts are large and solid but very crisp and tender. Pkt. 10c; oz. 35c; 1/4 1b. $\$ 1.25$.

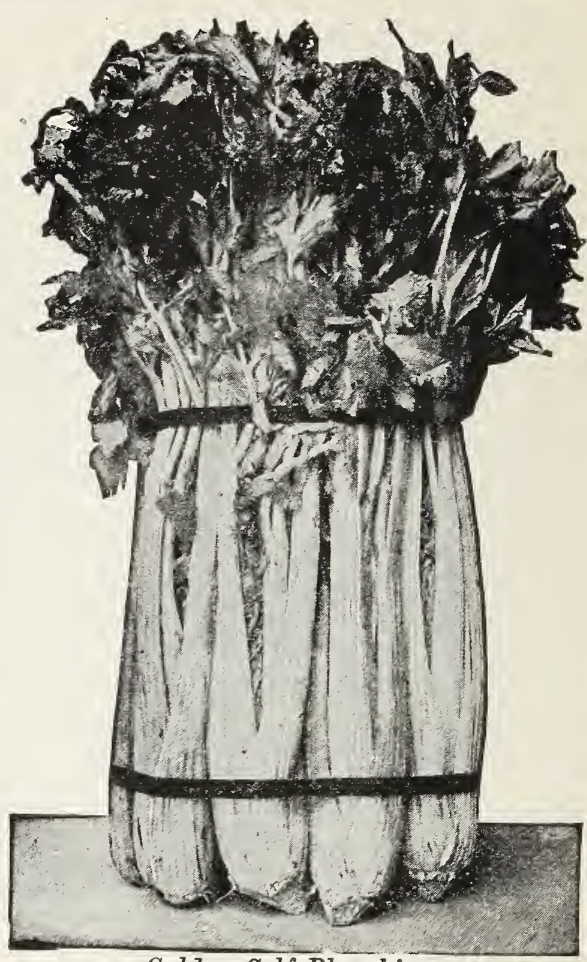

Golden Self-Blanching

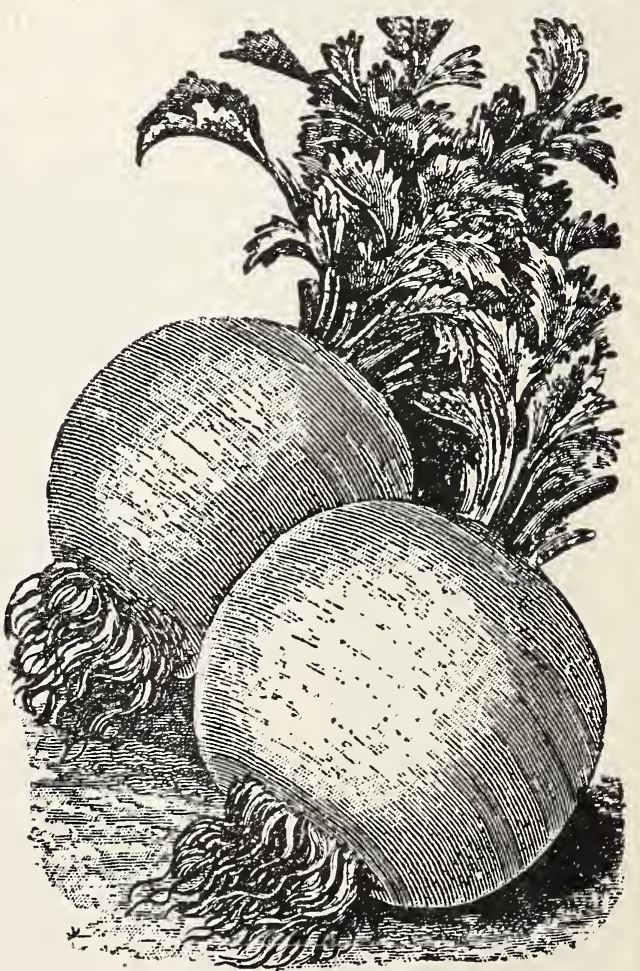

Large, Smooth Prague 


\section{SWEET CORN}

Black Mexican. Probably the sweetest of all the Sweet Corns. The ear is mottled with blaci and white grains, the darker grains becoming a violet shade when cooked. A splendid sort for the home garden, but on account of the color does not have large sale in the market. Pkt. 10c; lb. 40c; 2 lbs. 75c. By Express, 10 lbs. $\$ 2.50$.

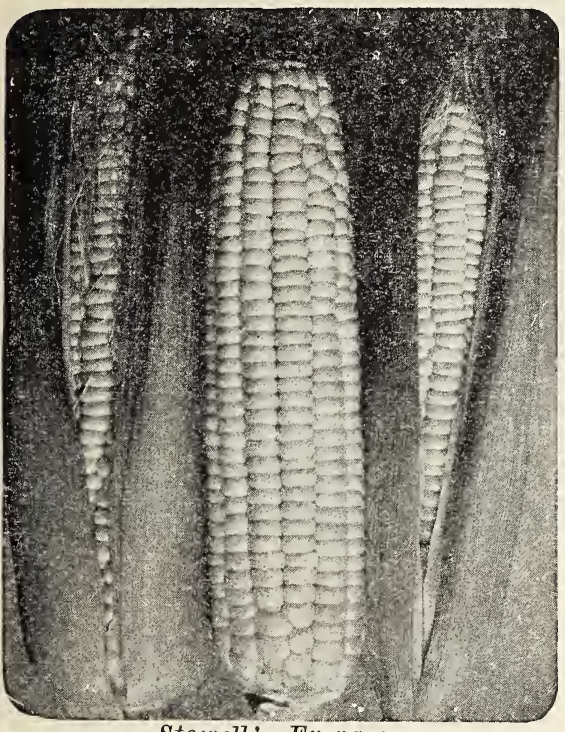

Stowell's Evergreen

Country Gentleman. One of the best. Ears rather short, but thick and set with deep grains in irregular rows; grains are white, sweet and of fine quality. Ripens a little earlier than Stowell's Evergreen. Pkt. 10c; lb. 40c; 2 lbs. 75c. By Express, 10 lbs. $\$ 2.50$.

Early Mammoth White-Cory. A most excellent, large and very early sort; ears double the size of the old Cory, retaining their fine, pure white color when cooked; cobs pure white, thus giving the ears no dark tinge. Pkt. 15c; lb. 45c; 2 lbs. 80c. By Express, 10 lbs. $\$ 3.00$. Early Golden Bantam. A very early sweet corn with golden yellow grain, very tender and of excellent quality. The ears are eight rowed, 6 to 7 inches long and of the medium size found most suitable for the table. Pkt. 15c; lb. 40c; 2 lbs. 75c. By Express, 10 lbs. $\$ 3.00$.

Howling Mob. This is one of the newer varieties that has become very popular by reason of its many good points. It is the largest eared of all the early sorts and usually produces two ears to the stalk. The ears are from 7 to 9 inches long. Pkt. 10c; lb. 40c; 2 lbs. 75c. By Express, 10 lbs. $\$ 2.50$

Stowell's Evergreen. The standard variety. Very productive, ears are large, and deep grained, exceptionally tender and sugary, and remain long in edible condition. Pkt. 15c; lb. $40 \mathrm{c} ; 2$ lbs. $75 \mathrm{c}$. By Express, 10 lbs. $\$ 3.00$.

\section{POP CORN}

White Rice. The most popular for general use. Pkt. 10c; lb. 35c; 2 lbs. 60c.

\section{CUCUMBERS}

Boston Picklin. This is a very prolific cucumber, largely planted for pickles. The fruits average 4 to 6 inches in length when large enough for slicing, and are of excellent quality. It is, however, for producing medium-sized pickles that this variety is so highly esteemed. Pkt. $10 \mathrm{c} ; 0 \mathrm{z} .25 \mathrm{c} ; 1 / 4 \mathrm{lb} .50 \mathrm{c} ; 1 \mathrm{lb}$. $\$ 1.75$.

Chicago Pickling. Fruit of medium length, pointed at each end with very large and prominent spines, color deep green. Pkt. 10c; 0z. 25c; 1/4 1b. 50c; 1b. $\$ 1.75$.

Davis Perfect. A first class variety forcing under glass; also for outdoor culture, and shipping. The color is a dark, glossy green, long, slim in shape. It is tender and of exceptionally good flavor. Pkt. $10 \mathrm{c} ;$ oz. $25 \mathrm{c} ; 1 / 4$ 1b. 75c; 1b. $\$ 2.00$.

Improved Long Green. A standard main crop variety, about 9 inches long. of excellent quality, and makes the best pickles. Also one of the best for slicing, being tender, crisp and of fine flavor. Pkt. 10c; oz. 25c; 1/4 1b. 50c; 1b. $\$ 1.75$.

Improved White spine. This variety comes in bearing early and produces straight light green cucumibers that are crisp and tender. Pkt. 10c; oz. 25c; 1/4 lb. $50 \mathrm{c} ; 1 \mathrm{~b}$. $\$ 1.75$.

Klondike. A medium early, white spined of handsome, very dark green color and of excellent quality for slicing. The vines are very hardy and productive, the fruits when mature are about 8 inches long, and are uniform in size and shape. Pkt. 10c; 0z. 25c; 1/4 lb. 50c; lb. $\$ 1.75$.

Everbearing. This is a very early and extremely prolific variety. If the fruits are kept gathered, vines will continue in bearing throughout the season. The fruits, of a rich dark green color, average from 4 to 5 inches in length by an inch and a half in diameter. It is an excellent variety for producing small pickles. Pkt. 10c; 0z. $25 \mathrm{c} ; 1 / 4$ lb. $50 \mathrm{c}$; 1b. $\$ 1.75$.

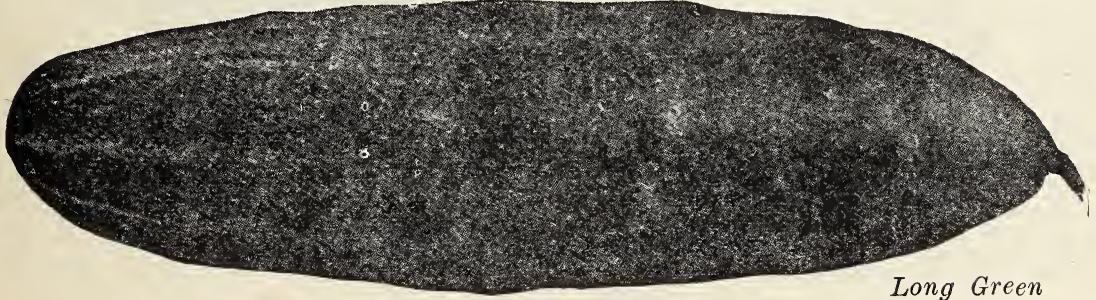

Early Golden Bantam

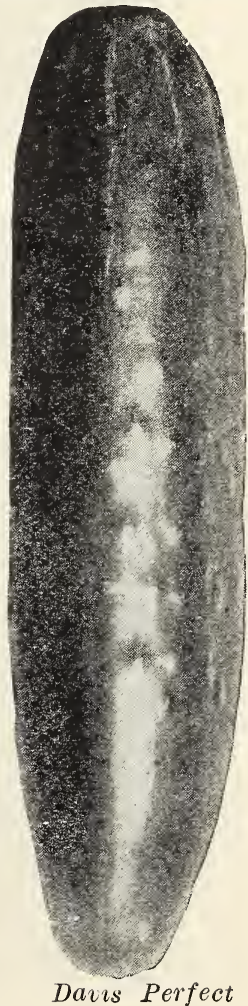




\section{EGG PLANT}

New York Improved Egg Plant. (Spineless.) A vigorous grower; fruit large, fine, free from thorns, and produce until frost; skin of a rich purple, flesh white and of a rich flavor. We can highly recommend this Egg Plant. Pkt. 10c; 0z. $75 \mathrm{c}$.

\section{ENDIVE}

Green Curled winter. The hardiest variety; leaves dark green which readily blanch white; not only most useful as a salad, but much used for garnishing. Pkt. $10 \mathrm{c} ;$ oż. $40 \mathrm{c}$.

\section{KOHLRABI}

White Vienna. Probably the hardiest of the tender and of delicate flavor. Better tasting than turnips. Pkt. 10c: oz. 35c; $1 / 4$ lb. $\$ 1.00$.

Early Purple Vienna. Bluish purple; similar to above except in color. Flesh white. Pkt. 10c; oz. 35c; 1/4 lb. $\$ 1.00$.

\section{IATE WINTER WHITE}

\section{GOLIATH KOHLRABI}

Fine type, white, grows much larger than early varieties. Should be used when young, all varieties are tough when overgrown. Pkt. 15c; oz. 40c; r/4 1b. \$1.25.

Late Winter Purple Goliath. Fine purple type, similar to the above except in color, flesh white. Pkt. 10c; oz. 30 c; $1 / 4$ lb. $\$ 1.00$.

\section{E T T U C E}

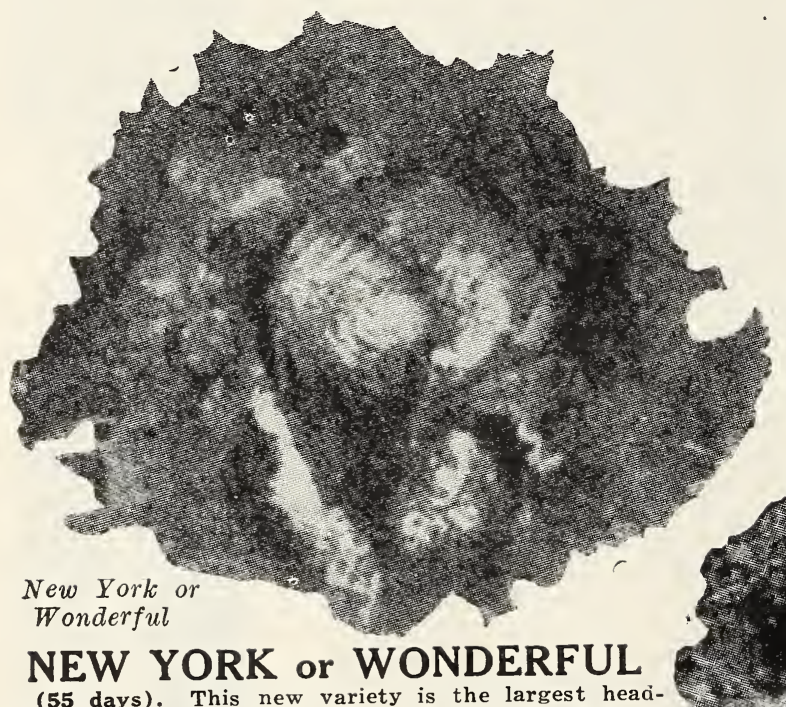

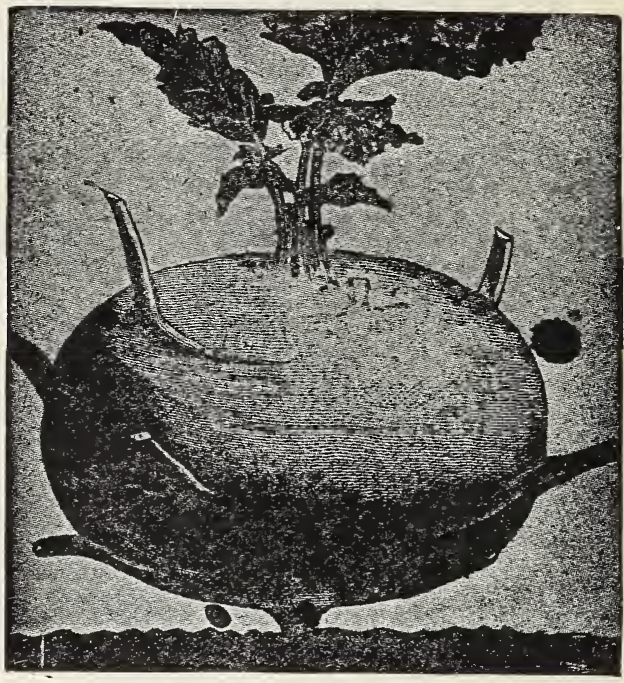

White Vienna

Brown Duth. This is a very good variety. Makes a round head tinged with red. Pkt. 10c; oz. 30c; $1 / 4$ lb. 65c; lb. $\$ 2.00$.

Big Boston. Popular for outdoor culture; also much in demand as a compact, large heading, forcing sort. Plants large, very hardy and vigorous. Leaves broad, comparatively smooth, but wavy at edge, thin, very hard and crisp; color bright light green, the head slightly tinged with reddish brown. Pkt. 10c; oz. $30 \mathrm{c}$; $1 / 4$ lb. 60c; lb. $\$ 2.00$.

California Cream Butter. A grand, good butter lettuce. Pkt. 10c; oz. 30c; 1/4 lb. 90c; lb. $\$ 2.00$.

Denver Market. Early head lettuce, good either for forcing or open ground. The leaves are beatifully crimpled and curled like the Savoy cabbage; very crisp, tender, of excellent flavor. Pkt. 10c; oz. 30c; $1 / 4$ lb. 65 ; lb. $\$ 2.00$.

(5) 18 inches across. and are searticularly andid and colored a tempting light gween. Unrivalled for long season; crisp, tender and delicious. Pkt. 15c; oz. $50 \mathrm{c} ; 1 / 4 \mathrm{lb}$. $\$ 1.50 ; 1$ lb. $\$ 5.00$.

May King. A very early variety of head lettuce of compact growth. The inner leaves are of a bright yellow, the outer ones a light green, sometimes slightly yellow, the outer ones a light green, sometimes slightly is in quick and rapid growth, making it extremely tender and brittle. Pkt. 10c; oz. 30c; 1/4 lb. 65c; lb. \$2.00.

winter Lettuce. A light green, loose heading, medium sized let uce; very hardy and when wintered over one of the earliest to mature its head. Pkt. 10c; oz. $30 \mathrm{c} ; 1 / 4$ lb. $50 \mathrm{c}$; 1b. $\$ 2.00$.

Grand Rapids. This is especially adapted for greenhouse cultivation for the winter markets. It is, likewise, a good variety for sowing in the early spring. It does not form a solid head like many other varieties, but throws up large compact bunches of crinkly leaves. It is a rapid grower, keeps in good condition for a long time, and therefore is one of the best sorts for shipping. Pkt. 10c; oz. 30c; $1 / 4$ lb. 65c; lb. \$2.25.

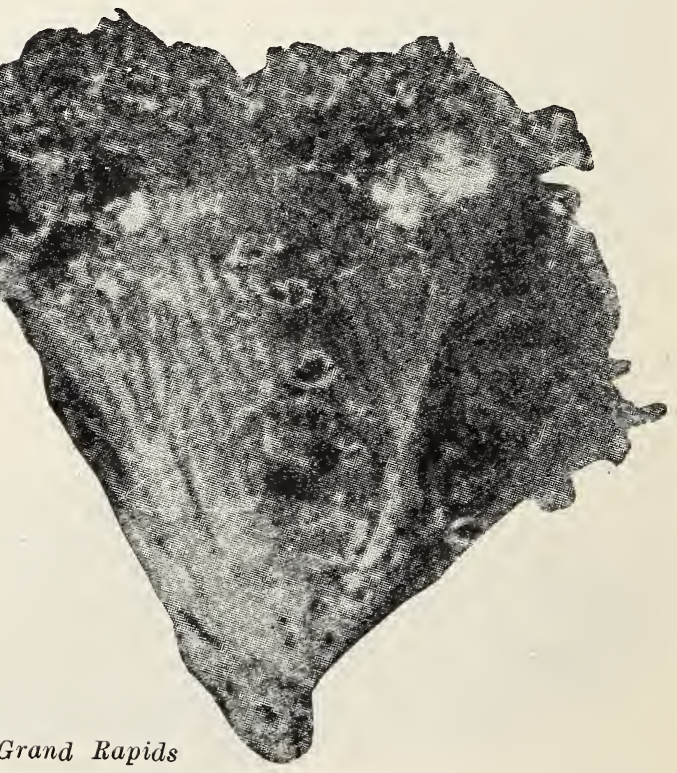


WATERMELON

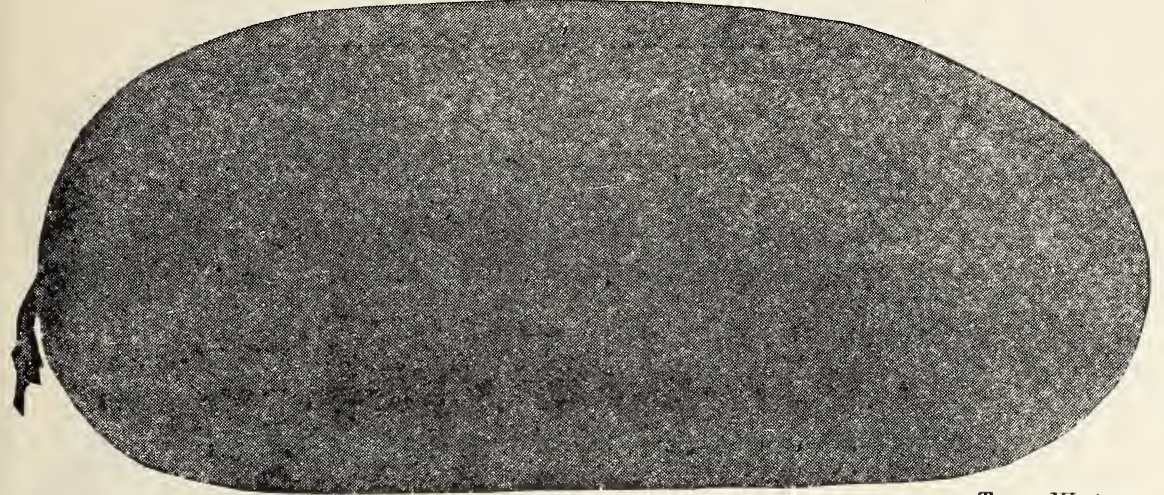

Tom Watson
Tom Watson-A new large, long $\mathrm{m}$ e $10 \mathrm{n}$ weighing from 40 to 60 pounds. The dark green rind is thin but tough, and makes an excellent shipping as well as market and home melon. The $d$ e e p red flesh is $\mathrm{sw}$ e e t, crisp, melting and of finest flavorheart large, with no sign of core. Pkt. 10c; 0z. 20c; $1 / 4$ lb. 50c; lb. $\$ 1.50$.

Harris' Earliest. (60 days). In this melon we offer the best variety for northern latitudes. It is the largest and sweetest of the early melons. Oval to oblong in shape, flesh bright red and tender, very sweet and delicious. The fruits are green striped with gray, and attain a weight of twenty to thirty pounds. Firm hard rind, shipping well. Pkt. 10c; oz. $20 \mathrm{c} ; 1 / 4$ lb. 50c; 1b. $\$ 1.75$.

Hungarian Honey. (Early). The flesh is brilliant red and of a rich honey flavor; uniform in size and perfectly globe-shaped; verage weight ten pounds. Pkt. 10c; oz, 20c; 1/4 lb. 60c; lb. $\$ 2.00$

Sweetheart. New. Globular in shape; skin very bright, mottled green; flesh bright red, firm and heavy, but crisp, melting and exceedingly sweet. Pkt. 10c; oz. 20c; $1 / 4$ lb. 50c; lb. $\$ 1.50$.

Iceburg Blue Gem. Often called Blue Gem. Has a very firm, hard rind and it is as good a shipper as the Kolb's Gem, but the flesh is much deeper colored, extends nearer to the rind, is much more tender and sweet. Pkt. 10c; oz. 20c; 1/4 lb. 50c; lb. $\$ 1.50$.

Dixie. Beautifully striped. The flesh is an intense bright deep scarlet, sweet and tender. Pkt. 10c; oz. 20c; $1 / 4$ lb. 50c; lb. $\$ 1.50$.

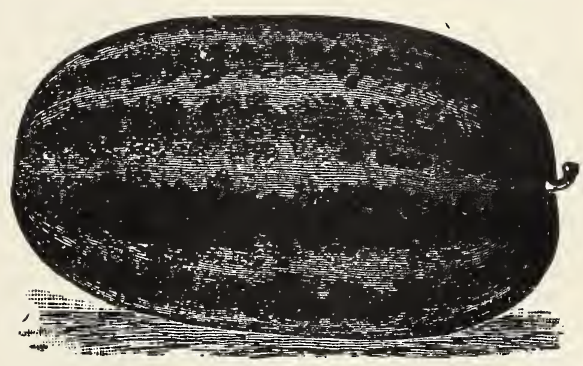

Harris Earliest

\section{MUSK MELON}

Banana. (85 days.) Makes a long banana-like growth, very fragrant and of delicious flavor. Excellent for the home garden. Pkt. 10c; oz. 20c; 1/4 lb. $60 \mathrm{c} ; 1 \mathrm{~b} . \$ 2.00$.

Rocky Ford. This variety is in great demand by the high-class hotels and restaurants. Just the right size for table use, slightly oval in shape, flesih thick, of light green color, and fine, juicy, luscious flavor. Very early and wonderfully produc $\mathrm{t}$ i v e. Pkt. 10c; oz. 25c; $1 / 4$ lb. 60 ; ; lb. $\$ 2.25$.

Osage. (Selected.) Of uniform quality, sweet and delicious. The skin is thin, dark green and slightly netted; the flesh deep salmon, of spicy flavor. A good keeper and largely planted. Pkt. 10c; oz. 25c; $1 / 4$ lb. $60 \mathrm{c}$; lb. $\$ 2.25$.

Tip Top. Very productive, medium size, nearly round, slightly ribbed and fairly well covered with shallow netting; flesh deep yellow. Pkt. 10c; oz. 25c; $1 / 4$ lb. $60 \mathrm{c} ; 1 \mathrm{lb}$. $\$ 2.25$.
Early Hackensack. A very large, green fleshed melon. The vine's fruits are nearly round, usually somewhat flattened; ribs large and of irregular width, densely covered with coarse netting. Pkt. $10 \mathrm{c}$; 0z. $25 \mathrm{c}$; $1 / 4$ lb. $60 \mathrm{c}$; 1b. $\$ 2.00$.

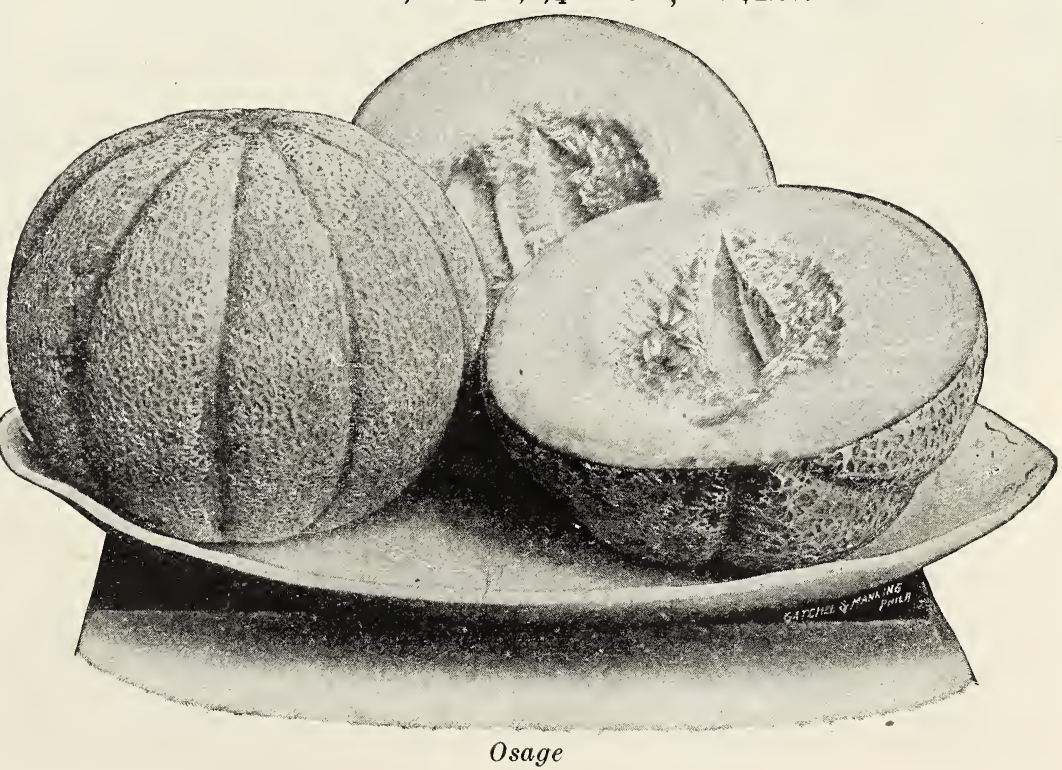




\section{MUSHROOIMS}

Can be easily grown by anyone who has a cellar, or dark room, where the temperature can be kept at from 50 to 60 degrees. The soil should be a sandy loam, if possible to procure it, but if not, secure the top-soil from an old pasture. To every bushel of soil add about two bushels of fresh horse manure, thoroughly mixing both; then prepare a bed three feet wide, put down a thin layer of the mixture, pack in hard and keep on with this method until the bed is about 8 inches thick. When the temperature in the bed goes down to about 85 degrees, make holes about 8 in. apart and put in small pieces of spawn. Cover the holes, press the soil lightly; at the end of ten or twelve days cover the bed with fresh soil only, and on top of this put 4 or 5 inches of hay or straw. If an even temperature is maintained you may expect to gather Mushrooms in from six to eight weeks, and the bed will continue to produce for nearly a month.

It comes in pressed bricks weighing about 20 ounces. These are broken into pieces the size of a walnut and put into the bed eight inches apart each way. One brick 50c. By Express: 5 bricks $\$ 1.75$.

\section{MUSTARD}

Fordhook Fancy. (50 days). This is the finest of all mustard, curled like an ostrich plume. In fact, it is sold sometimes under the name of "Ostrich Plume;" splendid flavor, can be cooked any time of the year just like spinach, and by many is considered far superior. Pkt. $10 \mathrm{c}$; 0z. $25 \mathrm{c} ; 1 / 4 \mathrm{lb} .80 \mathrm{c}$.

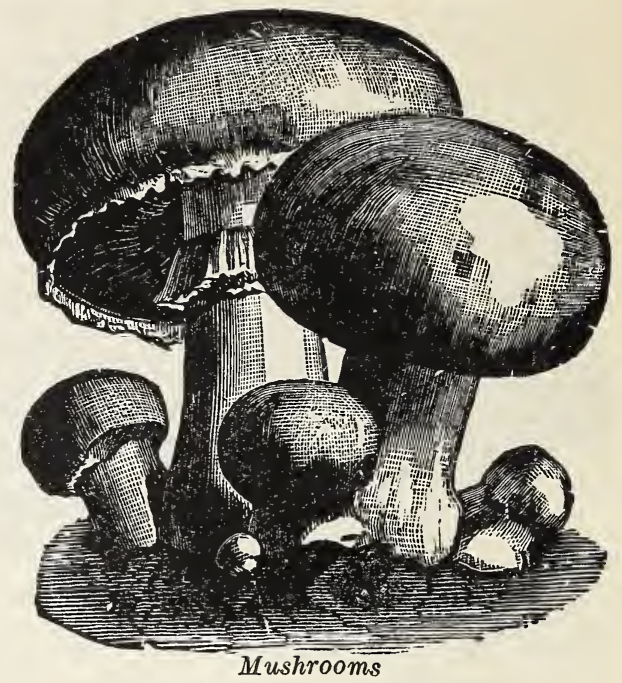

OKRA OR GUMBO

White Velvet. Young seed pods used for delicate "Gumibo" soups. Probably the finest vegetable. Easy to grow. Pkt. 10c; oz. 30c; $1 / 4$ lb. $\$ 1.00$.

\section{ONION SEEDS}

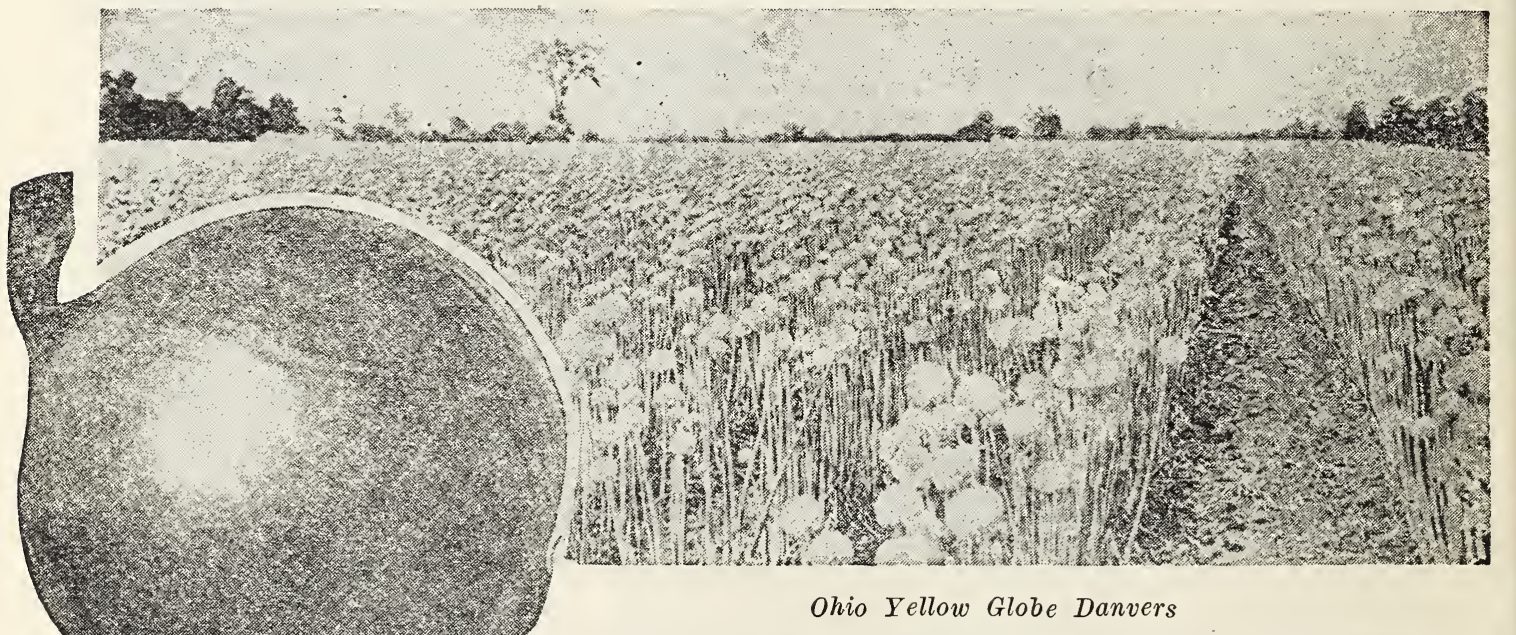

keeper, as it ripens up hard and firm; very fine grained, and of mild, delicate flavor. The outside skin is rich yellow while the flesh is white. Pkt. $10 \mathrm{c}$; 0z. $35 \mathrm{c} ; 1 / 4$ lb. $\$ 1.00$; lb. $\$ 3.25$.

Yellow Globe Danvers. Undoubtedly the best known and most popular of all onions; the earliest yellow variety; is entirely free from stiff necks. Globular in shape; has a small top. It is the most productive, producing as high as 1,000 bushels per acre, and will average on good soil, with proper culture, 700 or 800 bushels. Pkt. 10c; 0z. 25c; 1/4 lb. 80c; lb. $\$ 2.50$. By express, 10 lbs., $\$ 22.50$.

Prizetaker. Grows to an immense size and for fall marketing is unexcelled. Although of such great size, it is very hardy, and a fair winter

Large Red Wethersfield. Of large size, heavy yielder and most excellent keeper. Form round, somewhat flattened, skin deep purplish red; flesh purplish white, moderately fine grained and of stronger flavor than other kinds. Pkt. 10c; oz. 30c; $1 / 4$ lb. $80 \mathrm{c} ; 1 \mathrm{lb}$. $\$ 3.00$.

Mammoth Silver King. Of mammoth size, single bulbs often attain three or four pounds in weight. The skin is a beautiful white; the flesh is snowy white and particularly mild and pleasant flavor.

Pkt. 10c; 0z. 35c; $1 / 4$ lb. $\$ 1.00$; 1b. $\$ 3.50$. 
Southport Yellow Globe. Similar to the Danvers except larger in size, more like the Prizetaker. This is one of the most uniform growing varieties, every bulb being almost perfectly round and of the same size; light straw colored skin. Pkt. $10 \mathrm{c} ;$ oz. $30 \mathrm{c} ; \mathrm{r} / 4$ lb. $80 \mathrm{c} ; 1 \mathrm{lb} . \$ 2.50$; 10 lbs. $\$ 22.50$.

Southport White Globe. Pure white, of large size and globe shape. An immense yielder and good keeper. Pkt. 10 c; 0z. 30 c; $1 / 4$ lb. 80 c; lb. $\$ 2.50 ; 10$ lbs. $\$ 22.50$.

White Pickling. For pickling, early bunching or sets the finest strain offered. Private planters, market gardeners, pickle factories and others who once use it will have no other. Pkt. $10 \mathrm{c} ; 0 \mathrm{z} .30 \mathrm{c} ; 1 / 4$ lb. $\$ 1.00 ; 1 \mathrm{~b} . \$ 3.00$.

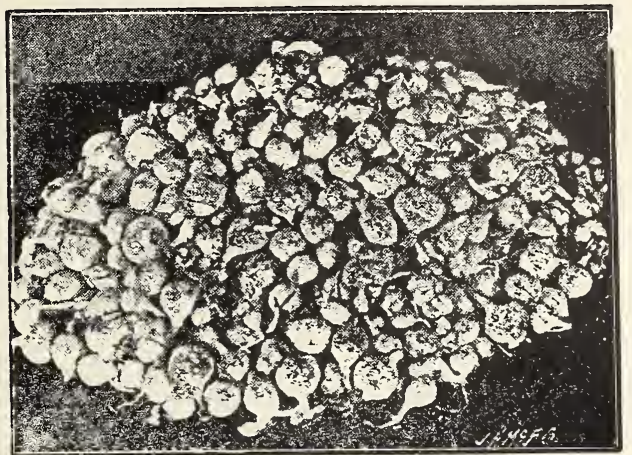

Bottom Onion Sets

\section{ONION SETS}

Yellow Onion Sets. Yellow onion sets from seed are best for early use and large onions. More used than any other kind. Per lb. 35c. By Express, $10 \mathrm{lbs}$. and over, 25c per lb.

White Bottom Sets. The best for early use and large onions. Per lb. 40c. By Express, $10 \mathrm{lbs}$. and over, 30c per lb.

Egyptian Brown. This can be used either green or for the winter. It develops into a very big onion. Per lb. 40c. By Express, 10 lbs. and over, 30c per lb.

\section{GARDEN PEAS (Wrinkled Seed)}

American Wonder. One of the earliest varieties; the very best of the wrinkled sorts. In productiveness, flavor and quality, they are unsurpassed. They are of a dwarf, robust habit, growing from 10 to 14 inches high. Pkt. 10c; lb. 45c; 2 lbs. 75c. By Express, 10 lbs., $\$ 2.50$.

Champion of England. A well known variety and acknowledged to be one of the best for late sowing. Pkt. 10c; lb. 45c; 2 lbs. 75c. By Express, 10 lbs., \$2.50.

Dwarf Telephone or Daisy (65 days). A medium late pea of dwarf, stock habit, healthy, vigorous growth, and productive, bearing large, handsome pods and peas of highest quality. Pkt. 10c; lb. $45 \mathrm{c} ; 2$ lbs. 80c. By Express, 10 lbs., $\$ 2.50$.

Horseford's Market Garden. A first class wrinkled pea; second early. Height 24 inches. Very productive. Pkt. 10c; lb. 40c; 2 lbs. 75c. By Express, 10 lbs., $\$ 2.50$.

Little Marvel. The vines average 15 inches in height, and the pods $2 \frac{1}{2}$ inches in length, frequently borne in pairs. The pods contain from 6 to 7 large dark green peas which remain in good eatable shape a week later than most other varieties. Pkt. 15c; lb. 50c; 2 lbs. 90c. By Express, 10 lbs., $\$ 3.00$.

Nott's Excelsior. Is fully as sweet and delicious as American Wonder and grows one-half taller. Pods are larger and it is far more productive than the Premium Gem, and as early as the first early smooth peas. Pkt. 10c; lb. 45c; 2 lbs. 75c. By Express, 10 lbs. \$2.50.

Telephone. Large, wrinkled sort; second early, an excellent pea. Pkt. 10c; lb. 45c; 2 lbs. 80c. By Express, 10 lbs., $\$ 2.50$.

\section{PEAS (Smooth Seed)}

Early Alaska. The Alaska is the earliest of all peas, is the most prolific good flavored of all the early peas. The Alaska is from two days to a week earlier than any other pea. A good pea for market gardeners. Pkt. 10c; 1b. 45c; 2 lbs. 75c. By Express, 10 lbs. $\$ 2.50$.

First and Best. Early, productive and hardy with a strong, vigorous vine, which is light in color and uniform in growth, $2 \frac{1}{2}$ to 3 feet in height and bearing straight pods $2 \frac{1}{2}$ to $23 / 4$ inches long, round, light in color and blunt at the ends. Is fit for table use 50 to 52 days from planting. Seed round, rather small, and white in color. Pkt. 10c; lb. 45c; 2 lbs. 80c. By Express, 10 lbs. $\$ 2.50$.

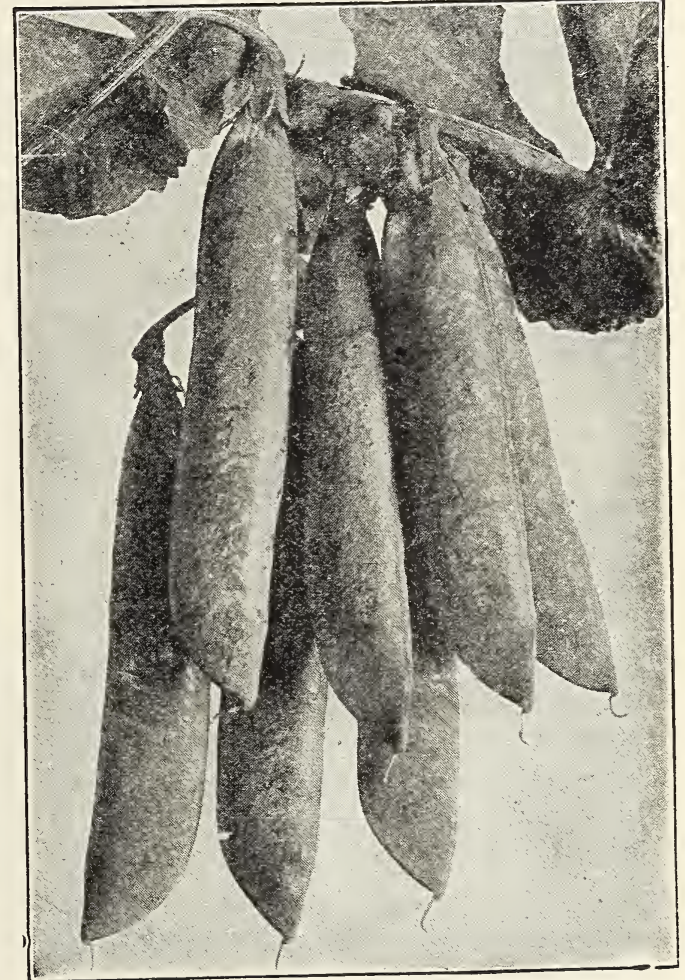

Little Marvel

\section{PEANUTS}

Virginia. This is the common peanut grown in the South. Peanuts can be raised with but little expense and are an exceedingly productive and paying crop. They are planted in much the same manner as potatoes, and require but little care beyond hilling up the young plants. Pkt. 10c: 1b. $40 \mathrm{c}$. 


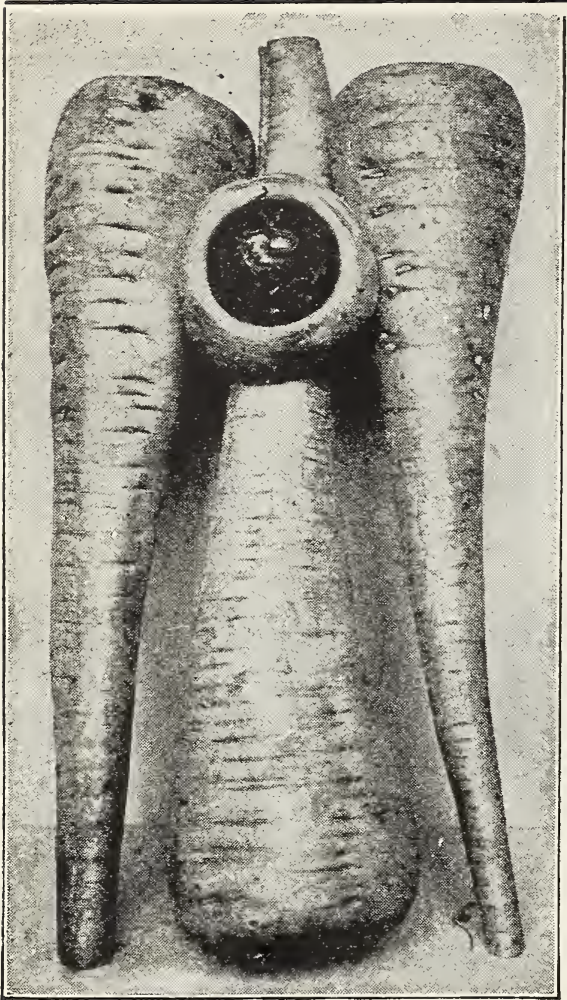

Parsnip

\section{PARSLEY}

Champion Moss Curled. This is a vigorous, compact growing variety, excellent for garnishing and flavoring, and a handsome decorative plant. Leaves very finely cut and so closely crisped or curled as to resemble bunches of moss. This is one of the most popular sorts for both the market and home garden. Pkt. 10c; oz. 25c.

Hamburg Rooted. The root is the edible portion of this variety and resembles a small parsnip, both in color and shape. Flesh white, a little dry and in flavor is similar to celeriac. The foliage is practically the same as that of Plain Parsley. Pkt. 10c; 0z. 25c; $1 / 4$ lb. 75c; $1 \mathrm{lb}$. $\$ 2.00 ; 5$ lbs. $\$ 8.00$.

\section{PARSNIP}

Hollow Crown. The roots are perfectly hardy and are improved in flavor by the action of the frost. Roots can be dug during thaws in winter or very early in spring, when a change of food is most relished. They are boiled whole, then sliced thin and fried brown with salt pork. While highly appreciated for the table, the great value of the parsnip for stock feeding is but little known. Pkt. 10c; oz. 20c; I/4 lb. $40 \mathrm{c} ; 1 \mathrm{~b} . \$ 1.25$.

\section{PEPPERS}

Chinese Giant. Undoubtedly the largest pepper in existence. Plant is of strong growth, and a very prolific bearer. Flesh is thick, of bright scarlet color; very mild and sweet. Pkt. $10 \mathrm{c}$; 0z. $75 \mathrm{c} ; 1 / 4$ lb. $\$ 2.00 ; 1$ lb. $\$ 6.50$.

Iarge Bell or Bull Nose. The best and most profitable mild red pepper for market or family use; so sweet and mild they can be eaten raw like an apple; largest size. Pkt. 10c; 0z. 75c; $1 / 4$ lb. $\$ 2.00 ; 1$ lb. $\$ 6.50$.

Long Red Cayenne. A well-known variety having a slender, twisted and pointed pod about 4 inches long, and when ripe, bright red in color. Extremely strong and pungent flesh. Pkt. $10 \mathrm{c} ;$ oz. $75 \mathrm{c} ; 1 / 4$ lb. $\$ 2.00 ; 1$ lb. $\$ 6.50$.

Ruby King. The most popular large-fruited pepper. Very prolific. The pods are a beautiful bright red, 5 to 6 inches long by 3 to 4 inches in diameter. Flesh exceedingly thick, sweet and so mild that it is often sliced as a salad. Splendid for stuffing as mangoes. Pkt. 10c; oz. 75c; $1 / 4$ lb. $\$ 2.00$; 1 lb. $\$ 6.50$.

Sweet Mountain or Mammoth. This pepper is in shape similar to Large Bell, but fruits are much larger and not nearly so pungent. A splendid sort for making stuffed pickle. Has been a standard large pepper for many years. Pkt. 10c; oz. $75 \mathrm{c} ; 1 / 4$ lb. $\$ 2.00$; 1 lb. $\$ 6.50$.

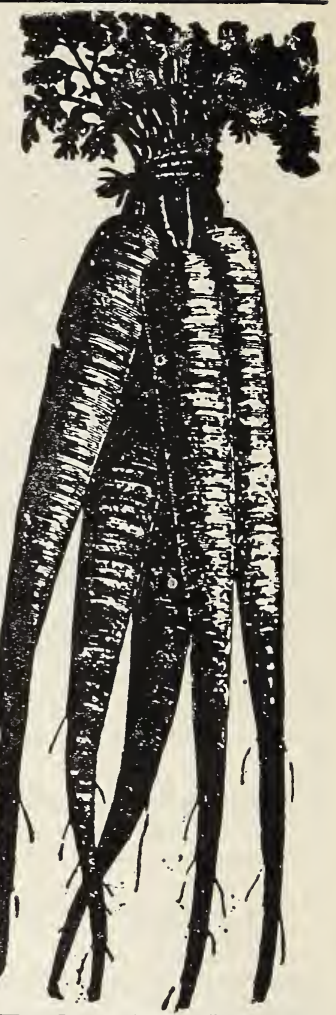

Hamburg Rooted Parsley

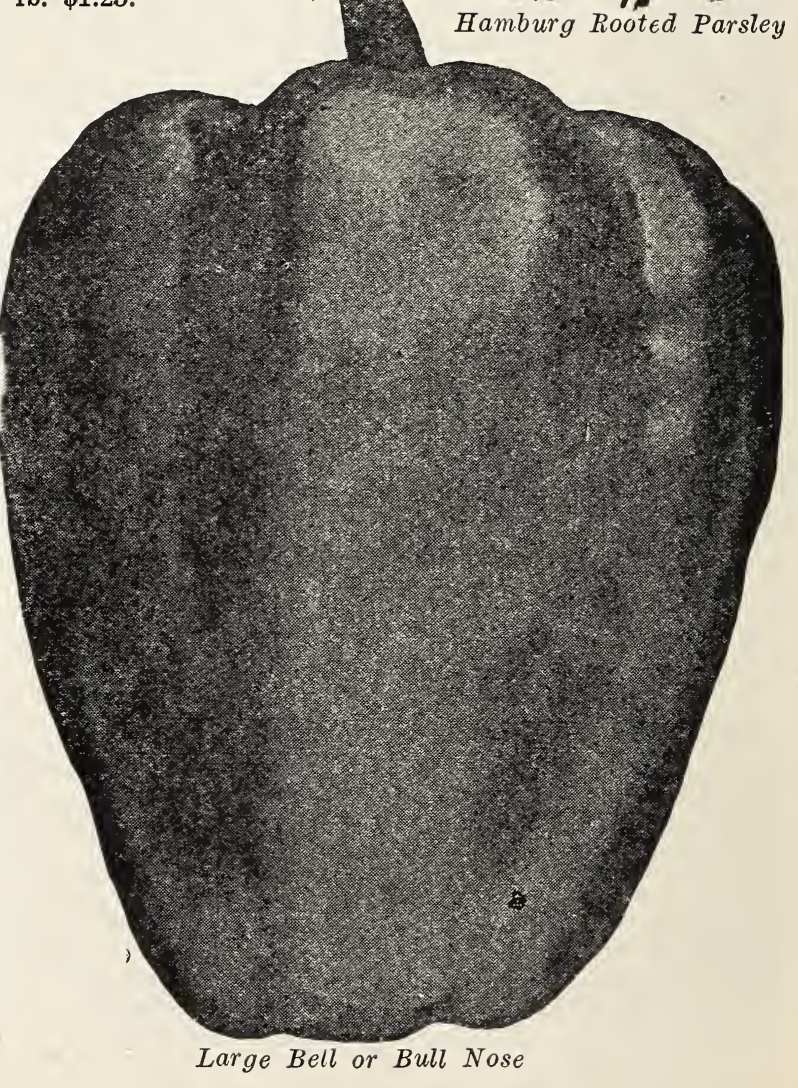




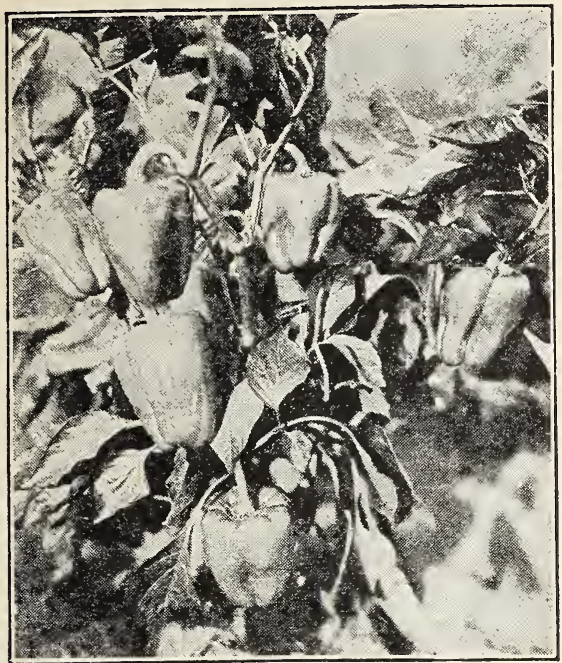

Yellow Giant

Yellow Giant. This variety is undoubtedly the largest yellow sweet pepper ever offered. The fru ts are golden yellow, the flesh is thick, remarkably sweet; without the least trace of fieryness. It is an excellent variety for home and market, producing the attractive and large fruits with astonishing freedom. Pkt. 15c; oz. \$1.00; $1 / 4$ lb. $\$ 2.50 ; 1$ lb. $\$ 8.00$.

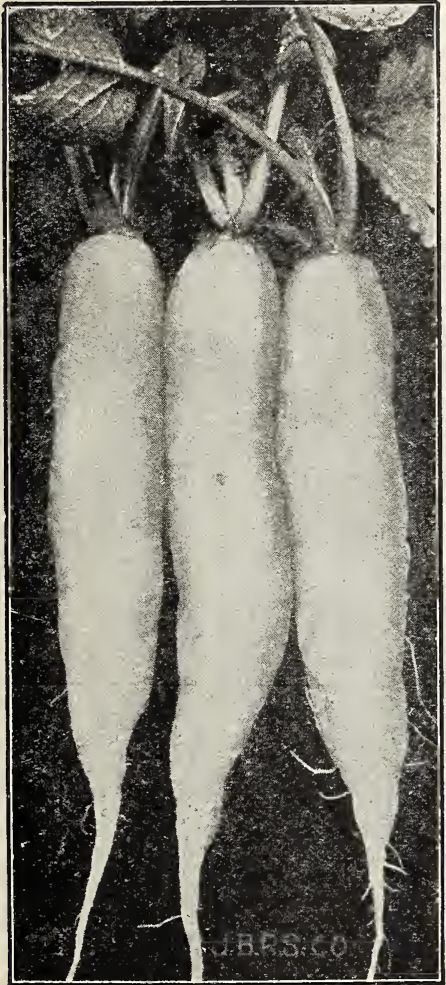

Icicle

\section{PUMPKIN}

Go'den Qunen. New, very large. They are very productive, growing from 12 to 20 perfect fruits 7 to 8 inches long on a single plant. In color they are a bright, waxy, golden yeliow, and mild in flavor. Pkt. $10 \mathrm{c} ;$ oz. $15 \mathrm{c} ; 1 / 4$ lb. 50c; lb. $\$ 1.75$.

Green Striped Cushaw. (75 days.) Th:s is one of the finest pumpkins in existence; a long crooked neck, terminating in a round or oblong end, enclosing a very small seed cavity : flesh surrounding seed cavity very thick. The neck is absolutely solid, rivaling the finest sweet potatoes for bakng, or as a pie sort, it has no equal. Pkt. 10c; 0z. 25c; $1 / 4$ lb. $75 \mathrm{c}$.

King of the Mammoths. This is truly a giant among Pumpkins: specimens have been grown to weigh 250 pounds. In shape it is round flat, and slightly ribbed; color of skin and flesh bright golden principally, and of good quality, making excellent pies, but grown principally for stock; keeps well. Pkt. 10c; oz. 25c; $1 / 1$ lb. $75 \mathrm{c} ; 1 \mathrm{lb}$. $\$ 2.00$.

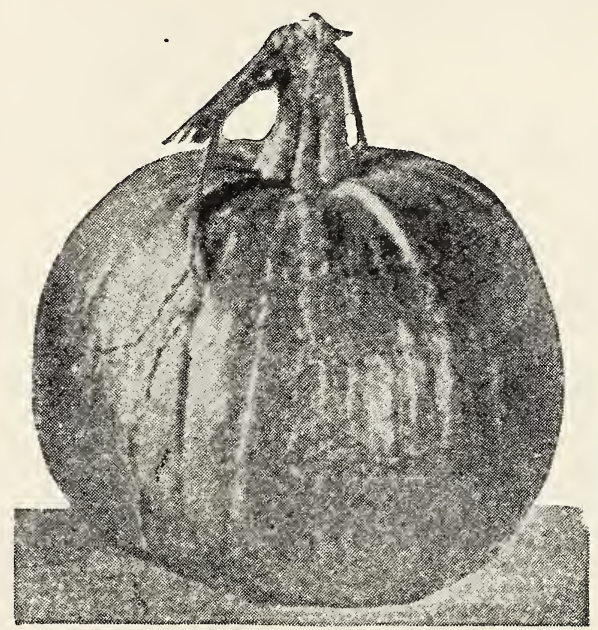

L a r g e Yellow. Large, yellow, very productive, grown for stock, very good $f \circ r$ pies. If p lan t e d with corn it only requ ires 2 lbs. of good s e e d per acre. Pkt. $10 \mathrm{c}$; $\mathrm{Oz}$. 25c; $1 / 4$ lb. 45c; 1 lb. $\$ 1.50$.

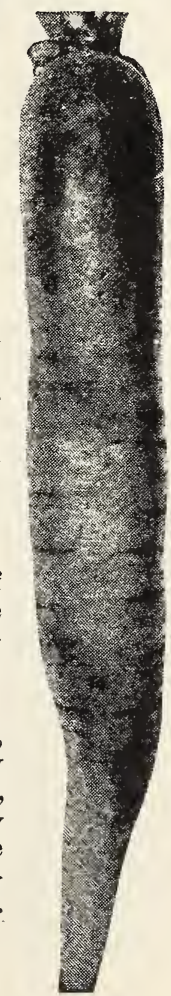

Blue. Used for the table. Pkt. $5 \mathrm{c} ; 0 \mathrm{z} .10 \mathrm{c} ; 1 / 4 \mathrm{lb}$. 20c; 1b. 40c. By Express, $5 \mathrm{lbs}$. or over, 35c lb.

\section{RADISH}

Cincinnati Market. A desirable market variety with roots similar to Early Long Scarlet, Short Top, Improved, but averaging longer, deeper red in color and remaining a little longer in condition for use. The roots are slender and before becoming pithy are often six to seven inches long by about five-eighths of an inch in diameter at the shoulder. Pkt. 10c; 0z. 20c;

Crimson Giant. Color crimson, flesh pure white, of the best quality. Fine for outdoors and forcing. The seed should be sown very thinly to permit full development of the roots. Pkt. $10 \mathrm{c} ; 0 \mathrm{z} .20 \mathrm{c} ; 1 / 4 \mathrm{lb} .50 \mathrm{c}$;

Icicle. The best long, white radish. Very early, with long, slender, pure white roots. The roots grow about 4 inches long, are of transparent whiteness, brittle, crisp, and of mild flavor; tops very small. 'They will keep crisp and fresh for a long time. May be planted throughout the season for first early, for sum. mer and for late use. Quality is always good. Pkt. $1 / 4$ lb. $50 \mathrm{c}$; $1 \mathrm{~b}$. $\$ 1.25$. lb. $\$ 1.75$. 10 c; oz. 20 c; $1 / 4$ lb. 50 c; lb. $\$ 1.25$. 


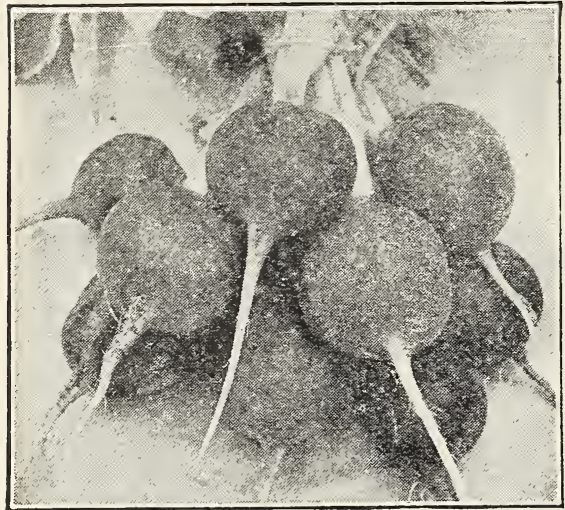

Round Black Spanish
Early Scarlet Globe. It is the earliest; in color it is the handsomest; in flavor it is the mildest, crisp, mos t juicy and tender. It forms small top and will s t a n d a great amount of heat without becoming pith y; is equally as good for early outdoor planting. Pkt. 10c; oz. 20c; $1 / 4$ lb. 50 ; lb. $\$ 1.25$.

Sluis Sparkler. An excellent strain of old Scarlet Turnip white Tip. Small round roots with bright scarlet top, and small slender taproot. The juicy flesh is pure white, and of agreeable snappy flavor. Sluis Sparkler is popular with many market growers and home gardeners who seek a choice radish for an early supply. Our strain which we have imported from Holland is particularly fine. Pkt. 10c; oz. 20c; $1 / 4$ lb. 50c; lb. $\$ 1.25$.

\section{WINTER RADISHES}

California Mammoth White. Pure white, about 1 foot long and 2 or 3 inches through. Flesh tender and crisp. Pkt. 10c; oz. 20c; $1 / 4$ lb. 50c; lb. $\$ 1.25$.

China Rose Winter. A bright rose colored variety. The most popular of the winter radishes because of its bright color, firm and long-keeping qualities. Pkt. $10 \mathrm{c}$; oz. 20c; $1 / 4$ lb. 50c; lb. $\$ 1.50$.

Round Black Spanish. In a good many markets the round radish is preferred to the long, and for such markets the Round Black Spanish should be grown. This variety is similar to the Long Black Spanish excepting in the shape, and is considered one of the finest sorts for winter use. Pkt. 10c; oz. $25 \mathrm{c}$; $1 / 4$ lb. $50 \mathrm{c}$; lb. $\$ 1.50$.

\section{RHUBARD or PIE PLANT}

Linnaeus. Large and tender; the very finest of all. Pkt. 10c; oz. 20c; $1 / 4$ lb. 60c; lb. $\$ 1.75$.

\section{SORREL}

Large Leaved French. The best garden variety of Sorrel, when well grown and cooked like spinach, makes a palatable dish. Sow in drills early in spring and thin the seedlings to six to eight inches apart in the row. Pkt. $10 \mathrm{c}$; oz. 50c; $1 / 4$ lb. $\$ 2.00$.

\section{SPINACH}

King of Denmark (Antvorskov). The best longseason spinach, remaining two weeks longer than others before bolting to seed. Plant vigorous and spreading; leaves large, rounded, crumpled and blistered deep green in color. Bids fair to replace all others for spring planting. Pkt. 15c; oz. 20c; $1 / 4 \mathrm{lb}$. $35 c$; 1 lb. $\$ 1.00$.

Round Thick Leaved. A strong growing and early maturing sort, with very large, thick leaves of fine, deep green color. One of the most desirable, medium early sorts for home gardeners as well as truckers. Pkt. 10c; oz. 20c; $1 / 4$ lb. 50c; lb. $\$ 1.50$.

New Zealand. This sort is grown to supply the place of the ordinary spinach during the hottest months of the year or in dry, arid places, where the ordinary spinach does badly. The plant is very large, with thick, fleshy leaves of very fine flavor and remains crisp and tender from early summer until cut by frost. Pkt. 10c; oz. 20c; $1 / 4$ lb. 35c; 1 lb. $\$ 1.00$.

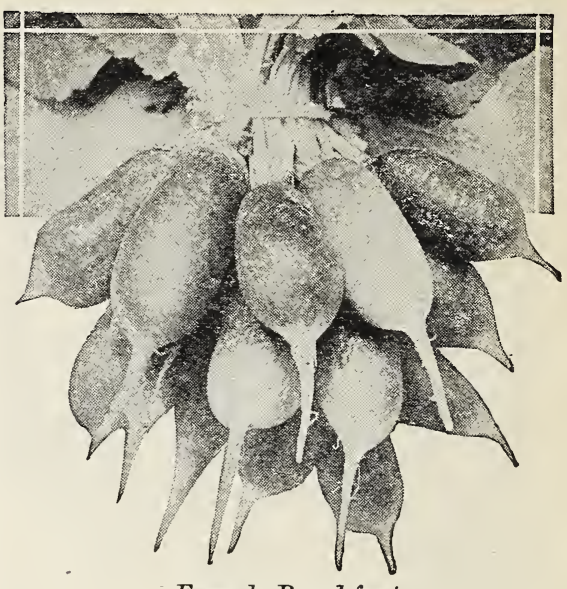

French Breakfast

French Breakfast. A quick growing, small, olive-shaped radish about 2 inches long when fully grown. Color, beautiful deep scarlet except a little clear white about the tip. Its small top and earliness makes it very desirable for growing under glass as well as for planting outdoors. Splendid for the table on account of its excellent quality and attractive color. Pkt. 10c; oz. 20c; $1 / 4$ lb.. 50c; lb. $\$ 1.50$.

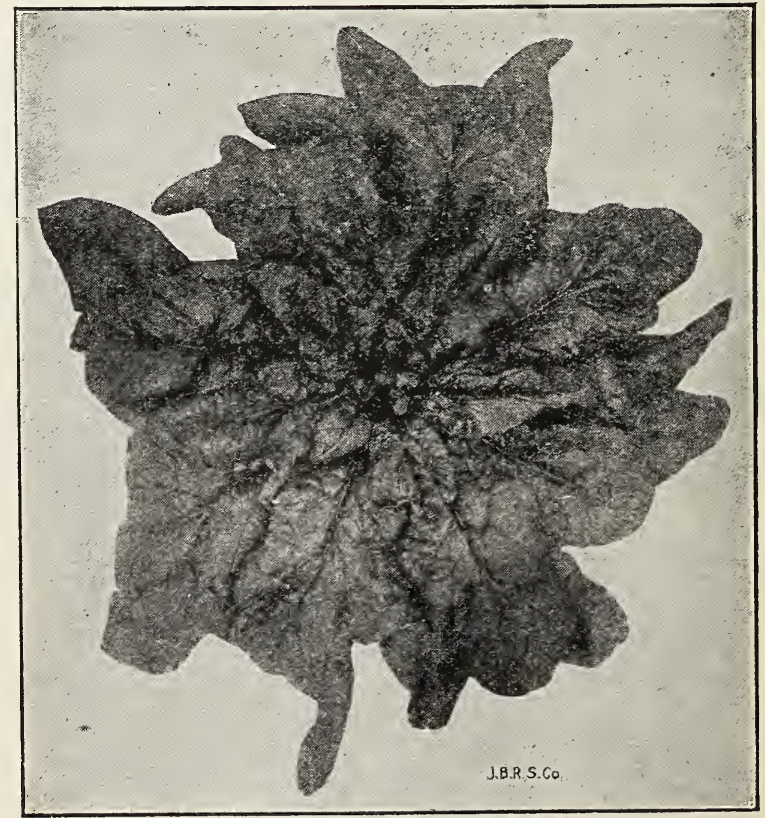

King of Denmark 


\section{SUN FLOWER}

Mammoth Russian. This is the large-flowering variety used principally by farmers and poultry breeder. Pkt. 10c; $1 / 4$ lb. 20c; 1 lb. 30c.

\section{SQUASH-SUMMER VARIETIES}

Cocozelle Bush. An early squash. If picked as soon as matured, it will continue to bear until killed by frost. Its habit of growth is the same as the ordinary Summer Squash, requires the same kind of soil and tillage and begins to bear early. It is used in the green state and is better than Egg Plant when nicely fried in butter and well seasoned. Pkt. 10c; oz. 35c; $1 / 4$ lb. 75c; 1 lb. $\$ 2.25$.

Early White Bush. This is the well known White Pattypan Squash. The earliest to mature, very productive, light cream colored. Pkt. 10c; oz. 35 c; $1 / 4$ lb. 75 ; lb. $\$ 2.25$.

Golden Summer Crookneck. Largest and one of the earliest of the crookneck summer squashes. Pkt. $10 \mathrm{c} ; 0 \mathrm{z}$. $35 \mathrm{c} ; 1 / 4 \mathrm{lb}$. $70 \mathrm{c} ; 1 \mathrm{lb}$. $\$ 2.25$.

Vegetable Marrow. The most desirable sort, fruits being of handsome shape, creamy white color, very large size, of excellent flavor. Very productive. Pkt. $10 \mathrm{c} ;$ oz. $35 \mathrm{c} ; 1 / 4 \mathrm{lb}$. $75 \mathrm{c} ; 1 \mathrm{lb} . \$ 2.25$.

\section{WINTER VARIETIES}

Delicious. Farly and very prolific; of oblong shape. Ground color orange-yellow, splashed and striped with very deep green. Although of small size, the squashes are very solid and heavy, while the quality is rich and dry. An excellent "all season" squash. Pkt. 10c; oz. 25c; $1 / 4$ lb. $75 \mathrm{c} ; 1$ lb. $\$ 2.25$.

Golden Hubbard. Vine vigorous and very productive. Fruits of medium size, weighing from six to eight pounds and in shape like the Hubbard, although in condition for use earlier. They are wonderfully long, keep, and can be held over in good condition for spring. Flesh, deep orange; dry, fine grained and richly flavored. Pkt. 10c; oz. 25c; $1 / 4$ lb. $75 \mathrm{c} ; \mathrm{i}$ lb. $\$ 2.25$.

True Hubbard. A general favorite; is more largely grown for winter use than any other variety; dry and excellent flavor. Our stock is true and fine. Pkt. 10c; oz. 25c; 1/4 lb. 75c; 1 lb. $\$ 2.50$.

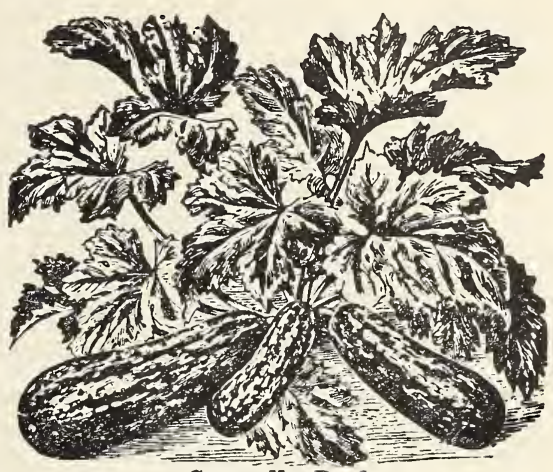

Cocozelle Bush

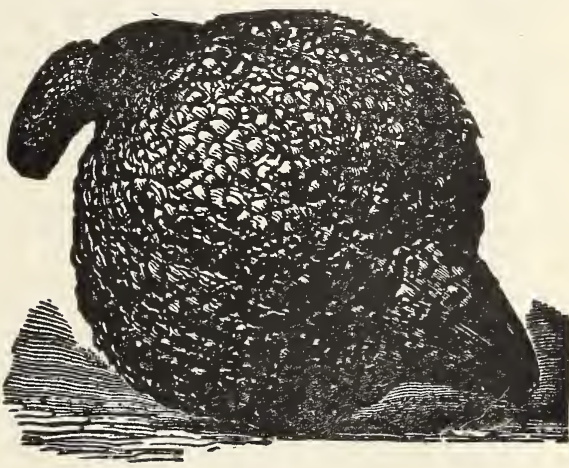

Golden Hubbard

\section{TOMATO}

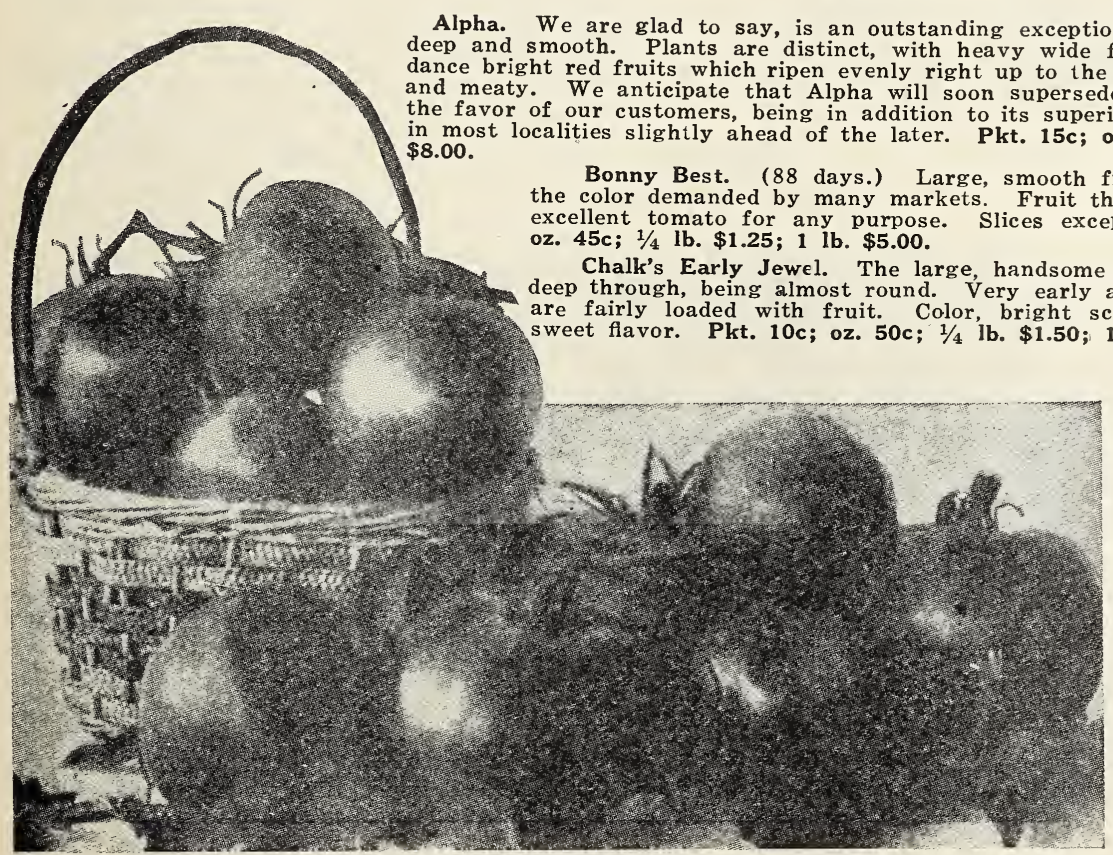

Alpha. We are glad to say, is an outstanding exception, the fruits coming very deep and smooth. Plants are distinct, with heavy wide foliage, and bear in abundance bright red fruits which ripen evenly right up to the stem, and which are solid We anticipate that Alpha will soon supersede the Earliana strains for the favor of our customers, being in addition to its superior type, ready for picking in most localities slightly ahead of the later. Pkt. 15c; oz. 75c; $1 / 4 \mathrm{lb}$. $\$ 2.50 ; 1 \mathrm{lb}$.

Bonny Best. ( 88 days.) Large, smooth fruit of a rich scarlet red, ( Slices exceptionally well. Pkt. 10c;

Chalk's Early Jewel. The large, handsome fruits are very solid and 作 are fairly loaded with fruit. Color, bright scarlet, very solid, of fine, sweet flavor. Pkt. 10c; oz. 50c; $1 / 4$ lb. $\$ 1.50 ; 1$ lb. $\$ 5.00$. Dwarf Champion.
Vine dwarf but vigor-
ous and productive.
While maturing with
the later sorts the
bright red fruits are of
color, $\mathrm{x}$ e d ng ly
smooth and very solid.
We consider this the
best of the large fruited
dwarf tomatoes. Pkt.
10c; oz. 45c; 1/4 lb. $\$ 1.25 ; 1$ lb. $\$ 4.50$.

Golden Q u e e n. (Bright yellow.) Best large yellow tomato. Always smooth and ripens early. Quality excellent in all respects, either for slicing or preserving. Queen of all the yellow. Pkt. $10 \mathrm{c}$; oz. 50c. 
June Pink. An extra early, purplish-pink tomato, similar to the popular scarlet fruited Earliana in growth of vine, shape and size of fruits and time of maturing. This is a variety of exceptional value to market gardeners, who want an early, purplish-pink tomato, either for home market or to ship; also desirable for planting under glass. Pkt. 10 ; oz. 45 c; $1 / 4$ lb. $\$ 1.25 ; 1$ lb. $\$ 4.50$.

Ponderosa. (110 days.) In addition to its ponderous size, it is also very solid, there being but few seeds. In color it is a beautiful crimson throughout. Pkt. $10 \mathrm{c}$; oz. $45 \mathrm{c} ; 1 / 4$ lb. $\$ 1.25 ; 1$ lb. $\$ 4.50$.

Stone. One of the best standard sorts. Color bright red. Fruits large size, perfectly smooth and of best table quality. A famous main crop tomato in many sections and is much used for canning. Pkt. $10 \mathrm{c}$; oz. $45 \mathrm{c}$; $1 / 4$ lb. $\$ 1.25 ; 1$ lb. $\$ 4.50$.

\section{TOBACCO}

Connecticut Seed Leaf. One of the oldest and best varieties. Pkt. 10c; oz. 50c.

Havana. The best known variety, as it brings highest market price when well grown and cured. Plkt. 10c; oz. 60c.

\section{TURNIP}

Early White Flat Dutch. A most excellent early variety. Roots medium size, flat; color, white; very early, sweet and tender. Pkt. 10c; oz. 20c; $1 / 4$ lb. 40 c; 1 lb. $\$ 1.25$.

Early Snowball. A globe-shaped, white-skinned turnip, very fine grained, firm and of delicatê flavor. One of the best-keeping of white-fleshed sorts, very early and particularly adapted for family or market use. Pkt. 10c; oz. 20c; 1/4 lb. 40c; 1 lb. $\$ 1.25$.

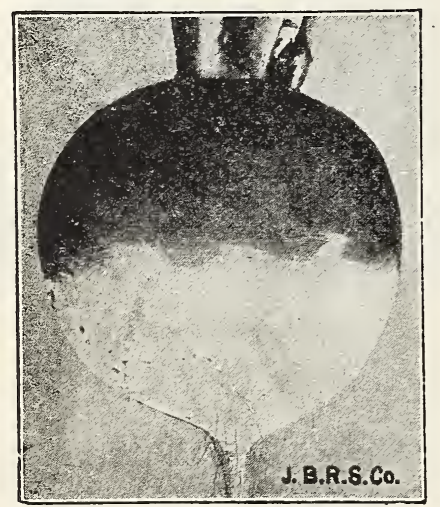

Purple Top White Globe

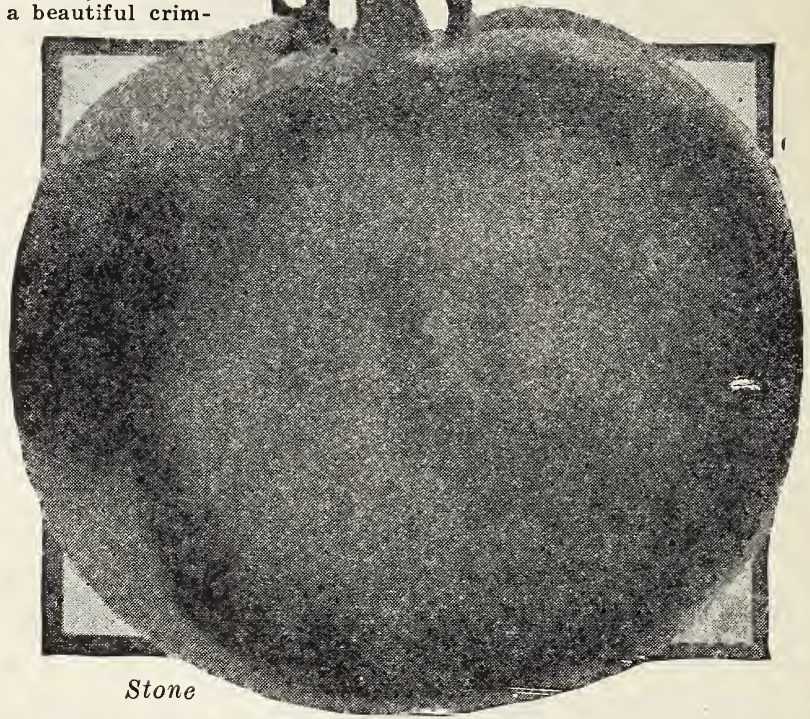

Purple Top Strap Leaf. It is one of the best turnips on the market for both table and stock feeding. Has a bright purple top, white underneath. Leaves are short narrow and erect. Pkt. 10c; oz. 20c; $1 / 4$ lb. $40 \mathrm{c} ; 1$ lb. $\$ 1.25$

Purple-Top White Globe. The root is nearly round and only slightly flattened at the top. The purplish color extends well down the sides of the root. Pkt. 10c; oz. 20c; $1 / 4$ lb. 35c; lb. $\$ 1.25$.

\section{RUTA-BAGAS \\ SWEDISH TURNIP}

Imported American Yellow Purple-Top. An excellent yellow variety for either stock or table. Pkt. 10c; oz. 20c; $1 / 4$ lb. 40 c; 1 lb. $\$ 1.25$.

White Sweet German. This variety is a most excellent kind, grows to large size; very fine for stock or table. Pkt. 10c; oz. 20c; $1 / 4$ lb. 40 ; 1 lb. $\$ 1.25$.

\section{HERBS}

SWEET, MEDICINAI

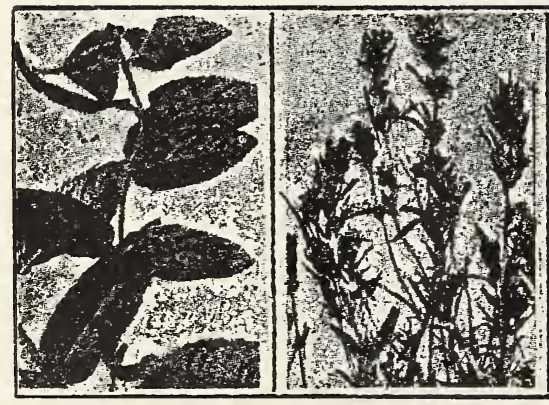

Savory
Thyme

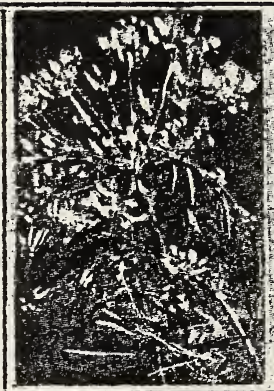

Dill

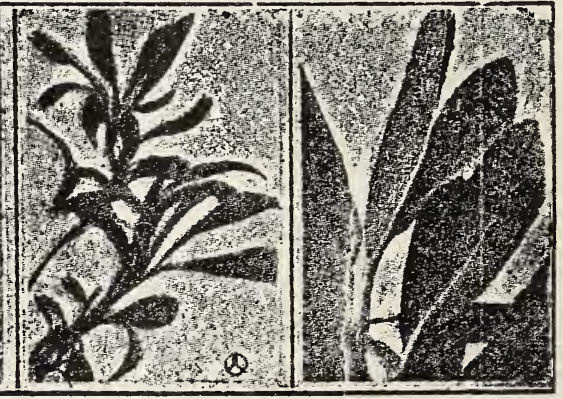

Lavender
Sage
Sweet Marjoram

\section{Savory, Summer}

Thyme

Rosemary

Safiron pkt. 10c

pkt. $10 \mathrm{c}$

pkt. $10 \mathrm{c}$

pkt. $10 \mathrm{c}$

pist $10 \mathrm{c}$
Sage-Broad Leaf pkt. $10 \mathrm{c}$ Lavender _........ 10c Caraway Dill _..... 10c Basil _. 


\section{FARM SEED SEED BARLEY}

Beardless Barley. Earliest barley known. The straw is abrut the height of common barley, but better, and will stand up on any land. This is beardless and as easy to grow and handle as oats, and is a heavy cropper, yielding from 50 to 75 bushels per acre, quality excellent. 1 bu. $\$ 3.00 ; 10 \mathrm{bu}$. $\$ 28.00$.

Bearded Barley. A six-rowed barley, well known and popular. The standard market variety by which all are graded and therefore the most popular bearded sort. It is an early variety, very strong, stiff straw, stands up and stools well. It bears large, well-filled heads of plump-berried grain. 1 bu. $\$ 3.00 ; 10$ bu. $\$ 28.00$.

\section{SEED CORN}

New Leaming Corn. With almost every desirable characteristic, has a combined commerial and agricultural value of incalculable worth. It is today one of the most popular types in the great corn belts. One of the best all around heavy yielding Dent Corns of the country, known the world over as a heavy yellow corn. Has yielded 1,238 bushels on 10 acres. Ears 10 inches long; 18 to 20 rows, well filled with wedge shaped, reddish yellow kernels of medium size. Ripens in about 95 to 100 days. Ib. 25c; 2 lbs. 40c. By Express, $1 / 4$ bu. $\$ 1.25$, 1 bu. $\$ 4.00$.

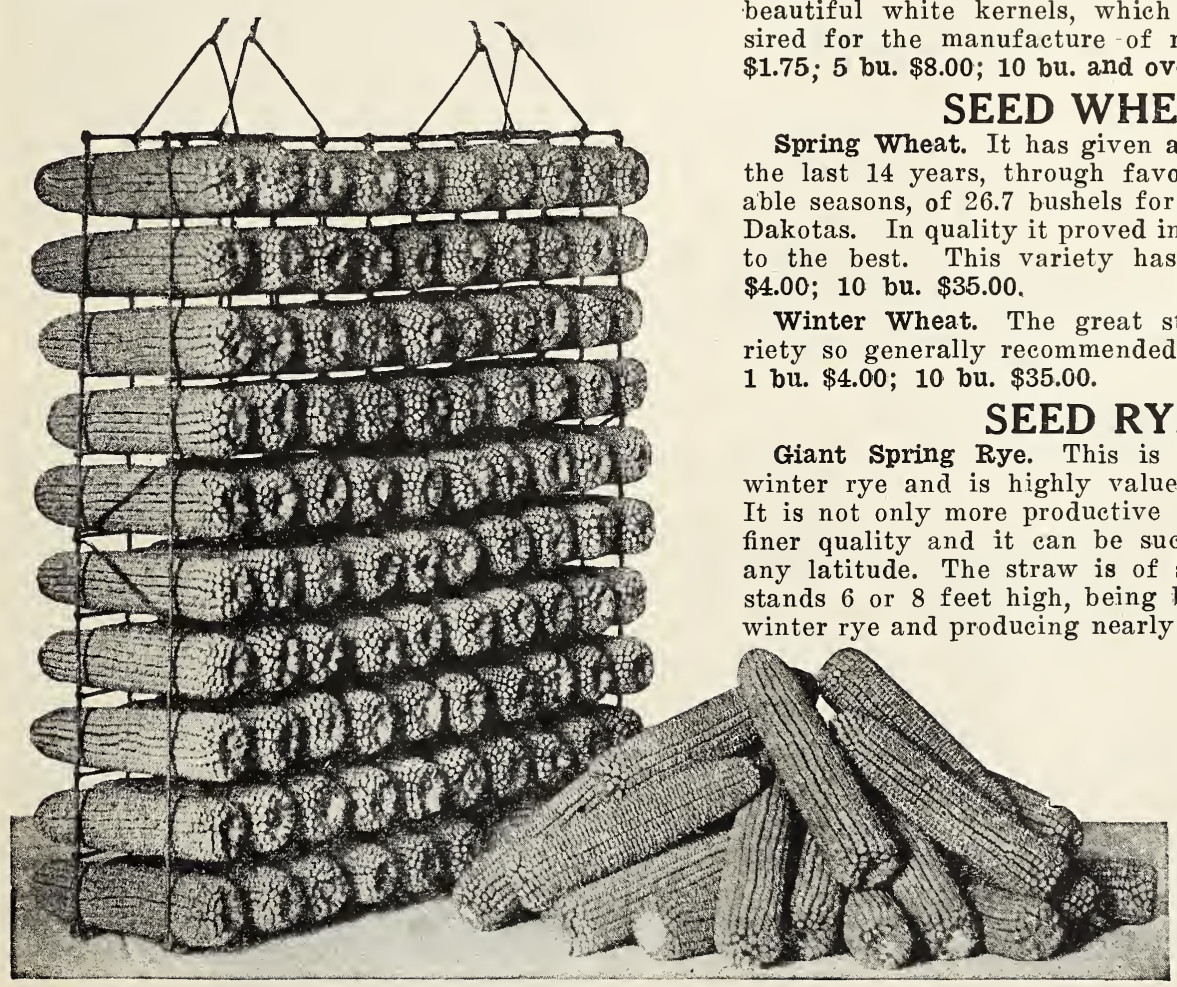

New Leaming Corn
Iowa Silver Mine. Now recognized as the best standard and most reliable 110-day White Dent Corn in cultivation. Extremely hardy, very prolific, large deep grain, small cob, producing average yield 15 to 100 bushels per acre. Ib. 25c.; 2 Ibs. 40c. By Express, $1 / 4$ bu. $\$ 1.25 ; 1$ bu. $\$ 4.00$.

Pride of the North. A yellow Dent variety, maturing in 90 days. Ears 8 to 10 inches long, 16 rows on the ear, cob small, grain above medium size and closely set. One of the hardiest, and especially adapted to the northern planter; will mature farther north than any other Dent corn. Ib. 25c; 2 lbs. 40c. By Express, $1 / 4$ bu., $\$ 1.25 ; 1$ bu. $\$ 4.00$.

White Cap Yellow Dent. A very strong grower with heavy fodder and large ears. Matures in 90 days. The grain has white cap, yellow body. Heavy yielder. Lb. 25c; 2 Lbs. 40c. By Express, 1/4 bu. $\$ 1.25 ; 1$ bu. $\$ 4.00$.

Sweet Fodder Corn. This is of greater value for dairy farmers than common fodder corn on account of its high feeding and milk producing quality. As a green fodder for cutting in the summer, one acre is worth eight acres of ordinary pasture. Sow in drills or broadcast two bushels per acre. Ib. $25 \mathrm{c} ; 2$ lbs. 40 c. By Express $1 / 4$ bu. $\$ 1.25 ; 1$ bu. $\$ 4.00$.

\section{SEED OATS}

Swedish Select Oats. Will yield from 80 to 115 bushels to the acre; are not liable to rust. Straw stands up well. Large long heads. Heavy plump meat of grain. This oat has made for itself a reputation as an extraordinary heavy and reliable yielder. It is very hardy and prolific and yields beautiful white kernels, which are especially desired for the manufacture of rolled oats. 1 bu. $\$ 1.75 ; 5$ bu. $\$ 8.00 ; 10$ bu. and over, $\$ 1.50$ per bushel.

\section{SEED WHEAT}

given an average yield for for Minnesota and the so beards. 1 bu. .00; 10 bu. $\$ 35.00$. riety so generally recommended by all authorities.

\section{SEED RYE} th highly valued wherever grown. ive but the grain is of be successfully grown in is of special value, as it stands 6 or 8 feet high, being better than that of winter rye and producing nearly four times as much straw as oats. Produces 30 to 40 bushels of $\mathrm{g} r$ a $\mathrm{i} n$ to the acre. As it does not stool like winter rye, not less than two bushels to the acre should be sown. Ib. 35c. By Express 1 bu. $\$ 2.50$; 10 bu. $\$ 22.50$. 


\section{CLOVER}

Alfalfa or Lucerne. (Mediago Sativa). One of the best varieties, succeeding in almost every situation and bearing heavy crops of forage. Will bear cutting three or four times during the season. Lb. 50c; 3 lbs. $\$ 1.40$. By Express, 5 lbs. and over, $40 c$ per $1 b$.

Alsike or Swedish Clover. This is one of the hardiest varieties known. It is perennial and does not winter kill. It will do better on moist land than any other variety of clover, and is suitable for either hay or pasture. It is frequently sown with both Medium Red Clover and Timothy and the quality of hay thus produced is excellent. Lb. 50c; 3 lbs. \$1.40. By Express, 5 lbs. and over, $40 \mathrm{c}$ per lb.

Crimson or Scarlet Clover (Trifolium Incarnatum). The only clover that yields a heavy full crop the first season. It grows about 2 feet high. Will grow on nearly all soils and succeeds well on sandy soil.

There is hardly a better crop than Crimson Clover for cutting green. It makes excellent feed for milch cows and all kinds of stock. It makes superior hay and is of great value as fertilizer. Lb. 40c; 3 lbs. $\$ 1.00$. By Express, 5 lbs. and over, 30c per lb.

\section{MEDIUM RED CLOVER}

This is regarded as the most valuable of the Clover family. It is sometimes called June Clover and is a dependable allround variety for farmers and stockmen. It makes two crops each year. The first is usually cut when it is in blossom for hay; the last crop may be harvested for seed. cut for hay, or plowed under to add fertility to the soil. Lb. 50c; 3 lbs. $\$ 1.40$. By Express, 5 lbs. and over, $40 \mathrm{c}$ per lb.

\section{WHITE DUTCH CLOVER}

Excellent for lawns in mixtures with grasses. A good pasture clover. Sow at the rate of 6 to 8 pounds per acre. Lb. $80 \mathrm{c} ; 3 \mathrm{lbs}$. $\$ 2.00$. By Express, $5 \mathrm{lbs}$. and over, $60 \mathrm{c}$ per lb.

\section{SWEET CLOVER}

(Bokhara.) (Meliotus alba.) This legume is native to all parts of this country and is the most beneficial of all crops for building up worn-out land. Thrives on all soils, but like all clovers, requires lime, which should be supplied on land where it is lacking. Lb. 50c; 3 lbs. \$1.40. By Express, 5 lbs. and over, $40 \mathrm{c}$ per $\mathbf{l b}$.

\section{HUBAM CLOVER}

\section{Annual White Blossom Sweet Clover, a Valuable Forage Plant}

It is an annual plant discovered by Professor Hughes of Iowa. It will grow almost anywhere. Hubam has an important place among the leguminous crops of the United States. When sown on Fall Wheat and with Rye, Oats, or Barley; used as a nurse crop with clovers or seeded alone, it affords an excellent fall pasture or a hay crop equal in feeding value to alfalfa. It is a wonderful soil builder, being unrivaled as a green manure for plowing under. Lb. $60 \mathrm{c} ; 3$ lbs. $\$ 1.60$. By Express, 5 lbs. and over, $50 \mathrm{c}$ per $\mathbf{l b}$.

\section{MISCELLANEOUS FARM SEEDS}

Broom Corn. The best variety for general cultivation on account of color and quality of brush. Ripen early. Grows about 8 to 10 feet high. Brush good length, fine and straight. Lb. 40c; 3 lbs. \$1.00. By Express, 5 lbs. and over, 20c per lb.

Millet, Golden or German. German Millet is very sweet, palatable, and when fed to dairy cows produces a large amount of milk. On good, rich soil it grows 4 to 5 feet high. It is very tender if cut at the right stage, which is when it is in full bloom. About three-fourths of a bushel of seed is sown to the acre. A good yield is from three to five tons of hay to the acre. Lb. 35c. By Express, $10 \mathrm{lbs}$. and over, 10c per lb.

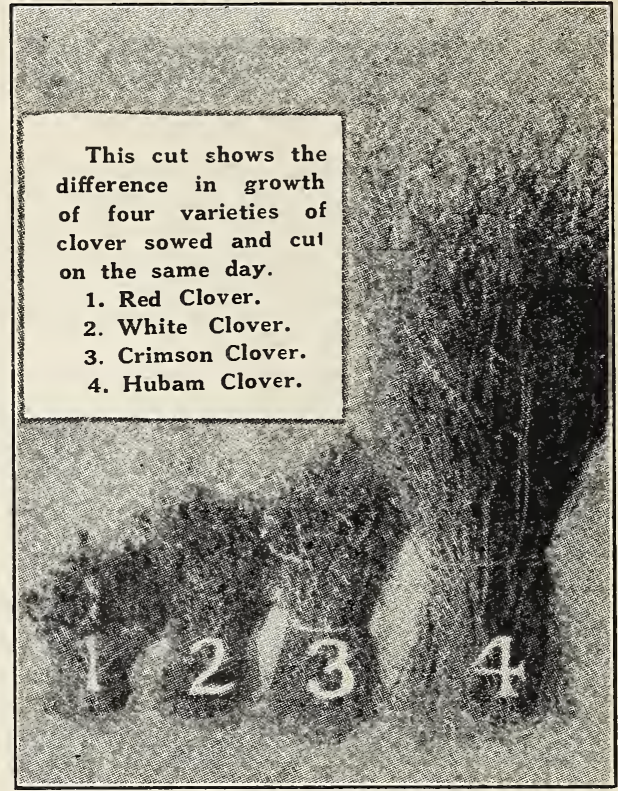

Hubam Clover

Spring Vetch. This Vetch (Vicia Sativa) is not hardy and must therefore be sown in the spring during May or June. It possesses the same desirable fea ures as the Winter Vetch. Use $1 \frac{1 / 4}{4}$ bushels per acre alone, if with spring wheat, spring rye or oats for support. Lb. $30 \mathrm{c} ; 3 \mathrm{lbs} .80 \mathrm{c}$. By Express, 5 lbs. and over, $15 \mathrm{c}$ per lb. (60 lbs. in bushel.)

Sand, Hairy or Winter Vetch. (Vicia Villosa.) Succeeds and produces as good crops on poor, sandy soils as on good land; grows to a height of 4 or 5 feet. It is perfectly hardy throughout the United States, remaining green all winter; should be sown in the spring, mixed with oats, spring rye or barley; or during August or September with winter rye. which serves as a support for the piants. Lb. $40 c ; 5$ lbs. $\$ 1.75$. By Express, 10 lbs. and over, 20c per lb.

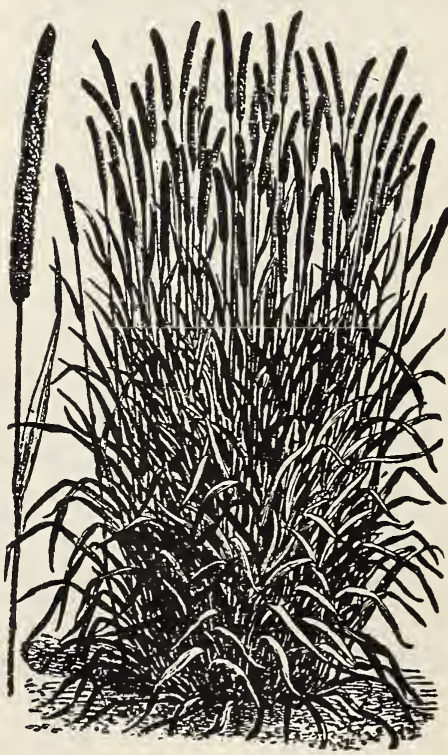

Tim ot hy. ( $P$ h l e u m Prat e n se.) Good seed is important for high yields and cle a $\mathrm{n}$ fields. 0 u r seed has never b e e $n$ cleaner than the new, fresh crop that we offer this y e a r. Seed that any farmer would be proud to sow. Lb. 30c; 3 lbs. 70c. By Express, 10 ths. and over, 12c per lb. 


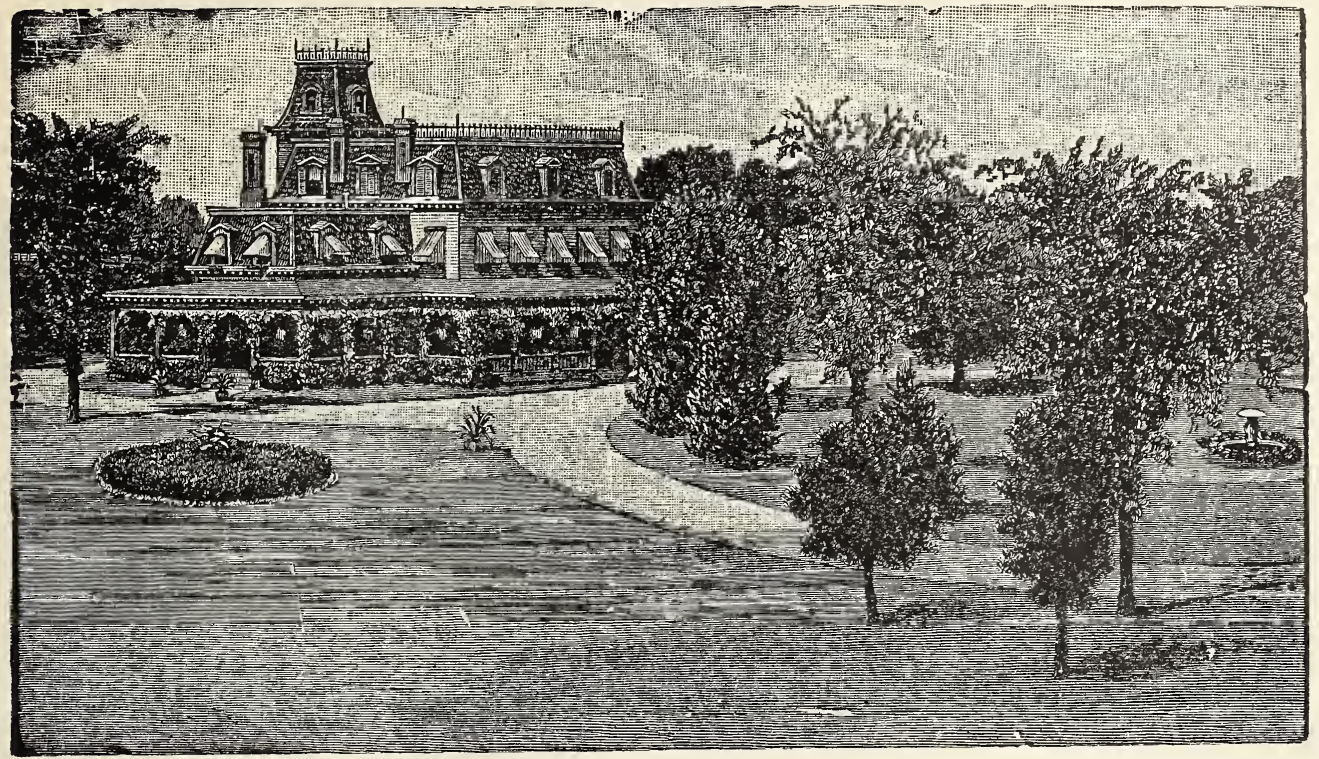

\section{VELVET GREEN LAWN GRASS MIXTURES}

Velvet Sod. A mixture of fine dwarf, close growing grasses, that will produce a neat, velvety lawn and permanent sod in a short time. Weight, about 25 pounds to the bushel. One pound will seed about 300 square feet;
80 to 100 pounds are required for an acre. 1 lb. $60 \mathrm{c} ; 3$ lbs. $\$ 1.70$. By Express, 5 lbs. and over, $40 \mathrm{c}$ per lb.

Shady Lawn. A modification of our famous Velvet Sod mixture, designed for use in shady places. Lb. 60c: 3 lbs. $\$ 1.70$. By Express, 5 lbs. and over, $40 \mathrm{c}$ per $\mathrm{lb}$.

\section{FLOWER SEEDS}

Ageratum. Excellent bor bouquets. Color, lavender, blue and white: Half hardy annuals. Mixed. Pkt. 10c.

Alyssum. The old-fashioned variety. Flowers pure white. Pkt. 10c. Aster. Finest double mixed. Pkt. 10c.

Asters. Red 10c, Pink 10c, White 10c, Lavender 10c.

Aquilegia Columbine. In all colors. Pkt. 10c.

Antirrhinum. (Snap Dragon.) The Antirrhinum, better known as the Snap Dragon, is of very easy culture. Sow in house in April, transplant in ground in May. Pkt. 10c.

Balsam. (Lady's Slipper, Touch-Me-Not.) An old favorite, producing gorgeous masses of beautiful, brilliant-colored flowers in the greatest profusion, double as roses and in every shade of color. Finest mixed. Pkt. 10c.

Calliopsis. A most brilliant hardy annual. The flowers on the outer edge are yellow, having a dark purple center. Pkt. 10c.

Campanula, Canterbury Bells. (Perennial.) In all colors. Pkt. 10c.

Candytuft. (Perennial.) Showy, hardy annuals, very useful for edgings and masses, excellent for cutting; continuous bloom from July to October. Pure white. Pkt. 10c.

Cardinal Climber. A splendid climber that has created a sensation wherever grown. It reaches from 20 to 30 feet. Clustered with red, $11 / 2$-inch flowers. Pkt. 15c.

Carnation. Giant Margaret. Known and praised for the richness and beauty of color and fragrance. Sow seed in the house. Half hardy. Finest double mixed. Pkt. 15c

Carnation. Double mixed. All shades and colors. Pkt. 15c.

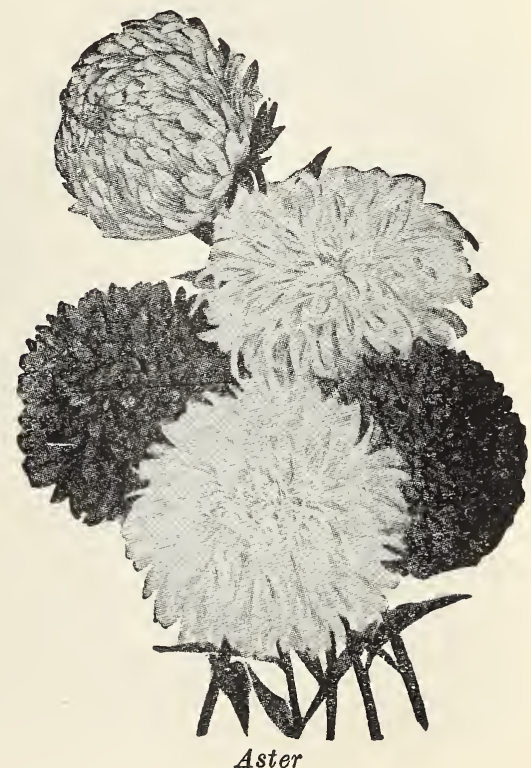

Aster 
Celosia (Cockscomb). Handsome garden and pot plants, bearing large combs of crimson, pink or golden striped color. Pkt. $10 \mathrm{c}$.

Centaurea (Bachelor's Button). A showy, hardy annual succeeding well in any soil, and bearing a profusion of flowers in shades of pink, blue and purple. Pkt. 10c.

Cosmos. Grows and blooms with the greatest freedom in any soil. Flowers dainty, of brilliant colors, carried on long, slender stems. Foliage feathery and very pretty. Extra fine for cut flowers. Finest mixed. Pkt. 10c.

Chrysanthemum. Mixed. All colors. Pkt. 10c.

Cobaea. A rapid growing climber with dark green foliage and blue-bell shaped flowers. Pkt. 10c.

Dahlias. Finest double flowers, including the new, large flowered varieties. One of the best autumn flowering plants. Half hardy perennial; 3 to 4 feet. Pkt. 15c.

Daisy, Shasta. A hardy perennial, bearing large, pure whi e flowers, sometimes four inches in diameter, in great profusion on long, stiff stems, fully two feet long. Excellent for cutting. Pkt. 10c.

Datura. Showy, large branching-plants, growing three to five feet high, bearing trumpet-shaped flowers six inches in length. Double mixed. Pkt. 10c.

Delphinium. (Larkspur.) Produces freely long, slender flower spikes of great beauty, four feet high. Double tall mixed. Pkt. 10 c.

Delphinium. (Perennial.) Hardy perennial plants with brilliant spikes. Double and single flowering mixed. Finest mixed. Pkt. 10c.

Eschscholtzia (California Poppy). Mixed many sorts. Pkt. 10c.

Forget-Me-Not (Myosotis). Neat and beautiful little plants with star-like flowers. Succeeds best in a moist situation. Pkt. 10c.

Four O'Clock (Mirabilis). Also called Mirabilis and Marvel of Peru. Well known free flowering garden favorite. Does well everywhere. Dwarf mixed. Pkt. 10c.

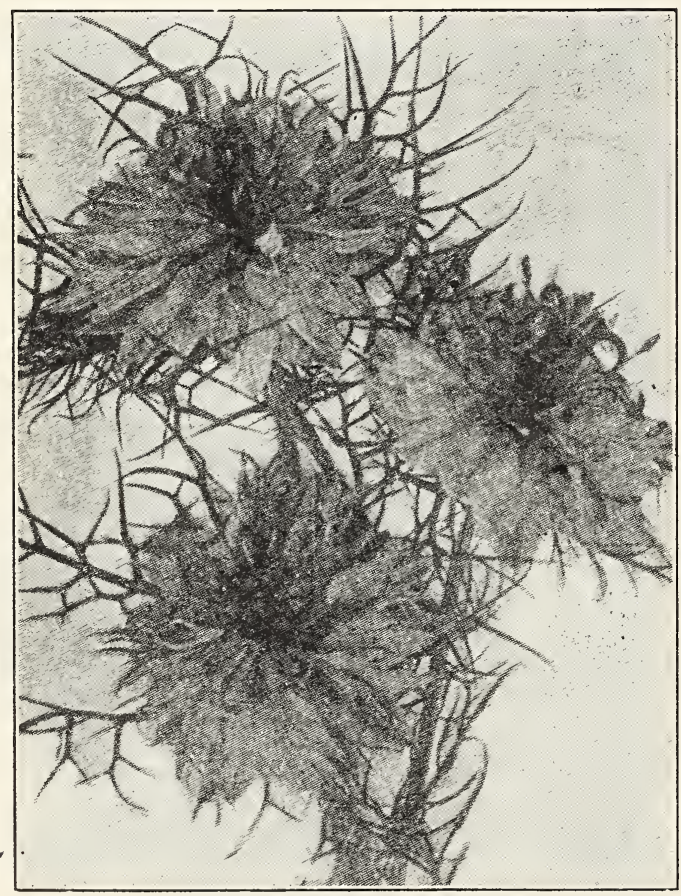

Nigella (Love in a Mist)

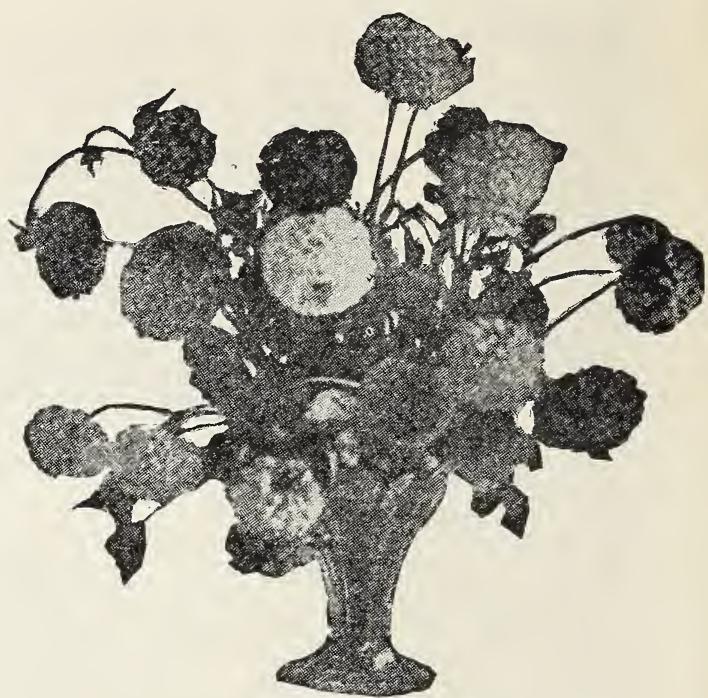

Annual Dahlia

Foxglove. (Digitalis.) Perennial. Exceedingly showy and ornamental plants of stately growth and varied colors. Hardy perennials. Fine mixed. Pkt. 10c.

Gaillardia. (Blanket Flower.) Perennial. One of the most showy and brilliant of garden flowers, fine for bedding and cutting, producing large flowers of rich shades throughout the summer. Pkt. 10c.

Gourds. (Ornamental.) Mixed. Fine assortment. Pkt. 10c.

Helichrysum. (Everlasting.) Straw flower. Large flower, double, finest mixed colors. Annual. One to two feet high. Double everlasting flowers, in shades of yellow, white, red, dark blue, etc. Pkt. 10c.

Hollyhocks (Perennial). All colors. Double mixed. Pkt. 10c.

Humulus (Climbing Hop). The well-known, fast-growing hardy climber; 15 to 20 feet. Pkt. 10c.

Kochia Trichophylla (Improved Summer Cypress). A rapid growing, hardy annual; foliage green, turning to fiery red in autumn: verv ornamental on the lawn: 2 to 3 feet in height. Pkt. 10c.

Lobelia. Flowers rich, deep blue; dark foliage; best for bedding. Pkt. 10c.

Marigold, Tail Tagates. French and African. Double mixed. Great variety of colors. A well known garden annual; 2 to 3 feet high. Large double flowers, orange, maroon, striped, etc. Pkt. 10c.

Ipomea Grandiflora. (Moonflower.) 25 to 30 feet. At night the plants are covered with large, pure white frag. rant flowers. Pkt. 10c.

Mingonette. A well known most fragrant little flower. Wants a sunny situaiion. Sow seeds in May where it is to remain. Pkt. 10c.

Morning Glory. A new giant type with enormous flowers, handsome colors, shapes and markings. Their colors run from snow white through, from the palest pink, all shades of biue and to darkest reds and purples. Finest mixtures. Pkt. 10c.

Nasturtium. Dwarf mixed. Pkt. 10c.

Nigella. (Love in a Mist.) Curious free flowering plants, have most interesting looking flowers. Will grow in any soil. Sow in open ground in May. Pkt. 10c.

Nasturtium. T'all or Climbing. Mixed. Pkt. 10c.

Pansies. In brilliancy and variety of color cannot be excelled. Sow seeds in February or March in shallow boxes in plants for canna or dahlia beds and single specimens. Mixed. Pkt. 10c. 
Phlox Drummondii (Flame Flower). A lovely strain of plants growing 1 to $1 \frac{1 / 2}{2}$ feet high, covered with a mass of bright flowers, excellent for pot plants and for bedding. Finest mixed. Pkt. 10c.

Poppy. Very rich in colors, large single and double flowers. Pkt. 10c.

Portulaca. Double rose flower mixed. A large percentage of the flowers will come perfectly double, of the most brilliant scarlet, crimson, white, yellow. Pkt. 10c.

Petunia Giant Ruffled. The flowers of this strain are ruffled and fringed; colors rich and gorgeous with deep throats of various shades. Fine mixed. Pkt. 20c.

Sunflower. Large, double, yellow flower. Pkt. 10c.

Sweet Peas. Beautiful, fragrant, free flowering, climbing plants. Plant seed two inches deep, early in spring; support by stakes. In all colors. Pkt. 10c.

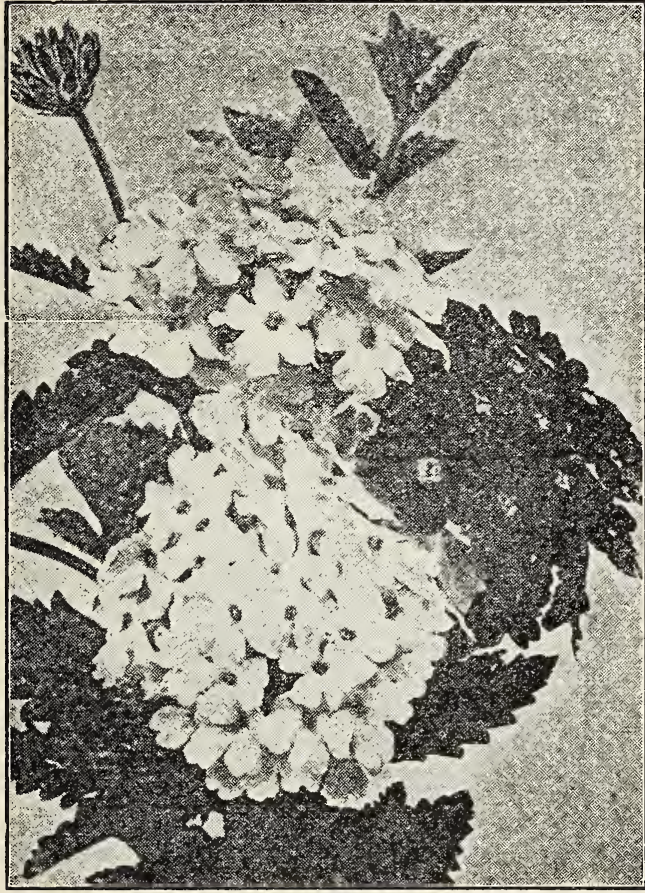

Verbena

SCABIOSA

(Mourning Bride or Sweet Scabiosa)

Handsome summer border plant, producing its splendid flowers in greatest profusion from July until severe autumn frosts. Flowers are of compact, rounded shape, long stems, making them ideal cut-flowers which keep in water a week. The colors are both strong and dainty, equally enjoyable and effective in bouquets or the garden. Hardy annual; 2 to $2 \frac{1 / 2}{2}$ feet. Double. All colors mixed. Pkt. 10c.

Stocks. (German Ten Weeks.) The Ten Weeks Stocks or Gilliflower is one of the most popular of our garden favorites; is good for massing, bedding or pot culture. Sow seed in house, transplant to pots: in June set out in open ground. Finest mixed. Pkt. 10c.

Wallflower (Cherianthus Cheiri). This is a favorite European garden flower. Sow , thinly in shallow drills in early spring. Colors yellow, brownish, purple, etc. Pkt. 15c.

Verbena. A mixture from the most beautiful named sorts, containing specimens of white, yellow and scarlet, with shadings and markings that are particularly beautiful. Pkt. 10c.

Verbena. Scarlet 10c, Violet Blue 10c, Pink 10c.

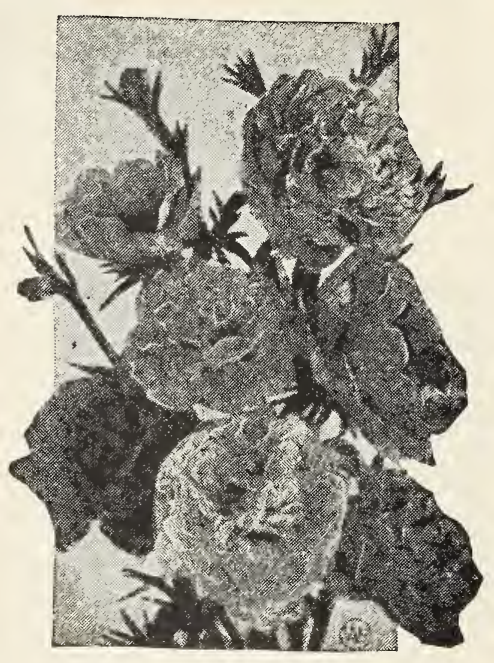

Portulaca

Sweet William (Hardy Perennial). Free flowering hardy perennial, producing a splendid effect in beds and borders with rich and varied flowers. Blooms June to September. $1 \frac{1 / 2}{2}$ feet high. Pkt. 10c.

Zinnia (Youth and Old Age). Strong growing, free flowering plant; flowers large, double, very fine colors. Especially fine for background. Double mixed. Pkt. 10c.

Zinnia Dahlia Flowers. This mammoth size, unusual shaped and color perfected type. Very clearly resembles the double decorative type dahlia in form and in their robust growth. Pkt. 15 c.

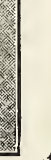

60
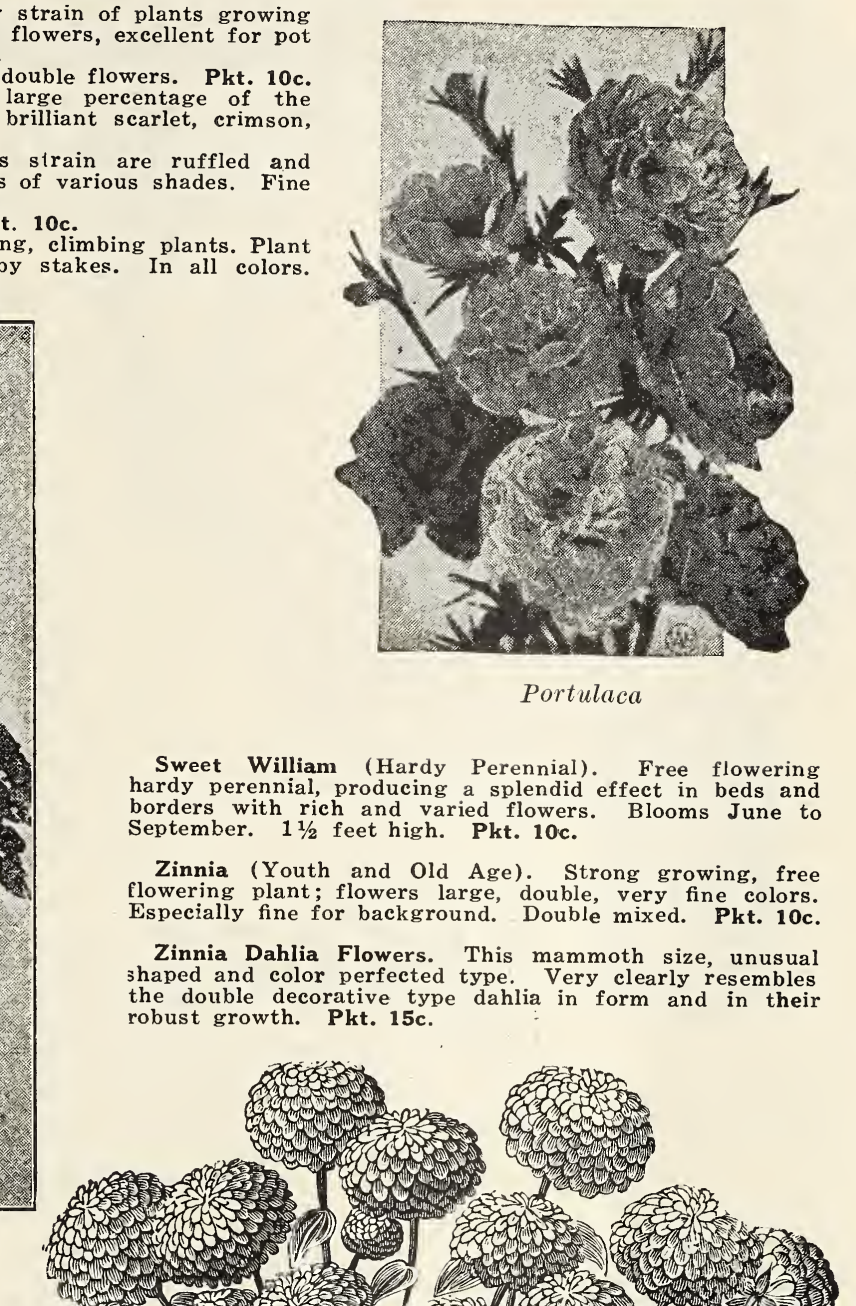


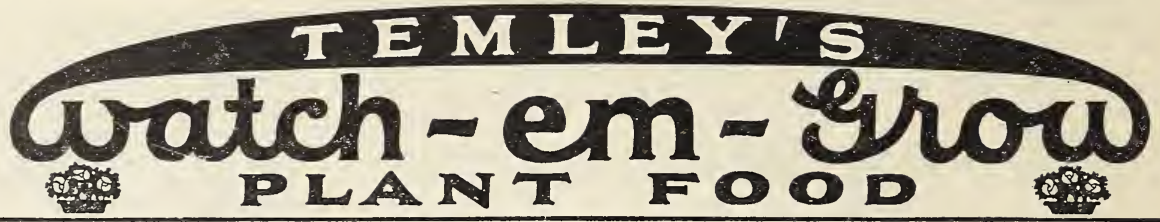

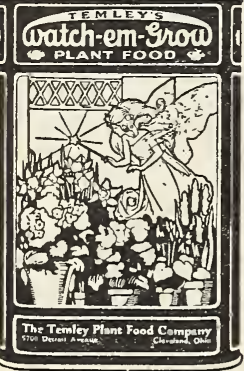

A wonderfully quick acting, perfectly compounded plant food, giving us one of the best balanced fertilizers possible to secure.

Use it on your house plants as follows: Dissolve a teaspoonful in a cup of hot water, afterwards pouring this into one gallon of cold water. Water your plants with this mixture. For a 6 -inch pot plant use a pint of mixture once each week, until you note improvement; then once in two weeks, and occasionally thereafter.

In the Garden it may be used in the same way as recommended for pot plants. A trial packet, 10 cents; a large $8 \mathrm{oz}$. can, 50c.

Dry Powdered Arsenate of Lead. Because of its unusual lightness, stays thoroughly in suspension during spraying operations, thus giving the spray uniform strength. It contains from 30 to 33 per cent arsenic oxide, thoroughly in combination with lead, and less than 1 per cent water soluble arsenic. This means that it has maximum killing power. $1 \mathrm{lb}$. 75c.

Liquid Bordeaux. Combined fungicide and insecticide;

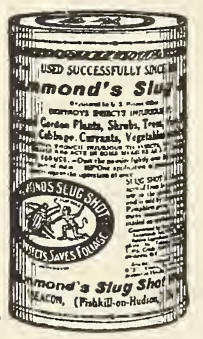
for fruit trees, potatoes, melons, cucumbers, ete.; also for mildew black spots on roses. Per $1 b .75$ c.

Slug Shot. Very effectual in destroying caterpillars, currant, gooseberry and cabbage worms; potato, melon, squash and cucumber bugs, rose slugs, etc. When used on squash, melon and cucumber vines should be put on lightly. $1 \mathrm{lb}$. 45c. By Express, 5 lbs. $\$ 1.50$.

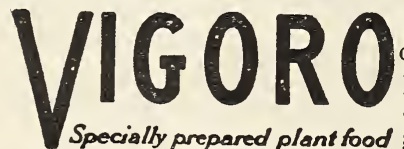

Scientifically balarreed and complete, VIGORO is a specially prepared plant food. It contains all of the elements necessary to

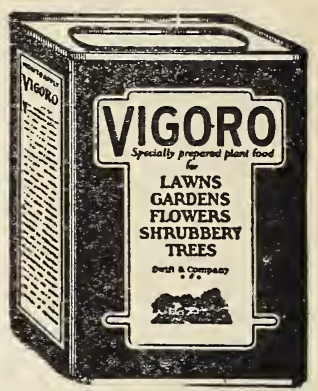

shrubbery and trees. The cost is only $10 \mathrm{e}$ to $20 \mathrm{c}$ for every 100 square feet. It is clean, odorless, easily sown by hand like grass seed. Complete directions in every bag. Price, Postpaid, 5 lbs., 50c; Express, 5 lbs., 75c; 25 lbs., $\$ 1.95$; 50 lbs., $\$ 3.00 ; 100$ lbs., $\$ 5.00$.

\section{INDEX}

\begin{tabular}{|c|c|c|c|c|c|}
\hline A & & 8 & Hydrar & & \\
\hline .. & bage $\ldots \ldots 46,47$ & entra $\quad \ldots \ldots \ldots$ & I & Oak & Ivia \\
\hline ... 34 & ium $\quad . . \ldots .33$ & Digitalis $\quad \ldots \ldots 29,62$ & nex & & cus \\
\hline $\begin{array}{l}\operatorname{um}_{\text {us }} \ldots \\
\ldots\end{array}$ & $\begin{array}{l}\text { lliearpa } \quad \ldots \\
\text { lliopsis }\end{array}$ & & Insecti & & $\begin{array}{l}\text { berr'y } \\
\text { chl }\end{array}$ \\
\hline$\ldots \ldots$ & alycanthus & & & yysandra & \\
\hline 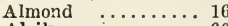 & 61 & & $J$ & 年 & - \\
\hline & $\mathrm{t}$ & noltzia & Spt & & \\
\hline & 33 & hus & 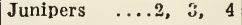 & & \\
\hline & Clin & eens & $\mathbf{K}$ & ps & erries \\
\hline .. & ion $\ldots .$. & 4 & & & Peas \\
\hline sis $\ldots$ & $8 \quad \ldots \ldots \ldots \ldots 47$ & $F$ & $\begin{array}{lll}\cdots & \ldots & 10 \\
\cdots & \ldots & 62\end{array}$ & $\mathrm{P}$ & nores \\
\hline inum $\ldots \ldots .61$ & $\ddot{\mathrm{er}}$ & zer & Kohlrabi & & \\
\hline$\ldots \ldots 36,37$ & . & $\lg$ & $\mathbf{L}$ & oniums. & \\
\hline & ..... & ne-no & ce & - & $T$ \\
\hline$a \quad \ldots$ & & & & $\mathbf{P}_{2}$ & anti \\
\hline ae $\cdots$ & $\ldots .12, \quad 38,39$ & I & $\mathrm{Ha}$ & $\mathrm{Pl}$ & $\mathrm{T}$ \\
\hline chia $\ldots \ldots .32$ & hemums 28,62 & elocl & $\begin{array}{l}\text { of the } r \\
\text { ns } \ldots \text {. }\end{array}$ & Pl & 1 \\
\hline$\ldots \ldots$ & $\ldots \ldots \ldots$ & Purpl & $\ldots$ & .. & \\
\hline agus $\quad \ldots$ & & & $\ldots \ldots \ldots 3$ & n. & Tree \\
\hline $\begin{array}{c}\text { Asters } \\
\text { Azalea }\end{array}$ & $\begin{array}{l}\text { iphylum } \ldots \\
\text { Seeds } \ldots . .\end{array}$ & Fun & $\mathbf{M}$ & y $\ldots$ & Turnips $\quad$ \\
\hline & .. & & & aca & \\
\hline th & ( & 2 & & & \\
\hline 年 & is & & 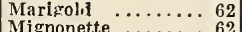 & $\mathrm{P}$ & $n$ \\
\hline rry $\ldots .33, \cdots 4$ & C & 3 & $M$ & $\mathrm{Pu}$ & ca \\
\hline & Co & erries & M & Quince & \\
\hline 45 , & aster & $G_{-1}$ & & & \\
\hline as & ers & Seeds & $M$ & & em-grow \\
\hline erries & $\begin{array}{l}\text { Cyrrants } \\
\text { Cydonia }\end{array}$ & Gypsophila & $M$ & $\mathbf{R}$ & Melon \\
\hline g Hear & D & 21 & & ons & $\begin{array}{l}\mathrm{a} \\
\mathrm{s}\end{array}$ \\
\hline & D & & & & is $\ldots \ldots \ldots$ \\
\hline $\begin{array}{l}\text { Corn } \\
\mathrm{Spr}\end{array}$ & Dai & $\mathrm{H}$ & Mustard & & $\ddot{i}$ \\
\hline ...... & um $\quad$. & & & 20,20 & ucca \\
\hline & odium & kles & & bekia ${ }_{\text {a-bagas }} \ldots \ldots \ldots$ & \\
\hline
\end{tabular}


